\title{
Loyaliteit en tevredenheid : een studie naar de relatie tussen merktrouw en consumententevredenheid
}

Citation for published version (APA):

Bloemer, J. M. M. (1993). Loyaliteit en tevredenheid : een studie naar de relatie tussen merktrouw en consumententevredenheid. [Doctoral Thesis, Maastricht University]. Datawyse / Universitaire Pers Maastricht. https://doi.org/10.26481/dis.19930519jb

Document status and date:

Published: 01/01/1993

DOI:

10.26481/dis.19930519jb

Document Version:

Publisher's PDF, also known as Version of record

\section{Please check the document version of this publication:}

- A submitted manuscript is the version of the article upon submission and before peer-review. There can be important differences between the submitted version and the official published version of record.

People interested in the research are advised to contact the author for the final version of the publication, or visit the DOI to the publisher's website.

- The final author version and the galley proof are versions of the publication after peer review.

- The final published version features the final layout of the paper including the volume, issue and page numbers.

Link to publication

\footnotetext{
General rights rights.

- You may freely distribute the URL identifying the publication in the public portal. please follow below link for the End User Agreement:

www.umlib.nl/taverne-license

Take down policy

If you believe that this document breaches copyright please contact us at:

repository@maastrichtuniversity.nl

providing details and we will investigate your claim.
}

Copyright and moral rights for the publications made accessible in the public portal are retained by the authors and/or other copyright owners and it is a condition of accessing publications that users recognise and abide by the legal requirements associated with these

- Users may download and print one copy of any publication from the public portal for the purpose of private study or research.

- You may not further distribute the material or use it for any profit-making activity or commercial gain

If the publication is distributed under the terms of Article $25 \mathrm{fa}$ of the Dutch Copyright Act, indicated by the "Taverne" license above, 
LOYALITEIT EN TEVREDENHEID 
두 1993, José Bloemer, Maastricht

CIP-GEGEVENS KONINKLIJKE BIBLIOTHEEK, DEN HAAG

Bloemer, Johanna Maria Mediatrix

Loyaliteit en tevredenheid : een studie naar de relatie tussen merktrouw en consumententevredenheid / Johanna

Maria Mediatrix Bloemer. - Maastricht : Universitaire

Pers Maastricht. - Ill.

Proefschrift Maastricht - Met lit. opg.

ISBN 90-5278-077-3

NUGI 686

Trefw.: consumentengedrag

Omslagontwerp: Mannita Butković

Boekverzorging: Datawyse I Universitaire Pers Maastricht 


\title{
LOYALITEIT EN TEVREDENHEID
}

\author{
Een studie naar de relatie tussen \\ merktrouw en consumententevredenheid
}

\begin{abstract}
PROEFSCHRIFT
ter verkrijging van de graad van doctor aan de Rijksuniversiteit Limburg, op gezag van de Rector Magnificus, Prof. mr. M.J. Cohen, volgens het besluit van het College van Dekanen, in het openbaar te verdedigen op woensdag, 19 mei 1993 om 16.00 uur

door

Johanna Maria Mediatrix Bloemer
\end{abstract}




\section{Promotores:}

Prof. dr. J.D.P. Kasper

Prof. dr. Th.B.C. Poiesz (Katholieke Universiteit Brabant)

\section{Beoordelingscommissie:}

Prof. dr. A. van Witteloostuijn (voorzitter)

Prof. dr. C. de Neubourg

Prof. dr. G.M. van Veldhoven (Katholieke Universiteit Brabant) 


\section{Voorwoord}

Begin 1988 werd begonnen met het schrijven van dit proefschrift. Een aantal jaren is er vervolgens aan gewerkt en voor u ligt het eindresultaat. Hoewel het voltooien van een proefschrift voor een deel een persoonlijke aangelegenheid is, is het onmogelijk haar geheel op eigen kracht te volbrengen. Aan al diegenen die in de loop der jaren op de één of andere wijze betrokken zijn geweest bij de verwezenlijking ervan, wil ik daarom, gaarne mijn oprechte dank uitspreken.

Dit geldt met name voor mijn beide promotoren prof. dr. Hans Kasper en prof. dr. Theo Poiesz. Beiden hebben, op een voor elk van hen karakteristieke wijze, een substantiële bijdrage geleverd aan de verwezenlijking van dit proefschrift. Zij hebben mij steeds met raad en daad ter zijde gestaan en steeds opnieuw aangezet om dit proefschrift verder te vervolmaken.

Daarnaast dank ik de leden van de beoordelingscommissie, die zo nauwgezet het manuscript hebben bestudeerd; prof. dr. Chris de Neubourg, prof. dr. Arjen van Witteloostuijn en in het bijzonder prof. dr. Gery van Veldhoven.

Alle collega's van de sectie Marketing wil ik danken voor hun morele steun en vertrouwen, waarbij ik met name wil noemen dr. Jos Lemmink. Zowel wetenschappelijk als persoonlijk wist hij meerdere malen een verhelderend licht op de verschillende aspecten van dit proefschrift te werpen.

Verder gaat mijn dank uit naar de student-assistenten die in de loop der tijd betrokken zijn geweest bij het onderzoek: Marilieke Engbers, Judith Laarman en Alwin Lin. Met name bij de operationalisatie van het onderzoek zijn zij voor mij van onvervangbare waarde geweest.

In de loop der tijd heb ik met een groot aantal mensen van gedachten mogen wisselen over het onderwerp van dit proefschrift. Deze mensen hebben mij van vele waardevolle adviezen voorzien. Graag wil ik met name noemen dr. Ton Kuylen en dr. Mia Stokmans, de leden van het netwerk bedrijfseconomie en de begeleidende hoogleraren.

Verder wil ik een woord van dank uitspreken aan al diegenen die de (lange) vragenlijst bij mijn onderzoek hebben ingevuld en diegenen die betrokken zijn geweest bij de uiteindelijke vormgeving van dit boek.

Tevens wil ik A.C. Nielsen (Nederland) B.V. en Centrum voor Marketing Analyse in dit verband danken voor hun bijdrage aan het tot stand komen van dit proefschrift.

Niet in de laatste plaats wil ik al diegenen bedanken die mij voortdurend en onvoorwaardelijk in mijn persoonlijke omgeving terzijde hebben gestaan. Met name wil ik noemen Hans te Kolsté, die mij steeds opnieuw met raad en daad ter zijde heeft gestaan en mijn moeder, die voortdurend heeft meegeleefd en altijd het volste vertrouwen in een positieve afronding heeft kenbaar gemaakt.

Tot slot wil ik dit boek opdragen aan papa voor wie deze promotie veel zou hebben betekent maar die haar helaas niet meer mag meemaken. 



\section{Inhoudsopgave}

Inleiding $\ldots \ldots \ldots \ldots \ldots \ldots \ldots \ldots \ldots \ldots \ldots \ldots \ldots \ldots \ldots \ldots$

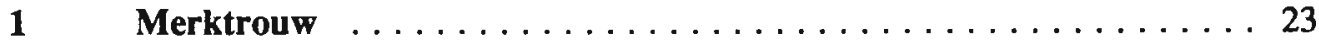

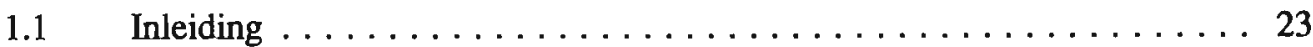

1.2 Conceptualisatie en afbakening van merktrouw $\ldots \ldots \ldots \ldots \ldots \ldots 24$

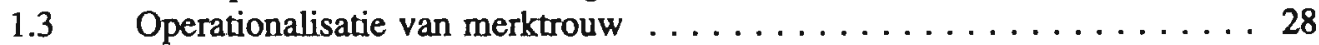

1.3.1 Verschillende benaderingen bij de operationalisatie van merktrouw . . . 28

1.3.2 Uitwerking en evaluatie van de deteministische (micro) benadering van merktrouw ........................ 30

1.3.3 Uitwerking en evaluatie van de stochastische (macro) benadering

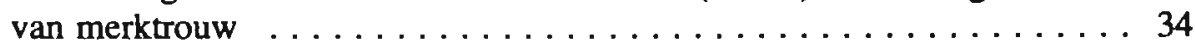

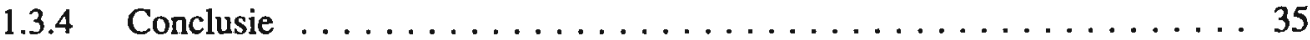

$1.4 \quad$ Alternatieve benadering van merktrouw $\ldots \ldots \ldots \ldots \ldots \ldots \ldots \ldots 36$

$1.5 \quad$ Verklaring van merktrouw $\ldots \ldots \ldots \ldots \ldots \ldots \ldots \ldots \ldots \ldots \ldots$

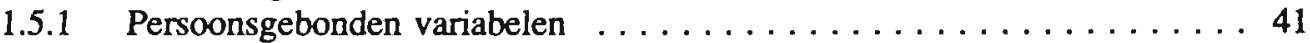

1.5.2 Aankoopvariabelen . . . . . . . . . . . . . . . . . . 49

1.5.3 Gebruiksvariabelen . . . . . . . . . . . . . . . . . . 49

1.5.4 Marktvariabelen ....................... 50

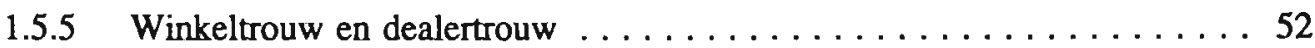

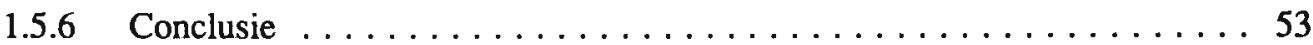

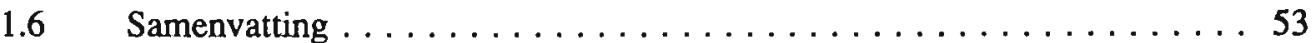

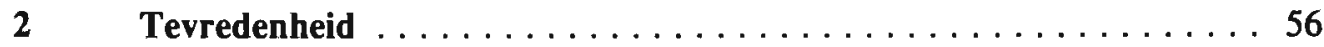

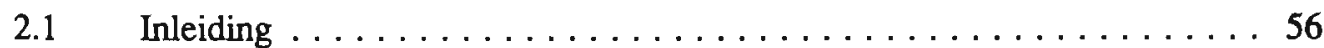

2.2 Tevredenheid: een economische benadering $\ldots \ldots \ldots \ldots \ldots \ldots 7$

2.3 Tevredenheid: een economisch-psychologische benadering . . . . . . 60

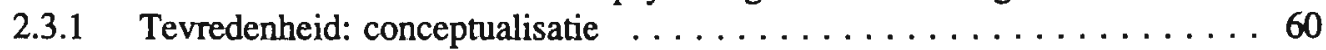

2.3.2 Two stage expectancy confirmation model $\ldots \ldots \ldots \ldots \ldots \ldots \ldots \ldots 6$

2.3.3 Verwachtingen over de produktprestatie $\ldots \ldots \ldots \ldots \ldots \ldots \ldots 6 . \ldots 6$

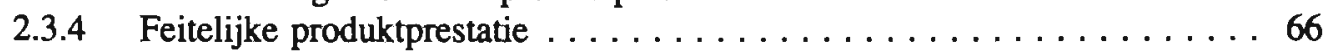

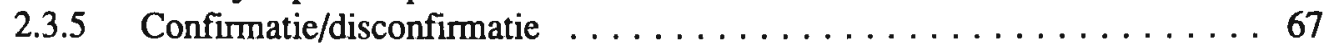

2.3.6 Subjectieve vergelijkingsprocessen $\ldots \ldots \ldots \ldots \ldots \ldots \ldots \ldots \ldots 6$

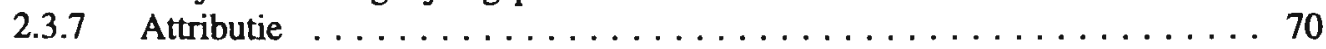

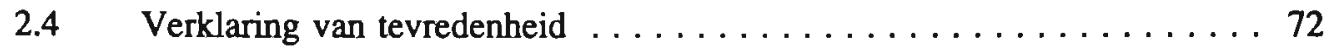

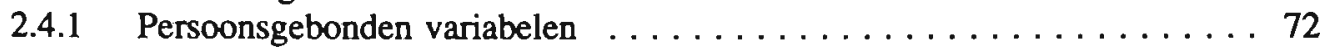




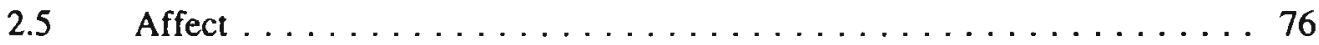

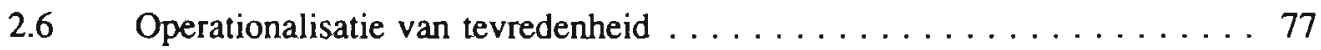

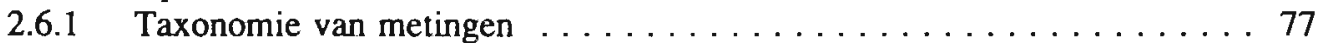

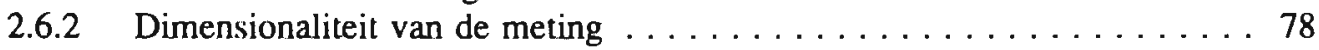

2.6.3 Specificiteit van de meting . . . . . . . . . . . . . . 79

2.6.4 Kanttekeningen bij het meten van tevredenheid . . . . . . . . . 79

$2.7 \quad$ Samenvatting . . . . . . . . . . . . . . . . 81

3 De relatie tussen merktrouw en tevredenheid . . . . . . . . . . . . 84

$3.1 \quad$ Merktrouw en tevredenheid: een eerste inzicht in de samenhang . . . . 31

3.2 Kanttekeningen bij merktrouw . . . . . . . . . . . . . 88

3.2.1 Definitie van ware merktrouw en een definitie van herhalingsaankopen . . 88

3.2.2 Continuüm voor herhalingsaankopen en ware merktrouw . . . . . . 90

3.2 .3 Commitment . . . . . . . . . . . . . . . . . . . . 91

3.3 Kanttekeningen bij tevredenheid: soorten tevredenheid . . . . . . . . 93

3.4 Merktrouw en tevredenheid: het definitieve model (Model I) . . . . . . 95

3.4.1 Alternatieve visie op de rol van tevredenheid bij de verklaring van ware merktrouw . . . . . . . . . . . . . . . . . 95

3.4.2 Model voor de verklaring van ware merktrouw . . . . . . . . . 97

$3.5 \quad$ Hypothesen . . . . . . . . . . . . . . . . . . . 98

3.6 Bestaand onderzoek naar merktrouw en tevredenheid in het licht van het definitieve model $\ldots \ldots \ldots \ldots \ldots \ldots \ldots \ldots \ldots \ldots$

4 Commitment, involvement en deliberatie . . . . . . . . . . 101

$4.1 \quad$ Commitment . . . . . . . . . . . . . . . . . . 101

4.1.1 Conceptualisatie van commitment $\ldots \ldots \ldots \ldots \ldots \ldots \ldots \ldots \ldots 10 \ldots \ldots$

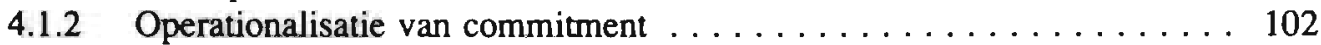

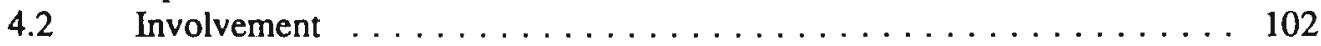

4.2.1 Conceptualisatie van involvement $\ldots \ldots \ldots \ldots \ldots \ldots \ldots \ldots \ldots . \ldots 102$

4.2.2 Antecedenten en consequenties van involvement . . . . . . . . 105

4.2.2a Antecedenten van involvement nader toegelicht . . . . . . . . . 106

4.2.2b Consequenties van involvement nader toegelicht . . . . . . . . . 107

4.2.3 Productinvolvement en merkkeuze-involvement . . . . . . . . . . . 109

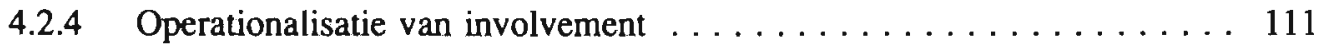

4.3 Afbakening van commitment en involvement ........... 111

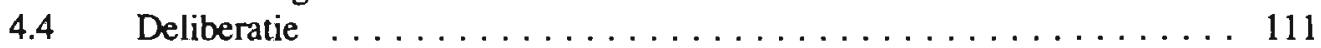

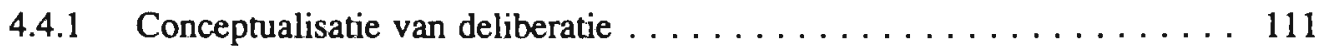

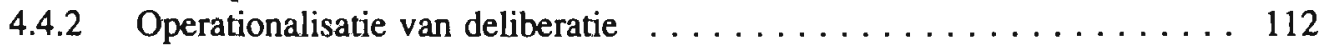

4.5 Elaboratie en het Elaboration Likelyhood Model . . . . . . . . . 112

$5 \quad$ Vooronderzoek . . . . . . . . . . . . . . . . . . . . 114

$5.1 \quad$ Doelstelling . . . . . . . . . . . . . . . . . . . . 114

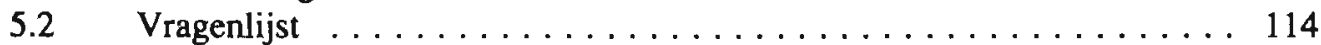

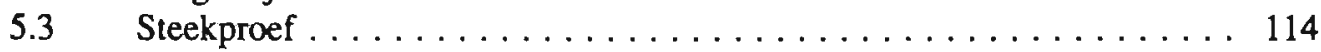

5.4 Schaalconstructie . . . . . . . . . . . . . . . . . . . 115

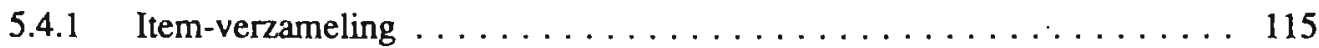


5.4.2 Item-selectie en betrouwbaarheid van de schalen . . . . . . . . 116

5.4 .3 Validiteit van de schalen . . . . . . . . . . . . . . . . . . 124

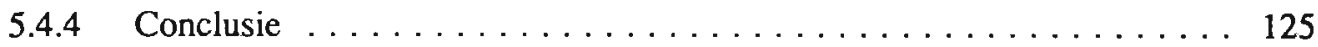

6 Opzet van het hoofdonderzoek en het profiel van de steekproef . . . 126

6.1 Doelstelling . . . . . . . . . . . . . . . . . . . . 126

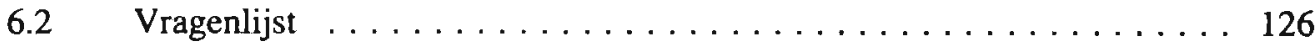

6.2.1 Verantwoording en beschrijving van de vragenlijst $\ldots \ldots \ldots \ldots 126$

6.3 Steekproef . . . . . . . . . . . . . . . . . . . . . . . 129

$6.4 \quad$ Achtergrondkenmerken van de steekproef . . . . . . . . . . . . . 129

6.4 .1 Cassettebandjes . . . . . . . . . . . . . . . . . . 131

6.4 .2 Haarshampoo . . . . . . . . . . . . . . . . . . . . . 131

6.4.3 Vergelijking tussen cassettebandjes en haarshampoo $\ldots \ldots \ldots \ldots 131$

6.5 Verantwoording en representativiteit van de steekproef $\ldots \ldots \ldots \ldots 131$

6.5 .1 Verantwoording van de steekproef . . . . . . . . . . . . 131

6.5.2 Representativiteit van de steekproef . . . . . . . . . . . . 133

6.5.2a Representativiteit ten opzichte van de achtergrondkenmerken . . . . . 134

6.5.2b Representativiteit ten opzichte van 'marktaandelen' van de gekochte merken . . . . . . . . . . . . . . . . . . . . . . 134

7 Eerste resultaten van het empirisch onderzoek: merktrouw en de mate van tevredenheid . . . . . . . . . . . . . . . . 135

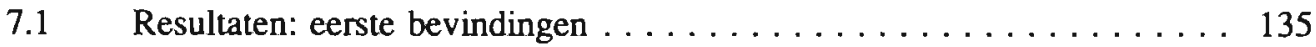

7.1.1 Merktrouw en de mate van tevredenheid ............... 136

7.1.2 Commitment, merkkeuze-involvement en deliberatie . . . . . . . . 138

7.1.3 Vergelijking tussen cassettebandjes en haarshampoo $\ldots \ldots \ldots \ldots \ldots 143$

7.1.4 Samenvatting van de belangrijkste totaalcijfers . . . . . . . . . 144

7.2 Eerste analyse van de relatie tussen merktrouw en de mate

7.2 .1 Cassettebandjes . . . . . . . . . . . . . . . . . . 147

7.2 .2 Haarshampoo . . . . . . . . . . . . . . . . . . . . . 148

7.2.3 Vergelijking tussen cassettebandjes en haarshampoo . . . . . . . . 149

7.2 .4 Samenvatting van de gevonden relaties . . . . . . . . . . . . 149

$7.3 \quad \begin{aligned} & \text { Nadere analyse van de relatie tussen merktrouw en de mate } \\ & \text { van tevredenheid } \ldots \ldots \ldots \ldots \ldots \ldots \ldots \ldots \ldots \ldots \ldots \ldots \ldots \ldots \ldots \ldots \ldots \ldots \ldots \ldots \ldots \ldots\end{aligned}$

7.3 .1 Cassettebandjes . . . . . . . . . . . . . . . . . . . . 150

7.3 .2 Haarshampoo . . . . . . . . . . . . . . . . . . . 153

7.3.3 Samenvatting van de belangrijkste gevonden relaties $\ldots \ldots \ldots \ldots 155$

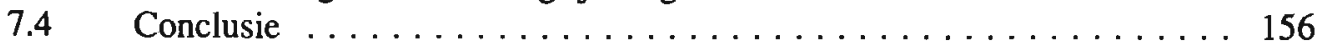

8 Nadere resultaten van het empirisch onderzoek:

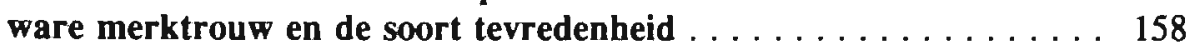

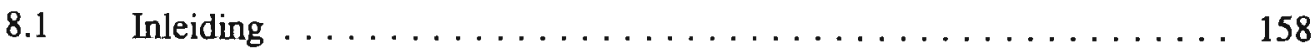

$8.2 \quad$ Manifeste en latente tevredenheid . . . . . . . . . . . . . . . . 159

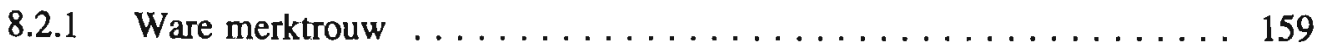


8.2.2 Alternatieve definitie en operationalisatie van ware merktrouw: loyaliteit (Model II) . . . . . . . . . . . . . . . . . . 165

$\begin{array}{lll}8.3 & \text { Conclusie } & 173\end{array}$

9 Conclusies en implicaties van het onderzoek . . . . . . . . . . 174

$9.1 \quad$ Conclusies . . . . . . . . . . . . . . . . . . . . . . 174

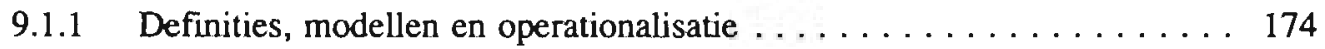

9.1.2 Hypothesen . . . . . . . . . . . . . . . . . . . 175

9.1.3 Terug naar de probleemstelling en de doelstelling . . . . . . . . 175

9.2 Aanbevelingen . . . . . . . . . . . . . . . . . . 177

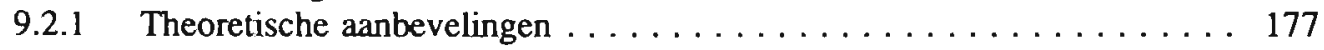

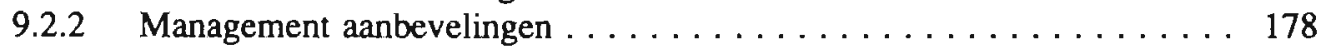

9.3 Beperkingen van het onderzoek . . . . . . . . . . . . . 182

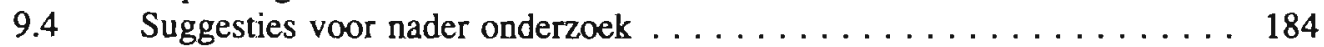

\section{Bijlagen:}

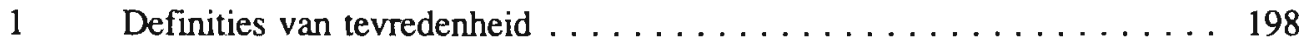

2 Definities van involvement ................... 200

3 Items Likert-schaal voor het meten van commitment . . . . . . . . . 201

4 Items Likert-schaal voor het meten van merkkeuze-involvement . . . . 202

5 Items semantische differentiaal voor het meten van involvement . . . . 205

6 Correlatie-analyse van commitment-, merkkeuze-involvement- en deliberatie-items (vooronderzoek) $\ldots \ldots \ldots \ldots \ldots \ldots \ldots \ldots . \ldots \ldots$

$7 \quad$ Factoranalyse merkkeuze-involvement (Likert-schaal) $\ldots \ldots \ldots \ldots 211$

8 Factoranalyse merkkeuze-involvement (semantische differentiaal) . . . . 213

$9 \quad$ Factoranalyse alle items (Likert-schalen) . . . . . . . . . . . 216

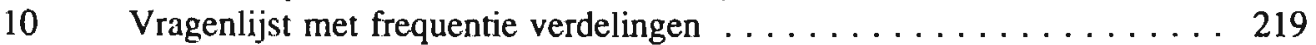

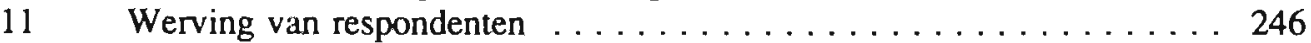

11.1 De advertentie . . . . . . . . . . . . . . . . . . . . 246

11.2 Het artikel in De Limburger van 26 februari $1992 \ldots \ldots \ldots \ldots . \ldots 247$

11.3 Artikel 'van eigen hand' . . . . . . . . . . . . . . . . . . . 248

12 Correlatie-analyse van commitment-, merkkeuze-involvement- en deliberatie-items (hoofdonderzoek) . . . . . . . . . . . . . . 249

13 Factoranalyse commitment, involvement en deliberatie . . . . . . . 251

14 t-toetsen voor het verschil in gemiddelde scores voor de twee produkten 253

$15 \chi^{2}$-toets voor het verschil voor wat betreft de samenstelling van de evoked set en de manier van heraankopen . . . . . . . . . 254

16 Relatie tussen de zevenpunts- en de procentschaal voor het meten van tevredenheid ........................ 255

$17 \quad$ Kruistabellen . . . . . . . . . . . . . . . . . . . . 257

Literatuur $\ldots \ldots \ldots \ldots \ldots \ldots \ldots \ldots \ldots \ldots \ldots \ldots \ldots \ldots \ldots \ldots \ldots$

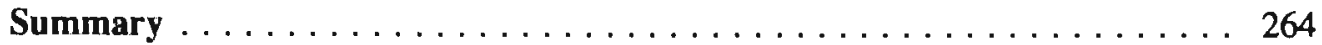

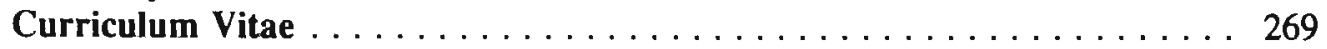




\section{Inleiding}

\section{Het belang van merktrouw}

Merktrouw is van groot belang voor iedere aanbieder van merkprodukten (goederen en diensten). Een aanbieder ontleent zijn bestaansrecht mede aan de merktrouw van consumenten. Merktrouw zorgt er namelijk voor dat consumenten een merk herhaald kopen. Geen enkele aanbieder zal zijn continuïteit gegarandeerd zien wanneer consumenten niet overgaan tot het herhaald kopen van een merk.

Behalve dat het voor de continuïteit van een onderneming noodzakelijk is dat consumenten produkten herhaald kopen, zijn herhalingsaankopen eveneens van belang voor de marketingkosten; deze kosten zijn immers veelal lager voor het houden van bestaande consumenten dan voor het krijgen van nieuwe consumenten (Aaker, 1991).

'Ware merktrouw' is meer dan alleen het herhaald kopen van een merk. Ware merktrouw zorgt er voor dat consumenten willen vasthouden aan hun merkkeuze en er belang bij hebben hetzelfde merk opnieuw te kopen. Dit brengt ons op het essentiële onderscheid tussen ware merktrouw en herhalingsaankopen. Herhalingsaankopen zijn het herhaald kopen van een merk waarbij de consument niet persé hoeft vast te houden aan zijn/haar merkkeuze. Ware merktrouw is daarentegen het herhaald kopen van een merk waarbij de consument het belangrijk vindt hetzelfde merk opnieuw te kopen en persé wil vasthouden aan het merk van zijn/haar keuze. Ware merktrouwe consumenten zijn daardoor minder gemakkelijk over te halen tot het wisselen van merk dan herhalingsaankopers.

De aanbieder van een produkt is, wanneer veel van zijn consumenten waarlijk merktrouw zijn, in zekere mate gegarandeerd van omzet. Veranderingen in de communicatie-, promotie-, prijs-, produkt- of distributiestrategie van de concurrent zullen ware merktrouwe consumenten minder eenvoudig overhalen van merk te wisselen dan herhalingsaankopers. Een waarlijk merktrouwe consument is daarnaast minder gevoelig voor bijvoorbeeld prijsverhogingen van het eigen produkt en zal minder snel van merk wisselen wanneer er incidenteel sprake is van ontevredenheid.

Herhalingsaankopers zijn daarentegen gemakkelijk te beïnvloeden in hun keuzegedrag door de concurrent en zijn zeer gevoelig voor negatieve ervaringen met het merk: zij wisselen gemakkelijker van merk.

Bovendien is, voor merken met een grote trouwe aanhang, de plaats in het schap min of meer gegarandeerd; is het gemakkelijker om nieuwe consumenten aan te trekken en is de tijd die het merk heeft om te reageren op 'bedreigingen' van de concurrentie langer, in vergelijking met merken zonder een trouwe aanhang (Aaker, 1991). 
De consument die waarlijk trouw is aan een merk vereenvoudigt en vergemakkelijkt hiermee de keuze uit de vele aangeboden merken. Deze consument hoeft niet elke keer opnieuw na te denken over welk merk gekocht wordt. Uit ervaring weet deze consument precies wat verwacht kan worden van het merk waaraan hij/zij trouw is; het aankooprisico wordt hierdoor tot een minimum beperkt. Merktrouw biedt een oplossing voor het steeds groter wordende probleem van veel consumenten: het helpt bij het maken van een keuze uit het vaak overweldigende aanbod van merken.

\section{Het belang van tevredenheid}

Iedere aanbieder van een produkt hecht belang (of zou, tenminste vanuit de marketingfilosofie belang moeten hechten) aan de tevredenheid van de consument. Hierbij wordt dan veelal uitgegaan van de vooronderstelling dat de kans dat een tevreden consument een merk opnieuw zal kopen, groter is dan de kans dat een niet tevreden consument een merk opnieuw zal kopen.

De consument streeft naar tevredenheid, omdat tevredenheid positief wordt ervaren. Het maakt daarbij niet uit of tevredenheid wordt opgevat als nut, als een cognitie, als een emotie of als de uitkomst van een vergelijkingsproces. Tevredenheid is voor de consument ook het bewijs dat hij/zij capabel is om een goede keuze uit het produktaanbod te maken. Bovendien streeft iedere consument ernaar zijn/haar behoeften te vervullen. Tevredenheid is tevens een bewijs dat een behoefte is vervuld.

Over het algemeen wordt van de vooronderstelling uitgegaan dat de tevredenheid met een merk een rol speelt bij merktrouw. Echter, voor zover bekend is de betekenis van tevredenheid voor merktrouw nooit uitgebreid en wetenschappelijk onderzocht. Het mag een open deur lijken, maar niet alle tevreden consumenten zijn trouw en zelfs niet alle ontevreden consumenten zijn ontrouw. Tot nu toe is nog weinig bekend over de aan merktrouw ten grondslag liggende processen.

Tevreden consumenten kunnen immers ook een ander merk gaan kopen, bijvoorbeeld omdat:

- zij gewoon eens iets anders willen proberen;

- een ander merk gemakkelijker verkrijgbaar is;

- het eigen merk niet verkrijgbaar is;

- een ander merk in de aanbieding is.

Ontevreden consumenten kunnen een bepaalde tijd hetzelfde 'probleemmerk' toch blijven kopen bijvoorbeeld omdat:

- er geen andere merken van het produkt verkrijgbaar zijn;

- het kopen van een ander merk te veel inspanning kost (financieel, fysiek, psychologisch of sociaal) omdat bijvoorbeeld bij de consument het gevoel heerst dat andere merken niet echt verschillend zijn; zij niet nog eens over de merkkeuze willen nadenken; of dat geen ander merk wordt aangeboden in de winkel die wordt bezocht. 
Het is voor een aanbieder relevant te weten waarom bijvoorbeeld een aantal tevreden consumenten een ander produkt gaat kopen dan wel waarom tevreden consumenten merktrouw zijn. Is tevredenheid een factor die merktrouw (mede) bepaalt?

\section{Probleemstelling en afbakening}

\section{Probleemstelling}

Voor zover er een verband tussen ware merktrouw en tevredenheid is gevonden, is dit verband niet perfect. Dit zal worden veroorzaakt door het feit dat nog andere variabelen deze relatie beïnvloeden en bijdragen aan de verklaring van ware merktrouw.

Het is belangrijk te onderzoeken hoe de relatie tussen ware merktrouw en tevredenheid er uit ziet. Aangezien tevredenheid niet de enige variabele zal zijn die bijdraagt aan de verklaring van ware merktrouw, is het tevens van belang na te gaan welke rol tevredenheid speelt in de relatie tot andere verklarende variabelen van ware merktrouw.

De doelstelling van het onderzoek is inzicht te krijgen in de verklaring van ware merktrouw en daarbij vast te stellen welke rol tevredenheid, eventueel in relatie tot andere factoren speelt, bij die verklaring.

De centrale probleemstelling luidt derhalve:

\section{Welke rol speelt tevredenheid bij de verklaring van ware merktrouw?}

Deze probleemstelling wordt bij de presentatie van de werkwijze nader toegelicht. Het is echter allereerst noodzakelijk het veld van onderzoek af te bakenen; dan komt de probleemstelling in het juiste kader te staan.

\section{Afbakening}

Voor het onderzoek naar de rol van tevredenheid bij de verklaring van ware merktrouw gelden de volgende beperkingen:

Met het onderzoek wordt getracht een verklaring te vinden voor ware merktrouw; niet voor herhalingsaankopen. Ware merktrouw is het opnieuw kopen van een merk met als basis de commitment aan dat merk. Herhalingsaankopen zijn eveneens het opnieuw kopen van een merk maar zonder dat deze op commitment aan dat merk zijn gebaseerd. De implicaties van ware merktrouw zijn zowel voor de consument als voor de aanbieder verschillend, ondanks het feit dat het feitelijk observeerbare gedrag identiek is (= het opnieuw aanschaffen van hetzelfde merk).

Merkontrouw en 'variety seeking' betreffen het niet opnieuw kopen van een merk en worden in dit onderzoek buiten beschouwing gelaten. Aan deze vormen van koopgedrag liggen andere antecedenten ten grondslag dan aan merktrouw. Bovendien hebben zij ook verschillende consequenties voor zowel de aanbieder als de consument. Merktrouw en 
merkontrouw worden door ons derhalve niet als twee uiteinden van één continuüm gezien. Maar merktrouw en merkontrouw worden als twee verschillende concepten beschouwd. Het verklaren van ontrouw hoort nadrukkelijk niet tot de probleemstelling. Wij plaatsen daarentegen ware merktrouw en herhalingsaankopen op een continuüm van 'opnieuw hetzelfde kopen'.

In het onderzoek wordt tevens geen aandacht besteed aan ontevredenheid. Ontevredenheid en tevredenheid verschillen in onze optiek zodanig fundamenteel dat zij ook niet de uiteinden van een continuüm vormen (zie tevens Herzberg, 1959). De antecedenten van ontevredenheid verschillen van die van tevredenheid en tevens zijn de consequenties van ontevredenheid, voor zowel de aanbieder als de consument, verschillend. Ontevredenheid zal eerder aanleiding geven tot ontrouw of variety seeking. De manier waarop uitdrukking wordt gegeven aan ontevredenheid behoort nadrukkelijk niet tot de probleemstelling.

In het onderzoek wordt voorts geen aandacht besteed aan het fenomeen multimerkentrouw. Zoals nog uit het literatuuroverzicht zal blijken, kunnen consumenten trouw zijn aan meerdere merken tegelijkertijd. Deze trouw aan meerdere merken tegelijkertijd kan echter ook worden opgevat als ontrouw ten opzichte van één merk in het bijzonder. Daarom en gezien de extra complicaties die de expliciete bestudering van multimerkentrouw voor ons onderzoek zou meebrengen, wordt hiervan afgezien.

Bij de verklaring van ware merktrouw kan gekozen worden uit een economische benadering en een economisch-psychologische benadering. Wij gaan, bij de verklaring van ware merktrouw, uit van een economisch-psychologische benadering. Dit betekent dat ware merktrouw wordt verklaard door psychologische variabelen en tevens dat ware merktrouw wordt gedefinieerd als een economisch-psychologisch concept.

Er wordt in het onderzoek niet expliciet aandacht besteed aan de meer (bedrijfs-)economische variabelen die bijdragen aan de verklaring van ware merktrouw. (Te denken valt hierbij aan de invloed van prijsveranderingen, de inzet van verschillende promoties, de distributiespreiding en overige micro- en macro-economische kenmerken van de markt zoals marktvormen, mobiliteitsbelemmeringen, 'switching costs' en strategische groepen.) Die (bedrijfs-)economische factoren zijn in andere studies over merktrouw wel aan de orde gekomen. Dan werd echter geen expliciete aandacht besteed aan de factor tevredenheid. Vandaar dat wij ons nu op die factor richten. Daarbij realiseren wij ons dat dit een partiële analyse is. In vervolgonderzoek zou simultaan met zowel economische als psychologische factoren rekening kunnen worden gehouden.

\section{Werkwijze}

In het vervolg van dit hoofdstuk zal een overzicht worden gegeven van de verschillende fasen van het onderzoek. De verschillende gehanteerde concepten zullen worden geïntroduceerd en gedefinieerd. Twee, met elkaar rivaliserende, onderzoeksmodellen (Model I en Model II) zullen kort worden toegelicht en er zal worden aangetoond dat het onderzoek een aantal a priori niet veronderstelde inzichten oplevert. 
Om een antwoord te kunnen geven op de vraag "welke rol speelt tevredenheid bij de verklaring van ware merktrouw?" worden in de loop van het onderzoeksproces twee verschillende modellen getoetst. Deze modellen verschillen van elkaar omdat er verschillende definities van ware merktrouw aan ten grondslag liggen. Model I is gebaseerd op de aanvankelijke definitie van ware merktrouw. Hierin is commitment een noodzakelijke voorwaarde voor ware merktrouw; commitment en ware merktrouw worden opgevat als twee separate concepten. Model $\Pi$ is gebaseerd op een alternatieve en aangepaste definitie van ware merktrouw. Commitment wordt dan wel opgenomen in de definitie van ware merktrouw. Daardoor kunnen commitment en ware merktrouw niet langer los van elkaar beschouwd worden.

Model I wordt in hoofdstuk 3 met bijbehorende hypothesen geformuleerd en toegelicht. Dit model is gebaseerd op de bevindingen van de literatuurstudie ten aanzien van merktrouw (hoofdstuk 1) en tevredenheid (hoofdstuk 2).

Het algemene Model I ziet er als volgt uit (Figuur A):

Figuur A: Algemeen Model I van de relatie tussen merktrouw en tevredenheid

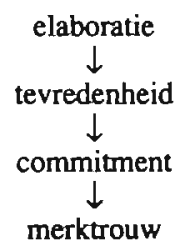

Model I laat zien dat elaboratie, tevredenheid, commitment en merktrouw concepten zijn die in het onderzoek centraal staan. Onderstaand zullen deze concepten allereerst kort worden toegelicht en gedefinieerd om vervolgens een meer specifiek Model I te kunnen presenteren. Dit specifieke model zal met behulp van het empirische hoofdonderzoek worden getoetst. Mede omdat de resultaten verkregen met Model I in meerdere opzichten niet bevredigend zijn, wordt Model II geformuleerd. Hierover later meer.

$\mathrm{Bij}$ het onderzoek naar de relatie tussen merktrouw en tevredenheid wordt er van uitgegaan dat het noodzakelijk is twee soorten merktrouw te onderscheiden: ware merktrouw en herhalingsaankopen.

Ware merktrouw is het herhaald aankopen van een merk waaraan commitment bij het merk ten grondslag ligt. Ware merktrouw wordt gedefinieerd als "the biased (i.e. nonrandom) behavioral response (i.e purchase), expressed over time, by some decision making unit, with respect to one or more altemative brands out of a set of such brands, and is a function of psychological (decision making, evaluative) processes".

Een herhalingsaankoop is het herhaald aankopen van een merk zonder dat dit op commitment bij het merk is gebaseerd. Herhalingsaankopen zijn gebaseerd op inertia (simpele keuze-heuristieken). Herhalingsaankopen worden gedefinieerd als "the biased (i.e. nonrandom) behavioral response (i.e purchase), expressed over time, by some decision making unit, with respect to one or more alternative brands out of a set of such brands, and is a function of inertia". 
Het onderscheid tussen ware merktrouw en herhalingsaankopen wordt in hoofdstuk 1 en hoofdstuk 3 nader uitgewerkt en toegelicht.

Ware merktrouw en herhalingsaankopen uiten zich beide in het opnieuw kopen van een merk. De oorzaak van dat deze aankopen verschilt echter wezenlijk. Het opnieuw aanschaffen van hetzelfde merk kan gebaseerd zijn op commitment of op inertia. Hierbij gaat het niet om een alles of niets situatie. De mate van commitment bij een merk kan variëren. Ware merktrouw en herhalingsaankopen kunnen daarom op één continuüm (Figuur B) worden geplaatst. Dit continuüm varieert van ware merktrouw gebaseerd op een (theoretisch) oneindige mate van commitment en herhalingsaankopen gebaseerd op geen enkele commitment maar op inertia (zie tevens hoofdstuk 3).

Figuur B: Het continuüm van herhalingsaankopen tot ware merktrouw

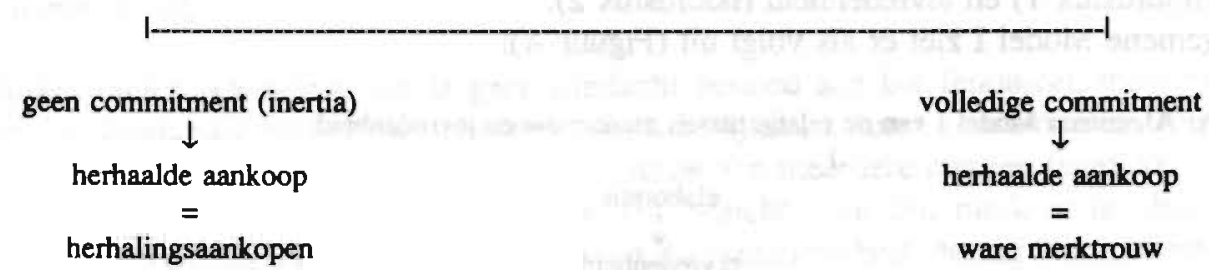

Commitment is een noodzakelijke voorwaarde voor ware merktrouw en is daarom als afhankelijke variabele in Model I opgenomen. De mate van commitment wordt gedefiniëerd als "de mate waarin een subject nadrukkelijk wil vasthouden aan de merkkeuze in een niet nader omschreven, toekomstige koopsituatie" (hoofdstuk 3).

Tevredenheid wordt door ons opgevat als "de uitkomst van een subjectieve evaluatie of het gekozen alternatief (=produkt/merk) overeenkomt met de verwachtingen van een subject over dat altematief, of deze overtreft". Het concept tevredenheid wordt uitgebreid besproken in hoofdstuk 2 .

Elaboratie is een concept dat het mogelijk maakt een onderscheid aan te brengen tussen twee verschillende soorten tevredenheid die van belang blijken te zijn: manifeste tevredenheid en latente tevredenheid. Elaboratie wordt gedefinieerd als "issue relevant thinking".

Een consument kan een merk op twee manieren evalueren; hij/zij kan de merkkeuze uitgebreid en expliciet evalueren maar hij/zij kan de merkkeuze ook niet of nauwelijks (en dus impliciet) evalueren. Om een merk uitgebreid en expliciet te evalueren (veel elaboratie over de merkkeuze) dient een consument over voldoende motivatie en capaciteit te beschikken. Beschikt een consument niet over voldoende motivatie en/of capaciteit dan zal hij/zij een merk niet uitgebreid en expliciet (willen/kunnen) evalueren (weinig tot geen elaboratie over de merkkeuze). Is een tevredenheidsoordeel gebaseerd op een uitgebreide en expliciete evaluatie van een merk dan spreken wij van manifeste tevredenheid. Is een tevredenheidsoordeel daarentegen slechts impliciet dan spreken wij van latente tevredenheid (meer hierover in hoofdstuk 3). 
Dit onderscheid tussen manifeste en latente tevredenheid is van groot belang omdat de consequenties van beide soorten tevredenheid van elkaar zullen verschillen. Manifeste tevredenheid is een expliciet, weloverwogen tevredenheidsoordeel en zal daarom direct en eenduidig van invloed zijn op het koopgedrag ten aanzien van het geëvalueerde merk in de toekomst. Latente tevredenheid is slechts de impliciete acceptatie van een merk en zal daarom niet zo direct en eenduidig van invloed zijn op het koopgedrag ten aanzien van het geëvalueerde merk in de toekomst. Concreet verwachten wij dat manifeste tevredenheid zal leiden tot commitment en ware merktrouw terwijl latente tevredenheid hooguit zal leiden tot herhalingsaankopen. Het algemene model uit Figuur B moet derhalve nader worden gespecificeerd voor deze twee situaties (zie Figuur C):

Figuur C: Model I gespecificeerd voor de relatie tussen herhalingsaankopen en latente tevredenheid en voor de relatie tussen ware merktrouw en manifeste tevredenheid.

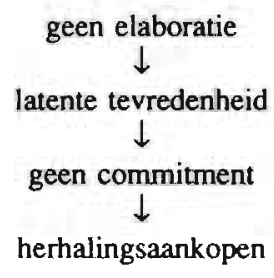

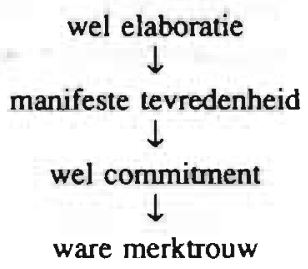

Aan dit model ligt een aantal hypothesen ten grondslag. De belangrijkste zijn dat manifeste tevredenheid zal leiden tot commitment en commitment zal leiden tot ware merktrouw. Deze hypothesen zijn gebaseerd op de assumptie dat naarmate de elaboratie toeneemt, de tevredenheid meer manifest is.

In het empirische hoofdonderzoek wordt (gegeven de probleemstelling en de hypothesen) met name aandacht besteed aan de relatie tussen manifeste tevredenheid en de mate van ware merktrouw. Om deze relatie in de empirie te kunnen onderzoeken moeten de in het voorgaande gedefiniëerde concepten uit Model I nog worden geoperationaliseerd.

Tevredenheid wordt geoperationaliseerd als de mate van tevredenheid, in termen van "voor hoeveel procent bent u tevreden met ...?" (zie tevens hoofdstuk 2 en hoofdstuk 6).

De soort tevredenheid, manifest of latent is afhankelijk van de mate van elaboratie. De mate van elaboratie kan worden geoperationaliseerd door gebruik te maken van de indicatoren van elaboratie: de motivatie en de capaciteit om de merkkeuze te evalueren (dit zijn tevens de noodzakelijke voorwaarden voor elaboratie). De motivatie om de merkkeuze te evalueren wordt geoperationaliseerd als merkkeuze-involvement en de capaciteit om de merkkeuze te evalueren wordt geoperationaliseerd als deliberatie. De concepten involvement en deliberatie worden, evenals commitment, in hoofdstuk 4 nader toegelicht.

Omdat er geen Nederlandse, valide en betrouwbaar bevonden, schalen voor handen zijn voor het met meten van merkkeuze-involvement, deliberatie en commitment worden deze schalen in het vooronderzoek door ons ontwikkeld. Dit is gebeurd op basis van in 
twee verschillende schalen voor het meten van merkkeuze-involvement te ontwerpen omdat merkkeuze-involvement in de literatuur zowel met een semantische differentiaal als met een Likert-schaal worden gemeten. Het gebruik van een semantische differentiaal voor het meten van merkkeuze-involvement blijkt echter onverwachte problemen op te leveren. Hierdoor moeten wij af zien van verdere toepassingen van deze schaal. Wel wordt een voldoende valide en betrouwbare Likert-schaal voor het meten van merkkeuze-involvement ontwikkeld. Tevens worden in het vooronderzoek betrouwbare en valide (Likert-)schalen voor het meten van zowel deliberatie als commitment ontwikkeld (hiervoor wordt verwezen naar de beschrijving van het vooronderzoek in hoofdstuk 5).

Ware merktrouw door ons geoperationaliseerd als de mate van ware merktrouw welke gebaseerd is op een omschrijving van de manier waarop een merk herhaald wordt aangekocht. (U heeft bij de eerst aankoop indertijd heel bewust voor dit merk gekozen. U heeft goed over uw keuze nagedacht. Het is voor u belangrijk om steeds dit merk te kopen. Het is zeer moeilijk voor u om van merk te veranderen.). Deze operationalisatie is gebaseerd op onze aanvankelijke definitie van ware merktrouw die aansluit bij Model I.

De analyse van de resultaten van het empirisch onderzoek op basis van Model I laat onder andere zien dat tussen de mate van tevredenheid in het algemeen en ware merktrouw geen directe relatie bestaat; dat tussen de mate van tevredenheid en commitment een zwakke positieve relatie bestaat en dat er een zwakke positieve relatie bestaat tussen commitment en ware merktrouw. De mate van tevredenheid op zich blijkt dus nauwelijks van belang te zijn bij de verklaring van ware merktrouw. Tot op zekere hoogte zijn deze uitkomsten niet verrassend omdat al is aangegeven dat het noodzakelijk is een aantal onderscheidingen aan te brengen in de - vanzelfsprekend klinkende - relatie tussen tevredenheid en ware merktrouw. Echter, wanneer een onderscheid wordt gemaakt tussen manifeste en latente tevredenheid blijkt nog niet dat een duidelijke relatie tussen tevredenheid en ware merktrouw kan worden vastgesteld.

Mede omdat deze bevindingen niet in overeenstemming zijn met de verwachtingen en omdat ware merktrouw op verschillende manieren (ook conceptueel) kan worden gedefiniëerd en geoperationaliseerd, wordt Model I aan een kritische evaluatie onderworpen. In Model I wordt commitment opgevat als een noodzakelijke voorwaarde voor ware merktrouw en dus als een onafhankelijke variabele. Commitment kan echter ook worden opgevat als een onlosmakelijk aspect van ware merktrouw. Commitment maakt dan deel uit van de afhankelijke variabele (ware merktrouw). De definitie van ware merktrouw wordt aangepast en luidt vervolgens: "the biased (i.e. nonrandom) behavioral response (i.e purchase, expressed over time, by some decision making unit, with respect to one or more alternative brands out of a set of such brands, and is a function of brand commitment, which, in turn, is a result of psychological (decision making, evaluative) processes".

Deze aanpassing van de definitie betekent dat ware merktrouw nu wordt opgevat als een concept dat zowel uit gedrags- als psychologische aspecten is opgebouwd. Deze herdefiniëring heeft consequenties voor het onderzoeksmodel en de operationalisatie van ware merktrouw. Commitment is niet langer een interveniërende variabele in de relatie tussen tevredenheid en merktrouw. Tevens wordt een alternatieve operationalisatie van ware 
merktrouw geïntroduceerd: loyaliteit. Deze is gebaseerd is op de nieuwe definitie van ware merktrouw. Loyaliteit is de kans op een herhalingsaankoop waarbij rekening wordt gehouden met de mate van commitment bij het merk. Ondanks de aanpassing van de definitie liggen ware merktrouw en herhalingsaankopen ook nu weer op eén continuüm.

Figuur D geeft een overzicht van het geherformuleerde onderzoeksmodel: Model II.

Figuur D: Model II van de relatie tussen herhalingsaankopen en latente tevredenheid en de relatie tussen ware merktrouw en manifeste tevredenheid.

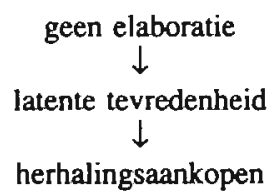

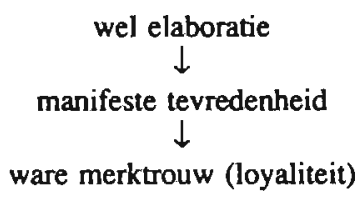

De belangrijkste hypothese van ons onderzoek luidt vervolgens: "De positieve directe relatie tussen manifeste tevredenheid en ware merktrouw is sterker dan de positieve directe relatie tussen latente tevredenheid en ware merktrouw".

Deze hypothese wordt bevestigd met de data verkregen uit het empirisch hoofdonderzoek, waarbij ware merktrouw wordt geoperationaliseerd als loyaliteit (hoofdstuk 8). Er moet echter worden opgemerkt dat de rol die tevredenheid speelt bij de verklaring van ware merktrouw gering is. Opvallend is dat de motivatie om de merkkeuze te evalueren, de belangrijkste verklarende variabele van ware merktrouw blijkt te zijn, gegeven een zekere mate van tevredenheid. Daarnaast is het opmerkelijk dat de capaciteit van de consument om de merkkeuze te evalueren mogelijk in negatieve zin bijdraagt aan de verklaring van ware merktrouw (eveneens gegeven een zekere mate van tevredenheid). Hoewel in het empirisch onderzoek gebruik is gemaakt van twee verschillende produkten (cassettebandjes en haarshampoo) is de gelijkenis, als het gaat om de geconstateerde relatie tussen tevredenheid en ware merktrouw opmerkelijk groot.

De belangrijkste implicaties van onze bevindingen zijn dat het noodzakelijk is een onderscheid te maken tussen ware merktrouw en herhalingsaankopen en dat de manier waarop een merk wordt geëvalueerd, resulterend in manifeste of latente tevredenheid, van groot belang is bij het bestuderen van de relatie tussen tevredenheid en ware merktrouw. Bovendien blijkt het, overeenkomstig de altematieve definitie van ware merktrouw, aan te bevelen ware merktrouw te definiëren als een combinatie van een gedragsen psychologische aspecten (commitment).

Onderstaand wordt kort per hoofdstuk de inhoud ervan aangeven.

In hoofdstuk 1 wordt een literatuuroverzicht over merktrouw gepresenteerd. Het onderscheid tussen ware merktrouw en herhalingsaankopen zal worden uitgewerkt. Er zal aandacht worden besteed aan de verschillende operationalisaties van merktrouw. Daarbij zullen tevens de verschillende benaderingen van merktrouw worden bestudeerd. Tot slot 
wordt een inventarisatie gemaakt van variabelen die bijdragen aan de verklaring van merktrouw.

De economische en de economisch-psychologische benaderingen van tevredenheid komen in hoofdstuk 2 kort aan de orde. $\mathrm{Er}$ wordt een inventarisatie gemaakt van de verschillende variabelen die bijdragen aan de verklaring van tevredenheid en er wordt ingegaan op de operationalisatie van tevredenheid.

In hoofdstuk 1 en 2 zal blijken dat zowel bij merktrouw als bij tevredenheid, tot op zekere hoogte, dezelfde 'verklarende' variabelen genoemd worden in de literatuur. Wij hebben er voor gekozen om deze afzonderlijk (en dus niet simultaan) te bespreken omdat dit volgens ons het meeste inzicht verschaft.

In hoofdstuk 3 worden de bevindingen uit hoofdstuk 1 en hoofdstuk 2 van commentaar voorzien en met elkaar in verband gebracht. Er wordt een alternatieve visie gegeven op de verklaring van ware merktrouw en de rol van tevredenheid hierbij. Een onderzoeksmodel (Model I) met de bijbehorende hypothesen wordt vervolgens besproken.

Commitment en elaboratie, zo is gebleken in hoofdstuk 3, spelen, volgens ons, naast tevredenheid een rol bij de verklaring van ware merktrouw. Daarom wordt in hoofdstuk 4 met name ingegaan op de operationalisatie van commitment en elaboratie. Involvement en deliberatie worden opgevat als indicatoren voor elaboratie en daarom tevens afzonderlijk besproken.

Hoofdstuk 5 is een methodologisch hoofdstuk. Het gaat over het construeren van schalen voor het meten van commitment, involvement en deliberatie. De betrouwbaarheid en de validiteit van de in het hoofdonderzoek te gebruiken schalen, worden besproken op basis van de resultaten van het verrichte vooronderzoek.

In hoofdstuk 6 wordt aandacht besteed aan de opzet van het empirische hoofdonderzoek en het profiel van de bestudeerde steekproef.

De eerste resultaten en de bivariate analyses van het hoofdonderzoek komen in hoofdstuk 7 aan de orde. Hier zal voor het eerst enig zicht worden verkregen in de rol van tevredenheid en de andere factoren die in hoofdstuk 4 besproken zijn, bij de verklaring van ware merktrouw. Ware merktrouw wordt geoperationaliseerd als een extreem op het continuüm, welke kan variëren van een automatische herhalingsaankoop tot een weloverwogen keuze of ware merktrouw.

De resultaten van de multivariate analyses uit het onderzoek staan in hoofdstuk 8. Uit deze analyses worden nieuwe inzichten verkregen voor de verklaring van ware merktrouw en de rol van verschillende soorten tevredenheid. De aanvankelijke definitie van ware merktrouw vertoont enige tekortkomingen. De tijdens het onderzoek verkregen inzichten gebieden deze aan te passen. De nieuwe definitie houdt nadrukkelijk rekening met zowel het gedrags- als het psychologische aspect van ware merktrouw en wordt 
loyaliteit genoemd. Een aangepast onderzoeksmodel (Model II) met bijbehorende hypothesen wordt gepresenteerd.

Hoofdstuk 9 bevat de conclusies, die naar aanleiding van het onderzoek getrokken kunnen worden. Er wordt aandacht besteed aan de theoretische en de marketing management implicaties van de resultaten. Tevens vindt er een terugkoppeling plaats naar de probleemstelling van dit onderzoek. Tot slot zijn de beperkingen van het onderzoek weergegeven en worden tevens enkele suggesties voor nader onderzoek gedaan.

Schematisch kan dit als volgt worden toegelicht: 


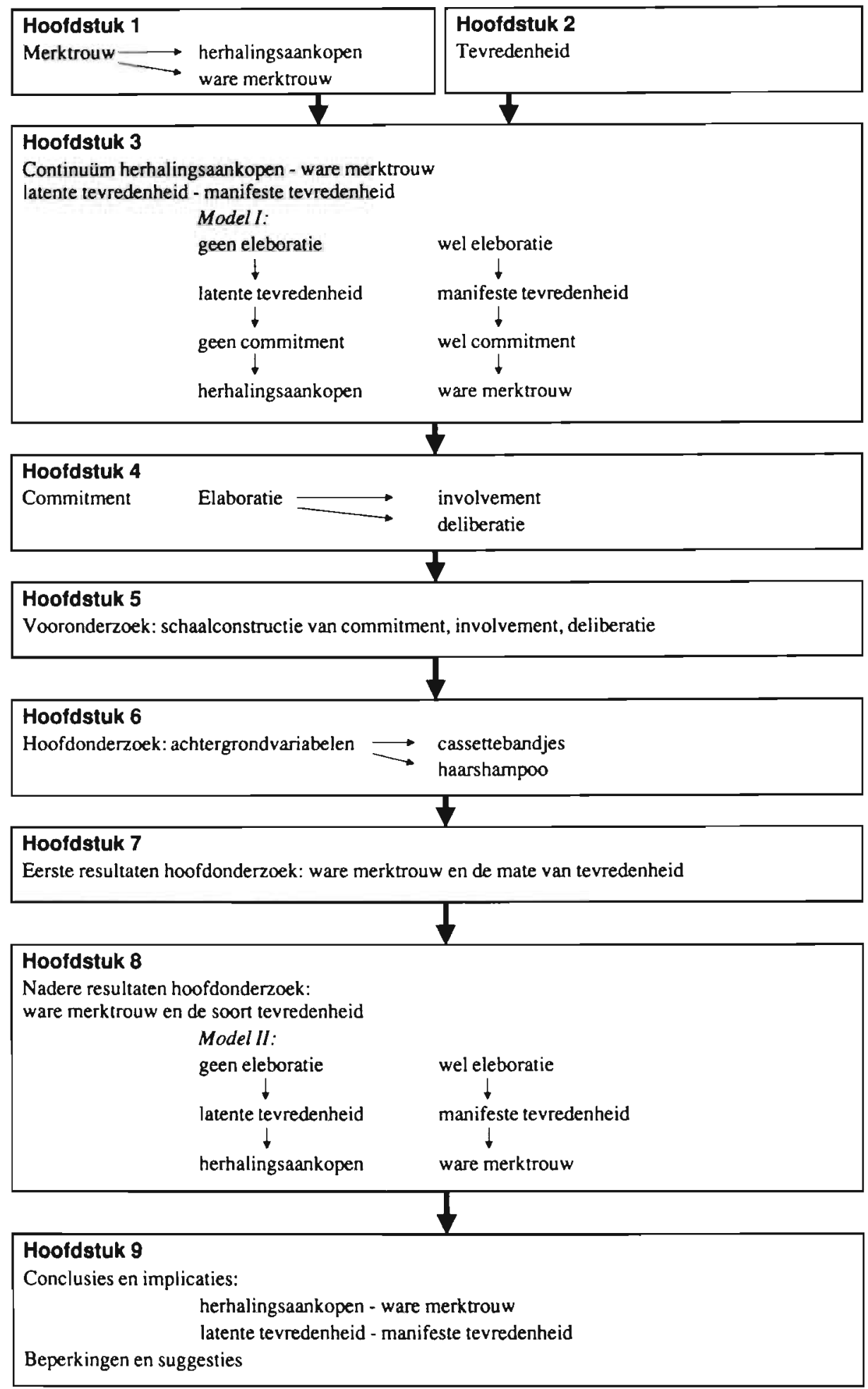




\section{$1.1 \quad$ Inleiding}

In de jaren '20 is voor het eerst in de marketingliteratuur aandacht besteed aan het fenomeen merktrouw (Copeland, 1923). In de eerste jaren daarna is weinig gepubliceerd over dit onderwerp. Pas in het begin van de jaren ' 70 volgen publikaties van onder andere Frank, Massy en Lodahl (1969); Jacoby en Olson (1970) en Ehrenberg (1972). In die tijd is de belangstelling voor merktrouw erg groot. Eind jaren '70, begin jaren ' 80 lijkt er echter weer nauwelijks interesse te bestaan voor dit onderwerp. Dit is onder meer toe te schrijven aan het feit dat merktrouw bij nader inzien een moeilijk te bestuderen fenomeen blijkt te zijn. Eind jaren ' 80 begin jaren ' 90 neemt de belangstelling voor merktrouw weer toe. Deze hernieuwde aandacht voor merktrouw ligt in het verlengde van de grote aandacht die in deze tijd uitgaat naar merken in het algemeen (Franzen en Holzhauer, 1987), 'brand equity' (Aaker, 1991), tevredenheid en kwaliteit (Lemmink, 1991) en het aangaan, behouden en verstevigen van relaties met consumenten (onder andere via direct marketing) en industriële afnemers (onder andere het werk van de IMP-group (Håkansson, 1982 en Ford, 1990)).

Merktrouw wordt voor aanbieders van merkprodukten (goederen en diensten) en voor consumenten van steeds grotere betekenis geacht bij het opbouwen van relaties, met name in verzadigde markten. Aanbieders worden immers geconfronteerd met markten waarop het steeds moeilijker wordt om te groeien. Absoluut gezien neemt het volume van verschillende markten niet langer toe. Het marktaandeel kan vaak alleen ten koste van de concurrent worden vergroot. Niet langer staan de offensieve marketingstrategieën centraal, maar moeten ook defensieve marketingstrategieën worden ontwikkeld. Bij deze defensieve marketingstrategieën komt naast het meer verkopen aan bestaande consumenten (in termen van volume en verschillende produkten), het behouden van consumenten op de eerste plaats. Merktrouw is dan uitermate belangrijk om de doelstellingen van de organisatie op lange termijn te realiseren.

Consumenten worden geconfronteerd met een steeds grotere diversiteit aan produkten en produktvariëteiten. Markten worden hierdoor steeds ondoorzichtiger en het wordt voor de individuele consument steeds moeilijker complexe produkten te beoordelen en een keuze te maken uit het aanbod. Een oplossing voor dit probleem van de consument is merktrouw. Merktrouw vereenvoudigt het keuzeproces van de consument aanzienlijk. Een merktrouwe consument hoeft immers niet steeds opnieuw een beslissing te nemen ten aanzien van de merkkeuze. 
In dit overzicht van de literatuur wordt de conceptuele definitie van merktrouw van Jacoby and Olson als uitgangspunt genomen omdat dit de eerste en de meest algemeen aanvaarde conceptuele definitie is (latere conceptuele definities zijn alle sterk hierdoor beïnvloed). Deze definitie is voor het eerst gepresenteerd en gepubliceerd in 1970 (Jacoby en Olson, 1970), nader toegelicht door Jacoby (1971a) en meer in detail uitgewerkt in Jacoby en Chesnut (1978). Deze definitie van merktrouw luidt:

'Brand loyalty is the biased (i.e. nonrandom), behavioral response (i.e. purchase), expressed over time, by some decision making unit, with respect to one or more alternative brands out of a set of such brands, and is a function of psychological (decisionmaking, evaluative) processes' (Jacoby en Chesnut, 1978, p. 80-81).

De verwarring omtrent de inhoud van het concept merktrouw blijft ondanks deze definitie, groot. Met name omdat vaak geen duidelijk onderscheid wordt aangebracht tussen ware merktrouw en herhalingsaankopen. In het navolgende overzicht wordt de literatuur op een systematische wijze besproken om een zo duidelijk mogelijke structuur en een helder inzicht te verschaffen.

Allereerst zal uitvoerig aandacht worden besteed aan de conceptualisatie van het begrip merktrouw. Merktrouw wordt afgebakend ten opzichte van herhalingsaankopen. Hierdoor zal duidelijk worden dat ware merktrouw en herhalingsaankopen twee verschillende concepten zijn, ook al is het uiteindelijk getoonde gedrag identiek en worden deze concepten vaak als synoniemen gebruikt.

Vervolgens zal ingegaan worden op de operationalisatie van merktrouw; verschillende benaderingen en maten zullen de revue passeren en de voor- en nadelen van deze verschillende benaderingen en maten zullen worden afgewogen. Met name zal aandacht worden besteed aan de deterministische en de stochastische benadering van merktrouw en de binnen deze benaderingen gebruikte maten voor het meten van merktrouw.

Aan het einde van het hoofdstuk wordt aandacht besteed aan de variabelen die een mogelijke bijdrage leveren aan de verklaring van merktrouw. In de loop der jaren zijn veel variabelen onderzocht. De variabelen worden hierbij ingedeeld naar: persoonsgebonden variabelen, aankoopvariabelen, gebruiksvariabelen, marktvariabelen en winkelen dealertrouw. Een aantal van deze variabelen blijkt duidelijk bij te dragen aan de verklaring van merktrouw.

\subsection{Conceptualisatie en afbakening van merktrouw}

Zoals gezegd, de conceptuele definitie van merktrouw van Jacoby en Chesnut (1978, p. 80-81) wordt als uitgangspunt genomen in ons overzicht van de literatuur over merktrouw. Deze definitie bevat zes noodzakelijke en tezamen voldoende voorwaarden om van merktrouw te kunnen spreken:

'Brand loyalty is:

1 the biased (i.e. nonrandom),

2 behavioral response (i.e. purchase), 
3 expressed over time,

4 by some decisionmaking unit,

5 with respect to one or more alternative brands out of a set of such brands, and

6 is a function of psychological (decisionmaking, evaluative) processes.'

Deze zes punten worden door Jacoby en Chesnut (1978) als volgt toegelicht:

\section{Ad. 1}

Wanneer er sprake zou zijn van een random gebeurtenis, zou er geen enkele reden zijn merktrouw nader te bestuderen.

Ad. 2

Alleen een verbale weergave van een uitdrukking van voorkeur of intentie tot aankoop is onvoldoende om van merktrouw te kunnen spreken. Een verbale uiting van merktrouw dient samen te gaan met feitelijk (herhaald)aankoopgedrag.

Ad. 3

Eén enkele aankoop is evenmin voldoende om te kunnen spreken van merktrouw. Merktrouw bevat een tijdselement. Het is daarom noodzakelijk dat tenminste op twee achtereenvolgende momenten hetzelfde produkt wordt aangekocht. Het aankooppatroon door de tijd is van belang.

Ad. 4

De term 'decision making unit' maakt duidelijk dat degene die de aankoop beslissing neemt niet (a) de gebruiker/koper van het produkt behoeft te zijn en niet (b) persé één individu is.

Ad. 5

Deze vijfde conditie betreft twee onderwerpen. Allereerst geldt dat consumenten trouw kunnen zijn aan meerdere merken binnen een produktcategorie (multimerkentrouw). Merktrouw beschrijft dus het voorkeursgedrag ten opzichte van één of meerdere alternatieven gekozen uit een grotere verzameling. (Deze multimerkentrouw laten wij buiten beschouwing omdat, volgens ons, trouw aan meerdere merken tegelijkertijd ook kan worden opgevat als ontrouw ten opzichte van één merk in het bijzonder zelfs indien rekening wordt gehouden met bijvoorbeeld de situatie- of domeinspecificiteit van de merktrouw. Bovendien brengt de bestudering van multimerkentrouw extra complicaties voor het empirisch onderzoek met zich mee mede omdat dan een meer longitudinaal onderzoek gewenst zou zijn. Wij zullen slechts de merktrouw aan één merk in het bijzonder bestuderen in relatie tot tevredenheid.)

Ten tweede geldt dat om te kunnen spreken van merktrouw, er gelegenheid moet zijn om ontrouw te zijn. Er dient dus sprake te zijn van een keuzemogelijkheid; dat wil zeggen, consumenten moeten verschillen tussen merken waarnemen.

Ad. 6

De zesde conditie geeft weer dat merktrouw een functie is van beslissingsgedrag en evaluatieve processen. Merktrouw geeft zo een aankoopbeslissing weer, waarin verschillende merken psychologisch (en wellicht ook fysiek) met elkaar worden vergeleken en geëvalueerd op bepaalde criteria. De uitkomst van deze evaluatie is dat één van de merken wordt geselecteerd.

Als resultaat van het beslissingsgedrag en de evaluatieve processen ontwikkelt de consument 'commitment' met betrekking tot het geselecteerde merk. Het gevolg van deze 
commitment, gedefiniëerd als het nadrukkelijk willen vasthouden aan de merkkeuze in een niet nader omschreven toekomstige koopsituatie, kan zijn merktrouw. (Het begrip commitment wordt in hoofdstuk 4 uitgebreid besproken. Hier wordt er echter nadrukkelijk op gewezen dat de definitie van commitment een 'psychologische' definitie is; zij wijkt daarmee af van gebruikelijke definities binnen andere vakgebieden zoals bijvoorbeeld interne organisatie of industriële economie.)

Jacoby en Chesnut (1978) stellen dat commitment het mogelijk maakt een essentieel onderscheid te maken tussen enerzijds ware merktrouw en anderzijds herhalingsaankopen. Voor ware merktrouw is commitment bij het merk een noodzakelijke voorwaarde; bij herhalingsaankopen is geen commitment bij het merk aanwezig. Commitment als noodzakelijke voorwaarde voor ware merktrouw maakt het tevens mogelijk de relatieve sterkte van de ware merktrouw te bepalen op grond van de mate van commitment.

Andere conceptuele definities van merktrouw zijn sterk beïnvloed door de definitie van Jacoby en Chesnut en sluiten er goed bij aan. Bijvoorbeeld de definitie van Engel et al. (1982, p. 570): "Brand loyalty is the preferential attitudinal and behavioral response toward one or more brands in a product category expressed over a period of time by a consumer (or buyer)"; Assael (1987, p.73): "Brand loyalty represents a favorable attitude toward and consistent purchase of a single brand over time" en Rossiter en Percy (1987, p. 83): "Brand loyalty can be defined as regular (repeat) purchase of the brand based on a favorable price- and promotion-resistant attitude toward it. Brand loyalty is therefore an attitudinal and behavioral concept".

Engel et al. (1982) benadrukken de volgende positieve aspecten van de definitie van Jacoby en Chesnut:

1 Het bestaan van multimerkentrouw wordt expliciet erkend;

2 Merktrouw wordt gezien als een produkt-specifiek fenomeen in plaats van een algemeen attribuut van de consument of de situatie;

$3 \mathrm{Er}$ wordt erkend dat merktrouw een tijdgebonden fenomeen is, dat wil zeggen een tijdsfactor noodzakelijk wordt geacht;

4 De nadruk wordt duidelijk gelegd op degene(n) die de beslissing neemt/nemen;

5 Merktrouw wordt op een continuüm geplaatst. Er is niet langer een zwart/wit tegenstelling tussen merktrouw en merkontrouw. (Zoals gezegd, in ons onderzoek is daarentegen gekozen voor een ander continuüm, namelijk van ware merktrouw tot herhalingsaankopen. Merkontrouw wordt niet op dit continuuim geplaatst omdat in dit geval, in tegenstelling tot ware merktrouw en herhalingsaankopen, een merk niet opnieuw wordt gekocht.)

6 Het opnemen van variabelen die van invloed zijn op zowel het aankoopgedrag als zodanig als op de daarbij behorende psychologische processen.

Bovendien wijzen ook Engel et al. (1982), in aansluiting op Day (1969) en Jacoby en Chesnut (1978), op het belang een duidelijk onderscheid te maken tussen 'intentional loyalty' en 'spurious loyalty'. Day (1969, p. 30) stelt namelijk: "the spuriously loyal buyers lack any attachment to brand attributes, and they can be immediately captured by 
another brand that offers a better deal, a coupon, or enhanced point of purchase visibility through displays or other devices".

'Intentional loyalty' is gebaseerd op zowel een gedragsvariabele (het al dan niet kopen van een merk) als op 'commitment' bij het merk. 'Intentional loyalty' is ware merktrouw in termen van Jacoby en Chesnut. (Het is overigens van belang hierbij te onderkennen dat 'intentional' hier niet gebruikt wordt in de betekenis van mogelijke plannen/intenties, maar van weloverwogen gedrag waarbij de consument nadrukkelijk wenst vast te houden aan de merkkeuze.)

'Spurious loyalty' is gebaseerd op de gedragsvariabele (het al dan niet herhaald kopen van een merk), maar wordt niet veroorzaakt door 'commitment' met betrekking tot een merk. 'Spurious loyalty' is daarom geen ware merktrouw in termen van Jacoby en Chesnut. 'Spurious loyalty' kan worden verklaard door inertia; de consument koopt een merk herhaalde malen vanwege gemak, tijdgebrek, het niet zien van verschillen tussen merken, onverschilligheid of vertrouwdheid met het merk, maar niet omdat de consument nadrukkelijk wil vasthouden aan het merk. (Inertia duidt hier niet op onbewegelijkheid in termen van gedrag; inertia moet worden beschouwd als simpele keuzeheuristieken waar geen duidelijke psychologische (evaluatie- en beslissings) processen aan ten grondslag liggen.)

Wij sluiten ons aan bij dit onderscheid tussen 'intentional loyalty' en 'spurious loyalty'. In het vervolg zal 'intentional loyalty' door ons worden aangeduid als ware merktrouw. 'Spurious loyalty' noemen wij herhalingsaankopen. Bij herhalingsaankopen is het van belang dat een bepaald merk herhaalde malen wordt gekocht. Bij ware merktrouw is daarentegen tevens het psychologische proces dat ten grondslag ligt aan de aankoop, van belang. Om te kunnen spreken van ware merktrouw moet niet alleen een bepaald merk herhaalde malen worden gekocht, maar moet tevens sprake zijn van commitment bij het herhaald aangekochte merk. Ware merktrouw en herhalingsaankopen kunnen alleen op basis van de psychologische processen, die al dan niet uitmonden in een zekere mate van commitment, van elkaar worden onderscheiden omdat het feitelijke gedrag identiek is.

Hoewel wij het belang van het onderscheid tussen ware merktrouw en herhalingsaankopen willen benadrukken, kan in het vervolg van dit hoofdstuk niet steeds een onderscheid tussen beide soorten merktrouw worden gemaakt. Dit heeft alles te maken met het feit dat binnen de bestaande literatuur amper onderscheid wordt gemaakt tussen ware merktrouw en herhalingsaankopen. In het vervolg zal ons literatuuroverzicht daarom betrekking hebben op merktrouw in het algemeen (zowel ware merktrouw als herhalingsaankopen). Het is meestal onduidelijk of hieronder ware merktrouw of herhalingsaankopen moeten worden verstaan omdat bij de operationalisatie van merktrouw geen rekening is gehouden met het wezenlijke verschil tussen de beide concepten. Merktrouw wordt in de bestaande literatuur namelijk vrijwel alleen op gedragsniveau bestudeerd, waardoor het zo noodzakelijke onderscheid tussen ware merktrouw en herhalingsaankopen (wel/geen commitment) verloren gaat. Voor zover mogelijk, zal expliciet worden aangegeven wanneer volgens onze opvatting sprake is van ware merktrouw of herhalingsaankopen. Indien dit niet mogelijk is wordt de algemene term merktrouw gehanteerd. 
Een ander probleem waarmee wij bij de bestudering van de reeds verrichte onderzoeken naar merktrouw te kampen hebben, is het feit dat steeds weer verschillende operationele definities van merktrouw worden gebruikt. Daarbij wordt verzuimd deze operationele definities in een duidelijk conceptueel kader te plaatsen. Merktrouw in conceptuele zin is daardoor precies datgene dat wordt gemeten. In plaats dat de maat voor merktrouw als een indicator voor merktrouw wordt beschouwd, wordt de maat opgevat als zijnde merktrouw. Dit maakt het moeilijk de verschillende operationalisaties met elkaar te vergelijken. Bovendien is bij het ontbreken van een duidelijk conceptueel kader het gevaar groot dat irrelevante aspecten binnen sluipen bij de operationalisatie en dat relevante aspecten buiten beschouwing worden gelaten. Maar door ons onderscheid tussen ware merktrouw en herhalingsaankopen en door het feit dat wij een duidelijke conceptuele definitie als uitgangspunt nemen, proberen wij zo goed mogelijk aan deze problemen tegemoet te komen.

\subsubsection{Verschillende benaderingen bij de operationalisatie van merktrouw}

Sinds het begin van het onderzoek naar merktrouw (Copeland, 1923), is een groot aantal verschillende benaderingen bij het bestuderen van merktrouw toegepast. Er kan een onderscheid worden gemaakt aan de hand van de volgende drie criteria:

1 een micro- versus een macro-benadering;

2 een stochastische- versus een deterministische benadering;

3 een gedragsbenadering versus een psychologische benadering versus een combinatie van beide.

\section{Ad. 1 Micro-versus macro- benadering}

Bij een benadering op micro niveau is het de bedoeling merktrouw te verklaren op het niveau van de individuele consument. Hierbij wordt impliciet de vooronderstelling gemaakt dat merktrouw bestaat, te meten en te verklaren is op individueel niveau.

Bij een benadering op macro niveau is het de bedoeling merktrouw te beschrijven op geaggregeerd niveau, vaak in de vorm van bijvoorbeeld marktaandeelmodellen en veranderingen daarin.

\section{Ad. 2 Stochastische-versus determistische benadering}

Wanneer merktrouw wordt gezien als de uitkomst van een stochastisch proces, is de basis-assumptie dat er een kansfactor aan de tot stand koming van merktrouw ten grondslag ligt. Merktrouw wordt bepaald op basis van gegevens over het aankoopgedrag uit het verleden.

Indien merktrouw wordt gezien als de uitkomst van een deterministisch proces, gaat men ervan uit dat er een aantal duidelijk aanwijsbare factoren (determinanten) zijn, die tezamen merktrouw kunnen verklaren.

\section{Ad. 3 Gedrags-versus psychologisch-benadering en een combinatie}

Bij een gedragsbenadering wordt uitsluitend gebruik gemaakt van feitelijke (observeerbare) gedragingen bij de verklaring van merktrouw. 
De psychologische benadering stelt de psychologische factoren die aan het feitelijke gedrag ten grondslag liggen, centraal.

Wanneer gebruik wordt gemaakt van een combinatie van beide benaderingen, worden zowel het feitelijk, observeerbaar gedrag als de aan het gedrag ten grondslag liggende psychologische factoren gebruikt als verklarende factoren voor merktrouw.

In Schema 1.1 wordt een overzicht gegeven van de verschillende door de tijd gebruikte benaderingen van merktrouw, wanneer we verschillende studies indelen naar de drie genoemde criteria. Doordat iedere studie afzonderlijk op de drie criteria is beoordeeld, kan het voorkomen dat een studie meerdere keren in het schema wordt vermeld.

Bij nadere bestudering van Schema 1.1 kan geconstateerd worden dat éen studie bij verschillende benaderingen kan worden ingedeeld. Een benadering op micro-niveau is meestal een deterministische benadering waarbij gebruik wordt gemaakt van gedragsmaten en/of psychologische maten.

Uit het overzicht is verder af te leiden dat tegenwoordig steeds meer de voorkeur wordt gegeven aan een deterministische benadering boven een stochastische benadering bij de bestudering van merktrouw. De voorkeur van een micro benadering boven een macro benadering hangt hiermee samen. Deze voorkeuren kunnen verklaard worden door het feit dat juist deze benaderingen aanknopingspunten en instrumenten opleveren om merktrouw te kunnen beïnvloeden. Voorts wordt hoofdzakelijk gebruik gemaakt een gedragsbenadering; de psychologische benadering wordt slechts in geringe mate gebruikt om merktrouw te bestuderen. Dit zal veroorzaakt worden door het feit dat feiteliijk gedrag makkelijker kan worden gemeten dan de aan dat gedrag ten grondslag liggende psychologische processen. Nadeel van de gedragsbenadering is, dat geen inzicht wordt verkregen in onderliggende psychologische processen en dat daardoor onduidelijk blijft hoe deze kunnen worden gestuurd.

Zowel de deterministische benadering op micro niveau als de stochastische benadering op macro niveau zullen in het vervolg van dit hoofdstuk nader worden uitgewerkt en geëvalueerd. Bij de deterministische benadering zal hierbij met name aandacht worden besteed aan het onderscheid tussen een gedrags- en een psychologische benadering. Met dit overzicht willen wij meer in detail aangeven welke benaderingen tot nu toe met name zijn gebruikt bij onderzoek naar merktrouw. Het geeft tevens aan van welke resultaten en inzichten wij mede gebruik kunnen maken bij de opzet van ons onderzoek. 
Schema 1.1: Indeling van studies naar merktrouw op basis van verschillende benaderingen.

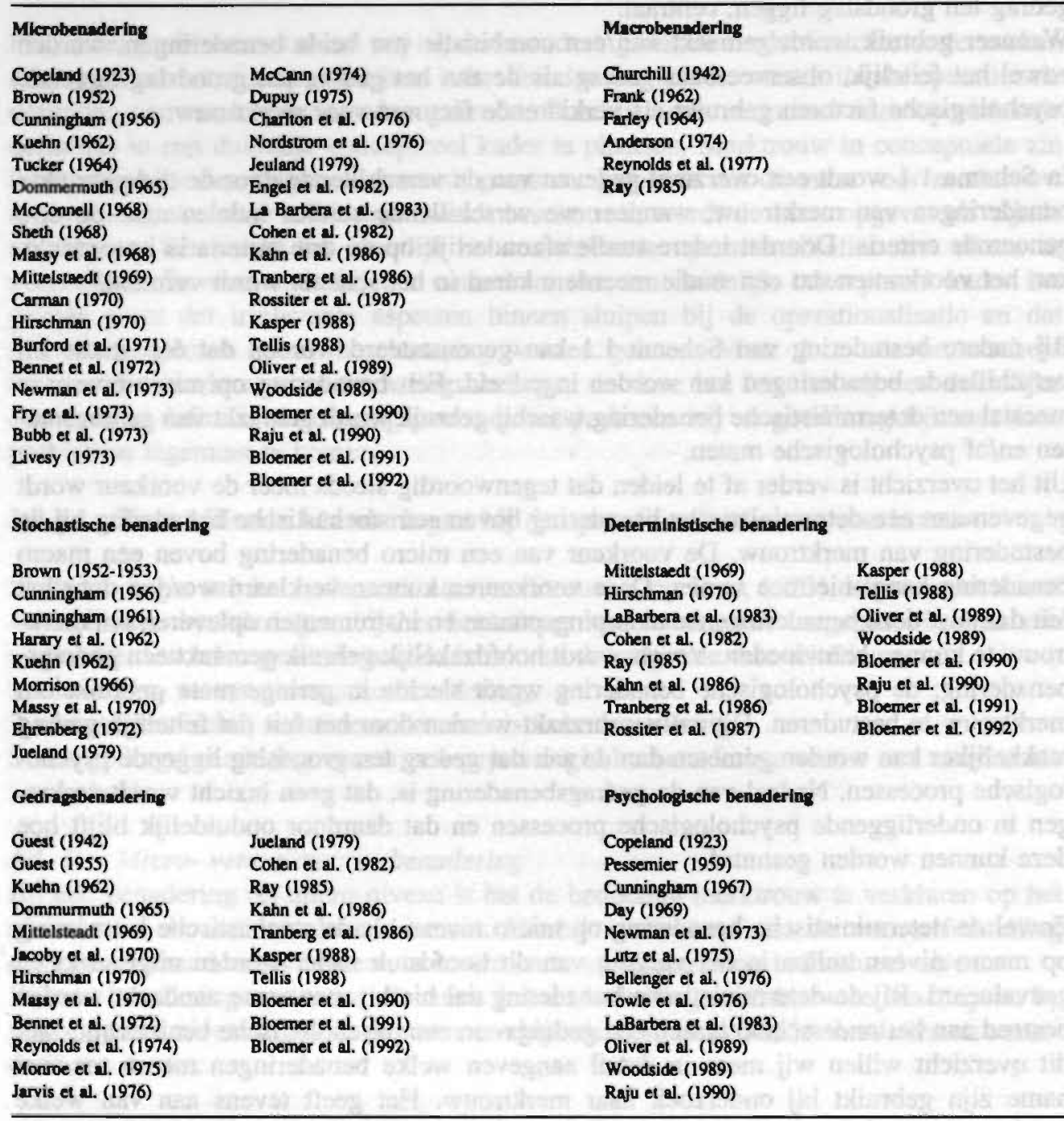

\subsubsection{Uitwerking en evaluatie van de deterministische (micro) benadering van merktrouw}

Uitgaande van de deterministische benadering op micro niveau wordt merktrouw beschouwd als een fenomeen dat op individueel niveau moet worden bestudeerd en verklaard. Om merktrouw te kunnen meten, worden vanuit deze benadering drie verschillende soorten maten onderscheiden: gedragsmaten, psychologische maten en gecombineerde maten (deze maten sluiten aan bij de gedrags- en de psychologische benadering). Voor elk van deze drie soorten maten zal een beschrijving volgen van enkele typerende voorbeelden. $\mathrm{Bij}$ deze voorbeelden wordt aangegeven welke vooronderstellingen daarbij 
gemaakt zijn ten aanzien van de operationalisatie van merktrouw. Vervolgens zal de soort maat worden geëvalueerd. De indeling in soorten maten is gebaseerd op de indeling van Jacoby en Chesnut (1978).

\section{Gedragsmaten}

Proportie van het aantal aankopen, bijvoorbeeld 'market share concept' (Cunningham, 1956).

Merktrouw wordt gedefinieerd in termen van het percentage van de totale aankopen van een produkt dat wordt besteed aan het meest gekochte merk. Een consument wordt merktrouw genoemd wanneer dit percentage hoger dan $50 \%$ is.

Aantal keren dat een merk achter elkaar gekocht wordt, bijvoorbeeld drie in een rij criterium (Tucker, 1964 en McConnell, 1968).

Er is sprake van merktrouw wanneer een bepaald merk drie of meer keren achtereenvolgend wordt gekocht.

Kans op een herhalingsaankoop, bijvoorbeeld 'repeat purchase probability' (Frank, 1962).

Merktrouw wordt uitgedrukt als de proportie van aankopen van een bepaald merk ten opzichte van een totaal aantal aankopen.

Samenstelling van de drie hiervoor genoemde gedragsmaten, bijvoorbeeld 'Sheth factor scores' (Sheth, 1968).

Merktrouw wordt bepaald door de proportie van aankopen van een bepaald merk, gewogen aan de hand van de volgorde waarin verschillende merken zijn gekocht.

Gemengde maten, bijvoorbeeld 'lost-gained ratio' (Cunningham, 1956).

Gelet op de gegevens over aankopen op twee verschillende tijdstippen, bezit het merk met de kleinste ratio van verloren versus gewonnen klanten de grootste merktrouw.

\section{Evaluatie van de gedragsmaten}

Volgens Jacoby en Chesnut (1978) kleven er een aantal nadelen aan de vermelde (en aan nog andere, hier niet specifiek genoemde) gedragsmaten. $\mathrm{Zij}$ stellen onder andere dat:

1 er geen logische, conceptuele basis aanwezig is;

2 de maten te eenvoudig zijn; er wordt slechts naar het gedragsaspect van merktrouw gelet;

3 de gehanteerde criteria veelal arbitrair zijn;

4 de maten niet alles omvattend zijn;

5 er bij de definiëring geen rekening wordt gehouden met multimerkentrouw.

Deze nadelen zijn niet specifiek voor de gedragsmaten. Zij gelden ook voor de psychologische maten (en de gecombineerde maten). Het grote voordeel van de gedragsmaten is volgens ons de eenvoud van de maten en het feit dat zij eenvoudig objectief waar- 
neembaar zijn. Maar het grootste nadeel is uiteraard, dat op basis van de gedragsmaten geen onderscheid kan worden gemaakt tussen ware merktrouw en herhalingsaankopen. Dat de maten arbitrair zijn zou kunnen worden ondervangen door gebruik te maken van een glijdende schaal waarop de mate van merktrouw kan worden uitgedrukt.

\section{Psychologische maten}

Preferentie maten, bijvoorbeeld 'brand preference' (Guest, 1942).

Een consument is trouw aan een bepaald merk als hij dat merk noemt als antwoord op de vraag: Aan welk merk geeft u de voorkeur?

Attitude maten, bijvoorbeeld initiële attitude (Day, 1969).

Merktrouw wordt bepaald op basis van de attitude ten opzichte van het merk. Hoe positiever de attitude des te groter de merktrouw.

Gedragsintenties, bijvoorbeeld 'intent to purchase measure' (Jacoby, Jones en Chesnut, 1979).

Een persoon geeft op een schaal aan hoe groot zijn intentie is om een bepaald merk te kopen; dit weerspiegelt de merktrouw.

Afstand tussen acceptatie- en verwerpingsregio (Jacoby en Olson, 1970).

Hoe groter het verschil tussen een acceptabel merk en de onacceptabele merken, des te groter de merktrouw.

\section{Evaluatie van de psychologische maten}

Specifieke nadelen van de psychologische maten zijn volgens Jacoby en Chesnut (1978) dat:

1 om een onderscheid te maken in de verschillende mate van merktrouw, gebruik wordt gemaakt van intervallen;

2 slechts naar de attitude ten opzichte van één bepaald merk wordt gekeken (volgens ons met uitzondering van de afstand tussen acceptatie- en verwerpingsregio).

Aan deze bezwaren moet volgens ons worden toegevoegd, dat er van de vooronderstelling wordt uitgegaan dat de aan feitelijk gedrag ten grondslag liggende psychologische variabelen, een betrouwbare voorspelling geven van het feitelijke gedrag. (De juistheid van deze vooronderstelling wordt in de literatuur uitgebreid bediscussieerd (bijvoorbeeld Pieters (1989); wij zullen er niet op ingaan gelet op onze probleemstelling). Daarnaast wordt het tijdsaspect van merktrouw buiten beschouwing gelaten; er wordt impliciet vanuit gegaan dat merktrouw op één moment in de tijd kan worden vastgesteld.

Een voordeel van de psychologische maten ten opzichte van de gedragsmaten is dat aandacht wordt besteed aan psychologische constructen die aan het feitelijke gedrag ten grondslag liggen. Hierdoor kan een beter inzicht in de verklaring van merktrouw worden verkregen en kan een vollediger onderscheid worden gemaakt in de relatieve sterkte van merktrouw bij verschillende consumenten in verschillende situaties. 


\section{Gecombineerde maten}

Prijsmaatstaven, bijvoorbeeld 'price until switching' (Pessemier, 1959).

Nagegaan wordt bij welke prijsverandering een consument overstapt van het merk dat zijn voorkeur geniet naar een ander merk. Het gaat hier dus eigenlijk om kruislingse prijselasticiteiten. Consumenten die niet snel overstappen naar een ander merk hebben een grotere merktrouw dan consumenten die wel snel overstappen naar een ander merk.

Merkgehechtheid, bijvoorbeeld 'brand insistence' (Copeland, 1923).

Hierbij wordt nagegaan of (en eventueel in hoeverre) een consument bereid is een ander merk te kopen wanneer het merk dat de consument eigenlijk zou willen kopen, uitverkocht is.

'Stated brand commitment' (Cunningham, 1967).

De consument wordt gevraagd of er een merk is waaraan hij/zij sterk de voorkeur geeft. Wanneer dit merk uitverkocht is, koopt hij/zij dan een ander merk, gaat hij/zij naar een andere winkel, of wacht hij/zij op een andere gelegenheid om het betreffende merk te kopen?

Loyaliteit, bijvoorbeeld 'loyalty index' (Day, 1969).

Loyaliteit $\left(L_{i}\right)$ is de verhouding tussen de proportie aankopen van merk $i\left(P\left(B_{i}\right)\right)$ en de attitude $\left(A_{i}\right)$ met betrekking tot merk i. Dus, $L_{i}=P\left(B_{i}\right) / A_{i}$.

Informatie zoeken, bijvoorbeeld 'brand deliberation/information search' (Newman en Werbel, 1973).

De mate van het zoeken van informatie is naast het feitelijke gedrag van de consument van belang bij de bepaling of een consument al dan niet merktrouw is. Hoe minder er naar informatie wordt gezocht, des te trouwer is de consument.

\section{Evaluatie van gecombineerde maten}

De nadelen van de gecombineerde maten zijn dezelfde als de nadelen van de gedragsmaten en de psychologische maten. Echter de gecombineerde maten hebben volgens Jacoby en Chesnut (1978) drie voordelen boven enkelvoudige gedrags- of psychologische maten omdat:

1 het door gebruik te maken van een gecombineerde maat, het volgens deze auteurs mogelijk is een duidelijk onderscheid te maken tussen ware merktrouw en herhalingsaankopen: zowel het gedrag als het daar aan ten grondslag liggende psychologische construct wordt in de maat betrokken;

2 de gecombineerde maten sensitiever zijn, doordat niet alleen gelet wordt op het feitelijk gedrag maar ook op de aan het gedrag ten grondslag liggende psychologische construct (Aronson en Carlsmith, 1968);

3 de gecombineerde maten over een grotere construct validiteit zullen beschikken (Lutz en Winn, 1975): met de gecombineerde maten beter wordt aangesloten bij de conceptuele definitie van merktrouw. 
De gecombineerde maten sluiten ook volgens ons het beste aan bij de definitie van merktrouw van Jacoby en Chesnut (1978) zoals deze in paragraaf 1.2 is gepresenteerd. Met behulp van deze gecombineerde maten is het beter mogelijk een onderscheid te maken tussen ware merktrouw en herhalingsaankopen.

\subsubsection{Uitwerking en evaluatie van de stochastische (macro) benadering van merktrouw}

Wanneer wordt uitgegaan van een stochastische benadering van merktrouw, zijn er drie basismodellen voor de verklaring van merktrouiw te onderscheiden: het Bernoulli-model, het Markov-model en het lineaire leermodel (deze paragraaf is gebaseerd op Wierenga en Van Raaij, 1987). Bij deze drie modellen wordt uitsluitend uitgegaan van gedragsmaten; de kans op een herhalingsaankoop wordt (op verschillende manieren) voorspeld op basis van één of meerdere voorafgaande aankopen.

\section{Het Bernoulli-model}

Het Bernoulli-model maakt de meest vergaande vooronderstelling over de invloed van voorgaande aankopen op de koopkans; het vooronderstelt namelijk dat deze invloed geheel afwezig is. Daardoor blijft de kans om een merk te kopen constant tijdens het koopproces. Een dergelijk proces, zonder terugkoppeling, met constante kansen wordt een 'proces van de orde nul' genoemd. Het Bernoulli-model beschrijft, ondanks merkwisselingen door individuele consumenten, een statische situatie. Daar de koopkansen constant zijn, is het marktaandeel (de verwachtingswaarde van de koopkansverdeling) dit ook. Voor een korte periode kan dit overigens een zeer goede typering van een markt zijn.

Uiteraard zullen de koopkansen, hoewel voor individuele consumenten wellicht constant in de tijd, in het algemeen niet hetzelfde zijn voor alle consumenten. Doordat preferenties verschillen, zal de ene consument een grotere kans hebben een bepaald merk te kopen dan een andere.

\section{Het Markov model}

In het Markov-model wordt aangenomen dat de koopgeschiedenis van belang is voor de koopkans, maar dat de invloed van eerdere aankopen echter beperkt is tot de invloed van de meest recente aankopen. In het zogenaamde eerste orde Markov-model wordt voorondersteld dat alleen de meest recente aankoop van invloed is op de kans om de volgende keer een bepaald merk te kopen. Bij een Markov-model is het gebruikelijk om te spreken van 'overgangswaarschijnlijkheden'. Een overgangswaarschijnlijkheid van merk $j$ naar merk $k$ is gelijk aan de kans om merk $k$ te kopen, als bij de voorgaande aankoop merk $j$ is gekocht. Een Markov-model kan ook worden gedefinieerd als een hogere-orde-model. Bij voorbeeld in een tweede-orde-Markov-model is niet alleen de laatste, maar ook de voorlaatste aankoop van belang.

Een interessante eigenschap van Markov-model is dat de marktaandelen naar een evenwicht tenderen. 


\section{Het lineaire leermodel}

Terwijl het Bernoulli-model geen enkele invloed van eerdere aankopen op de koopkans kent en bij het Markov-model deze invloed beperkt is tot de meest recente aanko(o)$\mathrm{p}(\mathrm{en})$, geldt voor het lineaire leermodel dat in principe alle voorgaande aankopen van invloed zijn op de kans om bij de eerstvolgende aankoop een bepaald merk te kiezen. In het lineaire leermodel wordt de kans dat op tijdstip $t$ een bepaald merk wordt gekocht, gespecificeerd als een lineaire functie van diezelfde kans én aankooptijdstip eerder en de uitkomst van de toen gemaakte merkkeuze.

Evenals bij het Markov-model, valt bij het lineaire leermodel een zogenaamd evenwichtsmarktaandeel te berekenen. Deze grootheid is te interpreteren als de waarde waarnaar het marktaandeel tendeert als het koopproces in een consumentenpopulatie gedurende lange tijd volgens het betreffende lineaire leermodel verloopt.

Het Bernoulli-model en het Markov-model zijn twee verbijzonderingen van het lineaire leermodel.

\section{Evaluatie van stochastische modellen}

Stochastische modellen zijn geschikt om merktrouw te modelleren en fluctuaties in dit gedrag op macro niveau te voorspellen. $\mathrm{Zij}$ verschaffen echter geen duidelijk inzicht in de oorzaken van het gedrag.

Verder moet erop gewezen worden dat met name bij het gebruik van stochastische modellen het risico bestaat dat:

1 verschillende passende modellen geformuleerd kunnen worden bij een enkele data-set;

2 de heterogeniteit in de data-set (soms) over het hoofd wordt gezien;

3 bij het combineren van verschillende merken of produktklassen problemen ontstaan, wanneer een markt met $\mathrm{N}$-alternatieven wordt 'samengeperst' in een markt met twee alternatieven (dit in verband met de gehanteerde schattingsprocedure).

\subsubsection{Conclusie}

Hoewel de verschillende benaderingen voor het bestuderen van merktrouw op verschillende manieren kunnen worden gecombineerd, zijn alleen de meest voor de hand liggende combinaties en de meest in de literatuur voorkomende benaderingen nader besproken: een deterministische benadering op micro niveau met daarbinnen een onderscheid voor gedrags- en/of psychologische maten; en een stochastische benadering op macro niveau, gebaseerd op gedragsmaten.

Uitgaande van conceptuele definitie van Jacoby en Chesnut (1978) komt, volgens ons, voor het bestuderen van merktrouw met name een deterministische benadering op micro niveau, met behulp van gecombineerde maten in aanmerking. Alleen vanuit deze benadering kan voldoende inzicht worden verkregen in de verklaring van merktrouw op individueel niveau. Juist dat inzicht is van belang, omdat daaruit de mogelijkheden om merktrouw te beïnvloeden en te sturen, kunnen worden afgeleid. Bovendien kan een onderscheid worden gemaakt tussen ware merktrouw en herhalingsaankopen. 
Andere benaderingen bieden, ons inziens, onvoldoende gelegenheid merktrouw te verklaren. De stochastische benadering maakt slechts gebruik van de kansen op herhalingsaankopen en probeert op deze manier merktrouw te voorspellen zonder een duidelijke verklaring te geven. De benadering op macro-niveau schiet te kort omdat daarmee geen inzicht wordt verkregen in de verklaring van merktrouw op individueel niveau. Juist dit inzicht op individueel niveau is van belang omdat dat voor het ontwikkelen en implementeren van het marketingbeleid van belang is.

\section{$1.4 \quad$ Alternatieve benadering van merktrouw}

Hirschman (1970) schetst vanuit een geheel ander perspectief een theoretisch kader waarmee uitingen van tevredenheid en ontevredenheid op de markt geanalyseerd kunnen worden. Daarin is ook plaats voor merktrouw. Deze benadering van merktrouw wordt gezien als een alternatieve benadering omdat zowel aandacht wordt besteed aan marktvariabelen als aan meer psychologische variabelen (in onze opvatting een gecombineerde economische en psychologische benadering). Bovendien wordt merktrouw bestudeerd in relatie tot ontrouw en het uiten van klachten. In de meeste onderzoeken naar merktrouw staan of de marktvariabelen centraal of de psychologische variabelen en wordt trouw los van alternatieve gedragsvarianten bestudeerd.

Hirschman stelt dat consumenten in principe op drie verschillende manieren op het aanbod van producenten kunnen reageren: zij kunnen trouw (loyalty) zijn; het produkt steeds opnieuw kopen, zij kunnen klagen (voice) en zij kunnen het produkt niet langer kopen (exit).

Hirschman hanteert voorts twee uitgangspunten:

1 Consumenten verschillen in de mate waarin zij verschillen percipiëren tussen de prestaties van merken;

2 De reactie van consumenten, wanneer zij ontevreden zijn, is afhankelijk van de perceptie van de oorzaak van die ontevredenheid en het type concurrentie op een bepaalde markt.

Daarom is volgens Hirschman de mate waarin zowel 'exit', 'voice' als 'loyalty' zullen optreden, een functie van verschillende factoren binnen een bepaalde markt, zoals:

1 de gepercipieerde heterogeniteit van de kwaliteit van de aangeboden produkten binnen een produktklasse

Hoe groter de gepercipieerde heterogeniteit in de kwaliteit, des te meer zullen consumenten bij ontevredenheid gebruik maken van 'exit'. Wanneer consumenten zich ervan bewust zijn dat er produkten met een betere prijs/kwaliteitsverhouding op de markt aanwezig zijn, zullen zij sneller voor exit kiezen dan voor 'voice' wanneer zij ontevreden zijn;

2 de ontwikkeling van de consument

Markten waarop zich veel hoog ontwikkelde consumenten bevinden, zullen sneller te maken krijgen met 'exit' bij ontevredenheid dan markten waarop zich minder ontwik- 
kelde consumenten bevinden omdat beter ontwikkelde consumenten naar verwachting meer keuze-alternatieven waarnemen;

3 het gevoel van merktrouw ('feelings of loyalty')

Ondanks het feit dat consumenten zich er van bewust zijn dat er een beter produkt voor handen is, kunnen zij het produkt, voor kortere of langere tijd, blijven kopen. Dit zal zich met name voordoen wanneer een consument zich trouw voelt aan een produkt is. Wanneer deze consument ontevreden is, zal hij/zij gebruik maken van de mogelijkheid tot 'voice' in de hoop dat de fabrikant het produkt waaraan hij/zij trouw is, zal verbeteren;

4 de toe- en uittredingsbarrières voor consumenten

Niet alleen de consument bepaalt de 'loyalty' op een bepaalde markt, ook de producent heeft door het opwerpen van toe- en uittredingsbarrières invloed op de mate van 'loyalty': "High fees for entering an organisation and stiff penalties for exit are among the main devices generating or reinforcing loyalty in such a way as to repress either exit or voice or both...... converting, as it were, conscious into unconscious loyalist behavior" (Hirschman, 1970, p. 93);

5 het verwachte resultaat van 'voice'

Zelfs wanneer consumenten niet zien dat andere produkten van betere kwaliteit op de markt aanwezig zijn, zullen zij kiezen voor 'exit' wanneer zij niet de overtuiging hebben dat 'voice' in enig persoonlijk of collectief gewin zal resulteren;

6 de mate van collectiviteit van 'voice'

Ontevreden consumenten zullen niet kiezen voor 'exit' of 'voice' wanneer zij ervan uit gaan dat andere consumenten klachten voor hen zullen uiten. Tevens zullen zij niet kiezen voor 'exit', maar wel voor 'voice' wanneer zij verwachten dat hun 'voice', opgeteld bij al die anderen tot meer effect zal leiden;

7 de relatieve kosten van 'exit', 'voice' en 'loyalty'

Wanneer ontevreden consumenten weinig opbrengsten verwachten van 'exit' of 'voice' in vergelijking tot de geldelijke en psychologische kosten, zullen zij voor 'loyalty' kiezen.

De verhouding tussen 'exit', 'voice' en 'loyalty' wordt volgens Hirschman op de eerste plaats bepaald door de structuur van de markt waarop een producent zich beweegt (o.a. de concentratiegraad), met inbegrip van het soort produkt of dienst dat wordt aangeboden, de kanalen waarlangs klachten van consumenten kunnen worden geuit en de aanwezigheid van derde partijen zoals consumentenorganisaties. Op individueel niveau veronderstelt Hirschman dat karakteristieken van consumenten van invloed zijn op het soort reactie dat de consument vertoont. Consumenten verschillen in hun mate van 'loyalty', in hun mate van preferentie voor een bepaalde kwaliteit, in de mate waarin zij in staat zijn kwaliteitsverschillen te onderscheiden, in de perceptie van kosten en opbrengsten van 'exit', 'voice' en 'loyalty' en tot slotte in de preferentie voor deze opties.

Het door Hirschman geschetste theoretische kader geeft het belang aan van de bestudering van merktrouw in relatie tot zowel markt- als persoonsgebonden variabelen. Hierbij mag een interactie tussen markt- en persoonsgebondenvariabelen niet over het hoofd worden gezien (zie tevens paragraaf 1.5). Van belang is ook dat in zekere mate een onderscheid tussen bewust en onbewust loyaal gedrag in deze theorie is aangebracht. 
In het vervolg van dit hoofdstuk zal aandacht worden besteed aan de verklaring van merktrouw. Hierbij wordt een onderscheid gemaakt tussen de verschillende soorten variabelen die hierbij genoemd zijn in de vele verrichte empirische studies.

\section{$1.5 \quad$ Verklaring van merktrouw}

Vanuit een deterministische (micro) benadering van merktrouw zijn vele, verschillende variabelen in de loop der jaren aangedragen om een verklaring te bieden voor dit fenomeen. Dit gebeurde over het algemeen met wisselend succes. Dit heeft wellicht te maken met het feit dat merktrouw voomamelijk op gedragsniveau wordt gemeten en er dus geen onderscheid wordt gemaakt tussen ware merktrouw en herhalingsaankopen. Dit zou ook een reden kunnen zijn waarom ten aanzien van sommige verklarende variabelen geen eenduidige resultaten worden gevonden. In feite wordt namelijk geprobeerd twee verschillende soorten gedrag tegelijk te verklaren, namelijk ware merktrouw en herhalingsaankopen. In hun uiteindelijke uiterlijke verschijningsvorm zijn zij wel hetzelfde, maar aan herhalingsaankopen ligt, in tegenstelling tot aan ware merktrouw, geen commitment ten grondslag.

Zolang onduidelijk is om welke soort merktrouw (ware merktrouw of herhalingsaankopen) het precies gaat in een studie wordt door ons de term merktrouw gehanteerd. Wanneer duidelijk is dat het in onze terminologie, om ware merktrouw of herhalingsaankopen gaat, zullen deze termen expliciet in de toelichting worden gebruikt.

Concreet betekent dit dat van de in de rest van dit hoofdstuk vermelde onderzoeken, alleen de onderzoeken van Day (1969) en Newman en Werbel (1973) in onze visie nagenoeg ware merktrouw bestuderen. Dit omdat merktrouw niet alleen in termen van gedrag maar ook in termen van attitude (Day) of 'brand deliberation' (Newman en Werbel) wordt geoperationaliseerd. Attitude en 'brand deliberation' kunnen worden opgevat als aan het gedrag ten grondslag liggende psychologische constructen die, in onze visie echter niet identiek zijn aan commitment. Daarom spreken wij ook van nagenoeg of vrijwel ware merktrouw. (Hierop wordt nader teruggekomen in hoofdstuk 3.)

Ondanks het feit dat het tot op heden moeilijk is een goede verklaring te geven voor merktrouw, worden de belangrijkste 'potentiële' verklarende variabelen besproken. Hierbij moet tevens worden opgemerkt dat veel onderzoek naar de verklaring van merktrouw niet van recente datum is en dat zich de laatste jaren grote veranderingen in het consumentengedrag (bijvoorbeeld als gevolg van de toename van de vergrijzing, de vrije tijd en het vrij besteedbaar inkomen) en op veel markten (bijvoorbeeld als gevolg van het steeds grotere aanbod van verschillende merken en produkten) hebben voorgedaan. Wellicht gelden daarom sommige verklarende factoren nu in een ander mate dan voorheen. Merktrouw kan hierdoor in de loop der jaren in een gewijzigd perspectief zijn komen te staan.

In de literatuur komen veel verschillende variabelen (zie Schema 1.2) naar voren, die mogelijk bijdragen aan de verklaring van merktrouw. Deze hebben wij, in aansluiting op bestaande indelingen in de literatuur, gegroepeerd naar persoonsgebonden variabelen, aankoopvariabelen, gebruiksvariabelen, marktvariabelen en winkel- en dealertrouw. 
Gestart wordt met die variabelen die het meest centraal staan binnen ons onderzoek. Sommige variabelen zijn onderling nauw verwant. In de verschillende studies waarover wij rapporteren worden echter voornamelijk bivariate analyses gemaakt tussen de betreffende variabele en merktrouw. In onze rapportage sluiten wij hierbij aan.

Allereerst zal de invloed (richting en waarom) van elk van de vermelde variabelen op merktrouw worden besproken. Er wordt daarbij nogmaals gewezen op het feit dat merktrouw voornamelijk op gedragsniveau is gemeten en dat dus niet steeds duidelijk is of het - in onze terminologie - om herhalingsaankopen of ware merktrouw gaat.

Wellicht ten overvloede willen wij hier toch vermelden dat de door ons getrokken conclusies ten aanzien van de invloed van de verschillende variabelen uiteraard in het licht staan van de beperkingen van de vermelde studies. 


\section{Persoonsgebonden variabelen}

Psychologische produkt variabelen

- commitment

- inertia

- involvement

- tevredenheid

- attitudes

- brand deliberation

- intenties

- evoked set

- perceptie van verschillen tussen merken

- gepercipiecrde risico

- cognitieve dissonantie (reductie)

Sociaal-economische-, demografische- en persoonlijkheidsvariabelen

- algemeen

- leeftijd

- gezinsgrootte

- prijsbewustzijn

- vertrouwen

- optimisme

- prettig vinden om te winkelen

Sociaal psychologische variabelen

- referentiegroepen

\section{Aankoopvariabelen}

- tijd tussen twee aankopen

- tijd voor het doen van aankopen

- aankoopfrequentie

- budgetaandeel van het merk

\section{Gebruiksvariabelen}

- persoonlijk versus huishoudelijk gebruik

- situatie waarin het merk gebruikt wordt

- conspicuous consumption

- lichte versus zware gebruikers

\section{Marktvariabelen}

- introductie van nieuwe merken

- concentratiegraad

- penetratiegraad

- prijs

- promotie

- distributie

- tijd dat een merk op de markt is

\section{Winkeltrouw/dealertrouw}




\subsubsection{Persoonsgebonden variabelen}

\section{Psychologische produktvariabelen}

\section{- commitment}

Commitment wordt door ons gedefinieerd als het nadrukkelijk willen vasthouden aan de merkkeuze in een niet nader omschreven toekomstige koopsituatie. (In hoofdstuk 3 en hoofdstuk 4 wordt nader aandacht aan deze definitie geschonken.)

De rol van commitment bij de verklaring van merktrouw wordt, zoals blijkt uit de bestaande literatuur, vaak op een indirecte en verschillende wijze bestudeerd. Dit wordt veroorzaakt door het feit dat niet wordt uitgegaan van één conceptuele definitie en door het feit dat verschillende indicatoren voor commitment worden gebruikt.

Pessemier (1959) en Raju et al. (1990) gebruiken 'price until switching' als een indicator van commitment. Newman en Werbel (1973) gebruiken 'brand deliberation' als maat voor commitment. Gepercipieerd risico (Cunningham, 1967 en Sheth en Vankatesan, 1968) en attitudes (Day, 1969) worden tevens als indicator voor commitment gebruikt. Ondanks het gebruik van deze verschillende maten melden alle genoemde onderzoeken een duidelijk positief verband tussen deze maten voor commitment en merktrouw.

Jacoby (1971b, p.28) stelt dat: "the more important the product category is to the individual and/or the more ego-involved, personally committed he is to it, the greater the likelihood that some form of brand loyalty exists".

Commitment speelt een duidelijke rol bij de verklaring van merktrouw omdat commitment met betrekking tot een merk betekent dat een consument weloverwogen wil vasthouden aan zijn/haar merkkeuze. Door in deze situatie feitelijk vast te houden aan de merkkeuze en tot een herhalingsaankoop over te gaan is de consument waarlijk merktrouw.

Commitment blijkt bij te dragen aan de verklaring van merktrouw; bij een toenemende commitment neemt de merktrouw toe. In onze terminologie is er dan dus per definitie sprake van ware merktrouw. (Het begrip commitment komt in hoofdstuk 3 nader aan de orde en wordt uitgebreid besproken in hoofdstuk 4.)

\section{- inertia}

Inertia wordt door ons beschouwd als simpele keuzeheuristieken waaraan geen duidelijke psychologische (evaluatie- en beslissings-) processen ten grondslag liggen.

Jeuland (1979) introduceert een kansfactor waarmee inertia kan worden weergegeven. Deze kansfactor is opgenomen in een eerste-orde multi-merk model, naast de normale merkkeuze kansen. Het eerste-orde multi-merk model heeft betrekking op het keuzegedrag van individuele consumenten voor wat betreft regelmatig aangekochte consumptie goederen. De inertia parameter in dit model geeft aan dat het merk dat het laatst gekocht is, de grootste kans heeft om opnieuw te worden gekocht ('lagged' variabele). Bij opname van de inertia parameter voorspelt het model beter dan wanneer gebruik wordt gemaakt van een model zonder de inertia parameter.

Assael (1987) en Engel et al. (1990) wijzen op de rol van inertia als het gaat om het herhaald aankopen van produkten waarbij geen sprake is van commitment. Inertia vormt een oorzaak van herhalingsaankopen. Een merk wordt opnieuw gekocht zonder dat de 
consument werkelijk belang hecht aan het opnieuw kopen van het merk en persé aan de merkkeuze wil vasthouden.

Inertia veroorzaakt dat de consument hetzelfde merk opnieuw koopt, niet vanwege ware merktrouw, maar omdat het de tijd en de moeite niet waard is om naar een altematief te zoeken. Hier is dus uiteindelijk in sterke mate sprake van gemakzucht en gewoontevorming om routinematig hetzelfde te kopen zonder er over na te denken.

Wij concluderen hieruit dat inertia mogelijk een rol speelt bij de verklaring van herhalingsaankopen en niet bij ware merktrouw.

\section{- involvement}

Involvement definiëren wij als de interesse van een subject in de merkkeuze van een produkt. (In hoofdstuk 4 wordt uitgebreid aandacht besteed aan de definiëring van involvement.)

De rol van involvement als verklarende variabele voor merktrouw is in de literatuur nog niet eenduidig vastgesteld. Herhaaldelijk is voorondersteld dat involvement mogelijk een rol speelt bij de verklaring van merktrouw (Sheth en Vankatesan, 1968) maar middels feitelijk onderzoek, is het belang van involvement nog niet empirisch aangetoond.

Engel et al. (1990, p. 33) stellen dat "Brand loyalty, then, can reflect a motivated and difficult to change habit because it is rooted in high involvement". $\mathrm{Zij}$ vooronderstellen dat hoge involvement een noodzakelijke voorwaarde is voor het ontstaan van commitment en dus voor ware merktrouw. Bij lage involvement is er geen sprake van commitment en dus ook niet van ware merktrouw. Hier stellen zij, is sprake van herhalingsaankopen gebaseerd op inertia.

Meerdere auteurs rapporteren een positief verband tussen involvement en commitment met betrekking tot een merk (Sherif, Sherif en Nebergal, 1965; Howard en Sheth, 1969; Lastovicka en Gardner, 1977; Crosby en Taylor, 1983; Zaltman en Wallendorf, 1983; Laurent en Kapferer, 1985; Zaichowsky, 1985; Selin, 1986; Beatty en Smith, 1987; Beatty et al., 1988; Mittal en Lee, 1989 en Goldsmith et al., 1991). Er moet echter wederom worden opgemerkt dat commitment in deze onderzoeken op zeer verschillende manieren is geoperationaliseerd. Wel kunnen we stellen dat de bevindingen van deze onderzoeken een indicatie kunnen vormen voor de mogelijke rol die involvement, wellicht via commitment, speelt bij de verklaring van (ware) merktrouw.

Involvement speelt dus mogelijk een rol bij de verklaring van merktrouw mede omdat, naarmate de involvement bij de produktkeuze toeneemt, de consument een meer weloverwogen merkkeuze zal maken. Een weloverwogen keuze zal gemakkelijker worden herhaald dan een minder weloverwogen keuze. (Uiteraard indien de consument tevreden is met zijn/haar keuze).

Uit het voorgaande leiden wij af dat er een indicatie is dat involvement positief van invloed is op het ontstaan van (ware) merktrouw. Dit kan ook afgeleid worden uit het feit dat involvement een positieve invloed heeft op commitment. Concrete bevindingen betreffende een directe positieve relatie tussen involvement en merktrouw zijn er tot op heden niet. (In hoofdstuk 4 wordt het involvement-concept, in aansluiting op hoofdstuk 3 , verder uitgediept.) 


\section{- tevredenheid}

Tevredenheid definiëren wij als de uitkomst van een subjectieve evaluatie of het gekozen alternatief (produkt/merk) overeenkomt met de verwachtingen van een subject over dat altematief, of deze overtreft. (In hoofdstuk 2 wordt een uitgebreid literatuuroverzicht over tevredenheid gepresenteerd.)

Katona en Mueller (1954) rapporteren dat tevredenheid met een merk leidt tot merktrouw. Kraft, Granbois en Summers (1973) vergelijken drie verschillende maten om te voorspellen welke merken in de loop van de tijd zullen worden aangekocht. De eerste maat is een gesommeerde merk-evaluatie index; per attribuut van een merk wordt op een 5-punts schaal weergegeven of men hier tevreden dan wel ontevreden mee is. De tweede maat is een 7-punts schaal waarop gescoord wordt of de consument vindt dat het merk erg slecht dan wel goed is (overall-score) en de laatste maat is het laatst aangekochte merk. Alle drie de maten (dus ook de eerste (tevredenheids-) maat) blijken goede voorspellers te zijn van de merken die in de loop van de tijd zullen worden aangekocht. Merktrouw neemt toe wanneer de tevredenheid toeneemt en wanneer het algemene oordeel over het produkt beter wordt. Tevredenheid blijkt, in dit onderzoek, de beste voorspelling te geven van merktrouw.

Newman en Werbel (1973) constateren dat er een relatie bestaat tussen merktrouw en de tevredenheid met een merk. Naarmate de tevredenheid toeneemt, stijgt de merktrouw. (In onze opvatting is in dit onderzoek vrijwel sprake van ware merktrouw.)

LaBarbera en Mazursky (1983) tonen aan dat tevredenheid in positieve zin bijdraagt aan de verklaring van merktrouw. Garfein (1987) toont een positieve relatie tussen de mate van gebruik van een produkt (credit-card) en de mate van tevredenheid aan. Kasper (1988) constateert een positieve relatie tussen merktrouw en tevredenheid met een merk kleurentelevisie. Tot slot tonen Bloemer, Kasper en Lemmink (1990) en Bloemer en Lemmink (1991) evenals Burmann (1991) aan dat tevredenheid met de dealer en de tevredenheid met de auto een positieve invloed hebben op merktrouw.

In de literatuur, waarin tevredenheid centraal staat, worden ook enkele studies aangetroffen die het belang van tevredenheid bij de verklaring van merktrouw weergeven. Andreasen (1977) en Day $(1977 ; 1983)$ geven aan dat, net als in de verschillende bekende consumentengedragsmodellen (onder andere Howard en Sheth, 1969), tevredenheid van invloed zal zijn op het herhalingsaankoopproces. Er wordt vanuit gegaan dat tevredenheid een positieve invloed heeft op de bestaande attitude en intentie ten opzichte van het merk en dat hierdoor de kans op het opnieuw aankopen van het merk toeneemt.

Oliver (1980) constateert dat tevredenheid een positieve invloed heeft op toekomstig gedrag via intenties. Oliver en Linda (1981) tonen aan dat de intentie tot merktrouw bijna geheel verklaard kunnen worden door de mate van tevredenheid. Oliver en Swan (1989a) maken eveneens melding van het feit dat tevredenheid zeer sterk positief gerelateerd is aan de intentie tot merktrouw. Woodside et al. (1989) constateren dat tevredenheid $72 \%$ van de variantie in de intentie tot merktrouw verklaart. Halstead en Page (1992) tonen wederom een positieve relatie aan tussen tevredenheid met een merk en de intentie om een merk opnieuw te kopen. (Allen maken zij echter helaas geen onderscheid tussen het ons inziens zo belangrijke verschil tussen ware merktrouw en herhalingsaankopen.) 
Swan et al. (1982) constateren dat er een verband is tussen tevredenheid en merktrouw maar nader onderzoek is volgens hen gewenst omdat de relatie tussen beiden verre van perfect is. Steams et al. (1982, p. 181) merken in dit verband op dat "although there is the axiomatic direct relationship between satisfaction and intention, the relationship may not be as simple as previous research has described". (Dit onderbouwt onze opvatting dat met nog meer variabelen rekening moet worden gehouden.)

Hirschman (1970) veronderstelt, vanuit een meer economische invalshoek, dat tevredenheid één van de factoren is die bepalend is voor het gedrag van consumenten in termen van 'exit', 'voice' en 'loyalty'. Naarmate consumenten meer tevreden zijn, zullen zij meer merktrouw zijn.

Mede omdat tevredenheid de consument bevestigt in zijn/haar keuze, speelt die tevredenheid een rol bij de verklaring van merktrouw.

Concluderend kan gesteld worden dat tevredenheid waarschijnlijk een zeer belangrijke verklarende variabele voor merktrouw is. Tot op heden is echter weinig bekend over de precieze relatie tussen beide grootheden. De resultaten van de tot nu toe uitgevoerde onderzoeken, wijzen op het bestaan van een positieve relatie. Waarschijnlijk spelen nog meer variabelen een rol. Vermoedelijk is tevredenheid veelal een noodzakelijke, maar niet voldoende voorwaarde om tot merktrouw te komen.

\section{- attitudes}

Day (1969) toont aan dat wanneer niet alleen het gedrag van de consument als maat voor merktrouw wordt genomen (het percentage aankopen van een specifiek merk), maar wanneer ook rekening wordt gehouden met de initiële attitude ten opzichte van het merk, het percentage verklaarde variantie voor de merktrouw van individuele consumenten toeneemt van $16 \%$ tot $27 \%$. Dit betekent dat merktrouw beter verklaard kan worden wanneer zowel gebruik wordt gemaakt van gedrags- als attitude-maten, dan wanneer alleen gebruik wordt gemaakt van gedragsmaten. Daarnaast wordt er een positieve relatie tussen attitude en merktrouw geconstateerd.

Hoe positiever de attitude ten opzichte van het merk, des te groter de kans op merktrouw. Er blijkt immers dat geldt: hoe positiever de attitude, hoe groter de kans op een aankoop van dat merk. Wordt de positieve attitude na de aankoop versterkt, dan neemt de kans, dat hetzelfde merk zal worden gekocht, toe.

Attitudes dragen bij aan de verklaring van merktrouw; des te positiever de attitude ten opzichte van het merk, des te groter de vrijwel ware merktrouw.

\section{- brand deliberation}

Newman en Werbel (1973) vergelijken net als Day (1969) een model dat uitsluitend op een gedragsmaat is gebaseerd, met een model dat zowel op een gedragsmaat als op een psychologische maat, in dit geval 'brand deliberation', is gebaseerd. Brand deliberation moet in dit verband worden opgevat als de mate waarin over de merkkeuze wordt nagedacht. (Dit verschilt enigszins van onze definitie van deliberatie zoals deze in hoofdstuk 4 wordt gepresenteerd.) Newman en Werbel hanteren dit concept om weer te geven dat consumenten nog geen duidelijk beslissing hebben genomen en dus nog ontvankelijk zijn voor informatie over andere merken. Het model waarin zowel een 
gedragsmaat als een psychologische maat zijn opgenomen is duidelijk beter in staat een verklaring te geven voor merktrouw $\left(R^{2}=14.5\right.$ versus $\left.R^{2}=22.9\right)$. Naarmate de brand deliberation afneemt, stijgt de merktrouw. (In onze opvatting is hier vrijwel sprake van ware merktrouw (zie tevens paragraaf 3.6).

Tevens blijkt dat naarmate de consument minder over de merkkeuze nadenkt, hij/zij zijn/haar vorige keuze gemakkelijker zal herhalen bij een volgende aankoop.

Wij stellen vast dat brand deliberation in negatieve zin van invloed blijkt te zijn op vrijwel ware merktrouw.

\section{- intenties}

LaBarbera en Mazursky (1983) tonen aan dat het herhaald aankopen van een merk wordt beïnvloed door de intenties met betrekking tot de aankoop. Hoe sterker de intentie om een merk opnieuw te kopen, des te groter de kans op merktrouw.

De intentie tot merktrouw is een variabele ter verklaring van merktrouw omdat door de intentie uitdrukking gegeven wordt aan het voorgenomen gedrag.

Merktrouw wordt dus in positieve zin beïnvloed door de intenties met betrekking tot het herhaald aankopen van een merk.

\section{- evoked set}

Jacoby (1971b) toont aan dat naarmate de omvang van de evoked set (de merken die een consument in overweging neemt bij de merkkeuze) toeneemt, merktrouw afneemt. Wanneer minder merken in de evoked set zijn opgenomen, betekent dit dat minder merken acceptabel worden geacht. Hierdoor neemt de kans toe dat opnieuw hetzelfde merk wordt gekocht.

Geconcludeerd wordt dat het aantal merken dat voor een consument acceptabel is, een negatief verband met merktrouw vertoont.

\section{- perceptie van verschillen tussen merken}

Consumenten die binnen een produktklasse grote kwaliteitsverschillen zien tussen verschillende merken, zijn vaker merktrouw dan consumenten die minder verschillen zien tussen verschillende merken (McConnel, 1968; Jacoby, 1971b; Lamont en Rothe, 1971; Olson en Jacoby, 1971 en Anderson, 1974).

Wanneer grote verschillen tussen merken worden gepercipieerd, zal een duidelijker keuze voor een bepaald merk moeten worden gemaakt door de consument, dan wanneer geen grote verschillen tussen merken worden gepercipieerd. Een duidelijke of weloverwogen keuze zal in dit geval gemakkelijker worden herhaald dan een niet zo wel overwogen keuze. Bovendien zijn er minder acceptabele alternatieven wanneer consumenten grote verschillen tussen merken zien.

Merktrouw is dus in positieve zin afhankelijk van de mate waarin consumenten verschillen tussen merken percipiëren. 
- gepercipieerd risico

Sheth en Venkatesan (1968) stellen, op basis van een laboratoriumstudie, dat een zeker gepercipieerd risico met betrekking tot de merkkeuze een noodzakelijke voorwaarde is voor de ontwikkeling van merktrouw. Het bestaan van andere merken moet dan wel bij de consument bekend zijn en de consument moet op die andere merken kunnen terugvallen. De auteurs vinden een duidelijk positief verband tussen de mate van gepercipieerd risico die een consument voor een bepaald produkt ervaart en de mate van commitment. Thompson (1980) constateert eveneens een positieve relatie tussen het gepercipieerde risico en merktrouw.

Een reden waarom gepercipieerd risico zou bijdragen aan de verklaring van merktrouw is het feit dat wanneer het gepercipieerd risico van het maken van een verkeerde keuze groot is, het meestal veiliger is om bij een eerder gemaakte keuze te blijven.

Vastgesteld wordt dat gepercipieerd risico in positieve zin van invloed is op merktrouw.

- cognitieve dissonantie (reductie)

Mittelstaedt (1969) toont met een laboratoriumstudie aan dat merktrouw een functie is van tevredenheid en cognitieve dissonantie. De reductie van de cognitieve dissonantie leidt tot het verhogen van de preferentie voor het merk en doet volgens Mittelstaedt de kans op een herhalingsaankoop toenemen. Een aantal andere auteurs stellen dat dissonantie reductie met betrekking tot de merkkeuze zal leiden tot merktrouw (Anderson, Taylor en Holloway, 1966; Oshikawa, 1968; Olshavsky en Miller, 1972 en Jacoby en Kyner, 1973).

Reductie van cognitieve dissonantie zou kunnen bijdragen aan de verklaring van merktrouw omdat door deze reductie de consument bevestigd wordt in zijn/haar keuze en dus zal de consument sneller geneigd zijn deze keuze te herhalen.

Concluderend kan vastgesteld worden dat reductie van cognitieve dissonantie positief van invloed is op merktrouw.

Afsluitend kan worden vastgesteld dat de verschillende besproken psychologische variabelen een positieve invloed hebben op merktrouw, behalve 'brand deliberation' en het aantal merken in de evoked set.

Ware merktrouw ontstaat na het doorlopen van evaluatieve- en beslissingsprocessen. Alle genoemde psychologische variabelen zijn van invloed op deze processen en daardoor van invloed op ware merktrouw, behalve - per definitie - inertia.

De genoemde psychologische variabelen zijn in de weergegeven studies door de verschillende auteurs echter veelal gehanteerd als afzonderlijke variabelen om merktrouw of herhalingsaankopen te verklaren. Nu wij dit overzicht gepresenteerd hebben wordt eens te meer duidelijk dat er een onderlinge samenhang is tussen deze variabelen. Hierop zal in hoofdstuk 3 worden teruggekomen. 


\section{- algemeen}

Cunningham (1956), Guest (1964), Frank en Boyd (1965) en Coulson (1966) constateren geen verband tussen socio-economische en demografische factoren en merktrouw. De Advertising Research Foundation (1964) constateert eveneens geen duidelijke relaties tussen socio-economische-, demografische- en persoonlijkheidsvariabelen en merktrouw op huishoudelijk niveau voor verschillende dagelijkse consumptiegoederen. Daamaast constateren Frank, Massy en Lodahl (1969), gebruik makend van de data uit het onderzoek van de Advertising Research Foundation, bij de analyse van andere dagelijkse consumptie goederen, evenmin duidelijke relaties tussen socio-economische, demografische en persoonlijkheidsvariabelen en merktrouw. De algemene conclusie van dit onderzoek is dan ook dat het persoonlijkheidsprofiel en de socio-economische- en demografische karakteristieken niet werkelijk verschillen tussen huishoudens die merktrouw zijn en huishoudens die niet merktrouw zijn. Voor de volledigheid besteden wij echter toch nadere aandacht aan deze karakteristieken.

\section{- leeftijd}

Tranberg en Hansen (1986) concluderen dat verschillen in merktrouw niet verklaard kunnen worden door demografische verschillen tussen consumenten, zoals sexe, inkomen etc.. Wel vinden zij een zwak positief verband tussen de leeftijd van een consument en de mate van merktrouw. De volgende auteurs waren eveneens al tot de conclusie gekomen dat naarmate de leeftijd van de consument toeneemt, er vaker sprake is van merktrouw: Day (1969), McHale (1971), Lamont en Rothe (1971) en Newman en Werbel (1973). Dat leeftijd van invloed is op merktrouw kan verklaard worden aan de hand van het feit dat oudere consumenten, meer dan jongere consumenten, risico's willen vermijden die gepaard gaan met het wisselen van merk en dus vasthouden aan het bestaande, vertrouwde produkt. (In onze opvatting wordt in de onderzoeken van Day (1969) en Newman en Werbel (1973) vrijwel ware merktrouw bestudeerd (zie tevens paragraaf 3.6).)

\section{- gezinsgrootte}

$\mathrm{Er}$ is ons één studie bekend waarin het verband tussen merktrouw en gezinsgrootte is aangetoond. In andere studies kan dit verband niet worden aangetoond; alleen Day (1969) concludeert dat kleine gezinnen vaker merktrouw zijn dan grote gezinnen omdat in kleine gezinnen minder individuen invloed uitoefenen op de merkkeuze.

\section{- prijsbewustzijn}

Day (1969) toont aan dat consumenten die merktrouw zijn, prijsbewuster inkopen dan consumenten die niet merktrouw zijn. Prijsbewuste consumenten willen blijkbaar vasthouden aan een merk met een constante (lage) prijs.

\section{- vertrouwen}

Vertrouwen in het eigen oordeel over een merk blijkt positief samen te hangen met merktrouw (Day, 1969). Door voortdurende omgang met een merk, zal de kennis met 
betrekking tot het merk toenemen en zal de consument meer vertrouwen krijgen in zijn/haar oordeel over een merk en vaker merktrouw zijn.

\section{- optimisme}

Newman en Werbel (1973) komen in hun onderzoek tot de conclusie dat consumenten die optimistisch zijn met betrekking tot de toekomst, minder merktrouw laten zien dan consumenten die minder optimistisch zijn. Wellicht leidt het optimisme met betrekking tot de toekomst ertoe dat de consument sneller geneigd is risico's te lopen door het kiezen van andere merken dan het vertrouwde merk.

\section{- prettig vinden om te winkelen}

Merktrouw blijkt in negatieve zin gerelateerd te zijn aan de mate waarin men het prettig vindt om te winkelen. Consumenten die het niet prettig vinden om te winkelen komen slechts in enkele winkels. In deze winkels zijn zij veelal trouw aan een zeer beperkt aantal merken (Tranberg en Hansen, 1986).

Er kan gesteld worden dat de gebruikelijke socio-economische-, demografische en persoonlijkheidsvariabelen, met uitzondering van leeftijd, geen goede basis vormen voor de verklaring van merktrouw, zeker wanneer geen onderscheid wordt gemaakt tussen de verschillende soorten merktrouw. Prijsbewustzijn en het vertrouwen in het eigen oordeel dragen in positieve zin en optimisme en het prettig vinden om te winkelen en de gezinsgrootte dragen in negatieve zin bij aan de verklaring van merktrouw.

\section{Sociaal-psychologische variabelen}

\section{- referentiegroepen}

Wanneer gekeken wordt naar de rol van referentiegroepen bij de verklaring van merktrouw, constateert Stafford (1966) dat er geen relatie bestaat tussen de mate van samenhang binnen deze groepen en merktrouw. Wel constateert hij dat in sterk samenhangende groepen, de mate van merktrouw van de leden sterk gerelateerd is aan het merkkeuzegedrag van de informele leider.

Carman (1970) komt tot de conclusie dat merktrouw positief is gecorreleerd aan de mate waarin de huisvrouw interacteert met de buurt waarin zij woont.

Het gedrag van informele leiders van een referentiegroep blijkt een rol te spelen bij de verklaring van merktrouw. Consumenten zullen zich in het algemeen willen conformeren aan het gedrag van de referentiegroep (of aan het gedrag van de buurt waarin zij wonen). Vanuit deze opvatting is te verwachten dat consumenten zich ook zullen conformeren aan de referentiegroep voor wat betreft gedrag ten aanzien van het opnieuw kopen van eenzelfde merk. 


\subsubsection{Aankoopvariabelen}

- tijd tussen twee op één volgende aankopen van een merk

Verschillende onderzoekers hebben het verband tussen merktrouw en de tijd die verstrijkt tussen twee aankopen van hetzelfde produkt onderzocht. Kuehn (1962) constateert dat de kans dat een consument tweemaal hetzelfde merk koopt bij twee achtereenvolgende aankopen, exponentieel afneemt met de tijd die tussen de beide aankopen ligt. Carman (1966) en Morrison (1966) tonen daarentegen aan dat er geen verband tussen merktrouw en de tijd die tussen twee achtereenvolgende aankopen van hetzelfde produkt bestaat.

Deze verschillen in resultaten zouden te wijten kunnen zijn aan het feit dat verschillende produkten in de verschillende studies zijn bestudeerd. Wanneer een merk recentelijk is aangeschaft, is het aannemelijk dat de uitkomst van het huidige keuzeproces gelijk zal zijn aan die van het vorige keuzeproces. Deze redenatie geldt echter in mindere mate voor een merk dat niet recentelijk is aangeschaft.

\section{- tijd voor het doen van aankopen}

Weinig tijd hebben voor het doen van aankopen, leidt tot merktrouw (Anderson, 1974). Een consument die weinig tijd heeft, zal geen nieuwe merkkeuze maken bij een volgende aankoop, maar terugvallen op de vorige merkkeuze.

\section{- aankoopfrequentie}

Tranberg en Hansen (1986) komen tot de conclusie dat een relatief hoge aankoopfrequentie ten opzichte van andere consumenten positief gerelateerd is aan merktrouw. $\mathrm{Zij}$ verwachten dat dit onder andere te verklaren is uit de reïnforcement die ontstaat uit de herhaalde aankoop.

\section{- budgetaandeel van het merk}

Tranberg en Hansen (1986) constateren tevens een verband tussen het budgetaandeel van een merk en de mate van merktrouw. Merktrouw zal toenemen indien het budgetaandeel van het merk toeneemt. Zij stellen dat dit verschijnsel te verklaren is door het stijgende gepercipieerde risico dat optreedt bij het toenemen van het budgetaandeel van een bepaald merk.

Er kan verondersteld worden dat er een verband bestaat tussen aankoopvariabelen en merktrouw. De tijd tussen twee aankopen, de tijd voor het doen van aankopen, de aankoopfrequentie en het budgetaandeel blijken positief van invloed op merktrouw.

\subsubsection{Gebruiksvariabelen}

\section{- persoonlijk versus huishoudelijk gebruik}

Volgens Tranberg en Hansen (1986) treedt merktrouw vaker op wanneer een merk bestemd is voor huishoudelijk gebruik, dan wanneer het voor individueel gebruik bestemd is. Dit zou te maken kunnen hebben met het feit dat op huishoudelijk niveau een compromis is gesloten tussen individuen. Een keuze die gebaseerd is op een compromis is wellicht minder gemakkelijk te veranderen. 
- situatie waarin het merk gebruikt wordt

Holbrook (1984) wijst op het belang van de gebruikssituatie bij de produktkeuze in het algemeen. Aangenomen wordt dat merktrouw samenhangt met de situatie waarvoor een merk gekocht wordt. Een consument kan trouw zijn aan meerdere merken binnen een bepaalde produktklasse die hij/zij ieder in verschillende gebruikssituaties aanwendt.

\section{- 'conspicuous consumption'}

Tranberg en Hansen (1986) vinden een negatief verband tussen 'conspicuous consumption' (het consumeren van een produkt om daarmee indruk te maken op andere consumenten) en merktrouw. Consumenten zijn.minder merktrouw wanneer het om 'conspicuous consumption' blijkt te gaan. Dit is te verklaren door het feit dat een consument zich, wanneer het om 'conspicuous consumption' gaat, meer door de 'mode' laat beïnvloeden voor wat betreft de merkkeuze.

\section{- lichte versus zware gebruikers}

Kuehn (1962) toont aan, in tegenstelling tot Cunningham (1956; 1967) en Massy, Montgomery en Morrison (1970), dat de merktrouw van zware gebruikers groter is dan van minder zware gebruikers. Day (1969) komt in zijn onderzoek tot de conclusie dat merktrouwe consumenten vaker gebruik maken van een merk. (In deze studie staat in onze opvatting vrijwel ware merktrouw bestudeerd.) Tranberg en Hansen (1986) verwachten dat dit te verklaren is door de reïnforcement die ontstaat uit de herhaalde aankoop. Naar verwachting hangen aankoopfrequentie en de mate van gebruik zeer sterk positief met elkaar samen.

Gebruiksvariabelen blijken van invloed te zijn op merktrouw. Wanneer een produkt bestemd is voor huishoudelijk gebruik, in identieke situaties en er veel wordt geconsumeerd blijkt de merktrouw groter dan wanneer een produkt bestemd is voor individueel gebruik, in verschillende situaties en er weinig wordt geconsumeerd. Is een produkt daarentegen bestemd voor 'conspicuous consumption' dan is de merktrouw kleiner dan wanneer een produkt niet hiervoor bestemd is.

\subsubsection{Marktvariabelen}

- introductie van nieuwe merken binnen een produktklasse

Frank, Massy en Morrison (1964) constateren dat een 'merktrouwhuishouden' een grotere weerstand vertoont bij de acceptatie van nieuwe merken dan een niet 'merktrouwhuishouden'. Frank (1967) constateert bij de introductie van nieuwe merken binnen een produktklasse geen verschil in het gedrag van merktrouwe en niet merktrouwe consumenten. Aaker (1972) toont daarentegen aan dat meer merktrouwe consumenten moeilijker zijn over te halen om een nieuw merk te proberen, dan minder merktrouwe consumenten.

\section{- concentratiegraad}

Een laboratorium studie van Anderson, Taylor en Holloway (1966) toont aan dat hoe groter het aantal op de markt aanwezige merken, des te groter de concentratie van merktrouwe consumenten rond het merk met het grootste marktaandeel. Farley (1964) 
en Weinberg (1973) constateren dat het bestaan van een grote range van elkaar beconcurerende merken aanleiding geeft tot ontrouw. Farley (1964) komt daamaast tot de conclusie dat consumenten vaker merktrouw zijn op markten waar duidelijk éen merk het grootste marktaandeel bezit.

Ray (1985) toont het bestaan van een positieve relatie tussen het aantal merktrouwe consumenten van een merk en het relatieve marktaandeel van dat zelfde merk aan. Merken met een groter marktaandeel hebben een groter aantal merktrouwe consumenten dan merken met een kleiner marktaandeel.

De positieve relatie tussen concentratiegraad en merktrouw is ons inziens op verschillende manieren te verklaren. Enerzijds is het voor de hand liggend dat een merk met een gedurende lange tijd - groot marktaandeel door zeer veel consumenten herhaald gekocht wordt. Anderzijds geldt - op basis van de leertheorie - voor merken met een hoge penetratiegraad dat consumenten meer en/of beter de gelegenheid hebben kennis te maken (te leren) met de verschillende beschikbare merken en zo een standvastiger gedragspatroon ontwikkelen.

\section{- penetratiegraad}

Tranberg en Hansen (1986) merken op dat marktpenetratie in positieve zin is gerelateerd aan merktrouw. Merktrouw komt meer voor bij merken met een hoge penetratiegraad. (Dit verschijnsel zal eveneens te verklaren zijn door de leertheorie en de grootte van het marktaandeel; zie daarom ook onze opmerkingen bij de concentratiegraad.)

- prijs

Cunningham (1956) constateert geen invloed van prijsaanbiedingen op merktrouw. Day (1969) daarentegen constateert dat trouwe consument minder wordt beïnvloed door prijsschommelingen en bepaalde aanbiedingen dan andere consumenten (In deze studie wordt volgens ons vrijwel ware merkentrouw bestudeerd.). Farley (1964) toont echter aan dat prijsfluctuaties leiden tot het afnemen van merktrouw. Ook Tellis (1988) concludeert dat prijsveranderingen kunnen aanzetten tot het veranderen van merk, maar concludeert tevens dat dit effect een functie is van de mate van merktrouw van een consument.

Krishnamurthi en Raj (1991) tonen aan dat merktrouwe consumenten minder prijsgevoelig zijn als het gaat om de keuze van een bepaald merk, maar meer prijsgevoelig zijn als het gaat om de keuze van de hoeveelheid. Wanneer merktrouw zorgt voor terughoudendheid om van merk te veranderen in het licht van veranderende marktcondities, dan is te verwachten dat merktrouwe consumenten worden gekenmerkt door kleinere elasticiteiten dan niet-merktrouwe consumenten. Massy en Frank (1965) constateren echter geen verschil in prijs-, aanbiedings- en reclame-elasticiteiten voor huishoudens die merktrouw zijn en huishoudens die niet-merktrouw zijn. Helsen en Schmittlein (1992) constateren dat consumenten die trouw zijn aan A-merken, minder prijsgevoelig zijn bij produktintrodukties dan consumenten die trouw zijn aan B-, C- of eigen merken.

Tranberg en Hansen (1986) concluderen dat merktrouw toeneemt bij hoger geprijsde artikelen. Dit hangt wellicht samen met het grotere gepercipieerde risico van hoger geprijsde artikelen. Wanneer het risico voor de consument bij de aankoop van een merk stijgt, zal hij/zij dit risico willen reduceren. Dit kan door merktrouw. 
- promotie

Webster (1965) constateert een negatieve correlatie tussen 'dealproneness' en merktrouw. Frank (1967) constateert dat consumenten die merktrouw zijn, niet verschillen in hun gevoeligheid voor promotie in vergelijking met consumenten die niet merktrouw zijn.

Carpenter en Lehman (1985) tonen aan dat met name promotie die informatie omtrent het merk bevat, merktrouw bevordert. Prijspromotie daarentegen kan merktrouw juist in negatieve zin beïnvloeden.

Tellis (1988) concludeert dat reclame voor een merk waaraan de consument niet trouw is, niet snel zal leiden tot het veranderen van merk, maar eerder de voorkeur voor het huidige merk versterkt. Tevens concludeert Tellis dat promotie (features en displays) voor een merk waaraan de consument niet trouw is, wel kan aanzetten tot het veranderen van merk. Dit effect is echter een functie van de mate van merktrouw van een consument.

\section{- distributie}

Farley (1964) komt tot de conclusie dat consumenten vaker trouw zijn aan een merk met een grote distributiespreiding.

(Ons inziens hangt dit ook weer samen met de eerdere opmerkingen over penetratiegraad, concentratiegraad en relatieve marktaandelen.)

- tijd dat een merk op de markt is

Ehrenberg en Charlton (1973) tonen aan dat het veranderen van merk veel vaker voorkomt wanneer een produkt nog maar net op de markt is en dat het evenwicht waarin merktrouw optreedt pas na verloop van tijd in de produkt levenscyclus wordt bereikt.

Marktvariabelen dragen bij aan de verklaring van merktrouw: er is een positieve samenhang tussen merktrouw en concentratiegraad, penetratiegraad, distributiespreiding, lengte van de produkt levenscyclus en de hoogte van de prijs. Introducties van nieuwe produkten zijn minder succesvol wanneer consumenten trouw zijn aan bestaande merken. Dan moet blijkbaar een drempel overwonnen worden om van merk te veranderen; dit proces doet zich ook voor bij prijs- en promotionele acties.

\subsubsection{Winkeltrouw en dealertrouw}

Cunningham (1961) komt tot de conclusie dat er een positieve relatie bestaat tussen merktrouw en winkeltrouw. Massy, Frank en Lodahl (1968) komen tot de conclusie dat de belangrijkste determinant van merktrouw, winkeltrouw is. Carman (1970) en Tranberg en Hansen (1986) tonen eveneens aan dat winkeltrouw één van de belangrijkste determinanten van merktrouw is.

Dit verband zou worden veroorzaakt doordat wanneer consumenten aankopen concentreren in enkele winkels, de kans veel groter is dat zij steeds dezelfde merken aantreffen. De relatie tussen merktrouw en winkeltrouw wordt veroorzaakt door het feit dat winkeltrouw het aantal beschikbare merken voor een consument beperkt. 
Bloemer, Kasper en Lemmink (1990), Bloemer en Lemmink (1991) en Burmann (1991) constateren dat dealertrouw een interveniërende variabele is in de relatie tussen tevredenheid met de service en merktrouw.

Winkeltrouw c.q. dealertrouw is eveneens een variabele die een rol speelt bij de verklaring van merktrouw. Als voornaamste argument kan hierbij genoemd worden dat winkeltrouw het merk-keuze proces vereenvoudigt.

\subsubsection{Conclusie}

Persoonsgebonden variabelen, aankoopvariabelen, gebruiksvariabelen, marktvariabelen en winkel- en dealertrouw blijken een rol te spelen bij de verklaring van merktrouw. Voor de meeste van deze variabelen geldt dat de relatie tussen éen enkele variabele en merktrouw is onderzocht (bivariate studies). In paragraaf 1.6 geven wij systematisch weer welke verbanden gevonden zijn. De verschillende variabelen zullen volgens ons met elkaar interacteren als zij tegelijkertijd in de analyse worden betrokken. Op dit moment zijn ons geen studies bekend waarin de verschillende variabelen simultaan onderzocht zijn.

Gezamenlijk zullen zij een sterkere of minder sterke invloed op merktrouw vertonen dan in afzondering en er zal een onderscheid gemaakt kunnen worden tussen directe en indirecte effecten. Het is daarom volgens ons van belang de onderlinge relaties tussen de verschillende variabelen aan nader onderzoek te onderwerpen. Hierbij moet echter een duidelijk onderscheid worden gemaakt tussen ware merktrouw en herhalingsaankopen. Tot nu toe is dit onderscheid (meestal) niet gemaakt. Het maken van het onderscheid tussen ware merktrouw en herhalingsaankopen zal kunnen leiden tot een beter inzicht in de verklaring van enerzijds ware merktrouw en anderzijds herhalingsaankopen. (Meer hierover in hoofdstuk 3.)

\subsection{Samenvatting}

Merktrouw kan worden gedefinieerd als "the biased, behavioral response, expressed over time, by some decision making unit, with respect to one or more altemative brands out of a set of such brands, and is a function of psychological processes" (Jacoby en Chesnut, 1978).

Commitment, die voortkomt uit het doorlopen van psychologische processen, maakt het mogelijk een essentieel onderscheid te maten tussen twee soorten merktrouw: ware merktrouw en herhalingsaankopen. Voor ware merktrouw is commitment met betrekking tot het merk een noodzakelijke voorwaarde. Bij herhalingsaankopen speelt commitment met betrekking tot het merk geen rol. Het onderscheid tussen ware merktrouw en herhalingsaankopen wordt in de literatuur nauwelijks gemaakt.

Merktrouw (waarbij het onduidelijk is of het ware merktrouw of herhalingsaankopen betreft) wordt op verschillende manieren geoperationaliseerd. Er kan een indeling in operationalisaties worden gemaakt op grond van verschillende benaderingen. De verschillende gehanteerde benaderingen zijn een micro of een macro benadering; een stochastische of een deterministische benadering of een gedrags- versus een psychologische 
benadering versus een combinatie van gedrags- en psychologische benadering. Bij een micro benadering is het de bedoeling merktrouw op individueel niveau te verklaren, bij een macro benadering staat de verklaring van merktrouw op geaggregeerd niveau centraal. Een stochastische benadering heeft als uitgangspunt dat merktrouw kan worden voorspeld met behulp van aankoopkansen en bij een determistische benadering wordt ervan uitgegaan dat verschillende onafhankelijke variabelen kunnen worden geïdentificeerd met behulp waarvan merktrouw kan worden verklaard. De gedragsbenadering stelt het gedrag van de consument centraal terwijl de psychologische benadering de nadruk legt op de verklaring van merktrouw aan de hand van psychologische constructen. De verschillende benaderingen worden op diverse manieren gecombineerd in empirisch onderzoek. Het meest voor de hand liggend is een deterministische benadering op micro-niveau waarbij zogenaamde gecombineerde maatstaven worden gebruikt. Alleen langs deze weg is het mogelijk een goed inzicht te verwerven in het concept van merktrouw. Hierbij kan dan een onderscheid worden gemaakt tussen ware merktrouw en herhalingsaankopen op individueel niveau. In de literatuur wordt deze benadering slechts sporadisch aangetroffen.

Het theoretisch kader van Hirschman, voor de bestudering van merktrouw, maakt duidelijk dat zowel marktvariabelen als persoonsgebondenvariabelen een rol spelen bij de verklaring van merktrouw en dat deze variabelen idealiter in relatie tot elkaar zouden moeten worden bestudeerd. (Gelet op de specifieke aard en doelstelling van ons onderzoek hebben wij voor een andere opzet gekozen.)

Zeer veel verschillende markt- en persoonsgebondenvariabelen zijn in de loop der tijd onderzocht ter verklaring van merktrouw. Er kan een indeling worden gemaakt naar persoonsgebonden variabelen (waaronder worden gerekend psychologische produktvariabelen, sociaal- economische-, demografische- en persoonlijkheidsvariabelen en sociaal psychologische variabelen), aankoopvariabelen, gebruiksvariabelen, marktvariabelen en winkeltrouw. Er moet benadrukt worden, dat in de meerderheid van de onderzoeken waarin de invloed van deze verklarende variabelen is bestudeerd, geen ware merktrouw is onderzocht. Tevens is veelal slechts de invloed van de afzonderlijke variabelen op merktrouw bestudeerd en is weinig aandacht besteed aan de onderlinge samenhang van de verschillende variabelen.

In sommige gevallen zijn de uitkomsten van de verschillende onderzoeken tegenstrijdig. Voor een deel kan dit waarschijnlijk door ontwikkelingen in de tijd verklaard worden. De consument van de jaren ' 80 en '90 gedraagt zich anders dan de consument van de jaren '40 en '50. De keuzemogelijkheden zijn nu veel groter en als gevolg daarvan zal er sprake kunnen zijn van minder merktrouw. Wanneer we de positieve en de negatieve verbanden tussen een variabele en merktrouw samenvatten, dan komt het volgende beeld naar voren (zie Schema 1).

De relatie tussen ware merktrouw en tevredenheid staat centraal in dit onderzoek. Dit hoofdstuk geeft aan dat tevredenheid en noodzakelijke maar geen voldoende voorwaarde is om tot ware merktrouw te komen. Voordat dieper op andere factoren die een rol spelen wordt ingegaan, zal allereerst uitgebreid stil gestaan worden bij het tevredenheids-concept. 
Schema 1.3: Nogmaals verklarende variabelen voor merktrouw

Persoonsgebonden variabelen

Psychologische produkt variabelen

- commitment

- inertia

- involvement

- tevredenheid

- attitudes

- brand deliberation

- intenties

- evoked set

- perceptie van verschillen tussen merken

- gepercipieerd risico

- cognitieve dissonantie (reductie)

Sociaal-economische-, demografische- en persoonlijkheidsvariabelen

- algemeen

- leeftijd

- gezinsgrootte

- prijsbewustzijn

- vertrouwen

- optimisme

- prettig vinden om te winkelen

Sociaal-psychologische variabelen

- referentiegroepen

\section{Aankoopvariabelen}

- tijd tussen twee aankopen

- tijd voor het doen van aankopen

- aankoopfrequentie

- budgetaandeel van het merk

\section{Gebruiksvariabelen}

- persoonlijk versus huishoudelijk gebruik

- situatie waarin het merk gebruikt wordt

- conspicuous consumption

- lichte versus zware gebruikers

Marktvariabelen

- introductie van nieuwe merken

- concentratiegraad

- penetratiegraad

- prijs

- promotie

- distributie

- tijd dat een merk op de markt is

Winkeltrouw/dealertrouw
Relatie met merktrouw

positief ware merktrouw positief herhalingsaankopen

positief

positief

positief

negatief

positief

negatief

positief

positief

positief

?

positief

negatief

positief

positief

negatief

negatief

positief

negatief

negatief

positief

positief

positief huishoudelijk gebruik situatie specifiek

negatief

positief

negatief

positief

positief

?

$?$

positief

positief

positief

*: onduidelijk verband tuśsen variabele en merktrouw 


\section{$2.1 \quad$ Inleiding}

Ongeveer 25 jaar geleden verschijnen de eerste publikaties vanuit marketingperpspectief over consumententevredenheid (Cardozo, 1965). Vervolgens blijft het verscheidene jaren stil rond het onderwerp, tot aan het jaar 1972. In dat jaar worden diverse artikelen gepubliceerd, onder andere door Handy (1972); Lingoes en Pfaff (1972) en Pfaff (1972), die betrekking hebben op onderzoek naar het construeren van een index van consumententevredenheid. Dit onderzoek wordt uitgevoerd in opdracht van het Amerikaanse Ministerie van Landbouw met als doel de tevredenheid van consumenten met voedselprodukten vast te stellen.

De populariteit van het onderwerp is in de V.S. vooral gegroeid in de jaren 1973-1975. De aanzet hiervoor komt van de reeds vermelde studie in opdracht van het Amerikaanse Ministerie van Landbouw, maar meer nog door een opdracht, in 1975, van de Federal Trade Commission tot het houden van een nationaal onderzoek naar consumenten(on)tevredenheid en -klachten. Dit heeft geresulteerd in de TARP-studie $(1979,1986)$. Deze studie geeft een inventarisatie van de in de V.S. meest voorkomende consumentenklachten over goederen en diensten en de al dan niet adequate maatregelen die door bedrijfsleven en overheid naar aanleiding hiervan zijn getroffen.

Ook in Nederland is tevredenheid van consumenten, mede door de rol van consumentenorganisaties, steeds meer in de belangstelling gekomen. Dit moge blijken uit publikaties van onder andere Beukenkamp en Gründemann (1979), Francken (1983), IPM/Interview (1974, 1981), Kasper (1982) en De Vries (1991).

Verschillende factoren spelen in op het succes en dragen verder bij tot de bloei van dit thema van onderzoek. Immers, zowel consumenten als aanbieders van produkten (goederen en diensten) zijn in toenemende mate (mede als gevolg van de ontwikkelingen binnen de marketingfilosofie) van het belang van consumententevredenheid doordrongen: "Satisfaction is important to the individual consumer because it reflects a positive outcome from the outlay of scarce resources and/or the fulfillment of unmet needs", als voor de producent: "Consumer satisfaction is important to the marketeer because it is generally assumed to be a significant determinant of repeat sales, positive worth of mouth, and consumer loyalty" (Bearden en Teel, 1983, p. 21).

Maar wat is tevredenheid? Alvorens een definitie te geven, is het goed een tweetal verschillende benaderingen te schetsen: een economische benadering en een economisch-psychologische benadering. Uiteindelijk zullen wij kiezen voor deze economischpsychologische benadering.

De economische benadering wordt gekenmerkt door het feit dat met name variabelen en theorieën die specifiek aansluiten bij het economisch principe (nutsmaximalisatie onder 
randvoorwaarden) worden gebruikt voor de verklaring van tevredenheid. Wij zullen deze variabelen in het vervolg 'economische' variabelen noemen en de betreffende theorieëen zullen wij 'economisiche' theorieëen noemen.

De economisch-psychologische benadering daarentegen stelt de psychologische factoren en theorieën die bijdragen aan de verklaring van tevredenheid centraal en probeert vanuit het individu een verklaring te geven voor tevredenheid.

Uitgaande van een economische benadering wordt tevredenheid bijvoorbeeld opgevat in termen van het verwachte nut dat een produkt aan de consument verschaft of in termen van de uitkomst van een kosten/baten analyse. De consument is tevreden indien het produkt het hoogst mogelijke nut verschaft of wanneer de baten groter zijn dan de kosten.

Uitgaande van het disconfirmatie-paradigma, binnen de economisch-psychologische benadering, is een consument tevreden met een produkt wanneer bij de evaluatie van het produkt, het produkt aan de verwachtingen voldoet of deze overtreft (confirmatie van verwachtingen of positieve disconfirmatie van verwachtingen). Om te bepalen of een produkt aan de verwachtingen voldoet, wordt ook hier een afweging gemaakt tussen de feitelijke produktprestatie en de verwachtingen over het produkt. Echter de economischpsychologische benadering van tevredenheid geeft een andere, meer psychologische, invulling aan de manier waarop een afweging wordt gemaakt.

Allereerst wordt in dit literatuuroverzicht kort aandacht besteed aan de economische benadering van tevredenheid. Hierbij komen verschillende theorieën en modellen aan de orde. Tevens wordt aandacht besteed aan de economische of marktvariabelen die bijdragen aan de verklaring van tevredenheid.

Vervolgens wordt aandacht besteed aan de economisch-psychologische benadering van tevredenheid. Het disconfirmatie-paradigma zal uitvoerig worden besproken en de verschillende onderdelen van dit paradigma zullen nader worden uitgewerkt. Dit betekent, dat zowel aan het concept van tevredenheid als zodanig, maar ook aan de verschillende determinanten van het concept (de verwachtingen, de feitelijke produktprestatie en de (dis)confirmatie van verwachtingen en prestatie) aandacht wordt geschonken. Hierbij wordt tevens ingegaan op de verschillende manieren waarop consumenten de feitelijke produktprestatie en de verwachtingen met elkaar (kunnen) vergelijken en de rol van de attributie van de oorzaak van het verschil tussen prestatie en verwachtingen.

Daarna wordt ingegaan op de psychologische of persoonsgebonden variabelen die bijdragen aan de verklaring van tevredenheid. Kort wordt ook stil gestaan bij de betekenis van affect voor het ontstaan van tevredenheid. Tot slot wordt aandacht besteed aan de operationalisatie van tevredenheid.

\subsection{Tevredenheid: een economische benadering}

Bij een economische benadering van tevredenheid staat het economisch principe ter verklaring van tevredenheid centraal. Tevredenheid kan vanuit deze benadering worden opgevat als nut. Een consument streeft naar nutsmaximalisatie, gegeven een aantal randvoorwaarden, zoals onzekerheid, onvolledige kennis, 'bounded rationality' etc.. 
Achtereenvolgens zal kort aandacht worden besteed aan de economische benadering van tevredenheid via de karakteristiekentheorie en de hedonistische prijstheorie. Daarna zal aandacht worden besteed aan de verklaring van tevredenheid via het marktniveaumodel van Fornell en Robinson (1983), de transactiekostentheorie en de consumententevredenheidsindex van Fornell (1992).

De karakteristiekentheorie (Lancaster, 1971 en Hauser en Simmie, 1981) is een theorie die gehanteerd kan worden om vanuit een economisch perspectief een verklaring te geven voor het ontstaan van tevredenheid. Uitgangspunt van deze theorie is dat de consument een zo groot mogelijk nut wil realiseren (in onze terminologie stellen wij in dit verband nut, zoals te doen gebruikelijk, gelijk aan tevredenheid) bij de keuze uit verschillende produktvariëteiten. Daarnaast wordt er vanuit gegaan dat elk produkt een combinatie is van attributen, die ieder op zich nut verschaffen.

Wanneer de beschikbare varianten van een produkt worden weergegeven als punten in een multidimensionele ruimte, dan is die combinatie van attributen die de consument het grootste nut oplevert, ook weer te geven als een punt in die multidimensionele ruimte. Dit ideale punt voor de individuele consument, vormt een soort standaard, in het licht waarvan alle verkrijgbare produkten worden beoordeeld. Het produkt dat het dichtst bij het ideale punt ligt (mede gegeven de budgetbeperking), zorgt voor de grootst mogelijke tevredenheid; naarmate het produkt verder van het ideale punt verwijderd is, neemt de tevredenheid af. Produkten met verschillende combinaties van attributen leiden tot een gelijke mate van tevredenheid indien deze produkten zich op een gelijke afstand van het ideale punt bevinden. De verschillende preferenties van individuele consumenten kunnen worden weergegeven als de distributie van de verschillende ideaalpunten in de produktruimte. Zo kan worden verklaard dat een produkt tot een verschillende mate van tevredenheid leidt bij verschillende consumenten. De gebruikelijke assumptie van de karakteristiekentheorie betreffende een stabiel ideaal punt wordt door Holbrook (1984) ongeldig verklaard. Hij stelt dat de ideale punten afhankelijk zijn van de situatie waarin een produkt wordt gebruikt.

Tevredenheid kan vanuit een economisch perspectief ook worden bestudeerd met behulp van de hedonistische prijstheorie (Ratchford, 1975; 1980). Deze theorie kan worden gebruikt om de aantrekkelijkheid (in onze termen te vergelijken met tevredenheid) van een produkt voor een consument te berekenen op basis van de karakteristieken die het produkt bezit (de voorspelde prijs) en die vervolgens te vergelijken met de prijs die in werkelijkheid voor het produkt wordt gevraagd. Wanneer de voorspelde prijs hoger of gelijk is aan de werkelijke prijs, wordt ervan uitgegaan dat de consument tevreden is.

Fornell en Robinson (1983) hebben een 'market-level model' voor de verklaring van consumententevredenheid ontwikkeld (vanuit industrieel- en organisatieperspectief). Dit model bevat drie exogene variabelen: concentratiegraad (als indicatie voor de marktvorm), distributiespreiding en consumentenkosten (prijs). De consumentenkosten worden op geaggregeerd niveau gebruikt als proxy voor gepercipieerde prijs en kwaliteitsproblemen. Hoewel de resultaten van het onderzoek niet eenduidig zijn, blijken consumentenkosten negatief samen te hangen met de tevredenheid over de prijs en de kwaliteit; distributiespreiding blijkt negatief samen te hangen met tevredenheid over de prijs en 
positief samen te hangen met tevredenheid over de kwaliteit. Er wordt geen effect gevonden voor de mate van concentratie binnen een bedrijfstak.

Tevredenheid kan ook worden geanalyseerd vanuit het perspectief van de transactiekostentheorie (Williamson, 1989 en Grönhaug en Gilly, 1991). Bij deze theorie staat centaal dat alle economische transacties zijn gebonden aan contracten. Deze contracten leggen de transactie vast. Maar omdat de contracten vrijwel steeds in meerdere of mindere mate onvolledig zijn, bestaat er onzekerheid over de uitkomst van een transactie. Bovendien wordt voorondersteld dat zowel de aanbieder als de consument (1) slechts beschikken over 'bounded rationality' en (2) opportunistisch zijn.

Tevredenheid wordt vanuit het perspectief van de transactiekostentheorie opgevat in termen van het gerealiseerde transactie risico of de 'spijt' na afloop van de transactie. Grönhaug en Gilly (1991) tonen aan dat consumenten meer tevreden zijn met produkten, waarbij weinig onzekerheid bestaat over het 'contract' tussen aanbieder en consument. Dit zijn met name produkten waarbij geen service hoeft te worden verleend, of produkten die niet behoeven te worden gerepareerd. In het algemeen zijn diensten in dit opzicht, in vergelijking tot goederen, meer aan onzekerheid onderhevig dan goederen. En ons inziens zullen, indien de onzekerheid ten aanzien van de transactie toeneemt, de verwachtingen ten aanzien van de transactie minder gemakkelijk in overeenstemming zijn met (of overtroffen worden door) de feitelijke transactie.

Voorts tonen Grönhaug en Gilly (1991) aan dat op markten waarop de transactie-frequentie groot is, bijvoorbeeld massaprodukten, de tevredenheid groter is dan op markten waarop de transactie-frequentie kleiner is. Op deze laatste markten laten de contracten tussen aanbieder en consument immers meer ruimte voor onzekerheid open. Dit zelfde geldt op het niveau van de individuele consument. De onzekerheid in het contract tussen aanbieder en consument neemt af naarmate aanbieder en consument vaker met elkaar in contact treden. Dus kan de tevredenheid toenemen. Dit kan, ons inziens als volgt verklaard worden: wanneer de transactie-frequentie toeneemt, neemt de onzekerheid ten aanzien van de transactie af. Hierdoor zullen de verwachtingen ten aanzien van de transactie meer in overeenstemming zijn met de feitelijke transactie.

Johnson en Fornell (1991) ontwikkelden een consumenten-index voor het meten van tevredenheid van consumenten met de produkten van verschillende bedrijven in diverse takken van industrie in Zweden. Een economische en een psychologische benadering worden bij het onderzoek met behulp van de index gecombineerd. Tevredenheid wordt namelijk in verband gebracht met zowel economische als psychologische variabelen. Er wordt (Johnson en Fornell, 1991) een zwak positief verband gevonden tussen verwachtingen over de produktprestatie en tevredenheid en tevens wordt er een positief verband gevonden tussen de produktprestatie en tevredenheid. Bovendien blijkt tevredenheid positief samen te hangen met merktrouw.

Fornell (1992) toont in het vervolg van dit onderzoek aan, dat bedrijven die met een heterogeen produkt inspelen op een heterogene markt beter beoordeeld worden in termen van tevredenheid dan bedrijven die met een heterogeen produkt inspelen op een homogene markt of met een homogeen produkt op een heterogene markt. Ook wordt aangetoond, dat bedrijven die afhankelijker zijn van het tevredenheidsoordeel van de consument beter worden beoordeeld in termen van tevredenheid. 
Uitgaande van het economisch principe zijn een aantal theorieën en variabelen besproken die bijdragen aan de verklaring van tevredenheid. Ons inziens moeten deze verklaringen voor tevredenheid worden gecomplementeerd met een meer psychologische invalshoek (zie ook van Veldhoven, 1987; van Witteloostuijn, 1987; 1991 en Earl, 1990) om een nog duidelijker en completer inzicht te verwerven op met name het ontstaan van tevredenheid op individueel niveau. Witteloostuijn (1991, p. 239) stelt in dit verband "flesh and blood is applied to the skeleton by introducing into the economic principle psychological and sociological motives and constraints that complement the traditional economic argument".

Naar onze mening kan tevredenheid het best verklaard worden door gebruik te maken van een gecombineerde benadering, waarbij zowel gebruik wordt gemaakt van kennis uit de economie als van kennis uit de psychologie. Deze combinatie maakt het onderzoek naar tevredenheid weliswaar veelomvattend maar ook gecompliceerd. Daarom ligt bij het meeste onderzoek de nadruk op of een meer economische invalshoek of een meer psychologische invalshoek.

In de literatuur over consumentengedrag en marketing, welke het vertrekpunt van deze studie is, wordt de meeste aandacht besteed aan de economisch-psychologische benadering van tevredenheid. Bij deze benadering staat de verklaring van tevredenheid met behulp van psychologische concepten centraal. Deze benadering komt in de volgende paragraaf aan de orde en zal ook in ons onderzoek centraal staan.

\subsection{Tevredenheid: een economische-psychologische benadering}

In dit literatuuroverzicht staat de economisch-psychologische benadering van tevredenheid centraal. Deze benadering is met name in de consumentengedrags- en marketingliteratuur sterk vertegenwoordigd.

In deze paragraaf zal achtereenvolgens aandacht worden besteed aan de conceptualisatie van tevredenheid, aan een cognitief psychologisch model ter verklaring van tevredenheid gebaseerd op het het disconfirmatie paradigma, aan de afzonderlijke onderdelen van dit model en aan de stand van zaken met betrekking tot de bevindingen met dit model. Vervolgens wordt in deze paragraaf nader ingegaan op de verschillende subjectieve vergelijkings- en attributieprocessen die van invloed zijn op het ontstaan van tevredenheid.

\subsubsection{Tevredenheid: conceptualisatie}

Het concept tevredenheid wordt in de literatuur op verschillende manieren gedefinieerd. Een aantal verschillende conceptuele definities wordt gepresenteerd in Bijlage 1. Deze definities zijn belangrijk omdat er mee wordt aangetoond dat op verschillende manieren tegen het concept tevredenheid wordt aangekeken. Ook is er een ontwikkeling in de tijd zichtbaar.

Over de verschillende definities kan het volgende worden opgemerkt: 
1 Tevredenheid wordt enerzijds gezien als:

- de uitkomst van een evaluatieproces (Howard en Sheth, 1969; LaTour en Peat, 1979; Oliver, 1981; Churchill en Surprenant, 1982 en Westbrook en Reilly, 1983) en anderzijds als:

- een evaluatieproces op zich (Hunt, 1977; Engel en Blackwell, 1982; Bearden en Teel, 1983; Tse en Wilton, 1988; Engel et al. 1990 en Vezina en Nicosia, 1990).

2 De definities van tevredenheid variëren al naar gelang het niveau van specificiteit. De verschillende definities gaan uit van tevredenheid met:

- een produkt (Westbrook en Oliver, 1980; Oliver en Linda, 1981; Swan en Trawick, 1981 en Churchill en Surprenant, 1982);

- een consumptie ervaring (LaTour en Peat, 1979; Oliver, 1980, 1981; Bearden en Teel, 1983; Westbrook en Reilly, 1983; Woodruff, Cadotte en Jenkins, 1983 en Fisk en Young, 1985);

- de verkoper (Swan en Oliver, 1985);

- de winkel (Oliver, 1981);

- een attribuut (Bettman, 1979) en;

- de ervaringen die voorafgaan aan de aankoop (Westbrook, 1977).

3 Over meerdere jaren gezien valt te constateren dat vroeger een meer

- cognitieve benadering van tevredenheid werd gehanteerd (Howard en Sheth, 1969; Day en Landon, 1977 en Hunt, 1977).

Op dit moment zien we dat tevredenheid wordt gezien als een concept dat uit

- cognitieve én affectieve aspecten bestaat (Oliver, 1981; Westbrook, 1987; Oliver, 1989 en Dubé en Schmitt, 1991).

Tevredenheid wordt door ons gedefinieerd als:

De uitkomst van een subjectieve evaluatie of het gekozen alternatief (= produkt/merk) overeenkomt met de verwachtingen van een subject over dat alternatief, of deze overtreft.

De door ons gepresenteerde definitie sluit goed aan bij het door Oliver (1980) geformuleerde disconfirmatie-paradigma (zie paragraaf 2.3.2). Voorts biedt de definitie de ruimte om zowel cognitieve als affectieve aspecten bij de evaluatie te betrekken op specifiek en/of algemeen niveau. Bovendien wordt tevredenheid nadrukkelijk opgevat als de uitkomst van een vergelijkingsproces. Hierdoor past de definitie goed binnen het kader van ons onderzoek.

\subsubsection{Two stage expectancy confirmation model}

In vrijwel alle (economisch-psychologische) definities van tevredenheid, zo ook in onze definitie, staat het hele evaluatieproces centraal (ondanks het feit dat tevredenheid wordt opgevat als de uitkomst van een dergelijk evaluatieproces.) Dit evaluatieproces kan het beste worden toegelicht met behulp van het (dis)confirmatie-paradigma. 
Het 'two stage expectancy confirmation model' van Oliver (1980) geeft in de eerste plaats het (dis)confirmatie-paradigma weer (afweging tussen verwachtingen en feitelijke produktprestatie) en geeft in de tweede plaats inzicht in de antecedenten en consequenties van tevredenheid.

In dit literatuuroverzicht wordt het 'two stage expectancy confirmation model' als uitgangspunt genomen. Dit model wordt weergegeven in Figuur 2.1.

Het 'two stage expectancy confirmation model' (zie Figuur 2.1) kan als volgt worden toegelicht:

1 In het linker deel van Figuur 2.1. wordt aangegeven dat produkt- en merkkeuze functies zijn van intenties, die op hun beurt weer worden beïnvloed door attitudes, overtuigingen, evaluaties en verwachtingen. (Dit is conform het model van Engel, Blackwell en Miniard, 1986);

$2 \mathrm{Na}$ aankoop treedt er disconfirmatie/confirmatie op bij de afweging tussen de verwachtingen over en de feitelijke prestatie van het produkt, dit wordt aangegeven boven in het rechter deel van Figuur 2.1 (disconfirmatie);

3 In het vervolg van het rechter deel van Figuur 2.1. wordt aangegeven dat indien een produkt aan de verwachtingen voldoet (confirmatie) of de verwachtingen overtreft (positieve disconfirmatie), dit resulteert in tevredenheid; deze tevredenheid wordt bovendien beïnvloed door de verwachtingen, overtuigingen en evaluaties uit het verleden (pijl van links).

4 Vervolgens is de attitude ten opzichte van een produkt, na de aankoop, een functie van de mate van tevredenheid. Als de ervaring met een produkt positief is (tevredenheid) dan wordt de attitude in positieve zin versterkt; bovendien wordt de attitude beïnvloed door de attitude in het verleden.

5 Tot slot worden aankoopintenties direct beïnvloed door de attitude die wordt gevormd na de aankoop (en dus indirect door tevredenheid) en door de intentie uit het verleden. Als de ervaringen met een produkt positief zijn geweest dan wordt de kans op merktrouw groter.

De in het 'two stage expectancy confirmation model' weergegeven benadering van tevredenheid is afgeleid van Helson's (1964) adaptatieniveautheorie. Deze theorie gaat ervan uit dat een individu stimuli vergelijkt met een geadapteerde standaard. Verwachtingen over de produktprestatie vervullen de rol van adaptatiestandaard: de produktprestatie wordt vergeleken met de verwachte produktprestatie. Naast het feit dat positieve disconfirmatie van verwachtingen leidt tot tevredenheid kan positieve disconfirmatie van verwachtingen kan er ook voor zorgen dat het adaptatieniveau wordt verhoogd (of verlaagd): dus als gevolg van de ervaringen met de produktprestatie wordt de adaptatiestandaard aangepast. 
Het model van Oliver en de achterliggende theorie hebben aanleiding gegeven tot veel nader onderzoek. Dat het model en de theorie een goede weergave zijn van de antecedenten en consequenties van tevredenheid wordt onder andere aangetoond door Oliver en Linda (1981) en Swan en Trawick (1981; 1982).

Figuur 2.1: Oliver's cognitief model van de antecedenten en consequenties van tevredenheid: 'Two stage expectancy confirmation model'

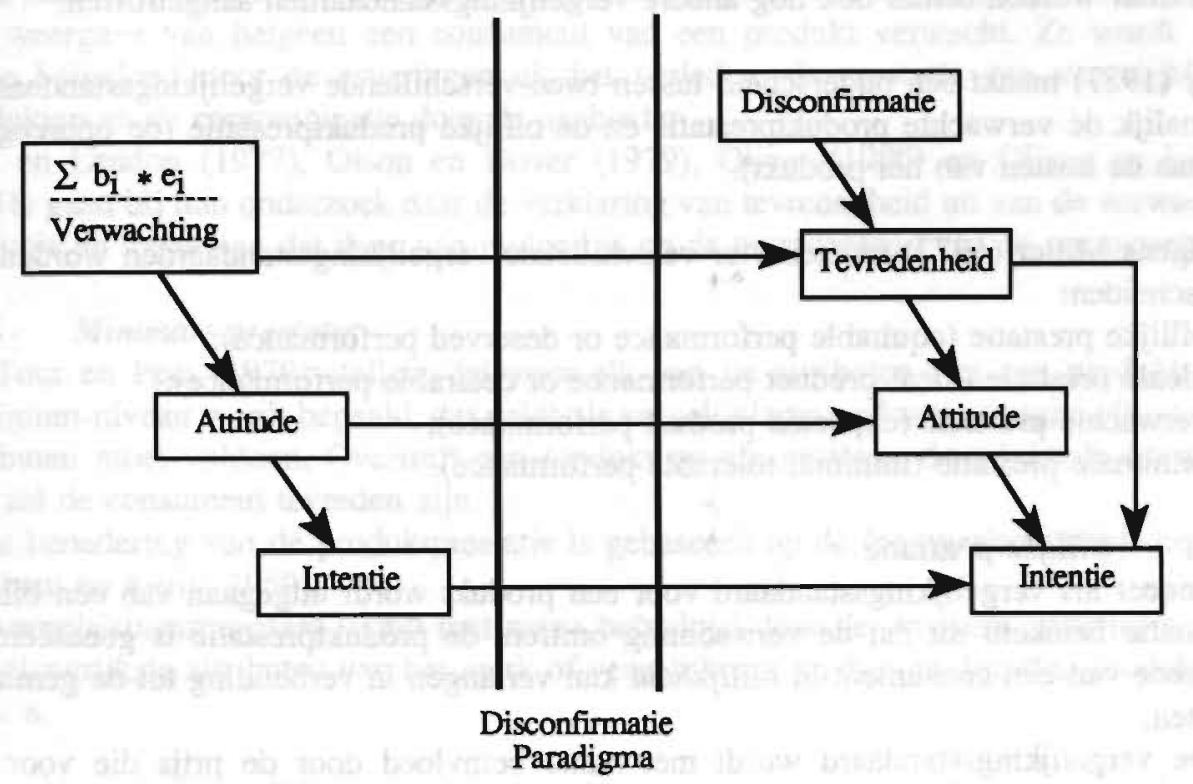

Bron: Oliver (1980, p.462)

In de literatuur over tevredenheid wordt echter met name aandacht besteed aan de antecedenten van tevredenheid. Aan de consequenties van tevredenheid wordt in de literatuur over tevredenheid nauwelijks aandacht besteed. Genoemd worden met name, een positieve attitude verandering, merktrouw en het positief praten over het merk. Merktrouw als consequentie van tevredenheid is in paragraaf 1.5.1 aan de orde geweest. Aan de overige consequenties van tevredenheid wordt in het kader van dit literatuuroverzicht, mede gezien de geringe hoeveelheid empirisch onderzoek, niet expliciet aandacht besteed. Wij zullen ons voorlopig met name concentreren op de antecedenten van tevredenheid.

Bij het ontstaan van tevredenheid spelen dus de verwachtingen over de produktprestatie (paragraaf 2.3.3), de feitelijke produktprestatie (paragraaf 2.3.4) en de uiteindelijk (dis)confirmatie van verwachtingen een rol (paragraaf 2.3.5). Achtereenvolgens zal afzonderlijk op elk van de antecedenten van tevredenheid worden ingegaan. Daarnaast wordt aandacht besteed aan de verschillende subjectieve vergelijkings- en attributieprocessen, die ook een rol spelen bij de verklaring van tevredenheid (paragraaf 2.3.6 en paragraaf 2.3.7). 
De verwachtingen over de produktprestatie zijn een onderdeel van de evaluatie, ten gevolge waarvan tevredenheid ontstaat. Deze verwachtingen met betrekking tot de produktprestatie kunnen op verschillende standaarden worden gebaseerd. Bij het model van Oliver (1980) wordt uitgegaan van de verwachte prestatie van het produkt als standaard waartegen de produktprestatie wordt vergeleken (zie tevens paragraaf 2.3.2.) In de literatuur worden echter ook nog andere vergelijkingsstandaarden aangetroffen.

Day (1977) maakt een onderscheid tussen twee verschillende vergelijkingsstandaarden, namelijk de verwachte produktprestatie en de billijke produktprestatie (de opbrengsten minus de kosten van het produkt).

Volgens Miller (1977) moeten vier verschillende vergelijkingsstandaarden worden onderscheiden:

1 billijke prestatie (equitable performance or deserved performance);

2 ideale prestatie (ideal product performance or desirable performance);

3 verwachte prestatie (expected product performance);

4 minimale prestatie (minimal tolerable performance).

\section{ad 1 Billijke prestatie}

Wanneer als vergelijkingsstandaard voor een produkt wordt uitgegaan van een billijke prestatie betekent dit dat de verwachting omtrent de produktprestatie is gebaseerd op datgene wat een consument in billijkheid kan verlangen in verhouding tot de gemaakte kosten.

Deze vergelijkingsstandaard wordt met name beïnvloed door de prijs die voor een produkt moet worden betaald, de moeite die voor het verkrijgen van het produkt wordt gedaan en de voorafgaande ervaring met het produkt. Het idee van de billijke prestatie als vergelijkingsstandaard voor een produkt is gebaseerd op de billijkheidstheorie (equity theory) van Adams (1963).

Deze vergelijkingsstandaard is terug te vinden in onderzoek over tevredenheid dat gebaseerd is op de aangepaste 'equity theory' van Walster et al. (1973) en Hunt (1980), de 'social equity theory' van Swan en Mercer (1982) en de 'sacrifies theory' van Howard en Sheth (1969).

Ook Swan en Oliver (1985) en Oliver en Swan (1989a, 1989b) maken gebruik van een vergelijkingsstandaard die is gebaseerd op billijkheid. In dit laatste geval echter gaat het om de vergelijking van de input en output van de consument en die van het verkooppersoneel tijdens het koopproces.

\section{ad 2 Ideale prestatie}

De ideale prestatie als vergelijkingsstandaard voor een produkt sluit aan bij de preferentie- en keuzemodellen van Holbrook (1984). Deze standaard geeft weer hoe een produkt idealiter zou kunnen zijn.

Het ideale beeld van een produkt wordt wellicht het meest beïnvloed door de voorafgaande ervaringen met het produkt, de reclame en de mond tot mond communicatie. 
Swan en Trawick (1980a) tonen aan dat de ideale prestatie als vergelijkingsstandaard van invloed is op het tevredenheidsoordeel.

\section{ad 3 Verwachte prestatie}

De verwachte prestatie van een produkt als vergelijkingsstandaard is afgeleid van zowel de verwachtingstheorie (expectancy theory) van Tolman (1932) als van de adaptatietheorie van Helson (1964).

Deze standaard is de meest gehanteerde in onderzoek naar tevredenheid. De standaard is een weergave van hetgeen een consument van een produkt verwacht. Ze wordt met name beïnvloed door de ervaringen uit het verleden, de prestatie van vergelijkbare produkten en de communicatie door de aanbieder.

Day en Landon (1977), Olson en Dover (1979), Oliver (1980) en Oliver en Linda (1981) gaan bij hun onderzoek naar de verklaring van tevredenheid uit van de verwachte prestatie en tonen aan dat deze van invloed is op de tevredenheid van de consument.

\section{ad $4 \quad$ Minimale prestatie}

La Tour en Peat (1979) stellen, dat voor elk van de attributen van een produkt een minimum-niveau wordt bepaald, dat geldt als vergelijkingsstandaard waaraan elk van de attributen moet voldoen. Overtreft een produkt op elk attribuut de minimale prestatie dan zal de consument tevreden zijn.

Deze benadering van de produktprestatie is gebaseerd op de 'comparison level theory' (Thibaut en Kelly, 1959).

De vergelijkingsstandaard wordt met name beïnvloed door de vroegere ervaringen met de belangrijkste attributen van het merk of vergelijkbare merken in dezelfde produktcategorie.

Naast deze vier vergelijkingsstandaarden zijn er nog andere in de literatuur te vinden. Westbrook en Reilly (1983) gaan er in hun 'value-disparity model' vanuit dat de verwachtingen over een produkt gebaseerd worden op de waarden (behoeften, wensen) van de consument. Hoe beter een produkt aansluit bij de waarden van de consument, des te groter zal de tevredenheid zijn.

Hierbij aansluitend kan de benadering van Olshavsky en Spreng (1989) worden vermeld. Deze auteurs gaan ervan uit dat de verwachtingen over een produkt gebaseerd worden op de wensen die de consument heeft ten aanzien van het betreffende produkt.

Morris (1977), evenals Winter en Morris (1979) nemen sociale normen als vergelijkingsstandaard voor de beoordeling van de produktprestatie. Deze normen zijn gebaseerd op wat als algemeen aanvaardbaar geldt.

Volgens Woodruff, Cadotte en Jenkins (1983) worden de verwachtingen over een produkt bepaald door een vooraf gestelde norm ('experienced based norms'). Deze normen hebben twee kenmerken: 1) "they reflect desired performance in meeting needs/wants, 2 ) they are constrained by the performance consumers believe is possible as indicated by the performance of known brands" (p. 306), waarbij er een onderscheid gemaakt kan worden tussen 'best brand norm' en de 'product norm'. De 'best brand norm' is gebaseerd op de ervaring met het beste merk dat de consument kent en de 'product norm' is gebaseerd op de ervaring met andere produkten in dezelfde produktklasse. 
Tse en Wilton (1988) hebben onderzocht welke vergelijkingsstandaard (billijke prestatie, verwachte prestatie en ideale prestatie) het beste bijdraagt aan de verklaring van de mate van tevredenheid. Zij komen tot de conclusie dat billijkheid niet bijdraagt aan de verklaring van tevredenheid. Voor de verwachte prestatie wordt een direct en positief effect op tevredenheid geconstateerd; voor de ideale prestatie wordt een negatief en indirect (via produktprestatie) effect op tevredenheid geconstateerd. (De minimale prestatie is niet opgenomen in dit onderzoek.)

Door Swan en Trawick (1981) wordt eveneens aangetoond dat afzonderlijke standaarden, te weten de verwachte prestatie en de minimale prestatie, bijdragen aan de verklaring van tevredenheid. Swan en Oliver (1985) en Oliver en Swan (1989b) tonen aan dat zowel een billijke prestatie als een verwachte prestatie worden gebruikt als vergelijkingsstandaard (zie tevens Day, 1977).

Deze onderzoeksresultaten duiden er op dat consumenten naar alle waarschijnlijkheid van meer dan én vergelijkingsstandaard tegelijkertijd gebruik maken, wanneer verwachtingen over, en prestaties van een produkt tegen elkaar worden afgewogen. Welke standaard er precies wordt gebruikt en of er gebruik wordt gemaakt van één of meerdere standaarden zal afhankelijk zijn van het produkt, de persoon en de situatie (Churchill en Surprenant, 1982 en Woodruff, Cadotte en Jenkins, 1983).

Samenvattend kunnen wij stellen dat in de literatuur melding wordt gemaakt van verschillende vergelijkingsstandaarden die door consumenten worden gebruikt als basis waartegen de produktprestatie wordt afgezet. Er bestaat geen eenduidigheid over welke standaard het beste kan worden gebruikt bij het onderzoek naar en de verklaring van tevredenheid. Naar verwachting gebruiken consumenten meer dan één standaard tegelijkertijd.

\subsubsection{Feitelijke produktprestatie}

Een ander onderdeel van de evaluatie, ten gevolge waarvan tevredenheid ontstaat, is de feitelijke produktprestatie. Swan en Combs (1976) veronderstellen dat deze feitelijke produktprestatie uit twee verschillende componenten is samengesteld:

1 instrumentele prestatie (fysieke prestatie);

2 expressieve prestatie (psychologische prestatie).

'Instrumental performance refers to the means of a set of ends while expressive performance is performance that the individual considers to be an end in itself' (Swan en Combs, 1976, p. 26). De auteurs komen tot de conclusie (voor wat betreft kleding) dat bevredigende resultaten op de expressieve dimensies van een produkt bijdragen aan de mate van tevredenheid. Bevredigende prestaties op de instrumentele dimensie dragen daarentegen niet bij aan de verklaring van de mate van tevredenheid. Er kan een hiërarchie van effecten worden verondersteld: een acceptabel niveau van instrumentele prestatie is een noodzakelijke, maar niet voldoende, voorwaarde om tevreden te zijn (zie tevens Herzberg et al., 1959). 
Maddox (1981) komt tot de conclusie dat tevredenheid evengoed kan worden verklaard wanneer er geen onderscheid wordt gemaakt tussen een instrumentele en een expressieve dimensie van de produktprestatie als in het geval, dat er wel een onderscheid wordt gemaakt. Het onderzoek naar en het begrijpen van consumententevredenheid wordt door het aanbrengen van dit onderscheid volgens hem alleen maar onnodig gecompliceerd.

In het algemeen wordt in onderzoek naar de verklaring van tevredenheid geen onderscheid gemaakt tussen verschillende dimensies van de produktprestaties. Meestal wordt uitgegaan van de instrumentele prestatie.

\subsubsection{Confirmatie/disconfirmatie}

Op basis van de bestaande literatuur kan een onderscheid gemaakt worden tussen twee verschillende benaderingen van de manier waarop de prestatie van een produkt en de verwachtingen over dat produkt tegen elkaar worden afgewogen.

De eerste is de subtractieve disconfirmatie-benadering. Deze benadering is gebruikt door LaTour en Peat (1979) en Sirgy (1984) en is afgeleid van de 'comparison level theory' van Thibaut en Kelly (1959). Deze benadering gaat ervan uit dat het effect van de vergelijking tussen prestatie ('subjective experienced attribute level') en verwachtingen ('comparison level') kan worden weergegeven als een rekenkundige functie. Voor elk van de belangrijkste attributen van het produkt wordt een vergelijking gemaakt tussen de verwachting en de prestatie. Aan de verschillende attributen kunnen gewichten worden toegekend. De sommatie van alle verschillen tussen verwachting en prestatie van elk van de verschillende attributen geeft de mate van tevredenheid weer. De subtractieve benadering wordt ondersteund door resultaten van onderzoek in de industriële en de cognitieve psychologie (Locke, 1977 en Anderson, 1981).

De tweede en meer algemeen gehanteerde benadering, is de subjectieve disconfirmatiebenadering (Oliver, 1980 en Churchill en Surprenant, 1982). Deze gaat uit van een afzonderlijk psychologisch construct dat een subjectieve evaluatie weergeeft van het verschil tussen produktprestatie en verwachtingen. Dit betekent dat psychologische vergelijkingsprocessen van invloed zijn op de mate van disconfirmatie die wordt ervaren. Deze processen zullen met name dan van belang zijn wanneer het moeilijk is om objectief de verwachtingen en/of de produktprestatie vast te stellen. Bij de subjectieve disconfirmatie benadering is disconfirmatie meer dan de som der delen (dus meer dan het rekenkundige verschil tussen verwachtingen en prestaties gesommeerd voor elk van relevante attributen).

Oliver (1980) formuleert een belangrijk onderscheid tussen beide benaderingen. Hij stelt dat subtractieve disconfirmatie direct zal leiden tot tevredenheid, terwijl subjectieve disconfirmatie een interveniërend "distinct cognitive state resulting from the comparison process and preceding a satisfaction judgement" (p.460) weergeeft. Dit betekent, dat er niet noodzakelijkerwijs een directe associatie bestaat tussen verwachtingen en produktprestatie enerzijds en tevredenheid anderzijds. Door de subjectieve disconfirmatie is ook tevredenheid meer dan de 'som' van de delen. 
Oliver en Bearden (1983) en Tse en Wilton (1988) tonen in hun onderzoek aan dat het gebruik van subtractieve disconfirmatie ter verklaring van tevredenheid tot minder goede resultaten leidt dan het gebruik van subjectieve disconfirmatie. "Further, if CS/D is modelled with direct effects from perceived performance, a comparison standard, and disconfirmation simultaneously, specifying disconfirmation as a subtractive function of the remaining two independent variables will induce overspecification of the CS/D model" (Tse en Wilton, 1988, p. 205).

Yi (1990) brengt in zijn studie van de literatuur een onderscheid tussen objectieve disconfirmatie, afgeleide disconfirmatie en gepercipieerde disconfirmatie.

Objectieve disconfirmatie is het objectieve (rekenkundige) verschil tussen verwachtingen en produktprestatie (bijvoorbeeld Cardozo, 1965; Cohen en Goldberg, 1970; Ilgen, 1971; Olshavsky en Miller, 1972 en Weaver en Brickman, 1974). Hierbij wordt er vanuit gegaan dat de produktprestatie door iedere consument gelijk wordt ervaren.

Afgeleide disconfirmatie is te vergelijken met de eerder genoemde subtractieve disconfirmatie. Voorbeelden van deze benadering zijn te vinden bij LaTour en Peat, 1979; Oliver, 1977, 1979; Swan en Martin, 1981; Swan en Trawick, 1981 en Oliver en Bearden, 1983.

Gepercipieerde disconfirmatie is de subjectieve evaluatie van het verschil tussen produktprestatie en -verwachtingen dat direct wordt waargenomen door de consument. Gepercipieerde disconfirmatie is gelijk aan de eerder genoemde subjectieve disconfirmatie. Voorbeelden zijn te vinden bij Oliver (1977, 1980, 1981); Oliver en Linda (1981); Swan en Trawick (1981); Churchill en Surprenant (1982); Bearden en Teel (1983); Oliver en Bearden (1983); Westbrook en Reilly (1983) en Tse en Wilton (1988).

Gepercipieerde disconfirmatie kan zowel op attribuutniveau als op produktniveau worden gemeten. Een meting op attribuutniveau levert echter geen betere resultaten dan een meting op produktniveau (Yi, 1990).

Kort samengevat blijkt, dat in de literatuur verschillende 'soorten' disconfirmatie onderscheiden worden. De meest gehanteerde benadering is die van de subjectieve disconfirmatie op produktniveau; vandaar dat wij nu nader aandacht zullen besteden aan de specifieke invulling van deze subjectieve vergelijkingsprocessen of evaluatieprocessen.

\subsubsection{Subjectieve vergelijkingsprocessen}

Oliver (1977) stelt, dat wanneer de produktprestatie in overeenstemming is met de verwachtingen of deze overtreft, dit tot tevredenheid leidt.

De theorie van de cognitieve dissonantie, de contrasttheorie, de gegeneraliseerde negativiteit, het geassimileerd contrast en de theorie omtrent het toetsen van hypothesen geven een nadere omschrijving van de manieren waarop prestaties en verwachtingen met elkaar kunnen worden vergeleken. De uitkomst van deze vergelijking is niet een simpele optel- of aftreksom, maar wordt beïnvloed door de manier waarop de vergelijking wordt gemaakt. Genoemde theorieën zullen nu kort worden toegelicht. 
Cognitieve dissonantietheorie of assimilatietheorie (Festinger, 1957 en Hovland et al., 1957).

Wanneer de perceptie van de produktprestatie niet overeenkomt met de verwachtingen, voorspelt de cognitieve dissonantietheorie dat er een psychologische spanning zal ontstaan. Deze spanning kan er toe leiden dat de consument zijn perceptie zal aanpassen, zodanig dat deze overeenkomt met zijn verwachtingen. Of dat de verwachtingen worden aangepast, zodanig dat deze overeenkomen met de perceptie. Hierdoor wordt de psychologische spanning geminimaliseerd ofwel geassimileerd en dus is de consument tevreden.

Voorbeelden van deze benadering zijn te vinden bij Olshavsky en Miller (1972), Anderson (1973) en Olson en Dover (1979).

Contrasttheorie (Dawes, Singer en Lemans, 1972).

De contrasttheorie voorspelt het tegenovergestelde van de cognitieve dissonantie- of assimilatie theorie; het verschil tussen de verwachtingen over een produkt en de feitelijke produktprestatie, zal tijdens de evaluatie worden vergroot. Dus als het produkt de verwachtingen slechts in geringe mate overtreft zal dit leiden tot een grote mate van tevredenheid (Cardozo, 1965; Howard en Sheth, 1969 en Engel en Blackwell, 1982).

Een voorbeeld van deze benadering is te vinden bij Cardozo (1965) en Anderson (1973).

\section{Gegeneraliseerde negativiteit}

Gegeneraliseerde negativiteit betekent, dat elke afwijking tussen verwachtingen en prestatie zal leiden tot een negatieve evaluatie. Zelfs wanneer de produktprestatie de verwachtingen overtreft, wordt dit als minder bevredigend ervaren dan wanneer de produktprestatie exact zou overeenkomen met de verwachtingen.

Een bevestiging van deze benadering is te vinden bij Carlsmith en Aronson (1963) en Oliver (1976).

Geassimileerd contrast (Sherif en Hovland, 1961).

Wanneer de verwachtingen over een produkt slechts weinig afwijken van de feitelijke prestatie van het produkt en het verschil tussen beide zich bevindt binnen de 'zone of indifference', zal het verschil tussen beide worden geassimileerd. Wanneer de verwachtingen over het produkt sterk afwijken van de feitelijke prestatie van het produkt en het verschil tussen beide zich bevindt in de 'zone of rejection', zal het verschil tussen beide extra worden benadrukt. Voorbeelden van deze benadering zijn te vinden bij Olshavsky en Miller (1972), Olson en Dover (1979) en Woodruff et al. (1983). Bij kleine afwijkingen is de consument tevreden; bij grote afwijkingen is de consument niet tevreden.

Involvement blijkt een belangrijke moderator-variabele te zijn die bepaalt of een verschil in perceptie van produktprestatie en verwachtingen wordt geassimileerd of gecontrasteerd (Sherif en Hovland, 1961). Consumenten met hoge involvement hebben een grote 'zone of rejection' en een kleine 'zone of acceptance'. Consumenten met een lage involvement hebben daarentegen een kleine 'zone of rejection' en een grote 'zone of acceptance' (Freedman, 1964; Sherif en Sherif, 1967 en Belonax en Javalgi, 1989). 
Het toetsen van hypothesen (Deighton, 1984).

Deze puur cognitieve benadering gaat ervan uit dat consumenten hypothesen vormen over produkten die gebaseerd zijn op reclame-uitingen. Consumenten proberen vervolgens zoveel mogelijk hun verwachtingen over een produkt te bevestigen wanneer zij met het produkt in aanraking komen. De mate waarin verwachtingen de perceptie van de produktprestatie beïnvloeden is met name afhankelijk van de ambiguïteit van de produktprestatie (Hoch en Ha, 1986). Hypothesen kunnen worden bevestigd of verworpen. Bevestiging van de hypothese betekent dat de consument tevreden is; verwerping van de hypothese betekent dat de consument niet tevreden is. (Er vanuit gaande dat de nulhypothese positief in termen van tevredenheid is geformuleerd.)

Anderson (1973) komt in zijn onderzoek tot de conclusie dat de theorie van assimilatiecontrast het beste voorspelt in vergelijking tot de cognitieve dissonantie theorie, de contrasttheorie en gegeneraliseerde negativiteit. In het onderzoek wordt gebruik gemaakt van een relatief eenvoudig produkt: een balpen. Anderson (1973) wijst er op dat, wanneer het gaat om meer complexe produkten waarbij een sterke mate van ambiguïteit bestaat en het moeilijker is om een oordeel te vormen, andere resultaten kunnen ontstaan. Olshavsky en Miller (1972), die het effect van over- en understatement van produktkwaliteit op de produkt-evaluatie hebben onderzocht, komen tot de conclusie dat de assimilatietheorie het beste voorspelt in vergelijking tot de andere theorieën hieromtrent. Het in hun onderzoek gebruikte produkt is meer complex: een cassette-recorder.

In de literatuur worden verschillende processen besproken die van invloed zijn op de manier waarop het verschil tussen prestatie en verwachtingen door een consument wordt verwerkt. Er bestaat geen eenduidig oordeel over welke theorie het beste kan worden gebruikt om de manier waarop de vergelijking wordt gemaakt, te verklaren. Het meest voor de hand ligt dat consumenten, net zoals zij verschillende vergelijkingsstandaarden gebruiken (zie paragraaf 2.3.3), ook verschillende vergelijkingsprocessen gebruiken afhankelijk van de persoon, het produkt en de situatie.

\subsubsection{Attributie}

Een andere factor die van invloed is op het ontstaan van tevredenheid is de attributie van de oorzaak van het verschil tussen verwachtingen over de produktprestatie en de feitelijke produktprestatie (attributietheorie: Heider, 1958; Weiner et al., 1971 en Weiner, 1985). Er wordt niet alleen gelet op het verschil tussen verwachtingen en produktprestatie, maar ook op de perceptie van de oorzaak van dat verschil: waar kan dat aan worden toegeschreven. (Voor voorbeelden van deze benadering zie Cohen en Goldberg, 1970; Folkes, 1984; Oliver, 1989; Oliver en DeSarbo, 1988 en Tse, 1990).

Binnen de attributietheorie worden drie causale dimensies onderscheiden: locus, stabiliteit en beheersbaarheid. Locus geeft aan wie als de oorzaak van het verschil tussen verwachtingen en produktprestatie gezien wordt: de consument of de aanbieder of het produkt. Wordt de consument zelf als oorzaak van het verschil gezien dan is er sprake van zogenaamde interne attributie. Wordt de aanbieder of het produkt als oorzaak van het verschil gezien dan is er sprake van exteme attributie. Stabiliteit heeft betrekking op de vraag of de oorzaak van het verschil tussen verwachtingen en produktprestatie van 
tijdelijke aard is of niet. Beheersbaarheid slaat op de mate waarin de consument het verschil tussen verwachtingen en produktprestatie onder controle heeft.

In een studie van Folkes (1984) wordt aangetoond dat met name locus en stabiliteit van invloed zijn op de verwachtingen over een produkt in de toekomst en dus op tevredenheid. Zowel locus, stabiliteit als beheersbaarheid blijken van invloed te zijn op de manier waarop een consument uiting geeft aan zijn/haar tevredenheid. Wanneer de oorzaak van de tevredenheid stabiel, beheersbaar en onder de controle van de consument is, zal tevredenheid bijvoorbeeld gemakkelijker leiden tot merktrouw dan wanneer de oorzaak van de tevredenheid instabiel, niet beheersbaar en niet onder de controle van de consument is.

Tse (1988) stelt voor niet langer gebruik te maken van de 'klassieke' attributie-dimensies van locus, stabiliteit en beheersbaarheid bij de verklaring van tevredenheid, maar deze dimensies te vervangen door 'product', 'consumption situation', 'consumer' en 'prior beliefs'. Het effect van deze vier causale dimensies op het gedrag na de aankoop is nog niet geheel duidelijk. Wel blijkt dat attributie van de oorzaak van het verschil tussen verwachtingen en produktprestatie aan de consumptie-situatie en 'prior beliefs' positief samenhangt met de mate van tevredenheid, attitude en intentie. Produkt en consument als causale dimensies blijken daarentegen geen rol te spelen bij de verklaring van het gedrag na de aankoop en tevredenheid.

Oliver en DeSarbo (1988) vinden dat de consument meer tevreden is indien hij/zij zichzelf ziet als de oorzaak van de tevredenheid dan wanneer de tevredenheid aan een ander (aanbieder) wordt toegeschreven.

Oliver (1989) benadrukt het belang van attributie voor de uiteindelijk ervaren tevredenheid naast het belang van de hieraan gekoppelde emoties (affect) en onderscheidt op basis hiervan verschillende prototypen van tevredenheid (zie paragraaf 2.5 ).

Kort samengevat kunnen we stellen dat de uitkomst van een subjectieve evaluatie of het gekozen alternatief overeenkomt met de verwachtingen van een subject over dat alternatief, of deze overtreft, volgens ons, tevredenheid is. Bij het ontstaan van tevredenheid spelen de verwachtingen ten aanzien van de produktprestatie, de feitelijke produktprestatie en de (dis)confirmatie een belangrijke rol. De consument kan de verwachtingen ten aanzien van de produktprestatie op verschillende standaarden baseren. De verwachte produktprestatie is echter de meest gebruikelijke. De perceptie van de feitelijke produktprestatie blijkt met name gebaseerd op de instrumentele prestatie van het produkt. De vergelijking tussen de verwachtingen over de feitelijke produktprestatie en de feitelijke produktprestatie wordt veelal subjectief verondersteld. Cognitieve dissonantietheorie, contrasttheorie, gegeneraliseerde negativiteit, geassimileerd contrast en het toetsen van hypothesen als mede attributietheorie bieden nader inzicht in de subjectieve vergelijkingsprocessen.

In het empirisch onderzoek staat niet het ontstaan van tevredenheid centraal, maar de uiteindelijk ervaren tevredenheid (de uitkomst van de subjectieve evaluatie). Daarom zal niet nader worden ingegaan op de 'problemen' en vraagtekens ten aanzien van de antecedenten van tevredenheid. 
Met name vanuit de psychologische benadering van tevredenheid zijn in de bestaande literatuur vele variabelen vermeld die bijdragen aan de verklaring van tevredenheid. Deze variabelen worden door ons geclassificeerd als persoonsgebonden variabelen. Deze persoonsgebonden variabelen zijn op de eerste plaats de verwachtingen over de produktprestatie, de produktprestatie en (dis)confirmatie. Maar ook involvement en ervaringen uit het verleden blijken een rol te spelen, terwijl de betekenis van socio-economische en demografische variabelen gering blijkt.

\subsubsection{Persoonsgebonden variabelen}

- verwachtingen, produktprestatie en (dis)confirmatie

De huidige literatuur toont aan dat zowel de verwachtingen over het produkt, de feitelijke produktprestatie als de positieve (dis)confirmatie van verwachtingen, direct en positief van invloed zijn op de mate van tevredenheid die een consument over een produkt ervaart. De verwachtingen en de produktprestatie zijn eveneens indirect van invloed op de mate van tevredenheid met als interveniërende variabele, confirmatie/disconfirmatie. In diverse onderzoeken is aangetoond dat de verwachtingen met betrekking tot een produkt direct van invloed zijn op de mate van ervaren tevredenheid (Cardozo, 1965; Day, 1977; Miller, 1977; Oliver, 1977 en 1980; Leichty en Churchill, 1979; Oliver en Linda, 1981; Bearden en Teel, 1983 en Woodruff, Cadotte en Jenkins, 1983). Ander onderzoek toont aan dat de produktprestatie direct van invloed is op de mate van tevredenheid/ontevredenheid (Olshavsky en Miller, 1972; Churchill en Surprenant, 1982; Wilton en Tse. 1983; Westbrook, 1987; Oliver en DeSarbo, 1988; Tse en Wilton, 1988 en Fornell, 1992). Dat disconfirmatie bepalend is voor de mate van ervaren tevredenheid, wordt aangegeven door Howard en Sheth (1969), Olshavsky en Miller (1972), Anderson (1973), Day (1977), Oliver (1977, 1980), LaTour en Peat (1979), Maddox (1981), Oliver en Linda (1981), Bearden en Teel (1983), Wilton en Tse (1983) en Woodruff, Cadotte en Jenkins (1983).

De indirecte invloed van de produktprestatie op tevredenheid via disconfirmatie alsmede de indirecte invloed van de verwachtingen op tevredenheid via disconfirmatie, is in vrijwel alle hier genoemde onderzoeken aangetoond.

Het volgende model (Figuur 2.2) geeft een weergave van de verklaring voor de mate van tevredenheid, gebaseerd op het disconfirmatie-paradigma. 


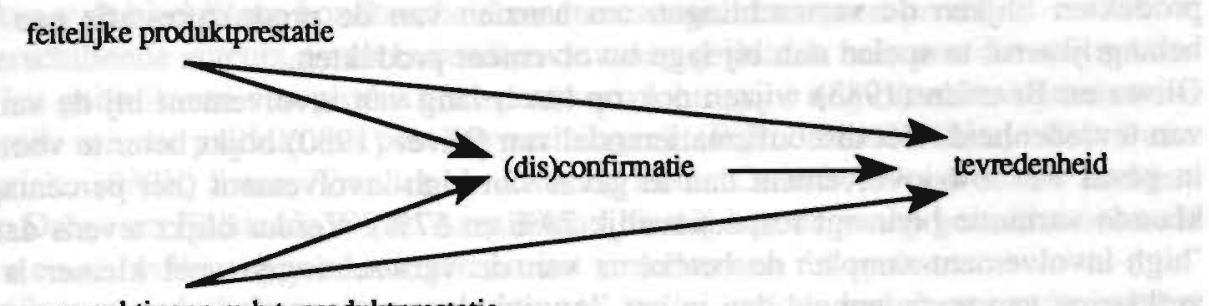

verwachtingen m.b.t. produktprestatie

Hoewel tevredenheid kan worden verklaard door de feitelijke produktprestatie, de verwachtingen met betrekking tot de produktprestatie en de (dis)confirmatie, zijn ook een aantal andere persoonsgebonden variabelen van invloed op het ontstaan van tevredenheid.

Aan deze variabelen zal nu aandacht worden besteed. In de eerste plaats wordt ingegaan op de manier waarop de mate van involvement van invloed is op de tevredenheid van de consument. Daarna wordt gekeken naar de betekenis van ervaringen uit het verleden. Tot slot van deze paragraaf zal de betekenis van socio-economische en demografische variabelen bij de verklaring van tevredenheid worden toegelicht. Daarmee zijn de persoonsgebonden variabelen besproken zoals deze in de literatuur zijn te vinden (voor markt- of economische variabelen wordt verwezen naar paragraaf 2.2).

\section{- involvement}

Tot nu toe is voornamelijk aandacht besteed aan de psychologische vergelijkings- of evaluatieprocessen die leiden tot tevredenheid met een produkt. Aan een belangrijk psychologisch construct dat eveneens van invloed is op het ontstaan van tevredenheid, is slechts zijdelings aandacht besteed: involvement. Involvement blijkt een rol te spelen bij de vorming van tevredenheid. Involvement bepaalt de grootte van de 'zone of acceptance' (Freedman, 1964 en Jacoby, 1971). De zone is smaller naarmate de involvement toeneemt (Sherif en Sherif, 1967 en Belonax en Javalgi, 1989). Dit betekent dat naarmate de involvement toeneemt eerder een verschil in verwachtingen en produktprestatie wordt geconstateerd en een consument duidelijker tevreden is wanneer de produktprestatie de verwachtingen overtreft of er mee overeenkomt. Maar het betekent ook dat naarmate de involvement toeneemt, de consument duidelijker niet tevreden is, wanneer de produktprestatie slechter is dan de verwachting. De kans op disconfirmatie stijgt bij het toenemen van de involvement. Waarbij uiteraard rekening moet worden gehouden met het door de consument gemaakte vergelijkings- of attributieproces.

Het bekende onderscheid tussen high- en low-involvement produkten wordt ook met betrekking tot het verklaren van tevredenheid geconstateerd. Swan en Trawick (1979) stellen vast dat de mate waarin een produkt geëvalueerd wordt (als indicator van de mate van involvement), afhankelijk is van de produktklasse; des te groter de involvement, hoe uitgebreider de evaluatie. Zij stellen tevens, dat elke produktklasse een verschillend niveau van involvement vertegenwoordigt. De verschillen in de mate van produktevaluatie in de verschillende produktklassen leiden tot het formuleren van ver- 
schillende modellen om de mate van tevredenheid te bepalen. Bij hoge involvement produkten blijken de verwachtingen ten aanzien van de produktprestatie een minder belangrijke rol te spelen dan bij lage involvement produkten.

Oliver en Bearden (1983) wijzen ook op het belang van involvement bij de verklaring van tevredenheid. Het disconfirmatiemodel van Oliver (1980) blijkt beter te voorspellen in geval van low-involvement dan in geval van high-involvement (het percentage verklaarde variantie bedraagt respectievelijk $79 \%$ en $57 \%$ ). Verder blijkt tevens dat in het 'high-involvement-sample' de betekenis van de verwachtingen veel kleiner is bij de verklaring van tevredenheid dan in het 'low involvement sample'.

Day (1977) stelt zelfs dat consumenten in het geheel geen evaluatie maken van eenvoudige (low-involvement) produkten. Engel et al. (1986, p. 157) stellen dat "... satisfaction builds on a conscious and deliberate evaluation of outcomes. As would be expected, the strength of reaction is much greater when there is a high degree of involvement".

Churchill en Surprenant (1982) introduceren de aard van het produkt (duurzaam versus niet duurzaam) als een determinant van het model ter verklaring van tevredenheid. Bij het gebruik van hetzelfde model worden voor twee verschillende produkten verschillende resultaten gevonden voor wat betreft het effect van disconfirmatie op tevredenheid. Voor het niet duurzame produkt worden resultaten gevonden zoals verwacht: produktprestatie en verwachtingen bepalen de disconfirmatie, deze disconfirmatie is bepalend voor de mate van tevredenheid. Dit sluit goed aan bij het disconfirmatie model van Oliver (1980). Voor het duurzame produkt zijn de resultaten afwijkend in die zin, dat blijkt dat disconfirmatie en verwachtingen niet of nauwelijks van invloed zijn op de tevredenheid. In dit geval wordt de tevredenheid eigenlijk alleen bepaald door de produktprestatie.

Hoewel het onderscheid duurzaam/niet-duurzaam niet geheel overeenkomt met het onderscheid tussen high- en low-involvement, zijn de resultaten van dit onderzoek in overeenstemming met de bevindingen uit onderzoeken waarin wel een onderscheid wordt gemaakt tussen high- en low-involvement.

Samengevat betekent bovenstaande, dat de mate van tevredenheid en de manier waarop tevredenheid verklaard kan worden afhankelijk is van de mate van involvement. Ons inziens moeten op basis van de mate van involvement verschillende soorten tevredenheid worden onderscheiden omdat er aanleiding is te veronderstellen dat een produkt in geval van high-involvement anders wordt geëvalueerd dan in geval van low-involvement. Hierop zal in hoofdstuk 3 nader worden ingegaan.

\section{- ervaringen uit het verleden}

Dat tijd een factor is die van invloed is op de verklaring van tevredenheid, is pas recentelijk onderkend. Bij het meeste onderzoek uit het verleden werd alleen gelet op de disconfirmatie en de tevredenheid die direct volgen op het eenmalige gebruik van een produkt. Meermalig gebruik van een produkt over langere tijd, wordt niet in beschouwing genomen. Vooral bij high-involvement produkten, complexe produkten en duurzame produkten zal de tijd van invloed zijn op de mate van tevredenheid. Tevredenheid kan zich wijzigen in de loop van de tijd als gevolg van het voortdurende gebruik van het produkt of als gevolg van het feit, dat het belang van de consument bij het produkt 
verandert. Een ander aspect is, dat bepaalde attributen pas op termijn te beoordelen zijn. Te denken valt hierbij aan houdbaarheid en duurzaamheid van een produkt.

Door verschillende auteurs wordt bovendien de vraag gesteld in hoeverre de verwachtingen na het gebruik van een produkt (ex post verwachtingen) nog dezelfde zijn als voor het gebruik van dat produkt (ex post verwachtingen). (Bijvoorbeeld Miller, 1976; Swan en Trawick, 1980b; Swan, Trawick en Carroll, 1982; Cadotte, Woodruff en Jenkins, 1987 en Dröge en Halstead, 1991). Aansluitend hierbij kan de vraag gesteld worden in hoeverre en op welke wijze ervaringen uit het verleden een rol spelen.

Belangrijk is te onderkennen dat verwachtingen, onder invloed van de prestatie van het produkt en de perceptie van de produktprestatie kunnen wijzigen in de loop van de tijd (adaptatie van de verwachtingsstandaard). Er kan verondersteld worden dat sprake is van een voortdurende interactie tussen verwachtingen en produktprestatie als gevolg van reductie van cognitieve dissonantie, informatieverzameling en rationalisatie (Miller, 1976).

Oliver (1980) gaat er op grond van de adaptatieniveau-theorie van Helson (1964) inderdaad vanuit, dat de verwachtingen over de prestatie van een produkt zich in de loop der tijd voortdurend aanpassen aan de ervaringen met het produkt.

Het voortschrijden van de tijd is een factor die van invloed is op de mate van tevredenheid. Na verloop van tijd kan de tevredenheid met een produkt veranderen. Tevredenheid is dus geen statische afhankelijke van een enkele consumptie-ervaring maar een dynamisch fenomeen.

\section{- socio-economische en demografische variabelen}

Day en Bodur (1977) correleren verschillende demografische variabelen met tevredenheidsscores betreffende verschillende soorten reparaties en andere diensten. Zij vinden dat demografische factoren slechts zwak gerelateerd zijn aan tevredenheidsscores. Grönhaug (1977) rapporteert eveneens lage correlatie-coëfficiënten tussen enerzijds leeftijd, opleiding, inkomen, woonplaats, type arbeid (witte/blauwe boorden) en werken buitenshuis en anderzijds de tevredenheid met melk, vlees, koffie, groente, textiel en auto's. Pfaff en Blivice (1977) constateren in hun onderzoek dat één-derde van de variantie van tevredenheid met voedingsmiddelen wordt verklaard door socio-economische factoren; tevredenheid neemt over het algemeen af met het toenemen van de grootte van het huishouden en het niveau van de opleiding en de tevredenheid neemt over het algemeen toe met het dalen van de leeftijd. In een andere studie vinden zij dat mannen in het algemeen vaker tevreden zijn met diverse produkten dan vrouwen. Hierbij aansluitend rapporteren Duhaime en Ash (1980) dat mannen als consumenten van auto's, andere transportmiddelen en financiële diensten, relatief meer tevreden zijn dan vrouwen.

Deze studies zijn een indicatie om een zwakke relatie tussen de afzonderlijke socioeconomische en demografische variabelen en tevredenheid te veronderstellen.

Francken en Van Raaij (1985) concluderen ons inziens terecht dat de verklarende kracht van socio-economische en demografische variabelen bij tevredenheid uiterst gering is. $\mathrm{Zij}$ wijzen erop dat de verklaringskracht van deze variabelen zou kunnen toenemen wanneer niet alleen maar wordt gecontroleerd voor het soort produkt, maar ook voor het soort probleem dat met een produkt wordt ondervonden. Analoog aan de bevindingen van Andreasen (1985) zouden socio-economische en demografische variabelen een 
betere voorspelling kunnen opleveren indien wordt gecontroleerd voor de probleemperceptie van de consument. Deze probleemperceptie is naar alle waarschijnlijkheid mede afhankelijk van het inkomen van de consument. Daarnaast zou dan wellicht ook gecontroleerd moeten worden voor de situatie waarin het produkt wordt geconsumeerd of het domein waarbinnen het produkt wordt gebruikt (Van Raaij en Verhallen, 1990).

Tevredenheid kan op de eerste plaats worden verklaard door de feitelijke produktprestatie, de verwachtingen met betrekking tot de produktprestatie en (dis)confirmatie. Ook involvement blijkt een rol te spelen bij de verklaring van tevredenheid, al is de specifieke betekenis tot nu toe nog onduidelijk. Wij zullen in hoofdstuk 3 nader aandacht aan de rol van involvement schenken. Tot slot dragen ervaringen uit het verleden, via de vorming van verwachtingen, mede bij aan de verklaring van tevredenheid. $\mathrm{Er}$ is geen reden om te veronderstellen dat socio-economische en demografische variabelen direct van belang zijn bij de verklaring van tevredenheid.

\section{$2.5 \quad$ Affect}

In het disconfirmatie-paradigma staat de cognitieve benadering van tevredenheid centraal. Al in 1977 stelt Pfaff echter dat tevredenheid zowel beschreven kan worden door affectieve modellen als door cognitieve modellen. Desalniettemin wordt in de meeste modellen, tot het midden van de jaren ' 80 , steeds de nadruk gelegd op cognitie (Oliver, 1980; Bearden en Teel, 1983; LaBarbera en Mazursky, 1983 en Richins, 1983). Anderen wijzen echter op de betekenis van affect bij de verklaring van tevredenheid (La Tour en Peat, 1979; Westbrook en Reilly, 1983; Woodruff, Cadotte en Jenkins, 1983; Holbrook, 1984; Westbrook, 1987; Oliver, 1989 en Dubé en Schmitt, 1991).

LaTour en Peat (1979) benadrukken deze betekenis van affect door er op te wijzen dat wanneer een consument 'gedwongen' wordt een produkt te kopen waar zijn/haar voorkeur bepaald niet naar uit gaat, het goed mogelijk is dat verwachtingen en produktprestatie perfect met elkaar in overeenstemming zijn of zelfs dat de produktprestatie de verwachtingen nog overtreft. Deze consument zal toch niet tevreden zijn met zijn/haar aankoop omdat het gevoel bij de aankoop niet positief was.

Westbrook (1987) gaat na of - en zo ja welke - rol affect speelt bij de verklaring van tevredenheid. Hierbij wordt een onderscheid gemaakt tussen negatief en positief affect. Geconcludeerd wordt dat tevredenheid niet alleen wordt bepaald door cognitieve vergelijkingsprocessen, maar dat affectieve processen zouden moeten worden toegevoegd voor een betere verklaring van tevredenheid. Positief affect verhoogt namelijk de mate van tevredenheid.

Oliver (1989) stelt een 'nieuw' cognitief/affectief model voor om de relatie tussen produktprestatie en verwachtingen aan de ene kant en tevredenheid aan de andere kant, weer te geven. De vergelijking tussen produktprestatie en verwachtingen staat nog steeds centraal. Het model wordt uitgebreid in die zin dat disconfirmatie van verwachtingen aanleiding zal zijn tot attributie-processen. Als gevolg van deze attributie-processen, is niet alleen een primair affect (happy/sad) als resultaat van een primaire evaluatie (success/failure) bepalend voor de mate van tevredenheid. Ook een secundair effect (distinct emotions) als resultaat van de attributie, draagt bij aan de mate van tevreden- 
heid. Volgens Oliver (1989) betekent dit, dat een gelijk niveau van disconfirmatie afhankelijk van de gemaakte attributie en de soort affect - tot verschillende prototypen van tevredenheid kan leiden. Voorbeelden in dit verband zijn: 'satisfaction as contentment', 'satisfaction as pleasure or relief', 'satisfaction as novelty' en 'satisfaction as surprise'.

Westbrook en Oliver (1991) stellen vast dat aan identieke uitingen van tevredenheid verschillende emoties ten grondslag kunnen liggen. Een grote mate van tevredenheid kan bijvoorbeeld gebaseerd zijn op "pleasure linked to surprise over the consumption experience and pleasure coupled with high interest" (p.89). Verschillende emoties zijn dus de basis voor het ontstaan van verschillende prototypen tevredenheid.

Bij het opstellen van onderzoeksmodellen ter verklaring van tevredenheid zal in de toekomst, naar onze mening, een prominentere plaats moeten worden ingeruimd voor 'affect' dan tot nu toe het geval is geweest. Een verklaring die alleen maar gebaseerd is op het onderzoek naar cognitieve aspecten zal, naar wij verwachten, steeds vaker onvoldoende blijken. Daamaast lijkt het ons zinvol om duidelijke differentiaties tussen de prototypen van tevredenheid aan te brengen. In het empirisch onderzoek zullen wij niet expliciet aandacht besteden aan de cognitieve en affectieve aspecten van tevredenheid, noch aan de verschillende prototypen. Voor ons staat het uiteindelijke tevredenheidsoordeel centraal, waarin verschillende componenten vertegenwoordigd kunnen zijn.

\subsection{Operationalisatie van tevredenheid}

\subsubsection{Taxonomie van metingen}

Andreasen (1977) geeft een taxonomie van metingen van consumententevredenheid. Hij onderscheidt drie verschillende dimensies aan de hand waarvan de verschillende meetprocedures kunnen worden ingedeeld:

1 het onderwerp: 'maximizing' (tevredenheid) of 'minimizing' (ontevredenheid);

2 de methode: subjectieve of objectieve meting;

3 het tijdstip: voor of na het moment dat de leverancier/verkoper in staat is gesteld iets aan het probleem te doen (aanvankelijk versus uiteindelijk).

De meeste metingen van consumenten(on)tevredenheid die worden verricht vallen in de volgende twee categorieën:

\section{Objectieve indicatoren van uiteindelijke tevredenheid}

Voorbeelden zijn verkochte hoeveelheden, marktaandelen, herhalingsaankopen en merktrouw. Deze metingen worden vooral in het bedrijfsleven gehanteerd. De belangrijkste beperking van deze indicatoren is dat, ons inziens onterecht, een direct en eenduidig verband verondersteld wordt tussen bijvoorbeeld merktrouw en tevredenheid (merktrouw en tevredenheid zijn zo twee verschillende concepten die op dezelfde wijze geoperationaliseerd worden).

De beperkingen van deze benadering die gebruikelijk in de literatuur genoemd worden, zijn dat achteraf wordt gemeten, zodat gegevens laat worden verkregen (vooral 
bij duurzame consumptiegoederen) en dat veel verstorende factoren kunnen optreden (bijvoorbeeld concurrentie). Ook een algemene index van consumententevredenheid kan onder de objectieve indicatoren van uiteindelijke tevredenheid worden gerangschikt. Voor beleidsdoeleinden kan zo'n index weliswaar nuttig zijn (vergelijk dit met bijvoorbeeld het prijsindexcijfer of de index voor consumentenvertrouwen), maar voor het verklaren van gedrag is zo'n index te globaal en te generaliserend. Dit vereist meer specifieke metingen op individueel niveau, zoals deze in de volgende categorie worden weergegeven.

2 Subjectieve indicatoren van aanvankelijke tevredenheid

Voorbeeld zijn de tevredenheidsschalen zoals die veelvuldig door marktonderzoekbureaus worden gebruikt, zoals de 5-punts schaal (always satisfied - never satisfied), de 4-punts schaal en de procentschaal van Westbrook (1981). Deze schalen hebben als bezwaar dat zij geen rekening houden met het kennisniveau van de consument, de betrokkenheid bij het produkt en de invloed van situationele factoren. Desalniettemin zijn deze schalen een goede indicator van de door de individuele consument ervaren tevredenheid.

Hausknecht (1990) komt met een ander soortige taxonomie van metingen. De verschillende door de tijd gehanteerde maten van tevredenheid worden langs twee dimensies ingedeeld:

1 cognitieve, affectieve en conatieve maten (wat);

2 verbale en grafische schaal structuur (hoe).

Hausknecht stelt, dat de meest recente en op dit moment meest gehanteerde maten van tevredenheid uitgaan van een tevredenheidsconcept waarbij de nadruk ligt op affect in plaats van cognitie. Dit sluit aan bij de geconstateerde ontwikkeling in de theorievorming over tevredenheid. Voorbeelden van de meer op het affect gerichte operationalisatie van tevredenheid zijn te vinden bij o.a. Oliver en Westbrook, (1980); Westbrook en Oliver, (1980); Swan, Trawick en Carroll, (1981); Churchill en Surprenant, (1982); Oliver en Bearden, (1983) en Westbrook, (1987).

Olander (1977) waarschuwt voor het nastreven (en dus het meten van) tevredenheid; een consument is tevredener naarmate hij/zij minder weet, minder eist en minder verwacht. Dit kan echter nooit tot de hoofddoelstellingen van een consumentenbeleid behoren.

\subsubsection{Dimensionaliteit van de meting}

Zijn tevredenheid en ontevredenheid twee verschillende concepten of zijn het twee zijden van dezelfde medaille? Moeten tevredenheid en ontevredenheid op eén continuüm worden geplaatst of moeten twee verschillende continua worden onderscheiden.

Op de eerste plaats moet opgemerkt worden dat de literatuur ons inziens op dit punt geen duidelijkheid verschaft.

Herzberg et al. (1959, p. 108) merken op: "The opposite of job satisfaction is not job dissatisfaction but, rather no job satisfaction; and, similarly, the opposite of job dissatisfaction is not job satisfaction but no job dissatisfaction". Bij de tevredenheid met produkten doet zich dit probleem evenzo voor (Leavitt, 1977). 
Tevredenheid is in de loop der tijd geoperationaliseerd op schalen die lopen van geheel niet tevreden tot zeer tevreden (bijvoorbeeld Westbrook, 1981) en op schalen die lopen van zeer ontevreden tot zeer tevreden (bijvoorbeeld Oliver en Linda, 1981). Een duidelijke voorkeur, dus voor een één- of een twee dimensionele opvatting, valt in dit opzicht, tot op heden, niet te ontdekken.

Dröge en Halstead (1991) tonen aan dat tevredenheid en ontevredenheid verschillend moeten worden verklaard. Genoemde auteurs vinden namelijk een verschil in de verklaring van tevredenheid tussen klagers en niet-klagers. Hierbij wordt ervan uitgegaan dat de groep klagers bestaat uit ontevreden consumenten en de groep niet-klagers bestaat uit zowel ontevreden als tevreden consumenten. Het blijkt dat voor niet-klagers de verwachtingen minder bijdragen aan de verklaring van tevredenheid dan voor klagers. Tevens blijkt dat voor niet-klagers disconfirmatie meer bijdraagt aan de verklaring van tevredenheid dan voor klagers. Uit de studie kan afgeleid worden dat verwachtingen voor tevreden consumenten een minder belangrijke rol spelen dan voor ontevreden consumenten. Een verklaring hiervoor kan gelegen zijn in het feit dat bij tevreden consumenten aanvankelijke en afgeleide verwachtingen goed met elkaar overeen komen, maar dat voor ontevreden consumenten daartussen een verschil bestaat.

In de literatuur wordt er veelal vanuit gegaan dat tevredenheid - ontevredenheid als één dimensie kan worden weergegeven. Echter, gegeven de twee-factoren theorie van Herzberg en het feit dat tevredenheid en ontevredenheid verschillend verklaard worden en over het algemeen verschillende gevolgen hebben is voor ons aanleiding tevredenheid en ontevredenheid op te vatten als twee afzonderlijke dimensies die niet op én continuüm bijeen mogen worden gebracht.

\subsubsection{Specificiteit van de meting}

Kan tevredenheid direct op overall-niveau worden gemeten (Hoe tevreden bent $u$ met produkt X?) of moet de tevredenheid per attribuut worden vastgesteld (Hoe tevreden bent $\mathrm{u}$ met de smaak van produkt $X$ ?). In het laatste geval moet de tevredenheidsscore op de afzonderlijke attributen op de een of andere wijze worden gesommeerd om een alles omvattend oordeel over de tevredenheid met het produkt te verkrijgen.

In de literatuur wordt er veelal van uitgegaan dat tevredenheid direct op produktniveau kan worden gemeten. Ook al omdat zich dan geen aggregatie-probleem over de verschillende attributen voordoet (Hausknecht, 1990). Bovendien geldt dat de totale tevredenheid meer is dan de som der delen (zie paragraaf 2.3.5 over het 'voordeel' van de subjectieve disconfirmatie benadering boven de subtractieve disconfirmatie benadering).

\subsubsection{Kanttekeningen bij het meten van tevredenheid}

Peterson en Wilson (1992) constateren evenals Hunt (1977), Oliver (1981) en LaBarbera en Mazursky (1983), dat in onderzoek veelal een scheve verdeling voor tevredenheid wordt gevonden, die positief is gebiased (negatively skewed and positively biased). Volgens deze auteurs zijn naast het 'Hawthome effect' (het feit dat consumenten weten dat ze bestudeerd worden maakt dat zij zich anders gaan gedragen) een aantal oorzaken aan te wijzen voor dit fenomeen. Ten eerste: welke rationele consument consumeert 
willens en wetens een produkt waarvan bij voorbaat vaststaat dat hij/zij er ontevreden mee zal zijn? Ten tweede wordt tevredenheid beïnvloed door verwachtingen en percepties. De vorming van tevredenheid vereist de nodige cognitieve inspanning. De verschillende antecedenten van tevredenheid kunnen hierdoor een oorzaak zijn van de scheve verdeling (zie ook Anderson, 1973; Oliver, 1980; Bearden en Teel, 1983 en Cadotte, Woodruff en Jenkins, 1987). Ten derde kan verondersteld worden dat tevredenheid nu eenmaal door een scheve verdeling wordt gekenmerkt. Tot slot zou een verklaring van de scheve verdeling gelegen kunnen zijn in het feit dat deze het gevolg is van de methodologie van onderzoek en eigenlijk een artefact vertegenwoordigt. Geen van de genoemde oorzaken kan bij voorbaat worden uitgesloten. De methodologische oorzaken kunnen echter wel nader worden uitgewerkt. Zo kan er een onderscheid worden gemaakt naar Peterson en Wilson (1992):

1 'ceiling' effect

Er worden onvoldoende antwoordmogelijkheden aangeboden aan de respondent. Dit effect kan worden aangetoond als oorzaak van de scheve verdeling van antwoorden;

2 'response bias'

Tevreden consumenten nemen sneller aan onderzoek deel dan ontevreden consumenten. Dit effect kan empirisch niet worden aangetoond in de studie van Peter en Wilson;

3 data collectie methode

Er wordt aangetoond, dat bij persoonlijke enquêtes een schevere verdeling wordt aangetroffen dan bij telefonische of schriftelijke enquêtes;

4 vraagformulering

Wanneer vragen worden geformuleerd in termen van tevredenheid wordt een schevere verdeling aangetroffen dan wanneer vragen worden geformuleerd in termen van ontevredenheid;

5 context van de vraag

Bij vragen vooraan in de vragenlijst wordt een positief schevere verdeling gevonden dan bij vragen verderop in de vragenlijst;

6 tijdstip van ondervraging

Het tijdstip van ondervraging lijkt van invloed te zijn op de scheefheid van de verdeling van de tevredenheidsscores. Echter er bestaat nog grote onduidelijkheid of het effect groter is direct na de aankoop of op een later tijdstip. Dit hangt samen met de onduidelijkheid omtrent het ideale moment waarop tevredenheid moet worden gemeten;

7 sociale wenselijkheid, accuraatheid van de antwoorden en stemming

Deze factoren spelen eveneens een rol bij het veroorzaken van een scheve verdeling.

Het feit de verdeling van de maat van tevredenheid schever is bij persoonlijke enquêtes in tegenstelling tot telefonische of schriftelijke enquêtes en schever is bij vragen verderop in de vragenlijst zou, volgens ons, te maken kunnen hebben met de betrokkenheid van de respondent. Deze is vaak kleiner bij schriftelijke en telefonische enquêtes dan bij persoonlijke enquêtes en neemt ook vaak af naarmate de vragenlijst langer is.

Gevolg van de scheve verdeling van tevredenheid is dat gemiddelde tevredenheid weinig zegt en dat een onderschatting van de correlatie van tevredenheid en andere variabelen kan optreden (Peterson en Wilson, 1992). 
Tevredenheid kan zowel vanuit een economisch perspectief als vanuit een economischpsychologisch perspectief worden bestudeerd. Uitgaande van het economisch perspectief is aandacht besteed aan de karakteristiekentheorie, de hedonistische prijstheorie en het 'market level model' van Fomell en Robinson, de transactiekostentheorie en de index van consumententevredenheid.

Ons inziens is het niet mogelijk via de economische benadering van tevredenheid voldoende empirisch inzicht te verwerven in de antecedenten en met name de consequenties (o.a. merktrouw) van tevredenheid op individueel niveau.

Ons inziens biedt een benadering waarbij rekening wordt gehouden met een economisch en een psychologisch perspectief, de beste mogelijkheden om inzicht te verkrijgen in de verschillende antecedenten en consequenties van tevredenheid. Gezien het feit, dat in de literatuur nog niet veel aandacht is gegeven aan deze (complexe) benadering, staat vervolgens de economisch-psychologische benadering centraal. Deze is in de consumentengedrags literatuur sterk vertegenwoordigd.

Uitgaande van deze economisch-psychologische benadering wordt tevredenheid, door ons, gedefinieerd als de uitkomst van een subjectieve evaluatie of het gekozen alternatief $(=$ produkt/merk) overeenkomt met de verwachtingen van een subject over dat alternatief, of deze overtreft. Mede vanuit deze defintie staat het 'two stage expectancy confirmation model' van Oliver centraal. Dit model beschrijft het disconfirmatie paradigma en de antecedenten en consequenties van tevredenheid. In het eerste gedeelte van het model wordt aangegeven, dat de vergelijking tussen de verwachtingen over de produktprestatie en de feitelijke produktprestatie, via (dis)confirmatie, oorzaak is van het ontstaan van tevredenheid. In het tweede gedeelte wordt beschreven hoe tevredenheid van invloed is op attitudes en gedragsintenties.

Verwachtingen over een produkt kunnen op verschillende manieren worden gevormd. Ze kunnen gebaseerd zijn op een billijke prestatie, een ideale prestatie, een verwachte prestatie, een minimale prestatie, op waarden, wensen en normen. Uit onderzoek blijkt dat verschillende soorten verwachtingen in combinatie worden gebruikt als het gaat om de vergelijking met de produktprestatie. Uiteraard worden verwachtingen beïnvloed door ervaringen uit het verleden en de communicatie (van de aanbieder en mede-consumenten).

De produktprestatie kan onderscheiden worden naar instrumentele prestatie en expressieve prestatie. De instrumentele prestatie van een produkt blijkt het belangrijkste te zijn daar waar het gaat om de verklaring van tevredenheid.

In de literatuur worden twee benaderingen aangaande de (dis)confirmatie aangetroffen: de subtractieve benadering en de subjectieve benadering. Bij de subtractieve benadering wordt ervan uitgegaan dat de effecten van de vergelijking tussen de verwachtingen en de prestatie op allerlei attributen kunnen worden weergegeven als een rekenkundige functie. Bij de subjectieve benadering wordt er daarentegen van uitgegaan dat een afzonderlijk psychologisch construct een subjectieve evaluatie weergeeft van het verschil tussen verwachtingen en prestatie in z'n totaliteit waarbij 'het totaal meer is dan de som 
der delen'. Uit de literatuur blijkt dat de subjectieve benadering de voorkeur geniet boven de subtractieve benadering.

De manier van vergelijken van de verwachtingen over een produkt en de prestatie van het produkt zelf kan worden beïnvloed door cognitieve dissonantie, maar ook door het stellen van contrasten (contrasttheorie of geassimileerde contrasttheorie) en gegeneraliseerde negativiteit. Deze benaderingen zorgen voor een verschillend effect (vergroting en/of verkleining) op het verschil dat wordt waargenomen tussen de verwachtingen en de prestatie. Geassimileerd contrast (kleine verschillen worden verkleind, grote verschillen vergroot) lijkt een goede verklaring te geven voor het voorspellen van de mate van tevredenheid. De attributie van de oorzaak van het verschil tussen verwachtingen en prestaties speelt eveneens een rol bij de verklaring van de mate van tevredenheid.

Tevredenheid kan worden verklaard op grond van verwachtingen, produktprestatie, disconfirmatie en attributie, maar ook andere persoonsgebonden variabelen spelen er een rol bij.

Involvement bij het produkt beïnvloedt de tevredenheid in die zin, dat bij lage involvement een produkt nauwelijks (of in ieder geval anders) wordt geëvalueerd, wat bij hoge involvement wel het geval is. Bovendien wordt bij een toenemende involvement eerder een verschil tussen verwachtingen en produktprestatie geconstateerd.

Tijd kan van invloed zijn op tevredenheid doordat bepaalde attributen van produkten soms pas in de loop der tijd te beoordelen zijn. De ervaringen uit het verleden beïnvloeden, via de verwachtingen over de produktprestatie, de huidige tevredenheid.

Socio-economische en demografische factoren blijken niet rechtstreeks bij te kunnen dragen aan de verklaring van tevredenheid. Waarschijnlijk moet worden gecontroleerd voor de situatie waarin het produkt wordt gebruikt of de probleemperceptie van de consument.

Op basis van affect kunnen verschillende prototypen van tevredenheid (zoals 'satisfaction as pleasure or relief') worden onderscheiden. De precieze betekenis van affect bij het ontstaan van tevredenheid is tot nu niet uitgebreid onderzocht.

Tevredenheid kan op zeer veel verschillende manieren worden geoperationaliseerd. Er kan een onderscheid worden gemaakt naar onderwerp (tevredenheid versus ontevredenheid); methode (objectief versus subjectief) en naar tijdstip (voor of na het moment dat de leverancier/verkoper in de gelegenheid is gesteld iets aan een probleem te doen). Daarnaast kan een onderscheid worden gemaakt tussen cognitieve, affectieve en conatieve maten enerzijds en verbale en grafische maten anderzijds. Momenteel wordt tevredenheid vooral gemeten met maten waarin het affectieve aspect van tevredenheid duidelijk aan de orde komt.

Tevredenheid en ontevredenheid kunnen worden gezien als twee uiteinden van éen continuüm of als twee onafhankelijke concepten. In de literatuur worden beide visies verdedigd. Wij geven er de voorkeur aan om tevredenheid en ontevredenheid op te vatten als twee afzonderlijke concepten.

Tevredenheid kan heel specifiek op micro niveau worden gemeten (tevredenheid van een consument met een produkt) of globaal en op macro-niveau (verkoopcijfers). Wanneer op micro-niveau wordt gemeten kan voor tevredenheid, ons inziens, het beste per 
produkt met een overall tevredenheidsscore worden gewerkt en niet met allerlei verschillende attribuutscores. Tot slot wordt opgemerkt, dat tevredenheid in onderzoek wordt gekenmerkt door een scheve verdeling.

Vanuit de economische en de economisch-psychologische benadering van tevredenheid zijn in dit hoofdstuk een groot aantal variabelen aan de orde geweest die kunnen bijdragen aan de verklaring ervan. In Schema 2.1 geven wij een overzicht van deze variabelen, ingedeeld naar persoonsgebonden variabelen en marktvariabelen.

Schema 2.1: Verklarende variabelen voor tevredenheid

\section{Persoonsgebonden variabelen}

Psychologische produktvariabelen

- verwachtingen over produkt

- produktprestatie

- confirmatie

- positieve disconfirmatie

- negatieve disconfirmatie

- involvement

- ervaringen uit het verleden

Socio-economische-, demografische en persoonlijkheidsvariabelen

- algemeen

\section{Gebruiksvariabelen}

- situatie produktgebruik

- probleem dat wordt ondervonden

- domein produktgebruik

\section{Marktvariabelen}

- concentratiegraad

- distributiespreiding

- consumentenkosten

- transactiekosten

- heterogeen produkt, heterogene markt

- afhankelijkheid tevredenheid

- hedonistische prijs

\author{
positief \\ positief \\ positief \\ positief \\ negatief \\ ?* \\ ?
}

Relatie met tevredenheid

geen\#

situatie specifiek

probleem specifiek

domein specifiek

geen
negatief prijs/positief $\mathrm{kwaliteit}$
negatief prijs en kwaliteit
negatief
positief
positief
?

*: onduidelijk verband tussen variabele en tevredenheid; \#: geen verband tussen variabele en tevredenheid 
In het literatuuroverzicht over merktrouw is de relatie tussen merktrouw en tevredenheid aan de orde geweest (paragraaf 1.5.1). Hierdoor is duidelijk geworden dat tevredenheid een positieve rol speelt bij de verklaring van merktrouw. De exacte rol van tevredenheid is echter onduidelijk, omdat, in het meeste onderzoek, geen duidelijk onderscheid is gemaakt tussen ware merktrouw en herhalingsaankopen en omdat geen aandacht is besteed aan die variabelen, die de rol van tevredenheid bij de verklaring van ware merktrouw beïnvloeden.

Alvorens in te gaan op de rol die tevredenheid speelt bij de verklaring van ware merktrouw, wordt een overzicht gegeven van de belangrijkste overeenkomsten tussen beide concepten in termen van theoretische, methodologische en praktische aspecten. Vervolgens worden, bij elk van de concepten afzonderlijk, een aantal kritische kanttekeningen geplaatst. Naar aanleiding van deze kritische kanttekeningen, wordt een (alternatieve) visie op de verklaring van ware merktrouw en de rol van tevredenheid daarbij gepresenteerd. De betekenis van tevredenheid bij de verklaring van ware merktrouw is volgens ons afhankelijk van de motivatie en de capaciteit van de consument om de merkkeuze te evalueren. Aan het einde van dit hoofdstuk zal het onderzoeksmodel met de bijbehorende hypothesen worden weergegeven. In aansluiting hierop zal kort aandacht worden besteed aan bestaand onderzoek naar de rol van tevredenheid bij de verklaring van ware merktrouw.

\subsection{Merktrouw en tevredenheid: een eerste inzicht in de samenhang}

Vanuit de doelstelling van dit onderzoek is gekozen voor een economisch-psychologische benadering van ware merktrouw en tevredenheid. Dit heeft er toe geleid dat ware merktrouw wordt gedefinieerd in termen van gedrag gebaseerd op commitment en tevredenheid gedefinieerd wordt in termen van een evaluatieproces. De economomischpsychologische benadering van ware merktrouw sluit goed aan bij de economischpsychologische benadering van tevredenheid. Zowel bij ware merktrouw als bij tevredenheid spelen namelijk, naar onze opvatting, evaluatieprocessen een belangrijke rol.

Ware merktrouw en tevredenheid kunnen beide opgevat worden als de uitkomst van een proces. Ware merktrouw is het opnieuw kopen van een bepaald merk gebaseerd op commitment en tevredenheid resulteert uit het proces van het evalueren van het gekochte merk. Gezien de doelstelling van het onderzoek, wordt tevredenheid door ons opgevat als de uitkomst van het evaluatieproces (tevredenheid is een verklarende variabele in de relatie tussen tevredenheid en ware merktrouw). De reden hiervoor is dat niet de antece- 
denten, maar een consequentie van tevredenheid, namelijk ware merktrouw, in dit onderzoek centraal staat.

In het literatuuroverzicht is gebleken dat, vanuit de economisch-psychologische benadering, bij de verklaring van ware merktrouw, de voorkeur wordt gegeven aan een deterministische benadering op micro niveau met gebruik van gecombineerde maten. Een dergelijke benadering van ware merktrouw sluit goed aan bij de subjectieve (micro) indicatoren van tevredenheid, waaraan, zo blijkt uit het literatuuroverzicht, eveneens de voorkeur wordt gegeven.

Vanuit een economisch-psychologische benadering staat zowel bij de operationalisatie van ware merktrouw als bij de operationalisatie van tevredenheid, het individu centraal. Beide operationalisaties zijn, in ieder geval voor een deel, subjectief. De tevredenheid en de commitment van de consument worden niet objectief vastgesteld. Slechts het aankoopgedrag van de consument kan objectief worden vastgesteld.

Vanuit de deterministische benadering van ware merktrouw is het de bedoeling ware merktrouw te verklaren. Tevredenheid is een variabele die zal bijdragen aan de verklaring van ware merktrouw. Bij de verklaring van ware merktrouw spelen immers evaluatieprocessen een belangrijke rol en tevredenheid is gedefinieerd als de uitkomst van dat evaluatieproces.

Een deterministische benadering van tevredenheid is, gezien de doelstelling van dit onderzoek, niet noodzakelijk (omdat het niet de bedoeling is tevredenheid te verklaren). Het gevolg hiervan is dat volstaan kan worden met een beschrijvende benadering waarbij de uitkomst van het evaluatieproces centraal staat.

Diverse variabelen zijn, in de loop der tijd, in relatie tot merktrouw en tevredenheid onderzocht, zo is gebleken uit hoofdstuk 1 en hoofdstuk 2. In Schema 3.1 wordt een overzicht gegeven van de, bij ons bekende, relaties die in de literatuur beschreven worden. Met dit overzicht kan nagegaan worden of en $\mathrm{zo}$ ja, welke variabelen een bijdrage leveren aan de verklaring van beide concepten. 


\section{Persoonsgebonden variabelen}

\section{Psychologische produktvariabelen}

- commitment

- inertia

- involvement

- tevredenheid

- attitudes

- brand deliberation

- intenties

- evoked set

- perceptie verschillen

- gepercipieerd risico

- cognitieve dissonantie (reductie)

- verwachtingen over produkt

- produktprestatie

- confirmatie

- positieve disconfirmatie

- negatieve disconfirmatie

- ervaringen uit het verleden
Relatie met:

Merktrouw

positief

positief

positief

positief

positief

negatief

positief

negatief

positief

positief

positief

onbekend

onbekend

onbekend

onbekend

onbekend

onbekend
Tevredenheid

onbekend ${ }^{* *}$
onbekend
?*$^{*}$
onbekend
onbekend
onbekend
onbekend
onbekend
onbekend
onbekend
onbekend
positief
positief
positief
positief
negatief
$?$

geen\#

onbekend

onbekend

onbekend

onbekend

onbekend

onbekend

onbekend

onbekend

onbekend

onbekend

onbekend

\section{Aankoopvariabelen}

- tijd tussen twee aankopen

- tijd voor doen van aankopen

- aankoopfrequentie

- budgetaandeel merk

positief

onbekend

specifiek

specifiek

specifiek

onbekend

onbekend

\section{Marktvariabelen}

- introductie nieuwe merken

- concentratiegraad

- penetratiegraad

specifiek

onbekend

onbekend

negatief

positief

- prijs

- hedonistische prijs

onbekend

geen

onbekend

onbekend

? 


\section{Persoonsgebonden variabelen}

- promotie

- distributie

- distributiespreiding/prijs

- distributiespreiding/kwaliteit

- tijd dat merk op de markt is

- consumentenkosten

- transactiekosten

- heterogeen produkt/ heterogene markt

- bedrijf afhankelijk tevredenheid

Winkeltrouw/dealertrouw
Relatie met:

Merktrouw

?

positief

onbekend

onbekend

positief

onbekend

onbekend

onbekend

onbekend
Tevredenheid

onbekend

onbekend

negatief

positief

onbekend

negatief

negatief

positief

positief

positief

onbekend

*: onduidelijk verband tussen variabele en merktrouw of tevredenheid; \#: geen verband tussen variabele
en merktrouw of tevredenheid; **:verband tussen variabele en merktrouw of tevredenheid onbekend

Uit Schema 3.1 blijkt dat slechts van een beperkt aantal variabelen op grond van empirisch onderzoek bekend is of en in hoeverre zij een rol spelen bij de verklaring van zowel merktrouw als tevredenheid.

Een aantal persoons- en marktvariabelen die bijdragen aan de verklaring van merktrouw, dragen ook bij aan de verklaring van tevredenheid. Met name van een aantal marktvariabelen is gebleken dat zij, in het algemeen, bijdragen aan de verklaring van zowel merktrouw als tevredenheid. Wanneer de bijdrage van de specifieke marktvariabelen wordt vergeleken, blijkt bijvoorbeeld dat de concentratiegraad van de markt positief gerelateerd te zijn aan merktrouw, maar blijkt er geen verband te bestaan tussen concentratiegraad en tevredenheid. De relatie tussen merktrouw en prijs is nog onduidelijk, terwijl de relatie tussen tevredenheid en prijs niet is onderzocht.

Tevredenheid staat centraal in dit onderzoek bij de verklaring van ware merktrouw en niet de marktvariabelen. Gekozen is voor een partiële analyse vanuit een economischpsychologische invalshoek. In een later stadium kunnen variabelen en theorieën uit verschillende invalshoeken elkaar aanvullen. Daarom zal nu geen verdere aandacht aan de rol van de marktvariabelen worden besteed.

Van de persoonsvariabelen zijn de socio-economische-, demografische en persoonlijkheidsvariabelen niet of amper gerelateerd aan merktrouw en ook niet aan tevredenheid. Aankoopvariabelen en gebruiksvariabelen blijken van invloed te zijn op merktrouw; de relatie van aankoop- en gebruiksvariabelen met tevredenheid is vaak nog niet onderzocht. Wel kan worden aangenomen dat zowel tevredenheid als merktrouw situatieen/of domeinspecifiek zijn.

Voor één psychologische produktvariabele is de invloed op zowel merktrouw als tevredenheid geïnventariseerd. Dit is involvement. Involvement wordt verwacht positief gerelateerd te zijn aan ware merktrouw. De rol die involvement speelt bij tevredenheid is nog niet duidelijk. De kans op disconfirmatie neemt toe naarmate de involvement toeneemt. Daarnaast moet worden geconstateerd dat een merk bij hoge involvement uitgebreider geëvalueerd wordt dan bij lage involvement.

De overige psychologische variabelen zijn niet onderzocht bij de verklaring van zowel merktrouw als tevredenheid. Een vergelijking is daarom niet te maken. 
Merktrouw en tevredenheid worden bestudeerd vanuit een economisch-psychologisch perspectief. Overeenkomsten tussen merktrouw en tevredenheid betreffen de definiëring van beide concepten waarbij de psychologische antecedenten centraal staan, de procesbenadering (de uitkomst van), de operationalisatie en het feit dat beide door psychologische produkt- en marktvariabelen kunnen worden verklaard. Hoewel socio-economische en demografische variabelen niet bijdragen aan de verklaring van merktrouw of tevredenheid, wordt verwacht dat involvement een psychologische variabele is die zowel bijdraagt aan de verklaring van ware merktrouw (mede doordat involvement bijdraagt aan de verklaring van commitment) als tevredenheid.

Tot slot van deze paragraaf moet opgemerkt worden dat (mede door Schema 3.1) de indruk kan zijn ontstaan dat tevredenheid en ware merktrouw twee zijden van de zelfde medaille zijn en niet duidelijk van elkaar zijn te onderscheiden. Dit omdat identieke variabelen zouden bijdragen aan de verklaring van zowel tevredenheid als ware merktrouw. Dit wijzen wij nadrukkelijk van de hand. In onze visie is tevredenheid een variabele die bijdraagt aan de verklaring van ware merktrouw. Bovendien blijkt duidelijk (ook uit Schema 3.1) dat variabelen die bijdragen aan de verklaring van tevredenheid in de meeste gevallen niet bijdragen aan de verklaring van ware merktrouw en zo dit al het geval is, is de manier waarop een variabele bijdraagt en de theorie daaromtrent, verschillend.

\subsection{Kanttekeningen bij merktrouw}

\subsubsection{Definitie van ware merktrouw en een definitie van herhalingsaankopen}

Het is niet eenvoudig een goede definitie van merktrouw te geven. In de loop van de tijd zijn veel verschillende definities gepresenteerd. Deze definities zijn voor een klein deel conceptuele definities en voor het overgrote deel operationele definities.

De bekendste conceptuele definitie van merktrouw is de, ook door ons tot nu gebruikte, definitie van Jacoby en Chesnut (1978).

Een aantal, uit de literatuur afkomstige, met name positieve kanttekeningen bij deze definitie, zijn reeds in het literatuuroverzicht vermeld. Deze kanttekeningen betreffen met name de implicaties van de definitie. Een meer fundamentele kanttekening bij de definitie van Jacoby en Olson is hier op zijn plaats.

Zowel vanuit de literatuur als vanuit de praktijk wordt steeds vaker benadrukt dat het noodzakelijk is een duidelijk onderscheid te maken tussen ware merktrouw en herhalingsaankopen. Bij ware merktrouw is commitment een essentiële voorwaarde; bij herhalingsaankopen is dit niet het geval.

De definitie van Jacoby en Chesnut, biedt ons inziens echter nog onvoldoende gelegenheid een duidelijk onderscheid te maken tussen ware merktrouw en herhalingsaankopen omdat het meest essentiële aspect van het onderscheid niet voldoende wordt benadrukt. De aan- of afwezigheid van commitment bepaalt of 'the biased (i.e. nonrandom), behavioral response (i.e. purchase), expressed over time, by some decision making unit, with respect to one or more alternative brands out of a set of such brands, and is a function 
of psychological (decision making, evaluative) processes' een herhalingsaankoop of ware merktrouw is. In uitersten redenerend geldt het volgende: is de aankoop gebaseerd op commitment dan is er sprake van ware merktrouw, is de aankoop niet gebaseerd op commitment maar op inertia, dan is er sprake van herhalingsaankopen.

Hoewel het feitelijk gedrag hetzelfde is (hetzelfde merk opnieuw kopen), liggen verschillende psychologische processen aan het gedrag ten grondslag. Dit maakt dat het hetzelfde gedrag een verschillende betekenis heeft voor de consument en dus ook een verschillende betekenis moet hebben voor de aanbieder. Bij ware merktrouw hecht de consument aan de merkkeuze, de consument stelt het op prijs weer hetzelfde merk te kopen en vindt het dus belangrijk om aan de merkkeuze vast te houden. Voor de aanbieder betekent dit dat een ware merktrouwe consument niet gemakkelijk van merk zal wisselen, in ieder geval veel minder makkelijk dan een consument die het niet belangrijk vindt om vast te houden aan de merkkeuze.

Om ware merktrouw nauwkeurig te definiëren (en het daardoor beter af te bakenen van herhalingsaankopen) willen wij de definitie van Jacoby en Chesnut enigszins aanvullen. Ware merktrouw wordt door ons echter, net als door Jacoby en Chesnut (1978), gedefinieerd als:

The biased (i.e. nonrandom), behavioral response (i.e. purchase), expressed over time, by some decision making unit, with respect to one or more alternative brands out of a set of such brands, and is a function of psychological (decision making, evaluative) processes.

Maar veel nadrukkelijker dan Jacoby en Chesnut, willen wij er op wijzen dat als gevolg van de het expliciet doorlopen van de psychologische (beslissings- en evaluatie-) processen commitment bij het betreffende merk ontstaat (indien een merk positief wordt geevalueerd.) Dit betekent dat de consument nadrukkelijk wil vasthouden aan de merkkeuze. Wordt het merk bij een volgende aankoop inderdaad opnieuw gekocht op basis van de ontstane commitment, dan is er sprake van ware merktrouw.

Commitment is een noodzakelijke voorwaarde voor ware merktrouw; zonder commitment is er geen ware merktrouw. Is er geen commitment en wordt een merk bij een volgende aankoop opnieuw gekocht dan is er sprake van herhalingsaankopen. Deze herhalingsaankopen worden door ons gedefinieerd als:

The biased (i.e. nonrandom), behavioral response (i.e. purchase), expressed over time, by some decision making unit, with respect to one or more alternative brands out of a set of such brands and is a function of inertia.

Voor het ontstaan van commitment en dus voor ware merktrouw, is het noodzakelijk dat psychologische beslissings- en evaluatieprocessen expliciet worden doorlopen. In onze opvatting is het doorlopen van deze processen voor het doen van herhalingsaankopen, niet noodzakelijk. Herhalingsaankopen zijn volgens ons een functie van inertia; de consument koopt het merk, waarmee hij/zij het meest vertrouwd is of dat het gemakkelijkst te verkrijgen is, zonder er uitgebreid over na te denken. Door de toepassing van 
zeer simpele keuzeregels of heuristieken worden expliciete beslissings- en evaluatieprocessen omzeild. (Nogmaals willen wij er hierop wijzen dat de betekenis die wij hier geven aan inertia afwijkt van de betekenis die er in ander vakgebieden aan wordt gegeven. Inertia worden door ons opgevat als simpele keuzeheuristieken.)

Door het toevoegen van 'commitment' als noodzakelijke voorwaarde bij de definitie van ware merktrouw wordt het begrip vollediger en nauwkeuriger. Er kan hierdoor een duidelijk onderscheid worden gemaakt tussen ware merktrouw en herhalingsaankopen. Bovendien kan de mate van ware merktrouw - gebaseerd op de mate van commitment en het aankoopgedrag - worden vastgesteld.

\subsubsection{Continuüm voor herhalingsaankopen en ware merktrouw}

Op basis van onze definities van ware merktrouw en herhalingsaankopen kan een continuüm worden geconstrueerd waarbij ware merktrouw op het ene uiteinde wordt geplaatst en herhalingsaankopen op het andere uiteinde. Voor de beide uiteinden geldt dat er sprake is van "a biased (i.e. nonrandom) behavioral response, expressed over time, by some decisionmaking unit, with respect to one or more alternative brands out of a set of such brands". Worden psychologische evaluatie- en beslissingsprocessen niet expliciet doorlopen en is het gedrag een functie van inertia, dan is er sprake van herhalingsaankopen. Worden deze psychologische evaluatie- en beslissingsprocessen wel expliciet doorlopen en ontstaat daaruit commitment bij het merk, dan is er sprake van ware merktrouw. De mate van commitment kan variëren; het gaat niet om een 'alles of niets' situatie. Hierdoor kan een gradueel onderscheid worden aangebracht in de mate van merktrouw gebaseerd op de mate van commitment en het aankoopgedrag, zoals Figuur 3.1 laat zien.

Figuur 3.1: Het continuüm van herhalingsaankopen tot ware merktrouw

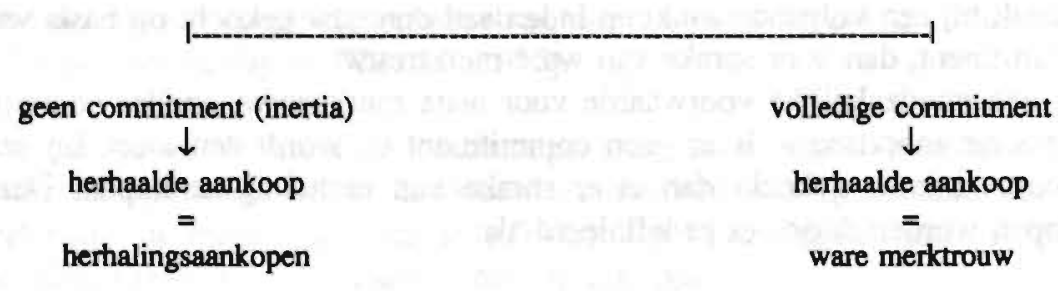

Ware merktrouw wordt door ons niet op én continuüm met ware merkontrouw geplaatst (net zo min als tevredenheid en ontevredenheid door Herzberg et al. (1959), ons inziens terecht, op één continuüm worden geplaatst). Dit betekent dat ware ontrouw (variety seeking of het bewust een ander merk kopen), volgens ons niet in het verlengde ligt van ware trouw. Wij prefereren een continuüm van meer versus minder ware merktrouw boven een continuüm van ontrouw versus trouw. Op het eerste continuüm is het feitelijke gedrag identiek (het herhaald kopen van een merk); op het tweede continuüm zijn twee verschillende feitelijke gedragingen vertegenwoordigd (het herhaald kopen van een merk en het niet herhaald kopen van een merk). Bovendien zijn de antecedenten en 
consequenties van trouw en ontrouw zodanig fundamenteel verschillend dat beide begrippen onmogelijk op één continuüm kunnen worden geplaatst. En daamaast geldt dat het afnemen van trouw niet persé in ontrouw overgaat. Wanneer de commitment van de consument geheel is afgenomen kan het merk nog steeds herhaald gekocht worden op basis van inertia.

Het tegenovergestelde van ware merktrouw is in onze opvatting en in aansluiting bij de opvattingen van Herzberg et al. (1959) geen ware merktrouw dus herhalingsaankopen en niet ware merkontrouw.

\subsubsection{Commitment}

Commitment is het cruciale concept in onze definitie van ware merktrouw; zonder commitment, geen ware merktrouw. Commitment is dus een noodzakelijke voorwaarde voor ware merktrouw. De mate van commitment kan variëren en wordt door ons gedefinieerd als:

De mate waarin een subject nadrukkelijk wil vasthouden aan de merkkeuze in een niet nader omschreven, toekomstige koopsituatie.

Onze definitie van commitment is gebaseerd op de definitie van Lastovicka en Gardner (1978). Door het expliciet doorlopen van evaluatie- en beslissingsprocessen is de consument er van overtuigd dat hij/zij nadrukkelijk wil vasthouden aan de merkkeuze in een niet nader omschreven, toekomstige koopsituatie. De mate of de sterkte van de commitment wordt bepaald door de mate waarin de consument nadrukkelijk wil vasthouden aan de merkkeuze. Het willen vasthouden aan de merkkeuze betekent dat de consument een binding heeft met het merk. Deze binding zorgt er voor dat consumenten bijvoorbeeld niet snel van merk wisselen wanneer het eigen merk in prijs wordt verhoogd of andere merken in prijs worden verlaagd (lage kruislingse prijselasticiteit).

Bij de operationalisatie van ware merktrouw moet er voor gewaakt worden dat niet alleen op gedragsniveau wordt gemeten (dus in termen van het al dan niet kopen van een merk), maar dat ook de commitment ten aanzien van het merk wordt gemeten (als noodzakelijke voorwaarde). Het meest voor de hand liggend, om ware merktrouw te meten, zijn de in hoofdstuk 1 besproken gecombineerde - of daarmee vergelijkbare maten.

In het hoofdstuk $1 \mathrm{komt}$ tevens naar voren dat merktrouw wordt gemeten met behulp van gedragsvariabelen en psychologische variabelen. Het is opvallend dat, tot nu toe, slechts een enkele keer de psychologische maat van ware merktrouw is geoperationaliseerd in termen van commitment (Cunningham, 1967; zie paragraaf 1.3.2 waar Cunningham de term 'stated brand commitment' hanteert).

Verschillende operationalisaties van de resultante van de doorlopen evaluatie- en beslissingsprocessen (bijvoorbeeld attitude, intentie, preferentie) wekken de indruk alsof verschillende andere psychologische concepten in plaats van commitment kunnen worden gebruikt om te bepalen of er sprake is van ware merktrouw. Ons inziens is het alleen commitment dat bepaalt of er sprake is van ware merktrouw of niet. Commitment 
is immers een noodzakelijke voorwaarde voor ware merktrouw; een positieve attitude, intentie of preferentie kan samenhangen met ware merktrouw, maar is (zijn) geen noodzakelijke en ook geen voldoende voorwaarde(n).

De manieren waarop ware merktrouw in het verleden is geoperationaliseerd geven aanleiding te veronderstellen dat commitment in die tijd is verward met concepten als attitude, intentie of preferentie. Daamaast kan het zo zijn dat men, ons inziens onterecht, werkelijk heeft gemeend het psychologische aspect van ware merktrouw in termen van attitude, intentie of preferentie te kunnen operationaliseren of dat men in ieder geval uitging van de gedachte dat een positieve attitude, intentie of preferentie een noodzakelijke voorwaarde vormde voor ware merktrouw.

Een positieve attitude is, volgens ons, een onvoldoende voorwaarde voor ware merktrouw. Attitude wordt door ons gedefinieerd als een houding ten opzichte van een stimulus (merk). Een positieve attitude ten opzichte van een merk betekent nog niet dat het merk wordt verkozen boven andere merken.

Een intentie wordt door ons gedefinieerd als het voornemen om een bepaald gedrag te vertonen in een bepaalde situatie (een bepaald merk te kopen). De intentie om een bepaald merk te kopen, is een onvoldoende voorwaarde voor ware merktrouw, met name omdat onduidelijk is in hoeverre de consument bereid is vast te houden aan deze intentie.

De preferentie van consumenten voor een bepaald merk betekent niet dat consumenten zonder meer serieus aan deze preferentie willen en kunnen vasthouden. Preferentie wordt door ons opgevat als de voorkeur voor een bepaald merk. Deze voorkeur betekent nog geenszins dat het merk feitelijk zal worden verkozen boven andere merken.

Commitment geeft daarentegen aan in hoeverre een consument nadrukkelijk aan zijn/haar merkkeuze wil vasthouden in een niet nader omschreven, toekomstige koopsituatie.

Gezien het cruciale belang van commitment bij de verklaring van ware merktrouw, zal in hoofdstuk 4 een kort overzicht van de literatuur over commitment worden gegeven. Hierbij zal nadere aandacht worden besteed aan de conceptualisatie en operationalisatie van commitment.

In het literatuuroverzicht is melding gemaakt van het feit dat meerdere malen een duidelijk positief verband tussen involvement en commitment is geconstateerd. Wanneer er vanuit wordt gegaan dat commitment een noodzakelijke voorwaarde is voor ware merktrouw, betekent dit dat involvement wellicht een variabele is die eveneens bijdraagt aan de verklaring van ware merktrouw. Echter, de rol van involvement bij de verklaring van ware merktrouw is, ons inziens, gecompliceerder dan op het eerste gezicht, naar aanleiding van de positieve relatie tussen involvement en commitment, verwacht zou kunnen worden. (Het conceptuele verschil tussen involvement en commitment komt in hoofdstuk 4 nader aan de orde.) 
In het literatuuroverzicht is tevredenheid door ons gedefinieerd als de uitkomst van een evaluatief proces. Hoewel niet alle literatuur bij deze opvatting over tevredenheid aansluit, wordt er in alle onderzoeken wel (impliciet) vanuit gegaan dat elke consument, in iedere situatie, elk produkt (of merk) evalueert en een tevredenheidsoordeel heeft. Echter is het de vraag hoe manifest dit oordeel is. Een manifest tevredenheidsoordeel is in onze opvatting een tevredenheidsoordeel dat gebaseerd is op het uitgebreid doorlopen van het evaluatieproces van het produkt (of merk). Het is echter zeer de vraag of iedere consument, een produkt uitgebreid evalueert en uiteindelijk tot een manifest tevredenheidsoordeel over het produkt zal komen (Bloemer en Poiesz, 1989).

Voor een manifest tevredenheidsoordeel is het in de eerste plaats noodzakelijk dat de consument verwachtingen over de produktprestatie heeft en bereid en in staat is om de produktprestatie te beoordelen. Vervolgens moet een vergelijking worden gemaakt tussen de verwachtingen over de produktprestatie en de feitelijke produktprestatie. Hierbij is het van belang dat consumenten nadrukkelijk een verschil tussen de verwachte produktprestatie en de feitelijke produktprestatie waamemen. Het is ook denkbaar dat het verschil tussen verwachte produktprestatie en feitelijke produktprestatie in de ogen van de consument klein is, waardoor het gemakkelijk kan worden geassimileerd. Daarnaast is het noodzakelijk dat wanneer het verschil tussen verwachte produktprestatie en feitelijke produktprestatie niet wordt geassimileerd, dit verschil niet wordt gezien als een normale, te verwachten en acceptabele afwijking. Tot slot is het noodzakelijk dat de consument de positieve afwijking tussen produktprestatie en verwachting niet afdoet als onbelangrijk door bijvoorbeeld te stellen 'ik heb geluk gehad'. Wanneer de consument geen verwachtingen over de produktprestatie heeft gevormd - wanneer de produktprestatie moeilijk te beoordelen is, wanneer geen duidelijk verschil wordt waargenomen tussen de prestatie van het produkt en de verwachting ten aanzien van die prestatie, wanneer het verschil tussen beide gemakkelijk wordt geassimileerd of wanneer het verschil tussen beide als betekenisloos wordt afgedaan - ontstaat hoogstens impliciete acceptatie van een merk, zeker geen manifest tevredenheidsoordeel.

Om beter inzicht te krijgen in de uitgebreidheid waarmee evaluatieprocessen worden doorlopen, kan gebruik worden gemaakt van de kennis over 'elaboration likelihood', gepresenteerd door Petty, Cacioppo en Schumann (1983).

De uitgebreidheid waarmee een evaluatieproces wordt doorlopen kan volgens Petty, Cacioppo en Schumann worden uitgedrukt in de mate van elaboratie. Deze mate van elaboratie is afhankelijk van de motivatie en de capaciteit van de consument. Indien de capaciteit en de motivatie van de consument voldoende groot zijn, neemt de consument de centrale route. Deze route leidt, in termen van het Elaboration Likelihood Model, tot een permanente attitudeverandering (zie tevens paragraaf 4.5 ). Is de consument niet gemotiveerd en/of beschikt de consument niet over de capaciteit om het produkt te evalueren, dan neemt de consument de perifere route. Deze route leidt hoogstens tot een tijdelijke attitudeverandering.

In het kader van dit onderzoek betekent dit, dat consumenten die over voldoende motivatie en capaciteit beschikken, het merk uitgebreid zullen evalueren en dientengevolge 
een manifest tevredenheidsoordeel hebben. Consumenten die niet beschikken over voldoende motivatie en/of capaciteit zullen het merk niet uitgebreid evalueren en geen manifest tevredenheidsoordeel, maar een latent tevredenheidsoordeel hebben. Dit latente tevredenheidsoordeel houdt niet meer in dan de impliciete acceptatie van het merk.

Het tevredenheidsoordeel dat, in termen van het Elaboration Likelihood Model of ELM, via de centrale route ontstaat, is dus een ander tevredenheidsoordeel dan het tevredenheidsoordeel dat via de perifere route ontstaat. Er moet volgens ons daarom een onderscheid worden gemaakt tussen twee soorten tevredenheid: manifeste tevredenheid en latente tevredenheid.

In het ELM (Petty, Cacioppo en Schumann, 1983) wordt aangegeven dat een attitudeverandering die via de centrale route tot stand komt, permanent is, terwijl een attitude verandering die tot stand komt via de perifere route, tijdelijk is. Een permanente attitudeverandering, ceteris paribus, leidt tot een meer permanente verandering in gedrag dan een tijdelijke attitudeverandering, welke hooguit zal leiden tot een tijdelijke verandering in gedrag.

Analoog hieraan zal manifeste tevredenheid (vergelijkbaar met de permanente attitudeverandering in het ELM, ontstaan via de centrale route), leiden tot ware merktrouw terwijl latente tevredenheid (vergelijkbaar met een tijdelijke attitudeverandering in het ELM, ontstaan via de perifere route) hoogstens aanleiding geeft tot herhalingsaankopen. Met andere woorden, manifeste tevredenheid wordt door de consument eenduidig tot uitdrukking gebracht in doelbewust gedrag (ware merktrouw, vaker of meer kopen van het merk, positieve mond tot mond reclame, merk aanbevelen aan anderen, etc.), omdat de consument het merk uitgebreid heeft geëvalueerd en op basis van deze evaluatie tot een manifest tevredenheidsoordeel is gekomen.

Latente tevredenheid zal door de consument niet eenduidig tot uitdrukking worden gebracht omdat de consument het merk slechts impliciet accepteert; de consument zal niet op een duidelijke eenduidige manier uitdrukking kunnen geven aan dit oordeel (eventueel wordt een herhalingsaankoop gedaan maar er kan ook een ander merk worden gekocht).

Tot nu toe zijn door ons twee soorten tevredenheid onderscheiden. Manifeste tevredenheid en latente tevredenheid (of impliciete acceptatie). Manifeste tevredenheid ontstaat alleen indien de consument over voldoende motivatie en capaciteit beschikt om een merk te evalueren. Beschikt de consument niet over voldoende motivatie en/of capaciteit dan ontstaat latente tevredenheid. Deze is laatste slechts gebaseerd op de omgang met het merk en houdt niet meer in dan een impliciete acceptatie van het merk.

De rol van tevredenheid bij de verklaring van ware merktrouw is afhankelijk van de soort tevredenheid. Manifeste tevredenheid draagt volgens ons bij aan de verklaring van ware merktrouw. Impliciete acceptatie draagt volgens ons niet bij aan de verklaring van ware merktrouw.

In termen van het ELM-model kan de motivatie van de consument om een merk te evalueren worden geoperationaliseerd met behulp van de involvement bij de merkkeuze 
(Cacioppo en Petty, 1982). Deliberatie over de merkkeuze kan volgens ons als een operationalisatie van de capaciteit van de consument om de merkkeuze te evalueren worden beschouwd. De soort tevredenheid kan worden vastgesteld op basis van de involvement bij de merkkeuze en de deliberatie over de merkkeuze. Deliberatie over de merkkeuze wordt door ons gedefinieerd als het (kunnen) nadenken over de merkkeuze. Hiervoor moet de consument over de capaciteit en de gelegenheid beschikken om over de merkkeuze na te denken (vergelijk Poiesz, 1989).

Onze visie dat verschillende soorten tevredenheid van elkaar kunnen worden onderscheiden afhankelijk van de mate van elaboratie, in termen van manifeste tevredenheid en impliciete acceptatie, wordt ook vanuit andere visies in de literatuur ondersteund.

Freedman (1964) en Jacoby (1971) wijzen reeds op het feit dat involvement de grootte van de 'zone of acceptance' beïnvloedt en daardoor het tevredenheidsoordeel. Day (1977) stelt dat consumenten geen evaluaties maken van eenvoudige produkten. Swan en Trawick (1979) stellen vast dat de mate van produktevaluatie afhangt van de produktklasse, waarbij elke produktklasse, volgens hen, een verschillend niveau van betrokkenheid vertegenwoordigt. Engel, Blackwell en Miniard (1986, p. 157) stellen dat "... satisfaction builds on a conscious and deliberate evaluation of outcomes. As would be expected, the strength of reaction is much greater when there is a high degree of involvement".

Omdat het noodzakelijk wordt geacht twee verschillende soorten tevredenheid te onderscheiden die afhankelijk zijn van de mate van elaboratie over de merkkeuze van een consument en waarbij involvement en deliberatie als indicatoren van de mate van elaboratie worden beschouwd, wordt in hoofdstuk 4 nader aandacht aan involvement en deliberatie geschonken.

\subsection{Merktrouw en tevredenheid: het definitieve model (Model I)}

In deze paragraaf zal onze eigen alternatieve benadering voor de verklaring van ware merktrouw en de rol van tevredenheid daarbij, worden weergegeven. Vervolgens zal een model worden gepresenteerd waarin de relaties tussen de variabelen het beste tot uitdrukking kunnen worden gebracht en zullen onderzoekshypothesen worden geformuleerd. Aan het einde van deze paragraaf wordt aandacht besteed aan enkele recente studies naar de relatie tussen merktrouw en tevredenheid zoals deze in de literatuur aanwezig zijn. Nagegaan wordt dan in hoeverre die studies aansluiten bij onze benadering.

\subsubsection{Alternatieve visie op de rol van tevredenheid bij de verklaring van ware merktrouw}

Vanaf de inleiding van dit boek is het onderscheid tussen herhalingsaankopen en ware merktrouw benadrukt. Nogmaals willen wij hier stellen dat het onze doelstelling is ware merktrouw te verklaren. Alleen ware merktrouw is gebaseerd op commitment bij het merk. Deze commitment bij het merk betekent dat de consument nadrukkelijk wil vast- 
houden aan zijn/haar merkkeuze en dus niet makkelijk op een ander merk zal overstappen. Commitment is een noodzakelijke voorwaarde voor ware merktrouw.

Uit de probleemstelling van dit onderzoek wordt duidelijk dat met name de rol van tevredenheid bij de verklaring van ware merktrouw zal worden onderzocht. Door ons is in paragraaf 3.3 aangegeven dat een onderscheid moet worden gemaakt tussen verschillende soorten tevredenheid: manifeste tevredenheid en latente tevredenheid of impliciete acceptatie. Manifeste tevredenheid ontstaat doordat de consument een merk uitgebreid evalueert en een duidelijk, expliciet tevredenheidsoordeel vormt. Dit tevredenheidsoordeel zal eenduidig van invloed zijn op de omgang met het merk in de toekomst. Latente tevredenheid is daarentegen niet meer dan impliciete acceptatie die niet op een uitgebreide evaluatie van het merk is gebaseerd. Latente tevredenheid zal minder duidelijk dan manifeste tevredenheid van invloed zijn op de omgang met het merk in de toekomst. Het onderscheid tussen manifeste en latente tevredenheid is afhankelijk van de motivatie en de capaciteit van de consument om de merkkeuze te evalueren.

Manifeste tevredenheid zal vanuit onze visie indirect, via commitment, in positieve zin bijdragen aan de verklaring van ware merktrouw. Gegeven dat commitment een noodzakelijke voorwaarde is voor ware merktrouw zullen commitment en ware merktrouw direct en positief met elkaar samenhangen. Manifeste tevredenheid is een resultante van het uitgebreid doorlopen van een evaluatieproces. Naarmate de manifeste tevredenheid toeneemt zal de commitment bij het merk toenemen. Daarom zal manifeste tevredenheid direct positief bijdragen aan de verklaring van commitment (en indirect positief aan de verklaring van ware merktrouw).

Latente tevredenheid daarentegen, zal niet bijdragen aan de verklaring van ware merktrouw, hooguit aan de verklaring van herhalingsaankopen. Omdat zich op grond van latente tevredenheid geen commitment bij het merk zal ontwikkelen. Een toename van de latente tevredenheid zal niet leiden tot een toename van de commitment bij het merk (en tot ware merktrouw).

Of tevredenheid bijdraagt aan de verklaring van ware merktrouw is dus afhankelijk van de soort tevredenheid. Deze is afhankelijk van de motivatie en de capaciteit van de consument om de merkkeuze te evalueren. Als indicator voor de motivatie kan gebruik worden gemaakt van involvement bij de merkkeuze en als indicator voor de capaciteit kan gebruik worden gemaakt van deliberatie. (Meer hierover in hoofdstuk 4.)

Door ons zijn een aantal nuanceringen aangebracht in de bestaande theorie omtrent de relatie tussen merktrouw en tevredenheid. In de bestaande theorie wordt immers een directe relatie tussen tevredenheid en merktrouw verondersteld waarbij geen rekening wordt gehouden met verschillende soorten merktrouw en verschillende soorten tevredenheid. Wij hebben het op de eerste plaats noodzakelijk geacht een onderscheid te maken tussen ware merktrouw en herhalingsaankopen en op de tweede plaats een onderscheid te maken tussen manifeste en latente tevredenheid. Hierdoor is het volgens ons mogelijk een betere verklaring, dan de tot nu toe bestaande verklaringen, te geven voor ware merktrouw en de rol van tevredenheid daarbij. Wij verwachten dat commitment een directe positieve bijdrage levert aan de verklaring van ware merktrouw en dat manifeste tevredenheid, via commitment, een indirecte positieve bijdrage levert aan de verklaring 
van tevredenheid. Latente tevredenheid zal niet bijdragen aan de verklaring van ware merktrouw, hooguit aan de verklaring van herhalingsaankopen.

\subsubsection{Model voor de verklaring van ware merktrouw}

In het voorgaande is uitgebreid aan de orde gekomen welke variabelen naar onze mening van belang zijn om de relatie tussen ware merktrouw en tevredenheid op een adequate wijze te onderzoeken. Het is hierbij onvoldoende om alleen naar het verband tussen tevredenheid en merktrouw te kijken. Wij hebben apart aandacht besteed aan de invloed van commitment (onderscheiden naar de mate van commitment) waardoor het mogelijk is een onderscheid aan te brengen tussen ware merktrouw en herhaald aankoopgedrag. Eveneens is de factor elaboratie geïntroduceerd (geoperationaliseerd in termen van involvement en deliberatie) waardoor het mogelijk is een onderscheid aan te brengen tussen manifeste en latente tevredenheid.

In het algemeen gezegd zouden wij de relatie tussen merktrouw en tevredenheid als volgt willen weergeven (Figuur 3.2a):

Figuur 3.2a: Algemeen Model I van de relatie tussen merktrouw en tevredenheid

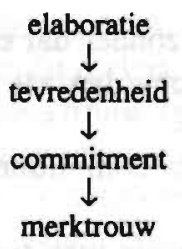

Figuur 3.2a wordt vervolgens nader worden gespecificeerd voor ware merktrouw (Figuur 3.1b) en voor herhalingsaankopen (Figuur 3.1c).

Figuur 3.2b: Model I van de relatie tussen ware merktrouw en manifeste tevredenheid

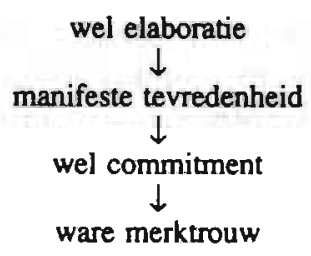

Figuur 3.2c: Model I van de relatie tussen herhalingsaankopen en latente tevredenheid

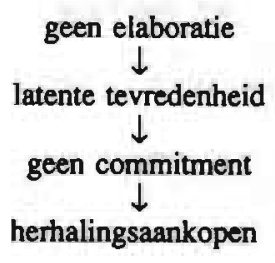


Figuur 3.2 (a t/m c) kan als volgt worden toegelicht:

De directe positieve relatie tussen commitment en ware merktrouw vloeit voort uit het feit dat commitment een noodzakelijke voorwaarde is voor ware merktrouw. Ware merktrouw is gebaseerd op commitment en naarmate de commitment toeneemt, neemt de ware merktrouw toe.

Manifeste tevredenheid is direct positief van invloed op commitment; naarmate de manifeste tevredenheid toeneemt, stijgt de commitment. Daarnaast is manifeste tevredenheid indirect via commitment van invloed op ware merktrouw.

Latente tevredenheid is niet gerelateerd aan commitment. Naarmate de latente tevredenheid stijgt, nemen de herhalingsaankopen mogelijk toe.

Uitgangspunt voor het model en onze studie is uiteraard een positieve evaluatie merk. Figuur $3.2 \mathrm{~b}$ betreffende de relatie tussen ware merktrouw en manifeste tevredenheid staat in het vervolg van dit onderzoek het meest centraal.

\section{5}

\section{Hypothesen}

Aan Figuur 3.2b dat een beschrijving geeft van de relatie tussen manifeste tevredenheid en ware merktrouw liggen de volgende hypothesen ten grondslag:

1 Tussen de mate van tevredenheid (zonder dat een onderscheid wordt gemaakt tussen manifest en latent) en ware merktrouw bestaat geen directe relatie.

2 Tussen de mate van tevredenheid en commitment bestaat wel een directe relatie.

3 Tussen manifeste tevredenheid en ware merktrouw bestaat geen directe relatie.

4 Manifeste tevredenheid leidt tot commitment.

5 Deze commitment leidt uiteindelijk tot ware merktrouw.

Bij deze hypothesen wordt de volgende assumptie gehanteerd:

Naarmate de mate van elaboratie toeneemt (dat wil zeggen naarmate involvement en deliberatie groter zijn), is de tevredenheid meer manifest.

Schematisch kunnen de hypothesen als volgt worden weergegeven (Figuur 3.3):

Figuur 3.3: Schematische weergave hypothesen

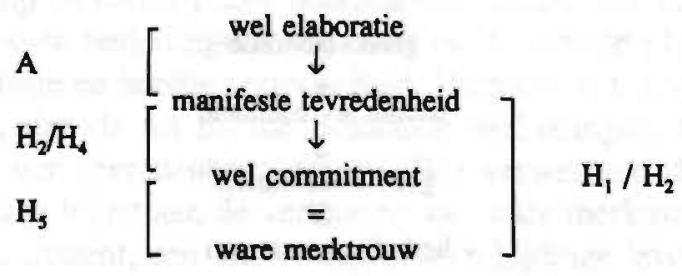

$\mathrm{H}$ : hypothese; $\mathrm{A}$ : assumptie. 
Voor een aantal recente onderzoeken zal hieronder worden aangegeven hoe de relatie tussen merktrouw en tevredenheid is onderzocht en hoe de manier van onderzoek mogelijk van invloed is geweest op de resultaten. Tevens wordt nagegaan in hoeverre deze onderzoeken aansluiten bij het door ons gepresenteerde onderzoeksmodel.

Newman en Werbel (1973) maken in hun studie naar de relatie tussen merktrouw en tevredenheid gebruik van huishoudelijke apparatuur: koelkast, wasmachine, fornuis, televisie en air conditioning. Dit zijn produkten waarbij in het algemeen een hoge involvement bij de merkkeuze kan worden verondersteld. Er kan daarom vanuit worden gegaan dat manifeste tevredenheid met deze produkten is gemeten (bij een hogere involvement is een consument eerder geneigd een merk uitgebreid te evalueren). Merktrouw is gemeten in termen van zowel feitelijke herhalingsaankopen als in termen van 'brand deliberation'. Er is getracht merktrouw hierdoor meer inhoud te geven. Deze studie komt op deze wijze het dichtst in de buurt van het meten van manifeste tevredenheid en ware merktrouw. Er wordt een positief verband tussen 'manifeste' tevredenheid met het oude merk en 'ware merktrouw' gerapporteerd.

LaBarbera en Mazursky (1983) onderzoeken de relatie tussen (on)tevredenheid en de intentie tot een herhalingsaankoop. Uit dit onderzoek blijkt dat tevredenheid in positieve zin bijdraagt aan de verklaring van merktrouw (geoperationaliseerd als intentie tot een herhalingsaankoop). De produkten die worden onderzocht zijn margarine, koffie, toiletpapier, papieren servetten en macaroni. Dit zijn produkten met in het algemeen een lage involvement bij de merkkeuze. Dit betekent waarschijnlijk dat in dit onderzoek geen manifeste tevredenheid is gemeten. Daarnaast is geen ware merktrouw, maar slechts de intentie tot een herhalingsaankoop gemeten.

Garfein (1987) maakt melding van een case-study waarin de relatie tussen tevredenheid met de service van een creditcard maatschappij en het gebruik van de kaart wordt nagegaan. Tevreden consumenten gaan vaker gebruik van de kaart maken. Ontevreden consumenten gaan minder gebruik maken van de kaart. In dit onderzoek is herhalingsaankoopgedrag gemeten. De commitment met betrekking tot de creditcard is niet onderzocht. Onduidelijk is verder of het gaat om manifeste of latente tevredenheid.

Kasper (1988) maakt in zijn studie gebruik van kleurentelevisies. Eén van de conclusies van zijn onderzoek luidt dat op basis van tevredenheid met het merk niet gediscrimineerd kan worden tussen merktrouwe en niet merktrouwe consumenten. Tevredenheid wordt in de studie gemeten als het aan- of afwezig zijn van problemen met het produkt. Merktrouw wordt gemeten in termen van intenties tot een herhalingsaankoop en feitelijk gedrag.

Bloemer, Kasper en Lemmink (1990) en Bloemer en Lemmink (1991) rapporteren een positieve relatie tussen de tevredenheid met de auto en tevredenheid met de after-sales 
service en merktrouw enerzijds en tevredenheid met de after-sales service en tevredenheid met de sales service en dealertrouw anderzijds. Dealertrouw vervult een intermedierende functie in de relatie tussen tevredenheid en merktrouw.

Als wordt aangenomen dat in het algemeen de involvement bij de merkkeuze van auto's groot is, is manifeste tevredenheid gemeten. Trouw aan het merk of aan de dealer is echter gemeten in termen van intenties. Aan commitment met betrekking tot het merk is in deze studie helaas geen aandacht besteed.

Burmann (1991) constateert dat de tevredenheid met de auto de beste voorspeller is van merktrouw. De tevredenheid met de after-sales service is indirect via de dealertrouw van invloed op merktrouw. Burmann gaat er in het theoretische gedeelte van zijn onderzoek van uit dat involvement zowel van invloed is op tevredenheid als op merktrouw. Involvement is echter niet opgenomen in het model waarmee uiteindelijk de relatie tussen tevredenheid en trouw wordt getoetst.

In de geringe hoeveelheid onderzoek naar de relatie tussen merktrouw en tevredenheid is voomamelijk herhaald ankoopgedrag gemeten. $\mathrm{Er}$ is gekeken naar het feitelijke aankoopgedrag van de consument of naar zijn/haar intentie tot dat aankoopgedrag. De commitment met betrekking tot het merk is meestal geheel buiten beschouwing gelaten. Naar verwachting is men er in de onderzoeken steeds vanuit gegaan dat de consument een manifest tevredenheidsoordeel geeft. De onderzoeken van Newman en Werbel (1973) en Bloemer, Kasper en Lemmink (1990) en Bloemer en Lemmink (1991) benaderen de relatie, zoals door ons beschreven, tussen manifeste tevredenheid en ware merktrouw het beste. 
Commitment, involvement en deliberatie zijn drie psychologische concepten die volgens ons bijdragen aan de verklaring van ware merktrouw en een beter inzicht kunnen geven in de rol van tevredenheid bij deze verklaring.

In het voorgaande hoofdstuk is nog onvoldoende aandacht aan de definiëring, de verantwoording en de afbakening van deze concepten besteed. Daarom wordt in dit hoofdstuk hierop nader ingegaan.

Allereerst wordt aandacht besteed aan de definiëring en verantwoording van de verschillende concepten. Het commitment concept zal nogmaals kort worden besproken. In de literatuur wordt weinig aandacht besteed aan dit concept; zeker als we ons beperken tot de literatuur die betrekking heeft op het consumentengedrag. Het involvement concept zal uitvoeriger worden besproken aangezien in de literatuur veel verschillende conceptualisaties en operationalisaties worden aangetroffen. De door ons gekozen benadering van het involvement concept zal met behulp van een literatuuroverzicht worden verantwoord. Tevens zal worden ingegaan op de afbakening van involvement en commitment ten opzichte van elkaar, omdat de twee concepten dicht tegen elkaar aanliggen.

Daarna zal het deliberatie concept slechts worden besproken; in de literatuur is weinig informatie over dit concept aanwezig. Tot slot wordt aandacht besteed aan het Elaboration Likelihood Model. Dit model staat aan de basis van onze opvattingen over de verklaring van ware merktrouw en de rol die tevredenheid daarbij speelt.

\subsection{Commitment}

\subsubsection{Conceptualisatie van commitment}

Enkele recente definities van commitment die worden aangetroffen in de marketing- en consumentengedragsliteratuur zijn:

Commitment is "the pledging or binding of an individual to his brand choice" (Kiesler, 1968 en Lastovicka en Gardner, 1977).

Commitment is "the human propensity to engage in consistent lines of activity - or role behaviors - over time" (Lee en Zeiss, 1980).

"Psychological commitment refers to a tendency to resist change in preference in response to conflicting information or experience. Psychological commitment is maximized when (1) the individual is motivated by a need to maintain consistent relationships between preference and salient aspects of cognitive structure, and (2) important values 
and self-images are linked to the preference, leading to a state of position involvement" (Crosby and Taylor, 1983).

"Commitment refers to an implicit or explicit pledge of relational continuity between exchange partners" (Dwyer, Shurr en Oh, 1987).

Commitment is "an emotional or psychological attachment to a brand within a product class" (Beatty et al., 1988).

Commitment is "a psychological bondor bound" (Hollenbeck et al., 1989 en Hunt et al., 1989).

"Commitment implies an intense, long-term loyalty and dedication demonstrated through continued patronage, even if we have a single bad experience" (Ulrich, 1989).

In onze eigen definitie van commitment betrekken wij meteen de mate van commitment omdat commitment in ons onderzoek een relatief begrip is. De mate van commitment definiëren wij als volgt:

De mate waarin een subject nadrukkelijk wil vasthouden aan de merkkeuze in een niet nader omschreven, toekomstige koopsituatie.

Deze definitie is gebaseerd op de definitie van Kiesler (1968) en Lastovicka en Gardner (1977). Zij sluit goed aan bij het geformuleerde onderzoeksmodel omdat duidelijk naar voren komt dat de consument wil vasthouden aan zijn/haar merkkeuze, zij het dat de koopsituatie waarin nog niet volledig is vastgelegd. (Wij willen er hier nogmaals op wijzen dat onze definiëring van commitment afwijkt van definiëring binnen andere vakgebieden, zoals bijvoorbeeld de industriële organisatie. Daar impliceert commitment 'onomkeerbaarheid' van een relatie. In ons onderzoek is dit niet het geval.)

\subsubsection{Operationalisatie van commitment}

Commitment wordt voomamelijk gemeten met behulp van Likert-schalen. In de literatuur kunnen bij Lastovicka en Gardner (1977), Beatty et al. (1988) en Mittal en Lee (1989) schalen worden gevonden waarmee de mate van commitment aan produkten kan worden gemeten. Hiervan is ook gebruik gemaakt bij de constructie van onze vragenlijsten (zie paragraaf 5.4).

\subsection{Involvement}

\subsubsection{Conceptualisatie van involvement}

Involvement wordt op verschillende manieren gedefinieerd. Wanneer naar de literatuur wordt gekeken blijkt dat vrijwel iedere auteur een eigen definitie hanteert. Dit bevordert geenszins de overzichtelijkheid. Toch is het van belang een aantal gehanteerde definities 
uit de meest belangrijke onderzoeken met betrekking tot involvement op een rij te zetten (Bijlage 2). Hieruit kunnen gemeenschappelijke kenmerken worden afgeleid en kan worden bepaald hoe involvement, in het kader van het onderzoek naar de verklaring van ware merktrouw, moet worden gedefinieerd.

Sherif en Cantril zijn in 1947 waarschijnlijk de eersten die de term involvement hebben gebruikt. Zij definiëren involvement als 'the state of an organism, when presented with any stimulus which is ego central, or when any stimulus is either consciously or subconsciously related to the ego'.

Rajaniemi en Laaksonen (1986) en Costley (1988) onderscheiden eind jaren tachtig, drie soorten definities: definities die uitgaan van een respons benadering; definities die uitgaan van een individuele toestandsbenadering en definities die uitgaan van een cognitieve benadering.

Wanneer wordt uitgegaan van een respons benadering wordt involvement beschouwd als een afhankelijke variabele. De complexiteit en uitgebreidheid van evaluatie- en beslissingsprocessen zijn bepalend voor de mate van involvement. Naarmate deze processen complexer en uitgebreider zijn neemt vanuit deze visie, de involvement toe (Krugman, 1965 en Houston en Rothschild, 1978).

Indien wordt uitgegaan van een individuele toestandsbenadering van involvement dan wordt involvement beschouwd als een onafhankelijke variabele. De involvement van de consument bij een object wordt beschouwd als een motiverende variabele (arousal, interest) die direct (zowel qua intensiteit als richting) van invloed is op evaluatie- en beslissingsprocessen (Mitchell, 1979; Hansen, 1981; Mittal, 1988; Bloch en Richins, 1983; Cohen, 1983; Antil, 1984; Rothschild, 1984; Park en Mittal, 1985 en Mittal en Lee, 1989).

De cognitieve benadering van involvement gaat er van uit dat involvement een interveniërende of moderator-variabele is. Involvement refereert aan het gepercipieerde persoonlijk belang van een object voor een individu (Traylor, 1981; Engel en Blackwell, 1982; Lastovicka en Bonfield, 1982; Hansen, 1985; Zaichowsky, 1985; Celsi en Olson, 1989 en Engel et al. 1990). Involvement bepaalt op de eerste plaats de intensiteit en niet de richting van evaluatie- en beslissingsprocessen. Dit wil zeggen dat het gaat om een predispositie om te reageren en niet om de specifieke manier van reageren.

Gezien onze onderzoeksdoelstelling en het door ons geformuleerde onderzoeksmodel sluiten wij ons aan bij de opvattingen over involvement als een moderator variabele (vergelijk cognitieve benadering). Het effect van tevredenheid op ware merktrouw is immers, volgens ons, mede afhankelijk van de motivatie van de consument om een merk te evaleren (te operationaliseren als de mate van involvement).

Bij de definities van involvement, waarbij wordt uitgegaan van een cognitieve benadering maar ook van een individuele toestandsbenadering, staan begrippen als 'relevance', 'interest' en 'importance' centraal. Het bekende onderscheid tussen 'high' en 'low' 
involvement impliceert dat ook bij dit begrip sprake is van een relatieve benadering waarmee de mate van involvement van een consument kan worden weergegeven.

De mate van involvement wordt door ons daarom gedefinieerd als:

\section{De mate van de interesse van een subject in een object.}

Met deze definitie wordt met name aangesloten bij de definitie van Hansen (1985). Het woord object wordt in het vervolg nog nader toegespitst op produkt en merkkeuze; dan wordt deze algemene definitie verbijzonderd (paragraaf 4.2.3).

Tot zover is alleen gekeken naar het algemene concept van involvement (vandaar dat nog slechts een algemene definitie van involvement is geformuleerd). In de literatuur worden vele specifieke soorten involvement onderscheiden. Dit gebeurt met name door gebruik te maken van voorvoegsels. De voorvoegsels geven aan waaraan de involvement moet worden gerelateerd of wat het object van de involvement is.

Houston en Rothschild (1978) constateren drie verschillende vormen van involvement: voortdurende-, situationele- en response-involvement. In 1978 definiëren Clark en Belk 'task' involvement. Vaughn introduceert in 1980 het begrip emotionele involvement. Belk (1982) besteedt expliciet aandacht aan de involvement bij 'gift-giving'. Bloch en Richins (1983) maken een verschil tussen voortdurende en situationele involvement. Park en Young (1983) maken een onderscheid tussen cognitieve en affectieve involvement. Antil (1984) en Muncy en Hunt (1984) definiëren ego-, communicatie-, response-, en aankoopinvolvement. Greenwald en Leavitt (1984) onderscheiden vier soorten 'audience' involvement: 'preattention', 'focal attention', 'comprehension' en 'elaboration'. Park en Young (1983) maken een onderscheid tussen cognitieve en affectieve involvement. Zaichowsky (1985) constateert een verschil tussen aankoop- en produktinvolvement. Beatty et al. (1988) onderscheiden ego- en aankoopinvolvement en Mittal en Lee (1989) maken een onderscheid tussen produkt-, en merkkeuze-involvement. Celsi en Olson (1989) introduceren het begrip felt involvement dat is opgebouwd uit situationele, en voordurende involvement. Maheswaran en Meyers-Levy (1990) bestuderen 'issue' involvement. Tot slot maken Cullen en Edget (1991) en Vadopivec (1991) eveneens een onderscheid tussen emotionele en cognitieve involvement (vergelijk Vaughn, 1980; Cohen, 1983; Park en Young, 1984; Park en Mittal, 1985; Zaichowsky, 1986; Ratchford, 1987 en Mittal, 1989a).

Het meest opvallende is dat steeds meer nadruk wordt gelegd op het onderscheid tussen emotionele- en cognitieve involvement enerzijds en het onderscheid tussen voortdurende en situationele involvement anderzijds. In het kader van ons onderzoek naar de relatie tussen tevredenheid en ware merktrouw is er voor gekozen geen expliciet onderscheid te maken tussen cognitieve- en emotionele involvement. De door ons gehanteerde definitie gaat uit van een algemene interesse in een produkt. Algemene interesse omvat, in onze opvatting, zowel cognitieve- als emotionele elementen.

Alvorens verder in te gaan op de verschillende soorten involvement, in termen van voortdurende involvement en situationele involvement en duidelijk te maken waarom in het onderzoek wordt met name uitgegaan van situationele involvement of involvement 
met de merkkeuze, zal eerst aandacht worden besteed aan de antecedenten en consequenties van involvement.

\subsubsection{Antecedenten en consequenties van involvement}

Zaichowsky (1986) geeft een conceptualisatie van involvement in relatie tot zowel de onafhankelijke als afhankelijke variabelen (antecedenten en consequenties). Deze wordt weergegeven in Figuur 4.1.

Figuur 4.1: Antecedenten en consequenties van involvement volgens Zaichowsky

Antecedenten van involvement afgeleid uit de literatuur
Mogelijke consequenties van involvement afgeleid uit de literatuur

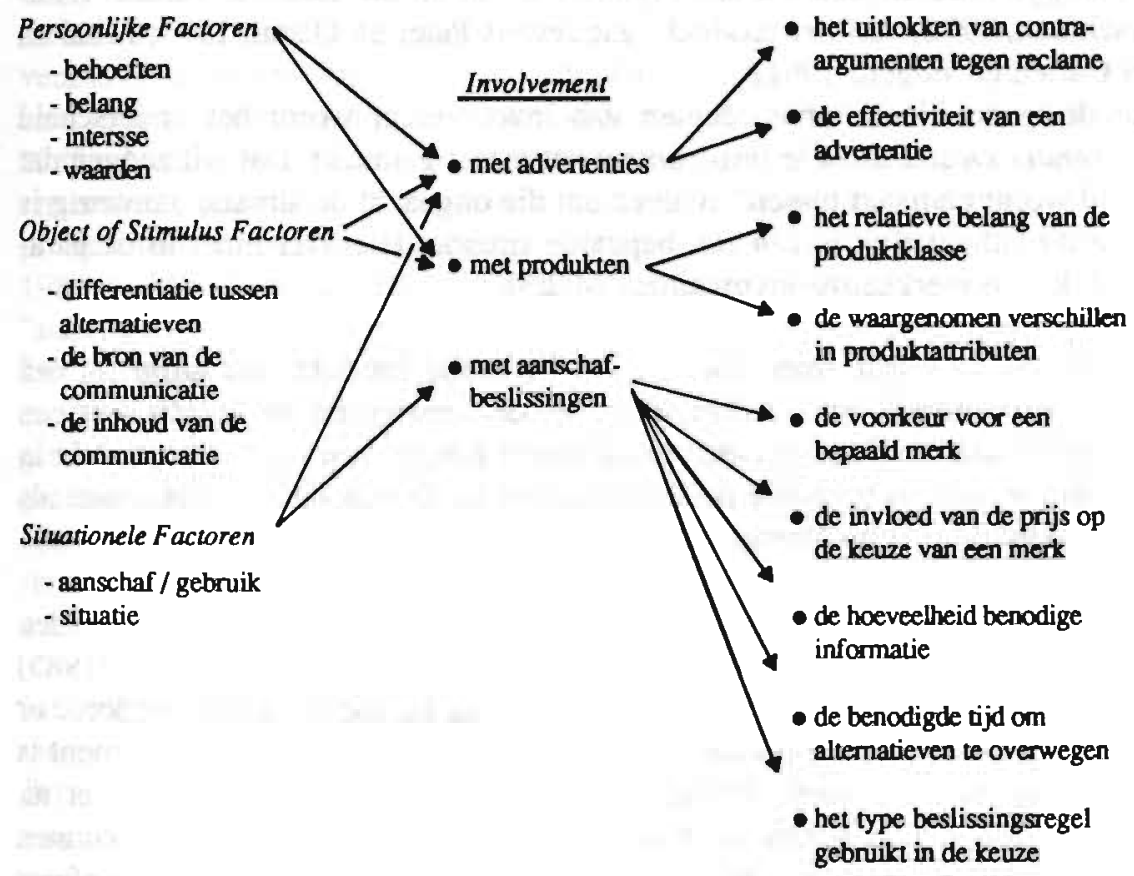

INVOLVEMENT $=\mathrm{f}$ (persoon, simatie, object)

Het niveau van involvement kan worden beïnvloed door én of meerdere van deze factoren. Interactie tussen personen, situaties en object-factoren kunnen zeer goed voorkomen.

Bron: Zaichowsky (1986), p. 6 


\subsection{2a Antecedenten van involvement nader toegelicht}

De belangrijkste antecedenten van involvement die in de literatuur worden aangetroffen zijn (Zaichowsky, 1985; zie tevens Houston en Rothschild, 1978; Belk, 1982 en Bloch en Richins, 1983):

- de persoon ('inherent interests, values or needs that motivate one to an object');

- het produkt ('characteristics of the object that cause differentiation and increase interest') en

- de situatie ('something that temporarily increases relevance or interest toward the object').

Ook komt het voor dat met name de situatie en de persoon (Celsi en Olson, 1989) of het produkt en de situatie (Poiesz en Pieters, 1987) als antecedenten worden gezien.

Ten aanzien van het produkt als antecedent van involvement, kan nog een onderscheid worden gemaakt voor wat betreft de 'utalitarian values' (Sheth, 1974) de 'sign values' (Sheth, 1974; Sirgy, 1982 en Laurent en Kapferer, 1985) en de 'hedonic values' (Holbrook en Hirschman, 1982) van het produkt. (Zie tevens Peter en Olson, 1987; Mital en Lee, 1989 en Cullen en Edgett, 1991).

Op basis van de verschillende antecedenten van involvement wordt het onderscheid tussen voortdurende- en situationele involvement het meest gemaakt. Dat wil zeggen dat een onderscheid wordt gemaakt tussen involvement die ongeacht de situatie aanwezig is en involvement die afhankelijk is van een bepaalde situatie. Hierover meer in de paragraaf over produkt- en merkkeuze-involvement (4.2.3).

Wellicht ten overvloede wordt erop gewezen dat hetzelfde produkt niet altijd tot een zelfde mate van involvement leidt. Afhankelijk van de persoon en de situatie kan een produkt in de ene situatie voor een persoon involverend zijn, terwijl datzelfde produkt in een andere situatie of voor een andere persoon dat niet is. Er bestaat dus niet zoiets als een universele produktklasse involvement (Ratz en Moore, 1989).

Wanneer het gaat om de antecedenten van involvement moet ook aandacht worden besteed aan de aspecten waaruit involvement is opgebouwd. Laurent en Kapferer (1985) onderscheiden vier aspecten: 'product importance', 'sign or symbolic value', 'hedonic or pleasure value' en 'brand risk'. Lastovicka en Gardner (1977) stellen dat involvement is opgebouwd uit 'familiarity', 'commitment' en 'normative importance'. Jensen et al. (1989) constateren dat bij involvement eveneens vier verschillende aspecten kunnen worden onderscheiden. Deze aspecten verschillen van de door Laurent en Kapferer (1985) onderscheiden aspecten; 'importance', 'knowledge', 'brand preference' en 'commitment'. Mittal en Lee (1989) onderscheiden zes aspecten die aan produkt involvement en brand involvement ten grondslag zouden liggen; 'product sign value', 'brand sign value', 'product hedonic value', 'brand hedonic value', 'product utility' en 'brand risk'. Wanneer ervan wordt uitgegaan dat involvement is opgebouwd uit verschillende aspecten, betekent dit, dat involvement moet worden opgevat als een multi-dimensioneel concept in plaats van een uni-dimensioneel concept. Dit betekent dat niet zonder meer gesproken kan worden over hoge of lage involvement, maar dat uitgegaan moet worden van een involvement profiel. 
Mittal (1989b) stelt echter toch dat involvement moet worden opgevat als een uni-dimensioneel concept. De reden dat Laurent en Kapferer involvement als een multidimensioneel concept beschouwen menen te moeten beschouwen, is in zijn ogen te verklaren door het feit dat zij de verschillende aspecten zelf in hun vragenlijst hebben ingebracht.

Voor het onderzoek naar de verklaring van ware merktrouw en de rol van tevredenheid daarbij is het onderscheid tussen de verschillende aspecten van involvement niet direct van belang. Bij dit onderzoek zal daarom worden uitgegaan van de unidimensionele opvatting van involvement. Dit betekent dat er vanuit wordt gegaan dat consumenten alleen meer of minder geïnvolveerd zijn en niet anders geïnvolveerd zijn.

\subsection{2b Consequenties van involvement nader toegelicht}

Involvement blijkt van invloed te zijn op nagenoeg alle facetten van het consumentengedrag. Diverse auteurs melden dat involvement positief van invloed is op 'media-exposure', 'response to a persuasion message', 'depth of processing advertising', de 'extensiveness of decision making' en 'worth of mouth communication' (Mitchell, 1979; Petty en Cacioppo, 1981; Batra en Ray, 1983; Park en Mittal, 1985 en Laurent en Kapferer, 1985). Tevens wordt een positief effect van involvement op 'extensiveness of the decision making process', 'interest in advertising', 'brand commitment' en 'frequency of product usage' gemeld (Laurent en Kapferer, 1985; Zaichowsky, 1985; Beatty en Smith, 1987 en Mittal en Lee, 1989). Verder laten Celsi en Olson (1989) zien dat involvement 'attention and comprehension' van consumenten in positieve zin richting geeft. Mittal en Lee (1989) constateren dat involvement positief van invloed is op 'shopping enjoyment' en 'social observations of product/brand usage'. Zaichowsky (1985) constateert een positieve relatie tussen involvement en 'perceived differences among brands', 'brand preferences', 'interest in gathering information about the product category' en 'comparison of product attributes among brands'. Tot slot mag niet onvermeld blijven dat Laurent en Kapferer (1985) de verwachting uitspreken dat er een positief effect van involvement op de 'willingness to reach a maximum or treshold level of satisfaction' zal zijn.

Involvement is, naast bovengenoemde facetten, ook nog van invloed op de manier waarop consumenten omgaan met reclame, produkten en aankoopbeslissingen. Vandaar dat ook wel een onderscheid wordt gemaakt tussen reclame-involvement, produkt-involvement en merkkeuze-involvement (Zaichowsky, 1986). Het toenemen van de reclameinvolvement leidt bijvoorbeeld tot het aanvoeren van meer tegenargumenten (Wright, 1973). De stijging van de produktinvolvement leidt onder meer tot de perceptie van meer en grotere verschillen tussen produktattributen (Howard en Sheth, 1969). Tot slot leidt de toename in de aankoopinvolvement tot bijvoorbeeld het zoeken van meer informatie en het besteden van meer tijd om het juiste produkt te vinden (Clarke en Belk, 1978).

In het kader van het onderzoek naar de verklaring van ware merktrouw en de rol van tevredenheid, is het verstandig nog even nader stil te staan bij de consequenties van involvement. 
Hoge involvement leidt tot het zien van grotere verschillen tussen produkten (Howard en Sheth, 1969; Hupfer en Gardner, 1971; Robertson, 1976; Lastovicka en Gardner, 1977 en Zaichowsky, 1985). In een situatie van hoge involvement worden produkten niet alleen op veel meer verschillende attributen met elkaar vergeleken dan in een situatie van lage involvement (Lastovicka en Gardner, 1977; Mitchell, 1979; Zaichowsky, 1985; Rothschild en Houston, 1986 en Belonax en Javalgi, 1989). Echter, bij hoge involvement is de 'zone of acceptance' per attribuut ook smaller dan bij lage involvement (Freedman, 1964; Sherif and Sherif, 1967; Jacoby, 1971 en Belonax en Javalgi, 1989). Het grotere aantal attributen waarop produkten met elkaar worden vergeleken tezamen met de smallere 'zone of acceptance' leidt bij hoge involvement tot een kleinere evoked set dan bij lage involvement (Petty, Cacioppo en Schumann, 1983 en Benolax en Javalgi, 1989). Consumenten die een hoge involvement ervaren, hebben een merk dat zij duidelijk prefereren boven andere merken (Zaichowsky, 1985). Bij lage involvement is het verschil tussen meest geprefereerde en andere merken kleiner.

Naarmate de involvement hoger is, stijgt naar verwachting het verlangen om een zo groot mogelijke tevredenheid te bereiken (Cardozo, 1965; Cohen en Goldberg, 1970; Woodside, 1972; Landon, 1977; Bloch en Richins, 1983; Crosby en Taylor, 1983 en Laurent en Kapferer, 1985). Er zijn echter (nog) geen concrete aanwijzingen dat de mate van tevredenheid toeneemt, wanneer de involvement hoger wordt.

Bij hoge involvement wordt de merkkeuze anders geëvalueerd dan bij lage involvement. Crosby en Taylor (1983) stellen namelijk dat bij hoge involvement een consument er toe geneigd is zijn/haar voorkeur te handhaven en deze bevestigd te zien. Bij hoge involvement, waarbij nog geen sprake is van commitment aan het merk, wordt het merk desondanks uitgebreid geëvalueerd. Bij hoge involvement, waarbij wel sprake is van commitment aan het merk, wordt voornamelijk bevestiging van de eigen voorkeur gezocht. In geval van lage betrokkenheid zal er niet of nauwelijks sprake zijn van evaluatie van het merk (zie tevens: Day, 1977; Swan en Trawick, 1979; en Engel et al., 1986).

In de literatuur wordt een directe en positieve relatie geconstateerd tussen involvement (met name produktkeuze-involvement) en commitment (Sherif, Sherif and Nebergall, 1965; Howard en Sheth, 1969; Lastovicka en Gardner, 1977; Crosby en Taylor, 1983; Zaltman en Wallendorf, 1983; Laurent en Kapferer, 1985; Zaichowsky, 1985; Beatty en Smith, 1987; Beatty et al., 1988; Mittal en Lee, 1989 en Goldsmith et al., 1991). In een groot aantal van deze studies wordt commitment conceptueel gelijk gesteld met merktrouw en wordt er verondersteld dat er dientengevolge een positieve relatie bestaat tussen involvement en merktrouw (Jacoby, 1971). Deze redenering is ons inziens niet terecht omdat nu principaal verschillende concepten aan elkaar gelijk worden gesteld (zie tevens paragraaf 4.3).

Involvement blijkt van invloed te zijn op veel facetten van het consumentengedrag. Geenszins is in dit verband dan ook geprobeerd een volledig overzicht te verschaffen. Wel is geprobeerd de meest belangwekkende verbanden in het kader van het onderzoek naar voren te halen. Voor ons onderzoek is het hiernaast wezenlijk een onderscheid aan te brengen tussen involvement bij het produkt ('product involvement') en involvement 
bij de merkkeuze ('brand choice involvement'), welke te vergelijken is met voortdurende en situationele involvement.

\subsubsection{Produktinvolvement en merkkeuze-involvement}

In het kader van het onderzoek naar de verklaring van ware merktrouw en de rol van tevredenheid hierbij is met name het onderscheid dat wordt gemaakt tussen produktinvolvement en merkkeuze-involvement van betekenis. Het totale begrippenkader kan op grond van de definities van de verschillende soorten involvement, volgens ons, sterk kan worden beperkt. Deze beperking wordt gemaakt door te stellen dat produktinvolvement nagenoeg overeenkomt met voortdurende involvement en dat voortdurende involvement nagenoeg overeenkomt met ego-involvement. Daarnaast wordt gesteld dat merkkeuzeinvolvement nagenoeg overeenkomt met situationele involvement en dat situationele involvement nagenoeg overeenkomt met aankoopinvolvement. Wij prefereren een onderscheid te maken tussen produktinvolvement en merkkeuze-involvement omdat dit, gezien de doelstelling van het onderzoek, qua terminologie, beter aansluit dan het onderscheid tussen voortdurende en situationele involvement. Wij zullen deze redenering nu verder toelichten.

Het werk van Houston en Rothschild (1978), Bloch en Richins (1983), Zaichowsky (1985), Beatty et al. (1988) en Mittal en Lee (1989) wordt door deze beperking, voor wat betreft het begrippenkader, op één lijn geplaatst.

Beatty et al. (1988, p. 150) definiëren ego-involvement als 'the importance of the product to the individual and to the individual's self concept, values and ego'. Daarmee is ego involvement min of meer gelijk aan de voortdurende involvement van Houston en Rothschild (1978) en de voortdurende involvement van Bloch en Richins (1983). Voortdurende involvement wordt door Houston en Rothschild (1978) gedefinieerd als "the ongoing concern for a product class' en Bloch en Richins (1983) stellen met betrekking tot voortdurende involvement dat het: "is independent of purchase situations and is motivated by the degree of which the product relates to the self - or the hedonic pleasure received from the product".

Aankoopinvolvement wordt door Beatty et al. $(1988$, p. 150) gedefinieerd als 'the level of concern for, or interest in, the purchase process triggered by the need to consider a particular purchase'. Aankoopinvolvement is hiermee iets beperkter dan situationele involvement van Houston en Rothschild (1978) omdat aankoopinvolvement slechts refereert aan de situatie waarin een aankoop aan de orde is. Desalniettemin stemmen beide soorten involvement in belangrijke mate met elkaar overeen.

Mittal en Lee (1988) wijzen erop dat het door hen gehanteerde onderscheid tussen produktinvolvement en merkkeuze-involvement (vergelijk Bloch, 1983; Bloch en Richins, 1983 en Zaichowsky, 1985 en 1986) samen valt met het onderscheid dat door Zaichowsky (1985) wordt aangebracht tussen produktinvolvement en aankoopinvolvement. Tevens wordt met het onderscheid tussen produktinvolvement en merkkeuzeinvolvement aangesloten bij 'perceived product importance' en 'perceived risk associated with the product's purchase', als antecedenten van involvement die door Laurent en Kapferer (1985) zijn geformuleerd. Mittal en Lee (1988) definiëren produktinvolvement 
als 'the degree of interest of a consumer in a product category on an ongoing basis' en merkkeuze-involvement als 'the motivation of a consumer to make the right choice'. Mittal (1989c) stelt dat produktinvolvement gezien wordt als 'product importance' (Hupfer en Gardner, 1971 en Lastovicka en Gardner, 1977) en als voortdurende involvement (Houston en Rothschild, 1978 en Bloch, 1981). Aankoopinvolvement moet volgens Mittal (1989c, p. 150) worden gedefinieerd als "the extent of interest and concern that a consumer brings to bear upon a purchase-decision task". Aankoopinvolvement zou daarmee analoog zijn aan situationele involvement zoals gedefinieerd door Houston en Rothschild (1978).

Produktinvolvement kan gedefinieerd worden als 'interest in the product class' en merkkeuze-involvement kan gedefinieerd worden als 'interest in the brand decision' (Mittal en Lee, 1989). $\mathrm{Zij}$ menen dat produktinvolvement voortdurend aanwezig is, terwijl merkkeuze-involvement zich beperkt tot de situatie waarin de merkkeuze plaatsvindt. Een consument kan dus geïnvolveerd zijn bij de merkkeuze zonder dat deze geïnvolveerd is bij het produkt. Wanneer een consument echter geïnvolveerd is bij het produkt zal hij/zij ook geïnvolveerd zijn bij de merkkeuze.

In het kader van het onderzoek naar de verklaring van ware merktrouw wordt door ons involvement bij de merkkeuze het belangrijkste geacht. Het is niet zozeer van belang of een consument voortdurend geïnteresseerd is in een produkt maar of de consument geïnteresseerd is in de merkkeuze van een produkt. Onze eerdere definitie van involvement wordt daarom aangescherpt en vervangen door de definitie van de mate van involvement bij de merkkeuze:

De mate van interesse van een subject in de merkkeuze van een produkt.

Wij gaan er vanuit dat merkkeuze-involvement een rol speelt bij de verklaring van ware merktrouw (als operationalisatie van motivatie). Merkkeuze-involvement heeft in tegenstelling tot produktinvolvement direct betrekking op de koopsituatie. Consumenten die geïnvolveerd zijn bij het produkt zijn in ieder geval geïnvolveerd bij de merkkeuze. Omgekeerd hoeft dit niet zo te zijn. (Een consument die ongeacht de situatie geïnvolveerd is, is ook geïnvolveerd in een specifieke situatie; een consument die in een specifieke situatie geïnvolveerd is, hoeft dit niet in elke situatie te zijn.)

Geconcludeerd kan worden dat in de literatuur vele soorten involvement worden onderscheiden. De literatuur wordt hierdoor erg ondoorzichtig. Een aanmerkelijke verbetering treedt op indien gesteld wordt dat produktinvolvement zo goed als gelijk is aan voortdurende involvement en dat voortdurende involvement zo goed als gelijk is aan ego-involvement en dat tevens gesteld kan worden dat merkkeuze-involvement zo goed als gelijk is aan situationele involvement en dat situationele involvement zo goed als gelijk is aan aankoopinvolvement. De vele verschillende soorten zijn hiermee tot twee varianten teruggebracht: produktinvolvement en merkkeuze-involvement. Bij het onderzoek naar ware merktrouw staat de merkkeuze-involvement centraal. 


\subsubsection{Operationalisatie van involvement}

De schalen (of delen van de schalen) van de volgende schalen zijn, volgens ons, met name geschikt om merkkeuze-involvement te meten: Laurent en Kapferer (1985); Zaichowsky (1985); Ratchford (1987); Mittal en Lee (1988; 1989); Mittal (1989c); Cullen en Edgett (1991) en Verplanken (1991). Deze hebben wij ook gehanteerd bij de constructie van onze vragenlijst (zie paragraaf 5.4).

In de literatuur worden echter ook nog andere schalen aangeboden waarmee involvement kan worden gemeten. Verwezen wordt naar Lastovicka en Gardner (1977); Bloch (1981); Slama en Tashian (1985); Rothschild en Houston (1986); McQuarrie en Munson (1987) en Beatty et al. (1988).

\subsection{Afbakening van commitment en involvement}

Allereerst moet worden opgemerkt dat commitment en involvement in de literatuur niet altijd duidelijk van elkaar worden onderscheiden. Het komt veelvuldig voor dat beide termen als synoniemen worden gebruikt. Ook komt het voor dat hetgeen door de ene auteur als commitment wordt benoemd, door een ander als involvement wordt benoemd. Er bestaat dus verwarring ten aanzien van de definiëring van beide concepten. Toch is het ons inziens mogelijk een goed conceptueel en operationeel onderscheid te maken tussen involvement en commitment.

Overeenkomstig de opvatting van Beatty et al. (1988) stellen Crosby en Taylor (1983) dat een persoon geïnvolveerd kan zijn bij een object, zonder gecommitteerd te zijn aan dat object. Dit wil zeggen dat een consument interesse kan hebben bij de merkkeuze zonder dat deze consument duidelijk stelling neemt ten aanzien van de merkkeuze en aan deze merkkeuze wil vast houden.

Het verschil tussen involvement en commitment is volgens Crosby en Taylor (1983) gebaseerd op het feit dat involvement bij de merkkeuze voortkomt uit belangrijke waarden en zelf-concepten van een persoon in een beslissingssituatie. Commitment ontstaat pas als waarden, zelf-concepten of belangrijke attitudes worden verbonden met een specifieke keuze.

\subsection{Deliberatie}

\subsubsection{Conceptualisatie van deliberatie}

In de literatuur kan geen definitie van deliberatie worden gevonden. De reden hiervoor is dat deliberatie een concept is dat door ons, bij het onderzoek naar de verklaring van ware merktrouw, wordt geïntroduceerd. Deliberatie heeft betrekking op de capaciteit om na te denken over de merkkeuze. De mate van deliberatie wordt door ons gedefinieerd als:

De mate waarin een subject kan nadenken over de merkkeuze. 
In de literatuur zijn geen schalen voor handen waarmee deliberatie kan worden gemeten. Als gevolg hiervan hebben wijzelf een schaal voor het meten van deliberatie ontwikkeld (zie paragraaf 5.4).

\subsection{Elaboratie en het Elaboration Likelihood Model}

Zowel de verklaring van ware merktrouw, als de rol die tevredenheid daarbij speelt, worden verondersteld afhankelijk te zijn van de uitgebreidheid waarmee evaluatie- en beslissingsprocessen zijn doorlopen. De uitgebreidheid waarmee evaluatie- en beslissingsprocessen worden doorlopen, wordt ook wel elaboratie genoemd.

In de literatuur wordt elaboratie gedefinieerd als:

'Issue relevant thinking' (Petty en Cacioppo, 1986)

Wij sluiten ons aan bij deze definitie. Elaboratie wordt echter ook wel gedefinieerd als 'the amount of integration between the stimulus and existing knowledge (Engel, Blackwel en Miniard, 1990) of als 'the number of personal connections made between the stimulus and one's life experiences and goals' (Krugman, 1966).

Het Elaboration Likelihood Model (Petty, Cacioppo en Schumann, 1983) geeft inzicht in de rol van de mate van elaboratie bij het ontstaan van attitudeveranderingen en zal daarom kort worden toegelicht (vrij naar Pieters, Verplanken en Modde, 1987).

In het Elaboration Likelihood Model (ELM) worden twee routes onderscheiden die leiden tot attitudeverandering na blootgesteld te zijn geweest aan communicatie. De eerste route tot attitudeverandering, de centrale route, betekent een grondige en zorgvuldige afweging van de argumenten in een boodschap. Op deze route vindt een uitgebreid en diepgaand informatieverwerkingsproces plaats (veel elaboratie). Indien er een attitudeverandering optreedt, is dit (a) een duurzame attitudeverandering, (b) een attitudeverandering die direct van invloed is op gedrag en (c) een attitudeverandering die niet gemakkelijk weer te veranderen is. De tweede route tot attitudeverandering, de perifere route, vindt plaats onder invloed van eenvoudige 'cues' in de context van de boodschap. Deze 'cues' betreffen bijvoorbeeld de geloofwaardigheid van de bron, het aantal argumenten (in plaats van de kwaliteit) of het aantal malen dat de boodschap herhaald wordt. Op deze route heeft slechts een simpel, oppervlakkig informatieverwerkingsproces plaats (weinig elaboratie). Als er al een attitude verandering, via deze route, optreedt, is dit slechts een tijdelijke attitudeverandering, die niet altijd van invloed is op gedrag en die gemakkelijk opnieuw te veranderen is.

In het ELM zijn twee factoren bepalend of de centrale of de perifere route naar attitudeverandering wordt gevolgd:

1 de motivatie van de consument om over de boodschap na te denken;

2 de capaciteit van de consument om over de boodschap na te denken. 
De motivatie wordt ook wel geoperationaliseerd met situationele- of merkkeuze-involvement (Petty, Cacioppo en Schumann, 1983). De capaciteit van de consument is 'de tendens van het individu om cognitieve inspanningen te verrichten' (Cacioppo en Petty, 1982) soms ook wel aangeduid als 'need for cognition' (Cacioppo en Petty, 1982; Verplanken, 1989 en 1991) of zoals door ons gedefinieerd 'de mate waarin een subject (kan) nadenken over de merkkeuze'.

Wij veronderstellen dat de mate van elaboratie van een consument kan worden vastgesteld op basis van diens merkkeuze-involvement (motivatie) en diens deliberatie (capaciteit). 


\subsection{Doelstelling}

De doelstelling van het vooronderzoek is tweeledig. Enerzijds is het de bedoeling schalen te construeren voor het betrouwbaar en valide meten van commitment, merkkeuzeinvolvement en deliberatie met behulp van Nederlands talige items. Anderzijds is het doel een eerste inventarisatie te maken van de relaties tussen de verschillende variabelen voor wat betreft verschillende produkten.

In dit hoofdstuk zal de nadruk liggen op de eerste doelstelling van het vooronderzoek: het construeren van Nederlands talige schalen voor het meten van commitment, merkkeuze-involvement en deliberatie.

\subsection{Vragenlijst}

Om de doelstellingen van het vooronderzoek te kunnen verwezenlijken, is gebruik gemaakt van een schriftelijke vragenlijst. Deze vragenlijst bestaat uit vier onderdelen. Onderdeel I bevat 80 vragen met betrekking tot merktrouw, tevredenheid, commitment, merkkeuze-involvement en deliberatie die specifiek gericht zijn op cassettebandjes. Onderdeel II bevat deze vragen echter nu over jeans. Onderdeel III bevat eveneens dezelfde vragen maar nu gericht op frisdrank. Onderdeel VI bevat achtergrondvariabelen en vragen over merktrouw in het algemeen. De vragenlijst was aldus vrij omvangrijk, namelijk in totaal 334 vragen in verdeeld over vier onderdelen.

Cassettebandjes, jeans en frisdrank zijn gekozen omdat naar verwachting de gemiddelde mate van commitment, merkkeuze-involvement, deliberatie en merktrouw ten aanzien van deze produkten van elkaar zal verschillen. Ten aanzien van tevredenheid is het moeilijker vooraf een verschil tussen de produkten te vooronderstellen. Bovendien zijn het produkten die redelijk frequent door vrijwel de gehele bevolking worden gekocht.

\subsection{Steekproef}

Aan tweedejaars studenten economie van de Faculteit der Economische Wetenschappen der Rijksuniversiteit Limburg $(\mathrm{N}=518)$ is gevraagd de schriftelijke vragenlijst in te vullen. Honderdveertig ingevulde vragenlijsten zijn retour gekomen. Dit kwam neer op een responspercentage van $27 \%$. Alle ingevulde vragenlijsten werden bruikbaar voor analyse bevonden. 


\subsubsection{Item-verzameling}

Commitment wordt gemeten met een 5-punts Likert-schaal. Hierin zijn alle (7 stuks) verschillende relevante en bekende items uit de literatuur opgenomen (Lastovicka en Gardner, 1977; Beatty et al., 1988 en Mittal en Lee, 1989). Het betreft hier immers een vooronderzoek met als doelstelling te komen tot een zo goed mogelijke Nederlandstalige schaal voor het meten van commitment (zie Churchill, 1979 en Green et al. 1988 voor het ontwikkelen van schalen). Voor een overzicht zie Bijlage 3.

Merkkeuze-involvement wordt gemeten met een 5-punts Likertschaal en een semantische differentiaal. Zowel in de Likertschaal als in de semantische differentiaal zijn alle mogelijk verschillende items opgenomen.

De Likertschaal voor het meten van merkkeuze-involvement is in eerste instantie gebaseerd op de schaal van Mital en Lee (1989), die merkkeuze-involvement meet. Voorts is de schaal aangevuld met enige vragen die betrekking hebben op affectieve involvement en zijn vragen uit andere schalen verwerkt voor zover verwacht werd dat aspecten van deze vragen onvoldoende in de schaal van Mital en Lee naar voren zouden komen. Met name vragen die speciaal betrekking hebben op de verschillende dimensies van involvement: perceived risk, perceived importance, sign value, hedonic value en risk probability. De oorspronkelijk lijst bevat 28 items. Bijlage 4 bevat een overzicht van de in de vragenlijst opgenomen items.

De semantische differentiaal voor het meten van merkkeuze-involvement is in eerste instantie gebaseerd op de semantische differentiaal voor het meten van produktinvolvement van Zaichowsky (1985). Deze is aangevuld met items van McQuarrie en Munson (1987) voor wat betreft die dimensies die niet in de schaal van Zaichowsky aanwezig zouden zijn en die tevens duidelijk aansluiten bij de verschillende dimensies van involvement die door Laurent en Kapferer (1985) worden onderscheiden. In totaal bevat de schaal 28 items. Volgens Zaichowsky kan de produktinvolvementschaal zonder aanpassing van de items ook worden gebruikt voor het meten van merkkeuze-involvement, zoals door ons is gedaan. In Bijlage 5 wordt een overzicht gegeven van de in de vragenlijst opgenomen items.

Deliberatie wordt eveneens gemeten met een 5-punts Likertschaal. Nu echter gebaseerd op ideeën van Chaiken (1980), Batra en Ray (1983), Sujan (1985) en Maheswaran en Meyers-Levy (1990) met betrekking tot deliberatie. Omdat deze items direct aansloten bij onze onderzoeksdoelstellingen zijn door ons zelf items geformuleerd. Deze 6 items opgenomen in Tabel 5.10.

Voor drie van de behandelde schalen (commitment, merkkeuze-involvement (Likertschaal en semantische differentiaal)) geldt dat in de bijlagen alle items zijn weergegeven, die in de vragenlijst van dit vooronderzoek zijn opgenomen. De items van de deliberatieschaal staan alleen vermeld in Tabel 5.10 omdat er geen discrepantie is tussen 
de aanvankelijke items die in het vooronderzoek zijn opgenomen en de uiteindelijk geselecteerde items.

Voor elk van de schalen geldt dat in eerste instantie zo veel mogelijk relevante items zijn verzameld. Vervolgens is uit deze items een selectie gemaakt door alle items te verwijderen, die in de oorspronkelijke schalen met elkaar overeenkomen. De na deze selectie overgebleven items, zijn in het Nederlands vertaald. Door een drietal inhoudsdeskundigen (ten aanzien van schaalconstructie en de inhoud van de concepten waarop de schalen betrekking hebben) zijn vervolgens de meest geschikte items geselecteerd. De concept-vragenlijst, met daarin de vier schalen, is vervolgens aan een twintigtal respondenten voorgelegd. Aan deze respondenten is gevraagd de vragenlijst en de afzonderlijke items kritisch te evalueren. Dit heeft geleid tot enkele aanpassingen in de formulering van de items en de volgorde waarin de items worden gepresenteerd (vergelijk tevens Nunnally, 1987 voor de constructie van schalen).

Over de oorspronkelijke (Engelstalige) schalen is vaak nauwelijks in termen van betrouwbaarheid en validiteit gerapporteerd. Voor wat het meten van merkkeuze-involvement betreft is de schaal van Mittal en Lee (1989) betrouwbaar bevonden in termen van interne consistentie en is vastgesteld dat deze schaal over voldoende discriminerende validiteit beschikt. De schaal van Zaichowsky (1985), feitelijk ontwikkeld voor het meten van produktinvolvement, is de enige die uitvoerig is gevalideerd. De construct-, de criterium- en de inhoudsvaliditeit worden ruim voldoende bevonden. Bovendien blijkt de schaal betrouwbaar (Cronbach-alpha $=.90$ ).

Met betrekking tot het meten van commitment blijkt alleen de face validiteit vastgesteld te zijn van de commitmentschaal van Beatty et al. (1988).

Wij zullen daarentegen nadrukkelijk aandacht besteden aan de betrouwbaarheid en de validiteit van de in ons onderzoek te gebruiken schalen.

\subsubsection{Item-selectie en betrouwbaarheid van de schalen}

Eén van de doelstellingen van het vooronderzoek is te komen tot een betrouwbare en valide meting van commitment, merkkeuze-involvement en deliberatie. Het aantal in de vragenlijst opgenomen items moet daarom gereduceerd worden tot die items, uiteraard per schaal, die er voor zorgen dat uiteindelijk een betrouwbare en valide schaal ontstaat om de 3 afzonderlijke concepten te meten. Per schaal zal worden besproken hoe hierbij te werk is gegaan.

Bij de presentatie van de resultaten per schaal en de conclusies, worden de resultaten die betrekking hebben op cassettebandjes als uitgangspunt genomen omdat de resultaten over de produkten heen, nagenoeg identiek zijn. Indien het volgens ons noodzakelijk is deze conclusies aan te passen, als gevolg van andere resultaten ten aanzien van jeans en frisdrank, zal hiervan apart melding worden gemaakt. 
Alle items van de commitmentschaal (Bijlage 3) over cassettebandjes zijn in eerste instantie aan de volgende criteria ter verwijdering onderworpen:

1 vaker dan 5 keer een respondent met weet niet/geen mening en/of;

2 item-totaal correlatie lager dan .50 (Green et al. 1988) en/of;

3 geen verschil in gemiddelde per item voor wat betreft de score op dit item in het hoogste en laagste kwartiel (Green et al., 1988).

Vervolgens is nog een vierde criterium ter verwijdering toegepast (nadat elk van de items op de verschillende te construeren schalen (commitment, merkkeuze-involvement en elaboratie) aan de vorige criteria was onderworpen):

4 correlatie tussen items op verschillende schalen (commitment en merkkeuze-involvement én commitment en elaboratie) hoger dan .70 (Bijlage 6).

Alle items, op één na blijven op basis van deze criteria behouden (Tabel 5.1).

Tabel 5.1: Schaal voor het meten van commitment*

Itemnr.

1 Ik vind mezelf zeer trouw ten opzichte van een bepaald merk frisdrank.

2 Wanneer een ander merk frisdrank in de aanbieding is, koop ik dat eerder dan mijn gebruikelijke merk.

3 Wanneer het merk frisdrank waaraan ik de voorkeur geef niet verkrijgbaar is in de winkel dan koop ik een willekeurig ander merk dat wel verkrijgbaar is.

4 Wanneer het merk frisdrank waaraan ik de voorkeur geef niet verkrijgbaar is in de winkel dan koop ik een ander merk dat ik net zo goed vind.

5 Wanneer het merk frisdrank waaraan ik de voorkeur geef niet verkrijgbaar is in de winkel dan ga ik naar een andere winkel om het daar te kopen.

$6 \mathrm{Als}$ ik van plan ben een bepaald merk frisdrank te kopen, is het nog gemakkelijk om mij van gedachten te doen veranderen en feitelijk een ander merk te kopen.

*: frisdrank als produkt kan door elk ander produkt worden vervangen.

De betrouwbaarheid van de schaal - in termen van interne consistentie (Peter, 1979) wordt voor de verschillende produkten weergegeven in Tabel 5.2. Tabel 5.3 geeft een overzicht van de item-totaal correlaties.

Tabel 5.2: Overzicht Cronbach-alpha commitment zoals gemeten bij de drie produkten (zes geselecteerde items).

\begin{tabular}{lll}
\hline & Cronbach-alpha & $\mathrm{n}$ \\
\hline cassettebandjes & .87 & 90 \\
jeans & .78 & 87 \\
frisdrank & .76 & 126 \\
\hline
\end{tabular}

$\mathrm{n}$ : aantal respondenten in de analyse 
Tabel 5.3: Overzicht item-totaal correlatie commitment zoals gemeten bij de drie produkten (zes geselecteerde iterns).

\begin{tabular}{llll}
\hline Itemnr. & Cassettebandjes & Jeans & Frisdrank \\
\hline 1 & .61 & .40 & .46 \\
2 & .74 & .65 & .61 \\
3 & .73 & .64 & .58 \\
4 & .51 & .50 & .31 \\
5 & .69 & .60 & .50 \\
6 & .72 & .39 & .54 \\
\hline
\end{tabular}

Geconcludeerd kan worden dat de items gezamenlijk een redelijk betrouwbare maat vormen voor het meten van commitment omdat Cronbach-alpha groter is dan .70 en de meeste item-totaalcorrelaties groter zijn dan .50 (Tabachnick en Fidell, 1989). Op grond hiervan gaan wij er tevens vanuit dat commitment gemeten kan worden als een simpele lineaire combinatie van individuele items (Comrey, 1973).

\section{Merkkeuze-involvement: Likertschaal}

Alle items op de Likertschaal voor het meten van merkkeuze-involvement (Bijlage 4) ten aanzien van cassettebandjes, zijn aan dezelfde criteria ter verwijdering onderworpen als de items op de Likertschaal voor het meten van commitment (zie tevens Bijlage 6). Als resultaat blijven 11 items over (zie Tabel 5.4).

Tabel 5.4: Schaal voor het meten van merkkeuze-involvement*

Itemnr.

1 De keuze van een bepaald merk frisdrank is voor mij niet belangrijk.

2 Ik voel me niet betrokken bij de merkkeuze van frisdrank.

5 Ik ben erg geïnteresseerd in het kiezen van het juiste merk frisdrank.

6 Ik kies zorgvuldig een bepaald merk frisdrank uit.

7 Het kan me niet schelen welk merk frisdrank ik kies.

8 Ik neem de keuze van een merk frisdrank serieus.

9 Het is voor mij niet belangrijk dat ik me tevreden voel bij de keuze van een bepaald merk frisdrank.

12 Het maakt geen verschil welk bepaald merk frisdrank ik kies.

17 Persoonlijk is voor mij de keuze van bepaald merk frisdrank niet relevant.

20 Van de keuze van een verkeerd merk frisdrank, heb ik spijt.

23 Ik maak me niet druk over welk merk frisdrank ik kies.

*: frisdrank als produkt kan door elk ander produkt worden vervangen; itemnr. in aansluiting op Bijlage 4.

De betrouwbaarheid (de interne consistentie) van de schaal is getoetst met Cronbachalpha (Tabel 5.5). Tabel 5.6 geeft een overzicht van de item-totaal correlaties. 
Tabel 5.5: Overzicht Cronbach-alpha meerkkeuze-involvement zoals gemeten bij de drie produkten (11 geselecteerde items).

\begin{tabular}{lll}
\hline & Cronbach-alpha & $\mathrm{n}$ \\
\hline cassettebandjes & .90 & 86 \\
jeans & .93 & 86 \\
frisdrank & .87 & 128 \\
\hline
\end{tabular}

$\mathrm{n}$ : aantal respondenten in de analyse

Tabel 5.6: Overzicht item-totaal correlatie merkkeuze-involvement zoals gemeten bij de drie produkten (11 geselecteerde items).

\begin{tabular}{llll}
\hline Itemnr. & Cassettebandjes & Jeans & Frisdrank \\
\hline 1 & .69 & .74 & .62 \\
2 & .54 & .64 & .61 \\
5 & .63 & .79 & .63 \\
6 & .70 & .84 & .68 \\
7 & .75 & .84 & .78 \\
8 & .66 & .76 & .58 \\
9 & .54 & .48 & .34 \\
12 & .66 & .67 & .59 \\
17 & .70 & .77 & .52 \\
20 & .56 & .55 & .48 \\
23 & .65 & .78 & .53 \\
\hline
\end{tabular}

Ook hier kan geconcludeerd worden dat de 11 items gezamenlijk een betrouwbare maat vormen voor het meten van merkkeuze-involvement omdat Cronbach-alpha duidelijk groter is dan .70 en vrijwel alle item-totaal correlaties groter zijn dan .50 (Tabachnick en Fidell, 1989).

Vervolgens is een factoranalyse (PCA met varimax rotatie; selectie criterium voor de factoren: eigenwaarde groter dan 1) uitgevoerd met als input de 11 items betreffende de cassettebandjes. Deze factoranalyse is bedoeld om te checken of er een specifieke structuur in deze 11 items is te ontdekken. Dat wil zeggen dat wordt nagegaan of merkkezue-involvement inderdaad kan worden opgevat als een uni-dimensioneel concept. Op basis van de literatuur zou hierover twijfel kunnen bestaan, aangezien hierin verschillende dimensies worden onderscheiden.

De resultaten van deze analyse geven aan dat er drie factoren te onderkennen zouden zijn (Tabel 5.7); echter er is steeds maar éen factor met een eigenwaarde die ver boven de één ligt. Met andere woorden: er is maar één duidelijke factor aanwezig. 
Tabel 5.7: Overzicht factoren in de merkkeuze-involvementschaal

\begin{tabular}{llll}
\hline Factor & Eigenwaarde & Perc Var* & Cum Perc** \\
\hline Cassettebandjes & & & \\
1 & 5.39 & 49.0 & 49.0 \\
2 & 1.05 & 9.5 & 58.5 \\
3 & 1.02 & 9.3 & 67.8 \\
Jeans & 7.11 & 64.6 & 64.6 \\
1 & & & \\
Frisdrank & 5.36 & 48.7 & 48.7 \\
1 & 1.22 & 11.1 & 59.8 \\
2 & & & \\
\hline
\end{tabular}

*: percentage verklaarde variantie; **: cumulatief percentage verklaarde variantie

Gelet op de hoge interne consistentie van de schaal en het feit dat bovendien alle 11 items bij elk produkt op de eerste factor laden, gaan wij er bij de verdere schaalconstructie, van uit dat deze 11 items één merkkeuze-involvementschaal representeren. Daarnaast gaan wij op grond hiervan er tevens van uit dat merkkeuze-involvement gemeten kan worden als een simpele lineaire combinatie van de individuele items (Comrey, 1973). Voor een uitgebreid overzicht van de resultaten van de factoranalyse per produkt wordt verwezen naar Bijlage 7.

\section{Merkkeuze-involvement: semantische differentiaal}

De items van de semantische differentiaal met betrekking tot cassettebandjes zijn aan de volgende twee criteria ter verwijdering onderworpen:

1 item-totaal correlatie lager dan .50 (Green et al., 1988);

2 geen verschil in gemiddelde per item voor wat betreft de score op dit item in het hoogste en laagste kwartiel (Green et al., 1988).

Op grond hiervan worden zeven items verwijderd en blijven dus 21 items over (Tabel 5.8). 


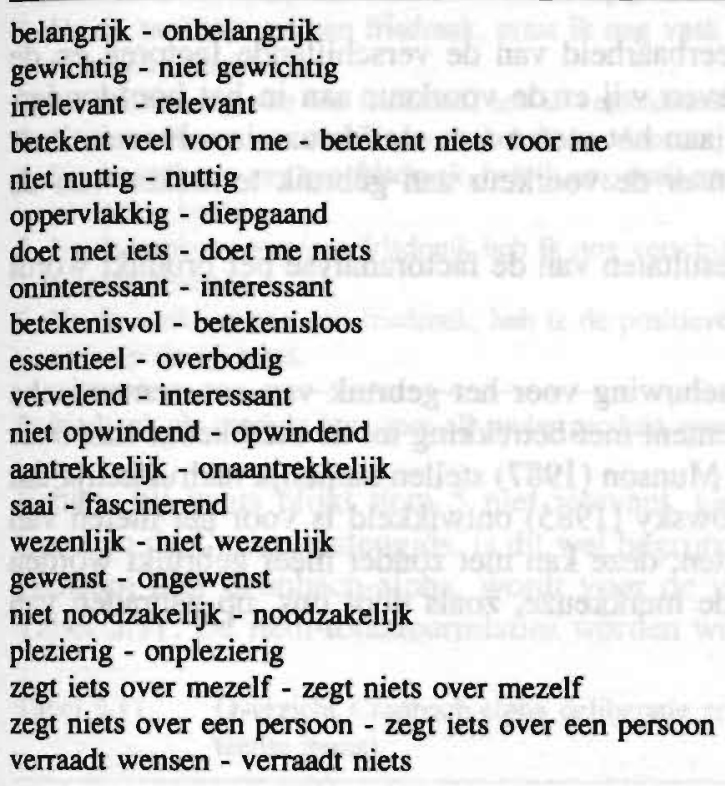

Factor analyse (PCA met varimax rotatie: selectie criterium voor de factoren; eigenwaarden groter dan 1) op deze overgebleven items levert verschillende factor-oplossingen voor de verschillende produkten op (zie Tabel 5.9).

Tabel 5.9: Overzicht factoren in de merkkeuze-involvementschaal

\begin{tabular}{lrrl}
\hline Factor & Eigenwaarde & Perc Var* & Cum Perc** \\
\hline Cassettebandjes & & & \\
1 & 7.75 & 36.9 & 36.9 \\
2 & 2.54 & 12.1 & 49.0 \\
3 & 1.49 & 7.1 & 56.1 \\
4 & 1.12 & 5.3 & 61.5 \\
5 & 1.10 & 5.2 & 66.7 \\
Jeans & & & \\
1 & 11.65 & 55.5 & 55.5 \\
2 & 1.88 & 9.0 & 64.4 \\
3 & 1.41 & 6.7 & 71.1 \\
Frisdrank & & & 50.8 \\
1 & 10.67 & 50.8 & 59.4 \\
2 & 1.79 & 8.5 & 66.2 \\
3 & 1.45 & 6.9 & \\
\hline
\end{tabular}

*: percentage verklaarde variantie; **: cumulatief percentage verklaarde variantie

Bij cassettebandjes blijkt dat belangrijk, relevant, nuttig, essentieel, noodzakelijk en wenselijk scoren hoog op factor 1 . Doet me iets, betekenisvol en opwindend scoren hoog op factor 2. Interessant (vervelend), fascinerend en plezierig scoren hoog op factor 
3. Diepgaand en interessant (oninteressant) scoren hoog op factor 4 en aantrekkelijk en wezenlijk scoren hoog op factor 5 .

Gezien de problemen met de interpreteerbaarheid van de verschillende factoren en de variantie over de drie de produkten, geven wij er de voorkeur aan in het hoofdonderzoek geen nadere aandacht te besteden aan het meten van merkkeuze-involvement met de semantische differentiaal. Wij geven er de voorkeur aan gebruik te maken van de Likert-schaal.

Voor een uitgebreid overzicht van de resultaten van de factoranalyse per produkt wordt verwezen naar Bijlage 8.

Een in de literatuur aangetroffen waarschuwing voor het gebruik van een semantische differentiaal voor het meten van involvement met betrekking tot de merkkeuze kan door ons worden ondersteund. McQuarrie en Munson (1987) stellen namelijk nadrukkelijk dat de semantische differentiaal van Zaichowsky (1985) ontwikkeld is voor het meten van involvement met betrekking tot produkten; deze kan niet zonder meer gebruikt worden voor het meten van involvement met de merkkeuze, zoals door ons, op aanraden van Zaichowsky, is gedaan.

\section{Deliberatie}

De items op de Likertschaal voor het meten van deliberatie ten aanzien van cassettebandjes, zijn aan dezelfde criteria ter verwijdering onderworpen als de items op de andere twee Likert-schalen (commitment en merkkeuze-involvement). Dat wil zeggen:

1 vaker dan 5 keer een respondent met weet niet/geen mening;

2 item-totaal correlatie lager dan .50 (Green et al. 1988);

3 geen verschil in gemiddelde per item voor wat betreft de score op dit item in het hoogste en laagste kwartiel (Green et al., 1988).

Vervolgens is ook hier nog een vierde criterium ter verwijdering toegepast (nadat elk van de items op de verschillende te construeren schalen (commitment, merkkeuze-involvement en elaboratie) aan de vorige criteria was onderworpen):

4 correlatie tussen items op verschillende schalen (commitment en merkkeuze-involvement én commitment en elaboratie) hoger dan .70 (Bijlage 6).

Alle zes items blijven behouden (Tabel 5.10). 
$1 \mathrm{Na}$ de aankoop van een frisdrank, praat ik nog vaak over het door mij gekochte merk met familie, vrienden of bekenden.

$2 \mathrm{Na}$ de aankoop van een frisdrank, heb ik verschillende advertenties over frisdrank bekeken.

$3 \mathrm{Na}$ de aankoop van een frisdrank, heb ik het door mij gekochte merk vergeleken met andere merken.

$4 \mathrm{Na}$ de aankoop van een frisdrank, heb ik nog vaak gedacht over de voor- en nadelen van de door mij gemaakte keuze.

$5 \mathrm{Na}$ de aankoop van een frisdrank heb ik nog verschillende produktevaluaties in bijv. de Consumentengids bekeken.

$6 \mathrm{Na}$ de aankoop van een frisdrank, heb ik de positieve en de negatieve aspecten van mijn keuze nog eens op de rij gezet.

*: frisdrank als produkt kan door elk ander produkt worden vervangen

Echter, bij jeans blijkt item 5 niet relevant. Gezien het feit dat jeans niet beoordeeld wordt in de Consumentengids, is dit wel begrijpelijk. De betrouwbaarheid van de schaal, gemeten met Cronbach-alpha, wordt voor de verschillende produkten weergegeven in Tabel 5.11. De item-totaalcorrelaties worden weergegeven in Tabel 5.12.

Tabel 5.11: Overzicht Cronbach-alpha deliberatie zoals gemeten bij de drie produkten (6 geselecteerde items).

\begin{tabular}{lll}
\hline & Cronbach-alpha & $\mathrm{n}$ \\
\hline cassette & .83 & 88 \\
jeans & .79 & 87 \\
frisdrank & .84 & 126 \\
\hline
\end{tabular}

$\mathrm{n}$ : aantal respondenten in de analyse

Tabel 5.12: Overzicht item-totaal correlatie elaboratie zoals gemeten bij de drie produkten (6 geselecteerde items).

\begin{tabular}{llll}
\hline Item & Cassettebandjes & Jeans & Frisdrank \\
\hline 1 & .59 & .63 & .46 \\
2 & .61 & .49 & .61 \\
3 & .60 & .53 & .58 \\
4 & .63 & .55 & .31 \\
5 & .63 & .44 & .50 \\
6 & .65 & .60 & .55 \\
\hline
\end{tabular}

Vastgesteld kan worden dat de items gezamenlijk een redelijk betrouwbare maat vormen voor het meten van deliberatie (Tabachnick en Fidell, 1989). Er wordt in het vervolg dan ook vanuit gegaan dat deliberatie kan worden gemeten als een simpele lineaire combinatie van de individuele items (Comrey, 1973).

Samengevat kan geconcludeerd worden dat commitment, merkkeuze-involvement en deliberatie betrouwbaar gemeten kunnen worden met de geconstrueerde schalen, met name gelet op de interne consistentie, de item totaal correlaties, de correlaties tussen de 
items van verschillende schalen en de resultaten van de factoranalyse (Likertschaal merkkeuze-involvement). $\mathrm{Nu}$ rest de vraag of deze schalen ook valide zijn.

\subsubsection{Validiteit van de schalen}

De 'content' validiteit van de schalen kan niet statistisch worden vastgesteld. Het feit dat betrouwbare en gevalideerde Engelse schalen als uitgangspunt zijn genomen, dat gebruik is gemaakt van een representatief aantal items en dat voor een in de literatuur aanvaarde methode van schaalconstructie is gekozen (Nunnally, 1978), stelt ons in staat te concluderen dat aan de eisen van 'content' validiteit van de verschillende schalen, in voldoende mate is beantwoord.

De 'convergente' validiteit van de schalen, een vorm van construct validiteit, kan worden bestudeerd door na te gaan of concepten samenhangen met andere concepten zoals verwacht mag worden dat zij samenhangen. Zo mag op grond van de literatuur verondersteld worden (Zaichowsky, 1985; Kapferer en Laurent, 1986 en Mittal en Lee, 1988) dat er een positieve relatie bestaat tussen merkkeuze-involvement en commitment. Tabel 5.13 geeft een overzicht van de verschillende correlatie-coëfficiënten.

Tabel 5.13: Correlaties tussen merkkeuze-involvement en commitment

\begin{tabular}{lll}
\hline & $\mathrm{r}$ & $\mathrm{n}$ \\
\hline cassettebandjes & $.61^{* *}$ & 44 \\
jeans & $.79^{* *}$ & 24 \\
frisdrank & .25 & 73 \\
\hline
\end{tabular}

**: p<.001; r: Pearson correlatie; n: aantal respondenten in de analyse

Er kan geconcludeerd worden dat er een positieve relatie tussen merkkeuze-involvement en commitment bestaat voor zover het cassettebandjes en jeans betreft. Met andere woorden: er is hier sprake van convergente validiteit. Dat er geen duidelijke positieve relatie tussen merkkeuze-involvement en commitment wordt gevonden bij frisdrank, heeft wellicht alles te maken met het feit dat frisdrank een produkt is, waarbij de merkkeuze-involvement en commitment over het algemeen laag zijn (hier zal dus rekening mee moeten worden gehouden bij de keuze van de produkten in het hoofdonderzoek).

De discriminante validiteit, ook een vorm van construct validiteit, kan worden vastgesteld met behulp van factoranalyse. Via factoranalyse kan worden nagegaan of commitment, merkkeuze-involvement en deliberatie van elkaar onafhankelijke concepten zijn. Alle geselecteerde items van de commitment, de involvment en de deliberatieschalen zijn hiertoe in één analyse opgenomen. De resultaten worden per produkt uitgebreid weergegeven in Bijlage 9. Tabel 5.14 geeft een samenvattend overzicht van de resultaten. 
Tabel 5.14: Samenvattend overzicht van de factoranalyse waarin alle items van de drie schalen zijn opgenomen.

\begin{tabular}{llcl}
\hline Factor & Eigenwaarde & Perc Var* & Cum Perc** \\
\hline Cassettebandjes & & & \\
1 & 9.00 & 39.1 & 39.1 \\
2 & 3.35 & 14.5 & 53.7 \\
3 & 1.49 & 6.5 & 60.2 \\
Jeans & & & \\
1 & 9.62 & 41.8 & 41.8 \\
2 & 2.86 & 12.4 & 54.3 \\
3 & 1.79 & 7.8 & 62.0 \\
Frisdrank & & & \\
1 & 7.05 & 30.7 & 30.7 \\
2 & 3.61 & 15.7 & 46.4 \\
3 & 2.08 & 9.1 & 55.4 \\
\hline
\end{tabular}

*: percentage verklaarde variantie; **: cumulatief percentage verklaarde variantie

Op basis van Tabel 5.14 en Bijlage 9 kan geconcludeerd worden dat merkkeuze-involvement, commitment en deliberatie duidelijk van elkaar te onderscheiden concepten zijn. Bij elk van de drie produkten kunnen drie factoren worden onderscheiden met elk een eigenwaarde groter dan één. Maar belangrijker nog: alle items van elke schaal afzonderlijk laden voornamelijk steeds het hoogst op één van deze drie factoren.

Ook de resultaten van de correlatie-analyse over alle items (Bijlage 6) van elk van de drie schalen, waarbij geen item hoger dan .70 met een item van een andere schaal blijkt te correleren, is een ondersteuning voor conclusie dat de afzonderlijke schalen over voldoende construct validiteit beschikken.

\subsubsection{Conclusie}

Dit hoofdstuk kan worden afgesloten met de conclusie dat via het vooronderzoek voldoende betrouwbare en valide schalen zijn ontwikkeld voor het meten van commitment, merkkeuze-involvement en deliberatie in het hoofdonderzoek.

Uiteraard zal tijdens het hoofdonderzoek opnieuw aandacht aan de betrouwbaarheid en validiteit van de schalen worden geschonken. De reden hiervoor is dat het hoofdonderzoek een andere populatie en, voor een deel, andere produkten betreft. 


\section{Opzet van het hoofdonderzoek en het profiel van de steekproef}

\subsection{Doelstelling}

De algemene doelstelling van het hoofdonderzoek is gericht op het verkrijgen van inzicht in de verklaring van ware merktrouw en de specifieke rol van manifeste tevredenheid daarbij. De in hoofdstuk 3 geformuleerde onderzoekshypothesen zullen in het hoofdonderzoek worden getoetst.

\section{2}

Vragenlijst

Het hoofdonderzoek is uitgevoerd met behulp van een schriftelijke vragenlijst. Deze schriftelijke vragenlijst is samengesteld naar aanleiding van de resultaten uit het vooronderzoek. De uiteindelijke vragenlijst is opgenomen in Bijlage 10. Onbespeelde cassettebandjes en haarshampoo zijn de produkten die in het onderzoek centraal staan.

\subsubsection{Verantwoording en beschrijving van de vragenlijst}

In het vooronderzoek zijn schalen ten behoeve van het meten van commitment, merkkeuze-involvement en deliberatie getest. Deze geteste schalen worden in het hoofdonderzoek opgenomen. Er is ervaring opgedaan met het meten van tevredenheid en merktrouw. Tevredenheid wordt in het hoofdonderzoek op dezelfde manier gemeten als in het vooronderzoek. Merktrouw wordt uitgebreider gemeten dan in het vooronderzoek om een nog beter inzicht te krijgen in de verschillende aspecten ervan. Daarnaast zijn aan de vragenlijst voor het hoofdonderzoek enkele vragen toegevoegd die in beperkte mate inzicht moeten geven in de rol van prijs(-elasticiteiten), distributie(-elasticiteiten) en gebruikssituaties bij de verklaring van merktrouw. Tot slot zijn een aantal achtergrondvariabelen opgenomen in de vragenlijst.

De schriftelijke vragenlijst bestaat uit twee delen. Deel eén heeft betrekking op onbespeelde cassettebandjes en deel twee op haarshampoo.

Onbespeelde cassettebandjes zijn als produkt gekozen omdat er in het vooronderzoek reeds goede ervaringen mee zijn opgedaan. Haarshampoo is gekozen op basis van enkele expert-interviews. Het streven was twee produkten te kiezen die frequent worden gekocht door vrijwel de gehele bevolking en die verschillen (naar onze verwachting) voor de gemiddelde niveaus van zowel de onafhankelijke als de afhankelijke variabelen in het onderzoeksmodel.

Naar verwachting is de gemiddelde mate van commitment, merkkeuze-involvement en deliberatie groter bij cassettebandjes dan bij haarshampoo. Ten aanzien van tevredenheid 
kan moeilijk vooraf een verschil tussen beide produkten worden verondersteld. In het algemeen wordt verwacht, dat de merktrouw bij cassettebandjes groter zal zijn dan bij haarshampoo.

Naast de genoemde zijn er nog een groot aantal andere verschillen te constateren tussen cassettebandjes en haarshampoo.

Haarshampoo is een produkt waarvan verwacht mag worden dat emotie een grote rol speelt bij de merkkeuze terwijl dit bij cassettebandjes minder het geval is. Dat emotie bij haarshampoo een grotere rol speelt blijkt ook uit de manier waarop voor beide produkten reclame wordt gemaakt. Bij haarshampoo staan meer emotionele aspecten centraal terwijl bij cassettebandjes vaak meer de nadruk ligt op technische specificaties. Daarnaast is bij haarshampoo het aantal produkt-introducties vele malen groter dan bij cassettebandjes. Bovendien is het aantal distributiepunten voor haarshampoo groter dan voor cassettebandjes. Van zeer jong tot erg oud maakt iedere Nederlander, in meer of mindere mate, regelmatig gebruik van haarshampoo. Haarshampoo is te rangschikken in de categorie produkten voor de persoonlijke verzorging.

Cassettebandjes worden vaker op grond van de technische specificatie gekocht dan haarshampoo, hoewel de verschillen in technische specificaties en fysieke kenmerken bij cassettebandjes moeilijk waarneembaar zijn. Cassettebandjes zijn, in vergelijking met haarshampoo, duurzamere goederen. De prijsrange (verschil tussen goedkoopste en duurste) is bij cassettebandjes smaller dan bij haarshampoo. Cassettebandjes vallen in de categorie audio-visuele produkten.

Voor beide produkten wordt in de vragenlijst eerst geïnventariseerd of deze de laatste zes (cassettebandjes) respectievelijk drie (haarshampoo) maanden zijn gekocht. Zo ja, dan wordt verzocht de overige vragen van dit deel te beantwoorden. Zo nee, dan wordt verzocht dit deel over te slaan.

De overige vragen in de vragenlijst hebben betrekking op merktrouw, tevredenheid, commitment, merkkeuze-involvement, deliberatie, gebruikssituatie, prijs en distributie.

Merktrouw wordt direct gemeten met behulp van vier vragen. Elk daarvan heeft betrekking op een andere operationalisatie van het begrip. (Vraagnummers zoals in de vragenlijst (Bijlage 10)).

Vraag 7 meet de kans dat - wanneer in de toekomst het produkt opnieuw wordt gekocht - hetzelfde merk gekocht wordt als bij de meest recente aankoop: kans op een herhalingsaankoop.

Vraag 9 meet de manier van heraankopen. Wordt steeds opnieuw hetzelfde merk gekocht of wordt af te toe of voortdurend van merk veranderd. (Op grond van deze twee vragen is het onmogelijk een onderscheid te maken tussen herhalingsaankopen en ware merktrouw.)

Vraag $10 \mathrm{f}$ meet de mate van ware merktrouw, variërend van een automatische herhalingsaankoop tot weloverwogen keuze of ware merktrouw. Vraag $10 \mathrm{f}$ is een samengestelde maat. Voor het vaststellen van de mate van ware merktrouw zijn niet de verschil-

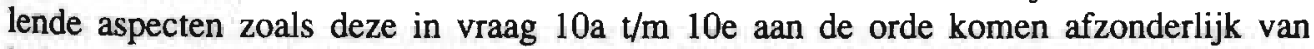
belang. Het is de interactie tussen deze afzonderlijke aspecten die centraal staat bij het meten van de mate van ware merktrouw. Ook in dit geval is het geheel 'meer' (anders) dan de som der delen. 
Vraag 35 meet of, en zo ja welke, andere merken in overweging worden genomen wanneer het produkt opnieuw wordt gekocht: de samenstelling van de evoked set. (Op grond van deze vraag is het eveneens onmogelijk een onderscheid te maken tussen herhalingsaankopen en ware merktrouw.)

De vraag aangaande de mate van ware merktrouw sluit het goed aan bij de theorie ten aanzien van merktrouw zoals deze in hoofdstuk 3 is geformuleerd.

De vraag naar de manier van heraankopen is opgenomen om als een sluis te fungeren naar de vraag over de mate van merktrouw. Respondenten die te kennen geven voortdurend van merk te wisselen kunnen, ons inziens, geen zinvolle informatie ten aanzien van hun mate van ware merktrouw verschaffen.

De vraag naar de kans op een herhalingsaankoop is opgenomen om feitelijke merktrouw in het algemeen te operationaliseren zonder een direct onderscheid te maken tussen ware merktrouw en herhalingsaankopen en met name om een altematieve operationalisatie van ware merktrouw mogelijk te maken, door deze kans op een herhalingsaankoop te combineren met de mate van commitment (een gecombineerde maat voor het meten van ware merktrouw).

De vraag naar de samenstelling van de evoked set moet eveneens gezien worden als een alternatieve operationalisatie van feitelijke merktrouw in het algemeen.

In ons onderzoek staat ware merktrouw centraal, aanvankelijk geoperationaliseerd als de mate van ware merktrouw en later geoperationaliseerd als loyaliteit.

Tevredenheid wordt gemeten met behulp van de vragen 4, 5 en 6 .

Allereerst wordt gevraagd een onderscheid te maken tussen tevredenheid of ontevredenheid met het gekochte merk. Vervolgens wordt met een zevenpuntsschaal en het aangeven van een percentage de mate van (on)tevredenheid gemeten.

Het onderscheid tussen tevredenheid en ontevredenheid moet worden gemaakt omdat tevredenheid en ontevredenheid door ons niet als twee uiteinden van één continuüm worden beschouwd (zie paragraaf 2.6.2), maar ieder voor zich op twee verschillende continua moeten worden geplaatst.

Commitment wordt gemeten met behulp van een Likertschaal die is opgebouwd uit de vragen 12, 14, 20, 23, 25 en 31 (afkomstig uit het vooronderzoek; overeenkomstig Tabel 5.1).

Merkkeuze-involvement wordt gemeten met behulp van een Likertschaal die is opgebouwd uit de vragen $11,15,16,17,19,21,22,26,27,30$ en 33 (afkomstig uit het vooronderzoek; overeenkomstig Tabel 5.4).

Deliberatie wordt gemeten met behulp van een Likertschaal die is opgebouwd uit de vragen 13, 18, 24, 28, 29 en 32 (afkomstig uit het vooronderzoek; overeenkomstig Tabel 5.10).

Tot slot meet vraag 3 de gebruikssituaties van het produkt en kan bij vraag 8 een reden worden gegeven voor de kans dat hetzelfde merk wordt gekocht als bij de meest recente aankoop. Vraag 36 inventariseert elasticiteiten ten aanzien van distributie en prijs. 
De achtergrondvariabelen worden aan het einde van de vragenlijst gemeten in het onderdeel 'algemene gegevens'. Achtereenvolgens zijn de algemeen gehanteerde variabelen als geslacht, leeftijd, beroep, grootte van het huishouden en inkomen in het onderzoek opgenomen.

Tevredenheid en commitment staan als verklarende variabelen van ware merktrouw in dit onderzoek centraal. Merkkeuze-involvement en deliberatie worden gebruikt als indicatoren voor de mate van elaboratie van de respondent op basis waarvan twee verschillende soorten tevredenheid kunnen worden onderscheiden: manifeste tevredenheid en latente tevredenheid. (Aan de gebruikssituatie, de reden, de distributie, de prijs en de achtergrondvariabelen zal in dit onderzoek (deze rapportage) niet nadrukkelijk aandacht worden besteed.)

\subsection{Steekproef}

Voor het werven van respondenten is gebruik gemaakt van advertenties in diverse media (Bijlage 11). Door 1078 personen is op de advertenties gereageerd. Aan al deze personen is de vragenlijst toegezonden. Er zijn uiteindelijk $861(79,9 \%)$ vragenlijsten geretourneerd. Hiervan zijn 838 vragenlijsten voor de sluitingsdatum (15 april 1992) binnen gekomen en in de analyse (77,7\%) opgenomen.

Per produkt verschilt het aantal respondenten aangezien niet iedere respondent de afgelopen periode een cassettebandje of haarshampoo heeft gekocht (Tabel 6.1).

In de begeleidende brief bij de vragenlijst is de respondenten verzocht er voor te zorgen dat het deel over cassettebandjes en het deel over haarshampoo wordt ingevuld door diegene in het huishouden, die beslist welk merk wordt gekocht. Hierdoor is het mogelijk dat de twee delen van de vragenlijst door verschillende respondenten zijn ingevuld. Hoewel er een grote overlap is tussen de steekproef voor cassettebandjes en de steekproef voor haarshampoo, zijn beide steekproeven niet identiek.

Tabel 6.1: De in de analyse opgenomen aantallen vragenlijsten (n)

n cassettebandjes: $\quad 589$

(laatste 6 maanden een cassettebandje gekocht)

n haarshampoo:

809

(laatste 3 maanden haarshampoo gekocht)

n totaal:

838

De frequentie-verdelingen van de achtergrondkenmerken van de respondenten zijn, voor beide produkten, opgenomen worden onderstaand gepresenteerd en zijn tevens opgenomen in Tabel 6.2 . 
Tabel 6.2: Overzicht achtergrondvariabelen cassettebandjes en haarshampoo (in procententen van het aantal respondenten per produkt)

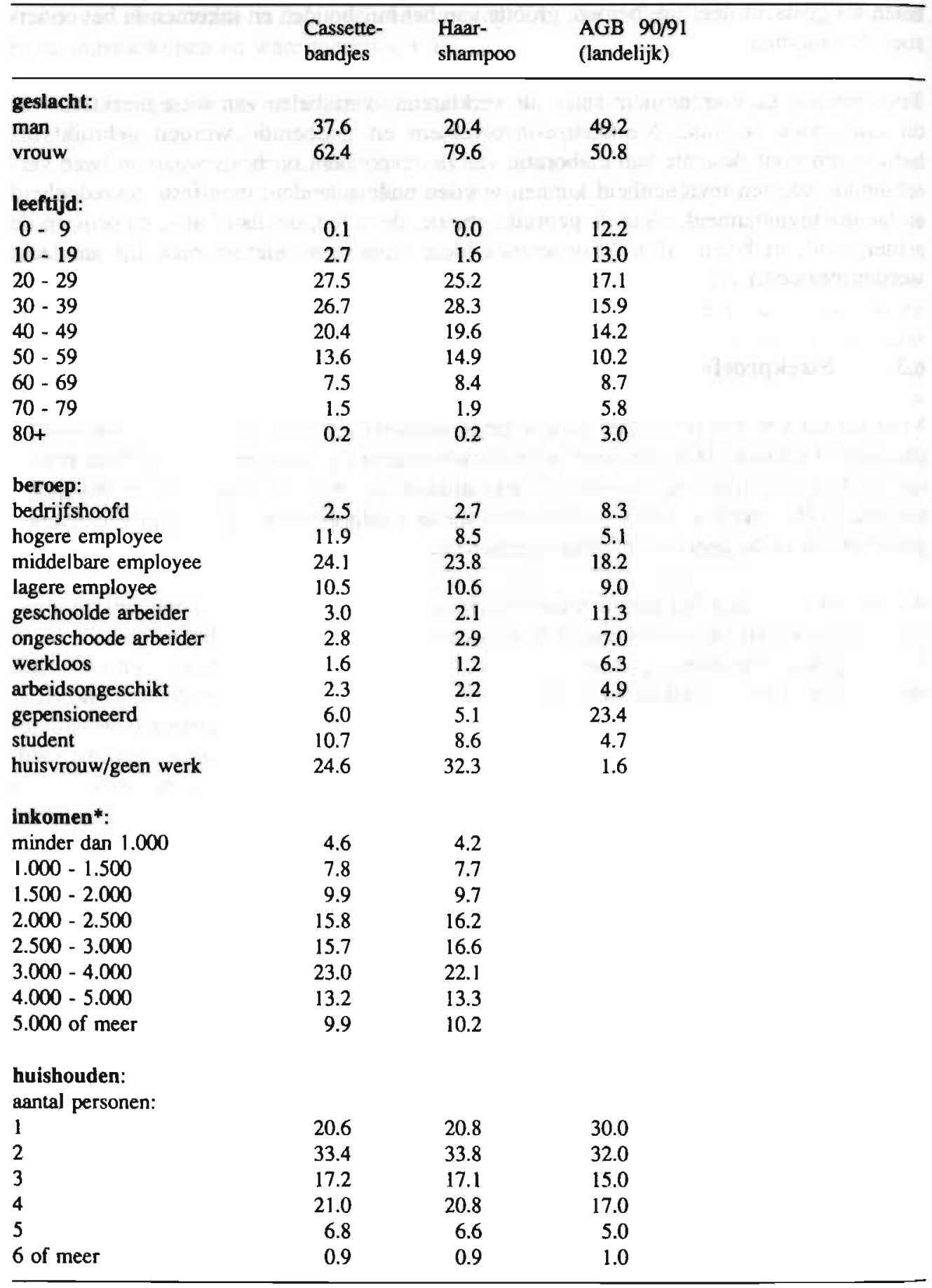

*: landelijke gegevens ontbreken 


\subsubsection{Cassettebandjes}

Het eerste deel van de vragenlijst, over cassettebandjes, is ingevuld door 293 mannen en 487 vrouwen. Van 58 respondenten is het geslacht onbekend. De leeftijd van de respondenten varieert van 18 tot 82 jaar (gemiddeld 39 jaar). De meeste respondenten zijn middelbaar employée of huisvrouw/man. Eén-derde van de respondenten leeft in een twee-persoonshuishouden. Gemiddeld ligt het netto inkomen van het huishouden tussen de 2500 tot 3000 gulden per maand (zie tevens Tabel 6.2).

\subsubsection{Haarshampoo}

Het tweede onderdeel, met betrekking tot haarshampoo is ingevuld door 162 mannen en 634 vrouwen. In dit geval is van 42 respondenten het geslacht onbekend. De leeftijd ligt eveneens tussen de 18 en 82 jaar (gemiddeld 40 jaar). Net als bij cassettebandjes zijn de meeste respondenten middelbaar employée of huisvrouw/man. Eén-derde van de respondenten leeft wederom in een twee-persoonshuishouden en tevens ligt het gemiddelde netto inkomen van het huishouden ook hier tussen de 2500 tot 3000 gulden per maand (zie tevens Tabel 6.2).

\subsubsection{Vergelijking tussen cassettebandjes en haarshampoo}

In de eerste plaats moet worden geconstateerd dat de vragenlijst in het algemeen vaker door vrouwen dan door mannen is ingevuld. De vragenlijst over haarshampoo is relatief vaker door vrouwen ingevuld dan de vragenlijst over cassettebandjes (percentage vrouwen bedraagt bijna $80 \%$ bij haarshampoo en ruim $62 \%$ bij cassettebandjes). Hierin komt ook tot uiting dat - zoals ook de bedoeling was - vooral de beslissers de vragenlijst invullen: dat is veelal de vrouw. Uiteraard bestaat er een grote overeenkomst tussen de achtergrondvariabelen aangezien beide steekproeven elkaar voor een groot deel overlappen.

\subsection{Verantwoording en representativiteit van de steekproef}

\subsubsection{Verantwoording van de steekproef}

Ten behoeve van het verkrijgen van respondenten voor het invullen van de vragenlijsten is gebruik gemaakt van advertenties in diverse media. Dit leek de meest aangewezen weg, op een efficiënte en effectieve manier respondenten te werven. Een afdruk van de schriftelijke advertentie is opgenomen in Bijlage 11.1. Deze advertentie is tezamen met een artikel (zie Bijlage 11.2) verschenen in 'De Limburger' van 26 februari 1992. De advertentie is tezamen met een artikel 'van eigen hand' (zie Bijlage 11.3) verschenen in 'De Trompetter van 11 maart 1992. Verder is dit artikel ook geplaatst in 'De Trompetter' van 26 maart, 'De Maaspost' van 4 maart en 11 maart. De advertentie is op 21 maart ook geplaatst in 'De Telegraaf' en in het april nummer van 'HBO Job News'. Op 8 maart 1992 is tijdens een uitzending van de RTV-studio in Melick-Herkenbosch aandacht besteed aan het onderzoek, evenals op 12 maart tijdens een uitzending van 
Omroep Limburg in het consumentenprogramma 'Voor gebruik schudden'. Tijdens beide uitzendingen is een oproep gedaan aan de luisteraars om aan een onderzoek naar koopgedrag mee te werken.

In totaal zijn 1078 reacties binnen gekomen van personen die te kennen gaven aan het onderzoek te willen meewerken (zie Tabel 6.3). Aan al deze personen is de vragenlijst met begeleidende brief en een portvrije retourenvelop toegezonden.

Tabel 6.3: Overzicht aangevraagde en binnengekomen enquêtes

\begin{tabular}{|c|c|c|c|c|c|c|c|}
\hline $\begin{array}{l}\text { Datum } \\
\text { enquetes } \\
\text { binnen }\end{array}$ & $\begin{array}{l}\text { Aantal } \\
\text { enquetes } \\
\text { binnen }\end{array}$ & Krant & $\begin{array}{l}\text { Datum } \\
\text { enquetes } \\
\text { sangevraagd }\end{array}$ & $\begin{array}{l}\text { Aantal } \\
\text { enquetes } \\
\text { angevrangd }\end{array}$ & $\begin{array}{l}\text { Totaal } \\
\text { anngerrangd } \\
\text { (cumulatie) }\end{array}$ & $\begin{array}{l}\text { Aangerraggd } \\
\text { per bon }\end{array}$ & $\begin{array}{l}\text { Aangevragad } \\
\text { per } \\
\text { telefoon }\end{array}$ \\
\hline $05 / 03$ & $001-031$ & Limburger & 26102 & 132 & 132 & 095 & 037 \\
\hline $06 / 03$ & $032-053$ & 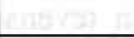 & $27 / 02$ & 066 & 198 & 035 & 031 \\
\hline $10 / 03$ & $054-065$ & 18 & $28 / 02$ & 003 & 201 & $15+12=$ & 003 \\
\hline $11 / 03$ & $066-143$ & Maaspost & $04 / 03$ & 071 & 272 & 071 & . \\
\hline $12 / 03$ & $144-145$ & & $05 / 03$ & 029 & 301 & 013 & 016 \\
\hline $13 / 03$ & $146-161$ & 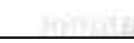 & $06 / 03$ & 011 & 312 & 005 & 006 \\
\hline $16 / 03$ & $162-163$ & & $10 / 03$ & Dos & 317 & 005 & \\
\hline $17 / 03$ & $164-17 \mid$ & Trompetter & $11 / 03$ & 005 & 322 & 004 & 001 \\
\hline $18 / 03$ & $172-283$ & Radio & $12 / 03$ & 071 & 393 & 023 & 048 \\
\hline $19 / 03$ & $284-285$ & 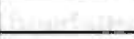 & $13 / 03$ & 071 & 464 & 051 & 020 \\
\hline $20 / 03$ & 286.295 & & $18 / 03$ & 123 & 587 & 123 & \\
\hline $23 / 03$ & 296-316 & & $20 / 03$ & 003 & 590 & $\infty 03$ & \\
\hline $24 / 03$ & $317-393$ & Telegraaf & $21 / 03$ & 061 & 651 & & 061 \\
\hline $26 / 03$ & $394-414$ & & $23 / 03$ & 012 & 663 & 004 & 008 \\
\hline $27 / 03$ & $415-429$ & & $24 / 03$ & 103 & 766 & 095 & 008 \\
\hline $30 / 03$ & $430-438$ & Trompelter & $25 / 03$ & & & & \\
\hline $31 / 03$ & $439-546$ & Vacature & $26 / 03$ & 140 & 906 & 127 & 013 \\
\hline $01 / 04$ & $547-634$ & & $27 / 03$ & 072 & 978 & 072 & \\
\hline $03 / 04$ & $635-692$ & & $30 / 03$ & 028 & 1006 & 023 & 005 \\
\hline $07 / 04$ & $693-760$ & & $31 / 03$ & 035 & 1041 & 035 & \\
\hline $09 / 04$ & $76 i-784$ & & $01 / 04$ & 010 & 1051 & 010 & \\
\hline $10 / 04$ & $785-802$ & & $02 / 04$ & 009 & 1060 & $\infty 09$ & \\
\hline $13 / 04$ & $803-806$ & & $03 / 04$ & 007 & 1067 & 007 & \\
\hline $14 / 04$ & $807-833$ & & $09 / 04$ & 005 & 1072 & 005 & \\
\hline $15 / 04$ & $834-838$ & & $13 / 04$ & $\infty 03$ & 1075 & $\infty 03$ & \\
\hline $16 / 04$ & $839-843$ & & $14 / 04$ & 003 & 1078 & 003 & \\
\hline $21 / 04$ & $844-857^{*}$ & & & & & & \\
\hline nelto & 838 & $\begin{array}{c}\text { binnen } \\
\text { gekomen }\end{array}$ & & & totaal 1078 & & \\
\hline
\end{tabular}

* na 21/4 zijn in totaal 4 vragenlijsten geretourneerd, waardoor het bruto totaal komt op 861 . 
Achthonderdéénenzestig vragenlijsten zijn geretourneerd (79,9\%; zie Tabel 6.3). Achthonderachtendertig vragenlijsten konden worden opgenomen in de analyse $(77,7 \%)$. De overige vragenlijsten (23) zijn na de sluitingsdatum binnen gekomen. Er zijn geen vragenlijsten onbruikbaar bevonden.

In verband met het verzoek in de begeleidende brief om het deel met betrekking tot cassettebandjes en het deel met betrekking tot haarshampoo in te laten vullen door diegene in het huishouden die beslist welk merk wordt gekocht, is het mogelijk dat deze twee delen niet door dezelfde respondent zijn ingevuld.

Het feitelijke aantal respondenten dat heeft meegewerkt aan het onderzoek is hierdoor groter dan het aantal vragenlijsten dat is geretourneerd.

Het responsepercentage dient echter te worden vastgesteld op basis van het aantal verstuurde en het aantal geretourneerde vragenlijsten: $79,9 \%$.

Het responsepercentage is, naar verwachting, zo hoog omdat respondenten vooraf duidelijk te kennen hebben gegeven te willen meewerken aan het onderzoek.

\subsubsection{Representativiteit van de steekproef}

Voor het onderzoek is geen landelijk representatieve steekproef getrokken. Dit is ook niet nodig gezien aard en doelstelling van het onderzoek. Het onderzoek is er namelijk op gericht om - in exploratieve zin - inzicht te verkrijgen in de relatie tussen merktrouw en tevredenheid. Het gaat er met name om individuele en groepen consumenten te traceren die variëren in de mate van tevredenheid. Vervolgens wordt hun merktrouw geanalyseerd. Het is niet de bedoeling een landelijk representatief beeld te geven van de omvang van deze processen; het gaat om het weergeven van de aard en de kenmerken van zo'n proces. Daarbij is gestreefd naar zoveel mogelijk waarnemingen om het proces zo gedetailleerd mogelijk te kunnen weergeven.

Hiemaast kan nog het volgende gesteld worden ten aanzien van de representativiteit van de steekproef. Respondenten uit Limburg zijn in de steekproef oververtegenwoordigd. Geschat op basis van de aanmeldingen is ongeveer de helft van de respondenten afkomstig uit Limburg. Het niet representatief zijn van de steekproef ten aanzien van dit demografische kenmerk van de respondenten is, gezien de doelstellingen van het onderzoek, geen reden tot ongerustheid. Er is namelijk geen enkele goede reden om a priori te veronderstellen dat Limburgers meer/minder tevreden of merktrouw zijn dan inwoners uit andere provincies in Nederland bij deze (niet regio-gebonden) produkten. Bovendien was uit de advertentie niet af te leiden dat het om een onderzoek naar merktrouw en tevredenheid ging; alleen koopgedrag wordt genoemd.

Een vertekening van de representativiteit van de steekproef kan zijn opgetreden doordat de respondenten duidelijk zelf te kennen hebben gegeven aan het onderzoek te willen meewerken (zelf-selectie-bias). Mogelijk wordt hierdoor bij de respondenten een hoger niveau van merkkeuze-involvement gevonden. Dit is echter moeilijk na te gaan.

Gegeven het feit dat het hier een eerste onderzoek naar de relatie tussen tevredenheid en merktrouw betreft, maakt dat ten aanzien van de representativiteit van het onderzoek een aantal concessies kunnen worden gedaan. Op dit moment is niet het absolute niveau van merkkeuze-involvement, commitment en andere relevante variabelen van centraal be- 
lang. Het gaat om het relatieve belang van de verschillende concepten bij de verklaring van de relatie tussen tevredenheid en merktrouw bij verschillende groepen consumenten.

\subsection{2a Representativiteit ten opzichte van de achtergrondkenmerken}

De beoordeling van de representativiteit van de steekproef op basis van de achtergrondkenmerken kan gemaakt worden door de frequentie verdelingen in onze steekproef qua leeftijd, beroep en grootte van het huishouden te vergelijken met de landelijke gegevens (AGB 1990; 1991). Zie tevens Tabel 6.2 voor de frequentie verdelingen achtergrondkenmerken. Uit de vergelijking van de gegevens uit de steekproef en de landelijke verdeling kan geconcludeerd worden dat onze steekproef voor wat betreft de achtergrondkenmerken redelijk goed representatief is.

\subsection{2b Representativiteit ten opzichte van 'marktaandelen' van de gekochte merken.}

Een andere manier om na te gaan of onze steekproef voldoende representatief is, is door een vergelijking te maken tussen de door ons geconstateerde marktaandelen van merken en de feitelijke marktaandelen van dezelfde merken. Deze vergelijking heeft plaatsgevonden. De feitelijke marktaandelen van de merken zijn helaas vertrouwelijk, zodat deze niet vermeld kunnen worden. Wel kan geconcludeerd worden dat onze steekproef ook wanneer een vergelijking wordt gemaakt tussen de marktaandelen in de steekproef en de feitelijke marktaandelen redelijk goed representatief is.

Samenvattend kan gesteld worden dat, gezien de doelstelling van ons onderzoek, de steekproef aan de gestelde verwachtingen en doelen beantwoordt. 


\section{Eerste resultaten van het empirisch onderzoek: merktrouw en de mate van tevredenheid}

\subsection{Resultaten: eerste bevindingen}

In dit hoofdstuk komen de eerste globale resultaten van het empirisch onderzoek aan de orde. Allereerst wordt een overzicht gegeven van de frequentieverdelingen van de antwoorden op de afzonderlijke vragen uit de vragenlijst. Doel ervan is een eerste indruk te krijgen van de verdeling van (ware) merktrouw en de mate van tevredenheid in de steekproef. De frequentieverdelingen van de antwoorden, voor twee produkten (onbespeelde cassettebandjes en haarshampoo) staan in Bijlage 10.

Vervolgens wordt met behulp van verschillende bivariate analyses de relatie tussen (ware) merktrouw en de mate van tevredenheid aan een inventariserend onderzoek onderworpen. Hierbij zal allereerst, met name door gebruik van kruistabellen, worden gelet op de soort verbanden (lineair of curvilineair). Hierdoor wordt een nader initieel inzicht verkregen in de samenenhang tussen de verschillende variabelen. Daarna worden de verbanden nader gekwantificeerd met behulp van correlatie-analyse. In dit hoofdstuk wordt nog geen aandacht besteed aan het onderscheid tussen manifeste- en latente tevredenheid. Wij concentreren ons nu nog slechts op de mate van tevredenheid. De soort tevredenheid (manifest of latent) komt in hoofdstuk 8 aan de orde. Dit betekent dat in dit hoofdstuk aandacht wordt besteed aan hypothese 1, (tussen de mate van tevredenheid en ware merktrouw bestaat geen directe relatie) hypothese 2 (tussen de mate van tevredenheid en commitment bestaat wel een directe relatie) en hypothese 5 (commitment leidt tot ware merktrouw). Hypothese 3 en hypothese 4, met betrekking tot manifeste tevredenheid, komen in het volgende hoofdstuk aan de orde.

Voor de aanvang van de bespreking van de resultaten wordt benadrukt dat wij spreken van merktrouw wanneer wordt gedoeld op het herhaald aankopen van een merk, waarbij niet duidelijk is of hieraan commitment bij het merk ten grondslag ligt. Aan ware merktrouw ligt (in tegenstelling tot herhalingsaankopen) echter wél commitment bij het merk ten grondslag. Het concept ware merktrouw wordt voorlopig geoperationaliseerd als 'de mate van ware merktrouw'. Daamaast is merkkeuze-involvement de indicator van de motivatie van de consument om de merkkeuze te evalueren en deliberatie is de indicator van de capaciteit van de consument om de merkkeuze te evalueren. Samen zullen beide indicatoren bepalend zijn voor de elaboratie van een consument over de merkkeuze en dus voor de soort tevredenheid. 


\subsubsection{Merktrouw en de mate van tevredenheid}

\section{Cassettebandjes}

Vijfhonderdnegenentachtig respondenten hebben in de afgelopen zes maanden tenminste één cassettebandje gekocht. (In het vervolg van deze paragraaf worden percentages berekend op basis van dit aantal.)

Drieënveertig procent van de respondenten geeft aan het cassettebandje niet voor een speciaal gebruik te hebben gekocht. Veertig procent ziet het opnemen van muziek als een speciaal gebruik van cassettebandjes. De overige zeventien procent heeft diverse andere vormen van speciaal gebruik; cassettebandjes cadeau geven $(6 \%)$ is dan de belangrijkste.

Vierennegentig procent van de respondenten geeft aan tevreden te zijn met het gekochte merk cassettebandje. Van deze tevreden respondenten is ruim één derde voor $100 \%$ tevreden. Een kwart is voor $75 \%$ of minder tevreden. Percentages onder de $40 \%$ tevredenheid komen niet voor.

Slechts twee procent van de respondenten geeft te kennen ontevreden te zijn met het laatst gekochte merk cassettebandje en vier procent van de respondenten weet niet of zij tevreden of ontevreden zijn met het merk.

Dertig procent van de respondenten zegt hetzelfde merk cassettebandje met $100 \%$ zekerheid opnieuw te zullen kopen wanneer in de toekomst opnieuw een cassettebandje wordt gekocht. Eveneens dertig procent van de respondenten is hier niet zo zeker van. Deze respondenten schatten de kans op hoogstens $50 \%$ dat zij hetzelfde merk opnieuw zullen kopen.

De belangrijkste redenen om een bepaald merk cassettebandje opnieuw te kopen, hangen samen met de kwaliteit, prijs/kwaliteit verhouding en tevredenheid.

Acht procent vermeldt voortdurend van merk te veranderen bij de aankoop van cassettebandjes. Achtendertig procent geeft aan steeds hetzelfde merk te kopen en de overige $54 \%$ verandert af en toe van merk.

Zevenenveertig procent van de respondenten herkent zich in de volgende beschrijving van het koopgedrag: men is indertijd min of meer toevallig met het merk van zijn/haar keuze in aanraking gekomen toen men voor het eerst dit merk kocht; het merk wordt automatisch weer gekocht, zonder er echt over na te denken en het is erg gemakkelijk om van merk te veranderen.

Vierendertig procent van de respondenten herkent zich meer in de volgende beschrijving: de respondent heeft bij de eerste aankoop indertijd heel bewust voor het merk gekozen; er is goed over de keuze nagedacht en het is belangrijk om steeds het betreffende merk te kopen; het is zeer moeilijk om de respondent van merk te doen veranderen.

De overige twintig procent herkent zich niet direct in én van beide posities; zij geven de voorkeur aan het midden. 
Vijftig procent van de respondenten neemt geen ander merk in overweging bij de eerstvolgende aankoop van een cassettebandje. Eénenvijftig procent koopt geen ander merk, wanneer het merk waar de voorkeur naar uitgaat, niet verkrijgbaar is in de winkel die wordt bezocht. Eén-derde koopt geen ander merk wanneer het merk waaraan de voorkeur wordt gegeven, fors in prijs is verhoogd en bijna de helft koopt geen ander merk wanneer een ander merk fors in prijs is verlaagd.

Samengevat is ruim negentig procent van de respondenten tevreden met het gekochte merk cassettebandje. Eén-derde van deze respondenten is zelfs voor $100 \%$ tevreden. Dertig procent van het totaal aantal respondenten is voor $100 \%$ zeker dat ze hetzelfde merk cassettebandje opnieuw te zullen kopen. Ruim één-derde van de respondenten vindt zijn/haar koopgedrag het best omschreven als een weloverwogen keuze of - in onze terminologie - ware merktrouw.

Er kan geconcludeerd worden dat er voldoende spreiding (variantie) in de data aanwezig is om, op zinvolle wijze, de relatie tussen de mate van tevredenheid en de mate van ware merktrouw nader te onderzoeken. De belangrijkste bevindingen tot nu toe worden samengevat in Schema 7.1.

\section{Haarshampoo}

Van alle respondenten hebben 809 de afgelopen drie maanden haarshampoo gekocht. (Percentages worden in het vervolg van deze paragraaf berekend op basis van dit aantal.)

Zesenveertig procent van deze respondenten heeft de haarshampoo niet voor een speciaal gebruik gekocht. Eénendertig procent heeft de shampoo gekocht vanwege de speciale verzorgende eigenschappen van de shampoo (volume, anti-roos etc.) en achttien procent heeft als speciaal gebruik van de haarshampoo aangegeven: "het wassen van de haren". De overige 5\% noemt diverse andere soorten speciaal gebruik. Hieronder wordt onder meer verstaan: het cadeau geven en het wassen van kleding.

Zesennegentig procent is tevreden met het gekochte merk haarshampoo. Van deze tevreden respondenten is éen-derde $100 \%$ tevreden. Ruim een kwart is voor $75 \%$ of minder tevreden. Het percentage tevredenheid is soms heel laag en incidenteel $0 \%$.

Twee procent van de respondenten is ontevreden over het laatst gekochte merk haarshampoo. Eveneens twee procent geeft aan niet te weten of zij tevreden of ontevreden zijn met het merk haarshampoo.

Negenendertig procent van de respondenten geeft aan hetzelfde merk haarshampoo met $100 \%$ zekerheid weer opnieuw te zullen kopen. Zevenentwintig procent van de respondenten is daar niet zo zeker van. Deze respondenten schatten de kans op hoogstens 50\% dat zij hetzelfde merk haarshampoo opnieuw zullen kopen.

De belangrijkste redenen om een bepaald merk haarshampoo opnieuw te kopen, hangen samen met de prijs/kwaliteit verhouding en tevredenheid. 
Zeven procent vermeldt voortdurend van merk te veranderen bij de aankoop van haarshampoo. Tweeënveertig procent vermeldt steeds hetzelfde merk te kopen en de overige $51 \%$ verandert af en toe van merk.

Drieënveertig procent van de respondenten omschrijft hun koopgedrag als volgt: de respondent is indertijd min of meer toevallig met het merk van zijn/haar keuze in aanraking gekomen toen hij/zij voor het eerst dit merk haarshampoo kocht; het merk wordt automatisch weer gekocht, zonder er echt over na te denken en het is erg gemakkelijk om van merk te veranderen.

Tweeënveertig procent van de respondenten omschrijft hun koopgedrag meer als volgt: de respondent heeft bij de eerste aankoop indertijd heel bewust voor het merk gekozen; er is goed over de keuze nagedacht en het is belangrijk om steeds het betreffende merk te kopen; het is zeer moeilijk om de respondent van merk te doen veranderen.

De overige 15 procent geeft de voorkeur aan het midden tussen deze twee posities.

Door zestig procent van de respondenten wordt geen ander merk in overweging genomen bij de eerstvolgende aankoop van haarshampoo. Eénenzestig procent koopt geen ander merk wanneer het merk, waar de voorkeur naar uitgaat, niet verkrijgbaar is in de winkel die wordt bezocht. Vijfenveertig procent koopt geen ander merk, wanneer het merk waaraan de voorkeur wordt gegeven fors in prijs is verhoogd en vijfenzestig procent koopt geen ander merk wanneer een ander merk fors in prijs is verlaagd.

Samengevat blijkt dat ruim vijfennegentig procent van de respondenten tevreden is met het gekochte merk cassettebandje; eén-derde hiervan is zelfs voor $100 \%$ tevreden. Bijna veertig procent van het totaal aantal respondenten geeft aan voor $100 \%$ zeker te zijn hetzelfde merk cassettebandje opnieuw te zullen kopen. Ruim veertig procent van de respondenten vindt zijn/haar koopgedrag het best omschreven als een weloverwogen keuze of ware merktrouw.

Ook op basis van deze bevindingen kan worden vastgesteld dat er voldoende spreiding (variantie) in de data aanwezig is om de relatie tussen de mate van tevredenheid en de mate van ware merktrouw aan een nadere studie te onderwerpen. De belangrijkste bevindingen worden samengevat in Schema 7.1.

\subsubsection{Commitment, merkkeuze-involvement en deliberatie}

In de vragenlijst zijn 3 verschillende vijfpunts (Likert-)schalen opgenomen om deze concepten te kunnen meten, die verondersteld worden van invloed te zijn op de relatie tussen tevredenheid en merktrouw: een schaal voor het meten van commitment, een schaal voor het meten van merkkeuze-involvement en een schaal voor het meten van deliberatie. De commitment-schaal bestaat uit 6 , de merkkeuze-involvementschaal uit 11 en de deliberatieschaal eveneens uit 6 items (zie Tabel 5.1; Tabel 5.4 en Tabel 5.10).

Commitment en merkkeuze-involvement zijn concepten die theoretisch goed van elkaar zijn te onderscheiden (zie par 4.3). Echter, het meten ervan in empirisch onderzoek levert nog wel eens problemen op. De operationele definiëring van begrippen, in termen 
van de items waarmee de verschillende schalen zijn geconstrueerd, lijkt vaak sterk op elkaar. Om na te kunnen gaan of commitment, merkkeuze-involvement en deliberatie valide en betrouwbaar zijn gemeten in het hoofdonderzoek, is een aantal toetsen uitgevoerd. Deze toetsen bouwen uiteraard voort op de gegevens die reeds uit het vooronderzoek zijn verkregen over de betrouwbaarheid en de validiteit van de gebruikte schalen (paragraaf 5.4.2 en 5.4.3).

Om er zeker van te zijn dat elk item voldoende relevante informatie bevat, is allereerst wederom per item van elk van de drie schalen en over de twee produkten gesplitst, nagegaan of:

1 er meer dan $15 \%$ weet niet/geen mening voorkomt;

2 de item-totaalcorrelatie lager is dan .50;

3 er geen verschil in gemiddelde per item voor wat betreft de score op dit item in het hoogste en laagste kwartiel bestaat (Green et al., 1988).

Vervolgens is nog een vierde criterium ter verwijdering toegepast (nadat elk van de items op de verschillende te construeren schalen (commitment, merkkeuze-involvement en elaboratie) aan de vorige criteria was onderworpen):

4 correlatie tussen items op verschillende schalen (commitment en merkkeuze-involvement én commitment en elaboratie) hoger dan .70 (Bijlage 12).

Op geen enkel item wordt vaker dan $15 \%$ weet niet/geen mening gescoord. Voor geen enkel item is de item-totaalcorrelatie lager dan .50. Bij elk item is er een verschil in de gemiddelde score van het laagste en het hoogste kwartiel. Geen enkel item van de ene schaal correleert meer dan .70 met een item van een andere schaal. Dit betekent dat de gedeelde variantie van twee items maximaal $50 \%$ kan bedragen. Dit wordt acceptabel geacht omdat commitment en merkkeuze-involvement op theoretische gronden met elkaar samenhangen. Deze samenhang zal voor een deel ook in de schalen naar voren komen.

Op grond van de criteria en de verrichte analyses wordt besloten de schalen in hun oorspronkelijke vorm te handhaven.

Voorts is de betrouwbaarheid van elk van de drie schalen wederom bepaald met Cronbach-alpha (Peter, 1979). Cronbach-alpha geeft inzicht in de interne consistentie van de schaal (zie Tabel 7.1). 
Tabel 7.1: Overzicht Cronbach-alpha van commitment, merkkeuze-involvement en deliberatie bij cassettebandjes en haarshampoo

\begin{tabular}{lll}
\hline & Cronbach-alpha & $\mathrm{n}$ \\
\hline $\begin{array}{l}\text { commitment } \\
\text { cassettebandjes }\end{array}$ & .88 & 454 \\
haarshampoo & .89 & 648 \\
$\begin{array}{l}\text { merkkeuze-involvement } \\
\text { cassettebandjes }\end{array}$ & .91 & \\
haarshampoo & .91 & 405 \\
deliberatie & & 598 \\
cassettebandjes & .78 & \\
haarshampoo & .74 & 398 \\
\hline
\end{tabular}

Op basis van de hoogte van de Cronbach-alpha's blijkt dat de door ons ontwikkelde schalen voor het meten van commitment, merkkeuze-involvement en deliberatie over voldoende inteme consistentie beschikken. Hieruit mag worden afgeleid dat commitment, merkkeuze-involvement en deliberatie betrouwbaar kunnen worden gemeten.

Gegeven (1) de interne consistentie van elke schaal; (2) het feit dat elk item relevante informatie bevat en (3) het afwezig zijn van zeer hoge correlaties tussen items van de afzonderlijke schalen $(>.70)$, kan er terecht van de assumptie worden uitgegaan dat de drie concepten kunnen worden gemeten als een simpele lineaire combinatie van de individuele items (Comrey, 1973). Dit betekent dat somscores van de respondenten voor commitment, merkkeuze-involvement en deliberatie voor verdere analyse kunnen worden gebruikt.

$\mathrm{Nu}$ is aangetoond dat commitment, merkkeuze-involvement en deliberatie betrouwbaar kunnen worden gemeten met de desbetreffende schalen, dient aandacht te worden besteed aan de validiteit van de schalen in het hoofdonderzoek.

De 'content' validiteit van de schalen kan niet statistisch worden vastgesteld. Op grond van het feit dat betrouwbare en in het vooronderzoek valide bevonden schalen als uitgangspunt zijn genomen, moet worden geconcludeerd dat aan de eisen van 'content' validiteit van de verschillende schalen is beantwoord.

De 'convergent' validiteit van de schalen, een vorm van 'construct' validiteit, kan worden bestudeerd door na te gaan of de concepten samenhangen met andere concepten zoals mag worden verwacht. Op grond van de literatuur moet verondersteld worden (Zaichowsky, 1985; Kapferer en Laurent, 1986 en Mittal en Lee, 1988) dat er een duidelijke positieve relatie bestaat tussen enerzijds merkkeuze-involvement en commitment en dat er een enigszins positieve relatie bestaat tussen merkkeuze-involvement en deliberatie. Tabel $7.2 \mathrm{a} / \mathrm{b}$ geeft een overzicht van de correlatiecoëfficiënten tussen commitment, merkkeuze-involvement en deliberatie. 
Tabel 7.2a: Correlatie (Pearson corr) tussen commitment en merkkeuze-involvement en merkkeuzeinvolvement en deliberatie bij cassettebandjes

\section{Cassettebandjes}

commitment

1.0000

commitment

merkkeuze-involvement

deliberatie merkkeuze-

involvement

$.7492 * *$
1.0000 deliberatie

$.2624 * *$

$.4724^{* *}$

$\mathrm{n}=322 ; * *: \mathrm{p}<.001$

Tabel 7.2b: Correlatie (Pearson corr) tussen commitment en merkkeuze-involvement en merkkeuzeinvolvement en deliberatie bij haarshampoo

\section{Haarshampoo}

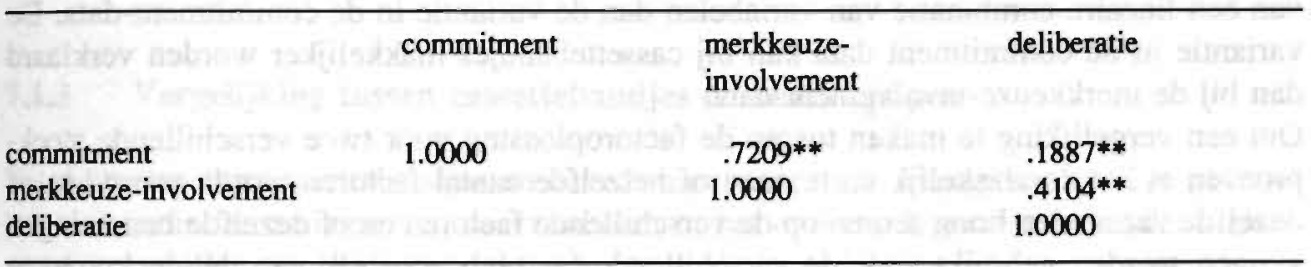

$\mathrm{n}=480 ; * * \mathrm{p}<.001$

Er kan geconcludeerd worden dat een duidelijke positieve relatie bestaat tussen merkkeuze-involvement en commitment. Tevens moet worden geconcludeerd dat een positieve relatie bestaat tussen merkkeuze-involvement en deliberatie. Dit betekent dat aan de eisen van 'convergent' validiteit van de schalen is voldaan.

De 'discriminant' validiteit, ook een vorm van 'construct' validiteit, kan worden vastgesteld door na te gaan of commitment, merkkeuze-involvement en deliberatie van elkaar onafhankelijke concepten zijn. Met behulp van factoranalyse, waarbij alle items in één keer worden opgenomen in de analyse, is dit na te gaan. Zijn commitment, merkkeuzeinvolvement en deliberatie van elkaar onafhankelijke concepten dan betekent dit dat zij elk door een eigen factor worden vertegenwoordigd. Tabel $7.3 \mathrm{a} / \mathrm{b}$ bevat in het kort de resultaten van de factoranalyse. De uitgebreide resultaten staan vermeld in Bijlage 13.

Tabel 7.3a: Factoranalyse alle items (PCA: varimax rotatie, max. 3 factoren) bij cassettebandjes

\section{Cassettebandjes}

\begin{tabular}{llll}
\hline Factor & Eigenwaarde & Perc Var & Cum Perc \\
1 & 9.15067 & 39.8 & 39.8 \\
2 & 2.54966 & 11.1 & 50.9 \\
3 & 1.18428 & 5.1 & 56.0 \\
\hline
\end{tabular}


Tabel 7.3b: Factoranalyse alle items (PCA: varimax rotatie, max. 3 factoren) bij haarshampoo

\section{Haarshampoo}

\begin{tabular}{llll}
\hline Factor & Eigenwaarde & Perc Var & Cum Perc \\
1 & & & \\
2 & 8.74798 & 38.0 & 38.0 \\
3 & 2.49338 & 10.8 & 48.9 \\
\hline
\end{tabular}

Uit de analyse blijkt dat commitment, merkkeuze-involvement en deliberatie elk door een afzonderlijke factor worden gerepresenteerd. Bij cassettebandjes blijkt commitment de belangrijkste factor te zijn en bij haarshampoo blijkt merkkeuze-involvement de belangrijkste. Dit zegt iets over de mate waarin de variantie in de data het best verklaard kan worden uit een lineaire combinatie van variabelen; de variantie in de merkkeuze-involvement-data kan bij haarshampoo gemakkelijker verklaard worden op grond van een lineaire combinatie van variabelen dan de variantie in de commitment-data. De variantie in de commitment data kan bij cassettebandjes makkelijker worden verklaard dan bij de merkkeuze-involvement-data.

Om een vergelijking te maken tussen de factoroplossing voor twee verschillende steekproeven is het noodzakelijk na te gaan of hetzelfde aantal factoren wordt gevonden, of dezelfde variabelen hoog scoren op de verschillende factoren en of dezelfde benamingen kunnen worden gebruikt voor de verschillende factoren voor elk van de steekproeven (Tabachnick en Fidell, 1989). Aangezien de resultaten voor wat betreft cassettebandjes en haarshampoo op de genoemde criteria met elkaar overeenkomen, kan geconcludeerd worden dat de gevonden factoroplossing voor cassettebandjes en haarshampoo nagenoeg identiek mag worden verondersteld.

Bij cassettebandjes blijkt een aantal items hoog te laden op zowel de factor commitment als de factor merkkeuze-involvement. Twee merkkeuze-involvement items hebben zelfs een hogere lading op de factor commitment dan op de factor merkkeuze-involvement (vraag 15 en 16). Op theoretische gronden - zij zijn namelijk afkomstig uit gevalideerde merkkeuze-involvement schalen - zijn deze items toch bij merkkeuze-involvement ingedeeld. In het geval van haarshampoo worden commitment en merkkeuze-involvement nagenoeg perfect van elkaar onderscheiden.

Het ontbreken van hoge correlaties (zoals reeds vermeld) tussen verschillende items van verschillende schalen (Bijlage 12) is tevens een ondersteuning voor de geconstateerde discriminante validiteit van de schalen.

Samenvattend kan worden geconcludeerd dat commitment, merkkeuze-involvement en deliberatie in het hoofdonderzoek op voldoende betrouwbare en valide wijze worden gemeten.

Tot slot van deze paragraaf geeft Tabel 7.4 een overzicht van de rekenkundige gemiddelden en de standaarddeviaties per schaal. 
Tabel 7.4: Overzicht gemiddelden en standaarddeviatie van commitment, merkkeuze-involvement en deliberatie bij cassettebandjes en haarshampoo

\begin{tabular}{lll}
\hline & Gemiddelde & Standaarddeviatie \\
\hline $\begin{array}{l}\text { commitment } \\
\text { cassettebandjes }\end{array}$ & 19.8 & 7.8 \\
haarshampoo & 21.3 & 7.8 \\
& & \\
merkkeuze-involvement & & \\
cassettebandjes & 39.7 & 12.4 \\
haarshampoo & 42.4 & 11.4 \\
deliberatie & & \\
cassettebandjes & 12.9 & 5.8 \\
haarshampoo & 13.8 & 5.5 \\
\hline
\end{tabular}

\subsubsection{Vergelijking tussen cassettebandjes en haarshampoo}

Bij de keuze van cassettebandjes en haarshampoo is er van uitgegaan dat deze produkten met name ten aanzien van de variabelen in het onderzoeksmodel verschillen. Hiernaast verschillen de beide produkten echter ook in andere opzichten van elkaar (zie paragraaf 6.2.1).

Om na te gaan of er inderdaad verschillen zijn tussen cassettebandjes en haarshampoo, voor wat betreft commitment, merkkeuze-involvement, deliberatie, de mate van tevredenheid en merktrouw, zal een vergelijking worden gemaakt tussen beide produkten. Verschillen tussen beide produkten zijn een indicatie dat de relatie tussen merktrouw en tevredenheid produktspecifiek is. Maar geen of weinig verschillen tussen beide produkten sluit produktspecificiteit van deze relatie niet uit. Er is echter geen directe reden om te veronderstellen dat de verschillen in de relatie tussen merktrouw en tevredenheid, voor de beide produkten zonder meer te wijten zijn aan de aard van de produkten.

Wanneer de gemiddelde scores van de belangrijkste variabelen (de mate van tevredenheid, kans op een herhalingsaankoop, de manier van heraankopen, de mate van ware merktrouw, de samenstelling van de evoked set, commitment, merkkeuze-involvement en deliberatie) worden vergeleken tussen de twee produkten, blijkt dat een statistisch significant verschil bestaat in het gemiddelde niveau van de mate van ware merktrouw, commitment, merkkeuze-involvement en deliberatie. De absolute verschillen zijn echter gering (Bijlage 14). Uit de analyses moet geconcludeerd worden dat de respondenten bij haarshampoo iets meer naar ware merktrouw neigen, dan bij cassettebandjes en dat het gemiddelde niveau van commitment, merkkeuze-involvement en deliberatie hoger is bij haarshampoo dan bij cassettebandjes.

Ten aanzien van de manier van het heraankopen van cassettebandjes en het heraankopen van haarshampoo kan geconcludeerd worden dat er geen verschil bestaat (Bijlage 15). 
Er blijkt wel een statistisch significant verschil te bestaan tussen cassettebandjes en haarshampoo voor wat betreft het al dan niet in overweging nemen van andere merken (de samenstelling van de evoked set), wanneer opnieuw een cassettebandje of haarshampoo wordt gekocht (zie ook Bijlage 15). Respondenten nemen in verschillende mate andere merken in overweging bij cassettebandjes als bij haarshampoo. Vijftig procent van de respondenten bij cassettebandjes neemt geen andere merken in overweging. Bij haarshampoo is dit $60 \%$.

Er is een gering maar wel statistisch significant verschil geconstateerd tussen de mate van commitment, merkkeuze-involvement, deliberatie en ware merktrouw en het in overweging nemen van andere merken. Bij haarshampoo liggen commitment, merkkeuze-involvement, deliberatie en ware merktrouw op een iets hoger niveau dan bij cassettebandjes, terwijl minder vaak een ander merk in overweging wordt genomen. Dit is echter voor ons een onvoldoende reden om te vooronderstellen dat de verklaring van de relatie tussen merktrouw en tevredenheid werkelijk verschilt tussen cassettebandjes en haarshampoo.

Er is wellicht wel een verschil in het niveau waarop relaties tussen ware merktrouw en tevredenheid kunnen worden vastgesteld. Er is echter geen reden om aan de nemen dat er een andere relatie tussen ware merktrouw en tevredenheid voor cassettebandjes zal bestaan dan voor haarshampoo. Hiermee wordt tevens gesteld dat er vooralsnog geen reden is om aan te nemen dat de aard van de relatie tussen merktrouw en tevredenheid, duidelijk produkt-specifiek is.

\subsubsection{Samenvatting van de belangrijkste totaalcijfers}

Schema 7.1: Overzicht van de eerste resultaten van de relatie tussen merktrouw en de mate van tevredenheid (gemiddelden en percentages)

\begin{tabular}{|c|c|c|c|}
\hline & $\begin{array}{l}\text { Cassette- } \\
\text { bandjes }\end{array}$ & $\begin{array}{l}\text { Haar- } \\
\text { shampoo }\end{array}$ & $\mathrm{p}$ \\
\hline gemiddelde merkkeuze-involvement (11-55) & 40 & 42 & ** \\
\hline gemiddelde deliberatie (6-30) & 13 & 14 & ** \\
\hline gemiddelde commitment $(6-30)$ & 20 & 21 & $*$ \\
\hline tevreden & $94 \%$ & $96 \%$ & ns \\
\hline kans op herhalingsaankoop $100 \%$ & $30 \%$ & $39 \%$ & $*$ \\
\hline steeds hetzelfde kopen & $38 \%$ & $42 \%$ & ns \\
\hline mate van ware merktrouw & $34 \%$ & $42 \%$ & * \\
\hline geen ander merk in overweging & $50 \%$ & $60 \%$ & $*$ \\
\hline geen ander merk indien uitverkocht & $51 \%$ & $61 \%$ & * \\
\hline geen ander merk bij prijsstijging eigen merk & $33 \%$ & $45 \%$ & * \\
\hline geen ander merk bij prijsdaling ander merk & $47 \%$ & $65 \%$ & $*$ \\
\hline voor speciaal gebruik & $57 \%$ & $54 \%$ & ns \\
\hline aantal respondenten $(100 \%)$ & 589 & 809 & \\
\hline
\end{tabular}

p : significantie niveau van het verschil tussen cassettebandjes en haarshampoo; (t-toetst voor gemiddelden en z-toetst (betrouwbaarheidsinterval) voor percentages); ${ }^{*}$ : $<.05 ;{ }^{* *}$ : $p<.001$; n.s.: niet statistisch significant 
Er blijkt een statistisch significant verschil te zijn tussen cassettebandjes en haarshampoo voor wat betreft alle variabelen uit Schema 7.1, behalve het percentage tevreden respondenten (dat is in beide gevallen ongeveer $95 \%$ ), het percentage respondenten dat steeds hetzelfde merk koopt (ongeveer $40 \%$ ) en het percentage respondenten dat het merk voor speciaal gebruik koopt (ongeveer 55\%).

Merkkeuze-involvement, deliberatie en commitment liggen op een hoger niveau bij shampoo dan bij cassettebandjes. Voor wat betreft haarshampoo wordt vaker met $100 \%$ zekerheid gesteld dat hetzelfde merk gekocht zal worden; is er vaker sprake van ware merktrouw; wordt vaker een ander merk in overweging genomen en wordt vaker een ander merk in overweging genomen indien het merk waarnaar de voorkeur uitgaat is uitverkocht, het merk waarnaar de voorkeur uitgaat in prijs is gestegen of een ander merk in prijs is gedaald. Dit in tegenstelling tot cassettebandjes. Het feit dat bij haarshampoo minder gemakkelijk andere merken in overweging worden genomen, kan ons inziens wijzen op een kleinere prijselasticiteit van de vraag. Dat bij een prijsstijging van het eigen merk vaker een ander merk in overweging wordt genomen dan bij een prijsdaling van een ander merk wijst ons inziens op een grotere gevoeligheid voor prijsveranderingen van het eigen merk dan van concurrerende merken. Maar kan ook wijzen op een grotere gevoeligheid voor prijsstijgingen dan voor prijsdalingen.

$\mathrm{Na}$ deze globale eerste bevindingen zal dieper worden ingegaan op de processen die de relatie tussen ware merktrouw en tevredenheid bepalen.

Allereerst moet echter worden opgemerkt dat bij het vervolg van de beschrijving van de resultaten:

1 alleen respondenten die aangegeven hebben tevreden te zijn met het laatst gekochte merk (vraag 4), in de analyses worden opgenomen.

Op basis van het feit dat het een onderzoek betreft naar de betekenis van tevredenheid bij de verklaring van ware merktrouw, worden respondenten die ontevreden zijn, of niet weten of zij tevreden dan wel ontevreden zijn, buiten beschouwing gelaten. Dit kan ook gezien onze vooronderstelling dat tevredenheid en ontevredenheid niet op én continuüm liggen. Bovendien gaat het om kleine aantallen respondenten die buiten gesloten worden (10 respondenten bij cassettebandjes en 19 respondenten bij haarshampoo);

2 commitment, merkkeuze-involvement en deliberatie per respondent worden bepaald via een simpele lineaire combinatie van de individuele items (voor de verantwoording paragraaf 7.1.2 en het vooronderzoek);

3 tevredenheid wordt gemeten in procenten op een continue schaal van $0 \%$ tot $100 \%$ (vraag 5b).

Hoewel tevredenheid zowel op een zevenpuntsschaal als op een procentschaal is gemeten, wordt in de verdere analyses gebruik gemaakt van de procentschaal. In de eerste plaats omdat tevredenheid dan als een continue variabele kan worden beschouwd, terwijl tevredenheid gemeten op een zevenpuntsschaal strikt genomen als een discrete variabele moet worden beschouwd. De procentschaal is tevens een meer gevoelige maat dan een zevenpuntsschaal en de procentschaal levert een grotere spreiding (variantie) voor de mate van tevredenheid op (zie tevens Bijlage 10). Bovendien 
zijn de scores op de procentschaal minder scheef verdeeld. (Voor een nadere analyse van de relatie tussen beide schalen zie Bijlage 16);

4 "merktrouw" voorlopig op vier manieren wordt gemeten:

- kans op een herhalingsaankoop: 'de kans dat u hetzelfde merk koopt als bij uw meest recente aankoop' (vraag 7).

- manier van heraankopen (vraag 9): steeds opnieuw hetzelfde merk kopen, af en toe veranderen van merk of voortdurend veranderen van merk.

- mate van ware merktrouw: variërend van een automatische herhalingsaankoop tot een weloverwogen keuze of ware merktrouw (vraag 10f).

- samenstelling van de evoked set: het al dan niet in overweging nemen van andere merken wanneer het produkt opnieuw wordt gekocht (vraag 35).

Hierbij wordt, met uitzondering van de mate van ware merktrouw, niet direct een onderscheid gemaakt tussen ware merktrouw en herhalingsaankopen.

Om redenen van eenvoud en inzicht zal allereerst aandacht worden besteed aan de relatie tussen merktrouw en tevredenheid met behulp van bivariate analyses. Vervolgens zullen, in hoofdstuk 8 , multivariate technieken worden gebruikt om een zo compleet mogelijk beeld te schetsen van de relatie tussen ware merktrouw en tevredenheid, waarbij dan tevens aandacht wordt besteed aan het onderscheid tussen manifeste en latente tevredenheid.

\subsection{Eerste analyse van de relatie tussen merktrouw en de mate van tevreden- heid}

Om inzicht te krijgen in de relatie tussen merktrouw en de mate van tevredenheid wordt nagegaan of er een verband bestaat (lineair of curvilineair; dit laatste met name in verband met eventuelen ristricties op de toe te passen analyse-technieken) tussen de kans op een herhalingsaankoop en de mate van tevredenheid, de manier van heraankopen en de mate van tevredenheid, de mate van ware merktrouw en de mate van tevredenheid en de samenstelling van de evoked set en de mate van tevredenheid (Bijlage 17).

Tevens wordt aandacht besteed aan de relatie tussen enerzijds tevredenheid en anderzijds commitment, merkkeuze-involvement en deliberatie. Allereerst zal worden geinventariseerd of rekening moet worden gehouden met curvilineaire verbanden. Hiertoe wordt de relatie tussen de verschillende relevante variabelen met kruistabellen geanalyseerd.

Bij de bespreking van deze resultaten moet vooraf worden opgemerkt dat respondenten, voor zover noodzakelijk, zijn ingedeeld in drie categorieën tevredenheid. Elke categorie vertegenwoordigt ongeveer één-derde van het totaal aantal respondenten. Respondenten die voor honderd procent tevreden zijn, zullen door ons worden gekarakteriseerd als zeer tevreden, respondenten die tussen de $75 \%$ en de $100 \%$ tevreden zijn, zullen worden gekarakteriseerd als aanzienlijk tevreden en de respondenten die voor $75 \%$ of minder tevreden zijn, worden redelijk tevreden genoemd. 


\subsubsection{Cassettebandjes}

De kans op een herhalingsaankoop en de mate van tevredenheid Naarmate respondenten meer tevreden zijn, neemt de kans dat zij hetzelfde merk cassettebandje opnieuw zullen kopen toe. Redelijk tevreden respondenten achten de kans dat hetzelfde merk opnieuw wordt gekocht over het algemeen niet groot. Aanzienlijk tevreden respondenten achten de kans dat hetzelfde merk opnieuw wordt gekocht over het algemeen groter en zeer tevreden respondenten geven over het algemeen aan dat een vrij grote kans bestaat dat hetzelfde merk opnieuw wordt gekocht (Tabel 1 in Bijlage 17).

\section{De manier van heraankopen en de mate van tevredenheid}

Wanneer respondenten meer tevreden zijn, zijn zij ook meer geneigd 'steeds opnieuw hetzelfde merk te kopen'.

Respondenten die niet zeer tevreden zijn, geven vaker aan 'af en toe van merk te veranderen', dan respondenten die zeer tevreden zijn (Tabel 2 in Bijlage 17).

Slechts een zeer beperkt aantal tevreden respondenten geeft aan voortdurend te wisselen van merk $(n=38)$. 'Voortdurend wisselen van merk' komt het minst voor wanneer de respondent zeer tevreden is. Hoewel dit vanzelfsprekend is, wisselen sommige zeer tevreden respondenten blijkbaar toch nog voortdurend van merk.

\section{De mate van ware merktrouw en de mate van tevredenheid}

Het koopgedrag van zeer tevreden en aanzienlijk tevreden respondenten kan het best omschreven worden als een weloverwogen keuze of ware merktrouw. Voor redelijk tevreden respondenten kan het koopgedrag het beste omschreven worden als een automatische herhalingsaankoop. Er is echter in deze bivariate analyse geen statistisch significant, direct verband tussen de mate van tevredenheid en de mate van ware merktrouw bij cassettebandjes (Tabel 3 in Bijlage 17). Dit sluit aan bij hypothese 1 waarin wordt gesteld dat tussen de mate van tevredenheid en ware merktrouw geen direct relatie bestaat.

\section{De samenstelling van de evoked set en de mate van tevredenheid}

Naarmate de tevredenheid van de respondent toeneemt, worden minder andere merken in overweging genomen bij een nieuwe aankoop (Tabel 4 in Bijlage 17).

Verder blijkt dat naarmate de mate van tevredenheid toeneemt, de mate van commitment (Tabel 5 in Bijlage 17) en de mate van merkkeuze-involvement toeneemt (Tabel 6 in Bijlage 17) toeneemt. Er is geen verband te constateren tussen de mate van tevredenheid en de mate van deliberatie (Tabel 7 in Bijlage 17). Het positieve verband tussen de mate van tevredenheid en commitment sluit aan bij hypothese 2, waarin wordt gesteld dat tussen de mate van tevredenheid en commitment een directe relatie bestaat.

Opgemerkt moet worden dat alle tot nu toe geconstateerde verbanden weliswaar statistisch significant, maar zwak zijn. Tevens zijn geen duidelijke curvilineaire verbanden geconstateerd. 
De kans op een herhalingsaankoop en de mate van tevredenheid

Wanneer respondenten meer tevreden zijn, neemt de kans dat zij hetzelfde merk haarshampoo opnieuw zullen kopen toe. Redelijk tevreden respondenten achten de kans dat hetzelfde merk opnieuw wordt gekocht over het algemeen niet groot. Aanzienlijk tevreden respondenten achten de kans dat hetzelfde merk opnieuw wordt gekocht over het algemeen groter en zeer tevreden respondenten geven veelal aan dat er een vrij grote kans bestaat dat hetzelfde merk opnieuw wordt gekocht (Tabel 8 in Bijlage 17).

\section{De manier van heraankopen en de mate van tevredenheid}

Respondenten die meer tevreden zijn, zijn meer geneigd steeds 'opnieuw hetzelfde merk te kopen'. Respondenten die niet zeer tevreden zijn, geven vaker aan 'af en toe van merk te veranderen' dan respondenten die zeer tevreden zijn. Slechts een zeer beperkt aantal respondenten geeft aan 'voortdurend te wisselen van merk' $(n=49)$. Het minst wordt er 'voortdurend van merk gewisseld' door zeer tevreden respondenten (maar ook dan wisselen sommigen nog voortdurend van merk; Tabel 9 in Bijlage 17).

\section{De mate van ware merktrouw en de mate van tevredenheid}

Het koopgedrag van zeer tevreden en aanzienlijk tevreden respondenten kan het best omschreven worden in de vorm van een weloverwogen keuze. Voor redelijk tevreden respondenten past een omschrijving in termen van een automatische herhalingsaankoop beter. Er blijkt hier wel een direct, positief verband te bestaan tussen de mate van tevredenheid en de mate van ware merktrouw bij haarshampoo: zeer tevreden respondenten vertonen bij haarshampoo vrij vaak ware merktrouw (in iets meer dan de helft van de gevallen (Tabel 10 in Bijlage 17). Dit sluit niet volledig aan bij hypothese 1 (tussen de mate van tevredenheid en ware merktrouw bestaat geen directe relatie).

\section{De samenstelling van de evoked set en de mate van tevredenheid}

Wanneer de tevredenheid van de respondent toeneemt, worden er minder andere merken in overweging genomen bij een nieuwe aankoop (Tabel 11 in Bijlage 17).

Tot slot blijkt dat naarmate de mate van tevredenheid toeneemt, de mate van commitment toeneemt (Tabel 12 in Bijlage 17) en dat naarmate tevredenheid toeneemt, ook de mate van merkkeuze-involvement toeneemt (Tabel 13 in Bijlage 17). Er is geen statistisch significant verband te constateren tussen de mate van tevredenheid en de mate van deliberatie (Tabel 14 in Bijlage 17). Het positieve verband tussen de mate van tevredenheid en commitment sluit ook nu aan bij hypothese 2 (tussen de mate van tevredenheid en commitment bestaat een directe relatie).

Ook hier moet worden opgemerkt dat de geconstateerde verbanden, hoewel statistisch significant, niet erg sterk zijn. Hiemaast zijn geen curvilineaire verbanden geconstateerd. 
Wanneer er wederom een vergelijking wordt gemaakt tussen de beide produkten valt in de eerste plaats op, dat er nauwelijks afwijkende patronen in de data zijn te onderscheiden (zie Schema 7.2). Dit wijst opnieuw op het feit dat de verklaring van de aard van de relatie tussen merktrouw en tevredenheid niet produkt specifiek is. Merktrouw is wellicht afhankelijker van het gedrag en de commitment van de individuele respondent, dan van het produkt.

Het enige verschil dat valt te ontdekken tussen beide produkten, is dat er bij haarshampoo wel een statistisch significant verband bestaat tussen de mate van tevredenheid en de mate van ware merktrouw, terwijl dit bij cassettebandjes niet het geval is. De associatie-maat (Tau b) is echter in beide gevallen klein (<.16) en er kan dus worden aangenomen dat er zowel bij haarshampoo als bij cassettebandjes geen duidelijk direct lineair verband bestaat tussen de mate van tevredenheid en de mate van ware merktrouw. Er ligt een groot aantal waarnemingen buiten de hoofddiagonaal zodat gesteld kan worden dat het verband niet perfect is.

In het vervolg wordt, indien er geen wezenlijke verschillen in de relatie tussen merktrouw en tevredenheid tussen cassettebandjes en haarshampoo zijn te constateren, hiervan niet langer expliciet melding gemaakt. Uiteraard zal een duidelijk verschil in de relatie wel nader worden toegelicht.

\subsubsection{Samenvatting van de gevonden relaties}

Schema 7.2: Overzicht van de empirisch gevonden relaties tussen merktrouw en tevredenheid

\begin{tabular}{lll}
\hline & Cassettebandjes & Haarshampoo \\
\hline kans op een herhalingsaankoop en mate van tevredenheid & positief & positief \\
manier van heraankopen en mate van tevredenheid & positief & positief \\
mate van ware merktrouw en mate van tevredenheid & geen & positief \\
samenstelling evoked set en mate van tevredenheid & negatief & negatief \\
commitment en mate van tevredenheid & positief & positief \\
merkkeuze-involvement en mate van tevredenheid & positief & positief \\
deliberatie en mate van tevredenheid & geen & geen \\
\hline
\end{tabular}

Uit de tot nu toe uitgevoerde analyses, waarvan de doelstelling was na te gaan of er een verband (lineair of curvilineair) bestaat tussen de mate van tevredenheid en de overige variabelen uit het onderzoeksmodel, zijn geen duidelijke curvilineaire verbanden naar voren gekomen. Dit betekent dat in het vervolg van de analyses kan worden uitgegaan van de vooronderstelling dat de verbanden tussen tevredenheid en de overige in het model opgenomen variabelen lineair zijn.

Hypothese 1 en hypothese 2 zijn in deze paragraaf aan een eerste onderzoek onderworpen. Hypothese 1 kan voorlopig worden bevestigd bij cassettebandjes maar niet bij haarshampoo (hoewel bij haarshampoo evenmin een duidelijk verband tussen de mate van tevredenheid en de mate van ware merktrouw kan worden geconstateerd). Hypothe- 
se 2 kan voor beide produkten voorlopig worden bevestigd. Deze en de overige hypothesen zullen in het vervolg van dit hoofdstuk en in het volgende hoofdstuk aan nader onderzoek worden onderworpen. De tot nu toe geconstateerde verbanden zijn zwak.

Mede gezien het geringe aantal waarnemingen van respondenten die zeggen 'voortdurend van merk te veranderen' ( $n=38$ bij cassettebandjes en $n=49$ bij haarshampoo) en de geformuleerde probleemstelling, zullen deze respondenten in het vervolg van de analyses voorlopig buiten beschouwing worden gelaten. Bovendien zijn van deze respondenten geen gegevens over de mate van ware merktrouw aanwezig, omdat bij het opstellen van de vragenlijst er vanuit is gegaan dat respondenten die te kennen geven 'voortdurend van merk te wisselen' niet zinvol kunnen aangeven welk mate van ware merktrouw (automatische heraankoop of weloverwogen keuze) zij laten zien. Zij wisselen immers voortdurend en elk antwoord, omtrent de manier waarop een merk herhaald wordt gekocht, lijkt ons dan willekeurig.

Nadere analyse van de relatie tussen merktrouw en de mate van tevredenheid

Om een duidelijker inzicht te krijgen in de relaties tussen de belangrijkste variabelen in het model wordt gebruik gemaakt van correlatie-analyses. Deze analyses maken het mogelijk de relatie tussen steeds twee variabelen uit het onderzoeksmodel duidelijker te kwantificeren dan mogelijk is met behulp van kruistabellen.

De kans op een herhalingsaankoop, de mate van ware merktrouw, de mate van tevredenheid, commitment, merkkeuze-involvement en deliberatie zijn de variabelen die in de analyse worden opgenomen. De manier van heraankopen en de samenstelling van de evoked set moeten in verband met het meetniveau van de variabelen (niet-metrisch) bij deze analyse buiten beschouwing blijven.

De relatie tussen de verschillende aspecten van de mate van ware merktrouw (vraag 10a $\mathrm{t} / \mathrm{m}$ vraag $10 \mathrm{e}$ ) en de samengestelde maat voor het meten van de mate van ware merktrouw (vraag 10f), zullen eveneens met behulp van correlatie-analyse worden bestudeerd.

Alle in de tekst van deze paragraaf vermelde correlatie-coëfficiënten zijn statistisch significant verschillend van nul $(\mathrm{p}<.001)$, tenzij anders vermeld. De correlatie-coëfficienten geven alleen aan of en in welke mate er een verband bestaat tussen twee variabelen. Conclusies ten aanzien van de causaliteitsrelatie tussen twee variabelen zijn hieruit niet zondermeer af te leiden.

\subsubsection{Cassettebandjes}

Commitment hangt, nagenoeg in dezelfde mate, samen met de kans op een herhalingsaankoop $(r=.60)$ als met de mate van ware merktrouw ( $r=.58)$. Naarmate de commitment bij een merk toeneemt, stijgt de kans op een herhalingsaankoop (waarbij het onduidelijk is of het gaat om ware merktrouw of om herhalingsaankopen) en is er vaker sprake van ware merktrouw. 
Dit laatste sluit goed aan bij hypothese 5 waarin gesteld wordt dat commitment leidt tot ware merktrouw.

Naarmate respondenten een hogere merkkeuze-involvement vertonen bij de merkkeuze, hebben zij een grotere commitment bij het merk. Merkkeuze-involvement en commitment hangen duidelijk met elkaar samen $(r=.75)$. Dit is voor de hand liggend. Immers merkkeuze-involvement en commitment zijn twee concepten die nauw met elkaar samenhangen, maar desondanks verschillend zijn. (Zie tevens paragraaf 4.3.).

Respondenten die een hogere merkkeuze-involvement hebben bij de merkkeuze blijken beter in staat over de merkkeuze na te denken; naarmate de merkkeuze-involvement toeneemt, neemt de deliberatie toe $(r=.48)$.

Merkkeuze-involvement en de kans op een herhalingsaankoop hangen in beperkte mate positief met elkaar samen ( $r=40)$. Indien de merkkeuze-merkkeuze-involvement toeneemt, stijgt de kans op een herhalingsaankoop. Merkkeuze-involvement en de mate van ware merktrouw hangen positief met elkaar samen $(r=.57)$. Enerzijds kan dit geïnterpreteerd worden door te stellen dat naarmate de merkkeuze-involvement toeneemt, de mate van ware merktrouw toeneemt. Anderzijds kan dit ook geïnterpreteerd worden door te vooronderstellen dat mede op basis van merkkeuze-involvement manifeste tevredenheid ontstaat, die er indirect, via commitment, voor zorgt dat de mate van ware merktrouw toeneemt. Nadere analyses in hoofdstuk 8 zullen genuanceerder inzicht moeten verschaffen. In ieder geval, kan geconcludeerd worden dat ook merkkeuze-involvement van betekenis is voor ware merktrouw.

Deliberatie hangt in beperkte mate positief samen met de mate van ware merktrouw $(r=32)$. Hieruit kan voorlopig geconcludeerd worden (vergelijk merkkeuze-involvement) dat ook deliberatie een rol speelt bij ware merktrouw. De exacte betekenis zal in hoofdstuk 8 nader worden onderzocht.

Deliberatie hangt niet statistisch significant samen met de kans op een herhalingsaankoop $(r=.11)$. De kans op een herhalingsaankoop blijkt niet toe te nemen wanneer een respondent meer delibereert.

Wanneer een respondent meer tevreden is met het gekochte merk, is de kans op een herhalingsaankoop enigszins groter $(r=.42)$. Hoe tevredener een respondent, des te meer kans dat hij/zij zich in de situatie van een weloverwogen keuze of ware merktrouw begeeft $(r=.18)$. Hoewel de correlatie-coëfficiënt statistisch significant is, is het verband (bijna) te verwaarlozen. Dit sluit aan bij hypothese 1 waarin verondersteld werd dat er geen direct verband is tussen de mate van tevredenheid en de mate van ware merktrouw.

De mate van tevredenheid en commitment blijken in geringe mate positief met elkaar samen te hangen ( $r=.28)$. Naarmate de mate van tevredenheid toeneemt, neemt de commitment toe. Dit sluit aan bij hypothese 2 waarin een directe relatie tussen de mate van tevredenheid en commitment wordt verondersteld.

Naarmate voor een respondent de kans toeneemt dat bij een volgende aankoop hetzelfde merk zal worden gekocht, herkent deze respondent zich meer in de omschrijving van zijn/haar koopsituatie als een weloverwogen keuze $(r=.38)$. Met andere woorden naar- 
mate de kans op een herhalingsaankoop stijgt, neemt de mate van ware merktrouw enigszins toe. Dit betekent dat ware merktrouwe respondenten met een iets grotere zekerheid de volgende keer hetzelfde merk kopen dan minder ware merktrouwe respondenten. Dit komt overeen met onze verwachtingen en sluit aan bij het feit dat ware merktrouwe respondenten nadrukkelijker aan de merkkeuze willen vasthouden dan minder ware merktrouwe respondenten.

De tot nu toe vermelde verbanden tussen de verschillende variabelen ( voor een overzicht zie Tabel 7.5) uit het onderzoeksmodel zijn verre van perfect; dit betekent dat de tot nu toe geformuleerde bevindingen met de nodige voorzichtigheid moeten worden geïnterpreteerd.

Tabel 7.5: Correlaties (Pearson corr) tussen merkkeuze-involvement (INV), commitment (COM), deliberatie (DEL), tevredenheid (TEV), de kans op een herhalingsaankoop (KH) en de mate van ware merktrouw (MT)

\begin{tabular}{llllll}
\hline Correlatie: & COM & DEL & TEV & KH & MT \\
\hline INV & $.7470^{* *}$ & $.4841^{* *}$ & $.1930^{* *}$ & $.3975^{* *}$ & $.5674^{* *}$ \\
COM & & $.2699^{* *}$ & $.2830^{* *}$ & $.5999^{* *}$ & $.5811^{* *}$ \\
DEL & & & .0811 & .1148 & $.3161^{* *}$ \\
TEV & & & & $.4237^{* *}$ & $.1787^{* *}$ \\
KH & & & & $.3830^{* *}$ \\
\hline
\end{tabular}

$n=316 ; * * p<.001$

De mate van ware merktrouw (vraag 10f) is een samengestelde maat (zie Tabel 7.6). De maat is samengesteld uit verschillende aspecten van ware merktrouw, die ook afzonderlijk zijn gemeten (vraag 10a tot en met vraag 10e). Er kan verwacht worden dat de afzonderlijke onderdelen van de samengestelde maat van de mate van ware merktrouw, samenhangen met de samengestelde maat. Dit blijkt echter niet altijd te gelden. Alleen of de respondent min of meer toevallig met het merk in aanraking is gekomen of een bewuste keuze heeft gemaakt voor het merk $(r=.53)$ en of het voor de respondent makkelijk of moeilijk is om van merk te wisselen $(r=.62)$ hangen positief samen met de samengestelde maat. De overige afzonderlijke aspecten van de mate van ware merktrouw blijken niet samen te hangen met de samengestelde maat voor de mate van ware merktrouw (zie Bijlage 19).

Opvallend is dat de manier waarop de respondent met het merk in aanraking is gekomen, het begin is van de situatieschets en dat het gemak waarmee van merk wordt gewisseld het einde is van de situatieschets bij de samengestelde maat. Dit zou kunnen wijzen op een 'primacy-' en een 'recency-effect' bij het meten van de mate van ware merktrouw op deze wijze. Dat wil zeggen, dat het antwoord op de eerste en de laatste voorafgaande vraag over de mate van ware merktrouw het beste worden herinnerd en derhalve gereproduceerd.

Ook zou kunnen worden verondersteld dat de manier waarop men met het merk in aanrakııg is gekomen en het gemak waarmee van merk wordt gewisseld, inderdaad de twee belangrijkste aspecten zijn van de mate van ware merktrouw. Beide afzonderlijke aspecten zouden dan vervolgens gezamenlijk als indicator voor een nieuwe samengestel- 
de maat kunnen gaan dienen. Deze weg zijn wij niet ingeslagen. Onze oorspronkelijke samengestelde maat beschouwen wij, op basis van de theorie, voor als nog, als de beste maat voor de mate van ware merktrouw en deze maat zal voorlopig bij het vervolg van de analyse centraal blijven staan.

Tabel 7.6: Correlaties (Pearson corr) tussen de mate van merktrouw en de afzonderlijke aspecten van mate van ware merktrouw (MT)

\begin{tabular}{ll}
\hline Correlatie: & MT $(10 \mathrm{f})^{*}$ \\
\hline toeval-bewuste keuze (10a) & $.5283^{* *}$ \\
automatisch-denkt na over keuze (10b) & .1025 \\
belangrijk-niet belangrijk (10c) & .0580 \\
wel gehecht-niet gehecht $(10 \mathrm{~d})$ & .0645 \\
gemakkelijk-moeilijk veranderen $(10 \mathrm{e})$ & $.6214^{* *}$ \\
\hline
\end{tabular}

*: nummer van de oorspronkelijke vraag; $n=316$; **: $p<.001$

\subsubsection{Haarshampoo}

De bevindingen bij haarshampoo worden kort weergegeven omdat de overeenkomsten met de bevindingen bij cassettebandjes groot zijn (voor een overzicht zie Tabel 7.7).

Commitment hangt, sterker nog dan merkkeuze-involvement, positief samen met de kans op een herhalingsaankoop ( $r=.49)$ en de mate van ware merktrouw $(r=.56)$. Als de commitment aan een merk groter wordt, stijgt de kans op een herhalingsaankoop en is er vaker sprake van ware merktrouw. Dit laatste sluit aan bij hypothese 5, waarin gesteld wordt dat commitment leidt tot ware merktrouw.

Wanneer de merkkeuze-involvement van de respondent bij de merkkeuze hoger is, heeft hij/zij een grotere commitment ten aanzien van het merk $(r=.71)$ en vertoont hij/zij iets meer deliberatie $(r=.40)$. Tevens geldt dat dan de kans op een herhalingsaankoop enigszins toeneemt $(r=.31)$ en de respondent vaker ware merktrouw vertoont $(r=.51)$. Deze positieve verbanden zijn aanleiding te veronderstellen dat merkkeuze-involvement een rol speelt bij de verklaring van ware merktrouw.

Deliberatie hangt in beperkte mate samen met de mate van ware merktrouw ( $r=.25$ ) maar hangt niet statistisch significant samen met de kans op een herhalingsaankoop $(r=.04)$.

Naarmate een persoon meer tevreden is met het gekochte merk, is de kans op een herhalingsaankoop enigszins groter $(r=.47)$. Indien een persoon meer tevreden is met het gekochte merk, dan hangt dit in zeer beperkte positieve mate samen met de manier waarop die persoon opnieuw het merk koopt $(r=.17)$. Dit betekent dat hoe tevredener een persoon, des te waarschijnlijker deze zich herkent in de situatie van ware merktrouw. Tevens wordt geconstateerd dat de mate van tevredenheid en commitment even- 
eens enigszins positief met elkaar samenhangen ( $r=.28)$. Dit laatste sluit aan bij hypothese 2.

Een respondent die zich beter herkent in de omschrijving van zijn/haar koopsituatie als een weloverwogen keuze, is enigszins meer zeker van de kans dat bij een volgende aankoop hetzelfde merk zal worden gekocht ( $r=.27)$.

Tabel 7.7: Correlaties (Pearson corr) tussen merkkeuze-involvement (INV), commitment (COM), deliberatie (DEL), tevredenheid (TEV), de kans op een herhalingsaankoop (KH) en de mate van ware merktrouw (MT)

\begin{tabular}{llllll}
\hline Correlatie: & COM & DEL & TEV & KH & MT \\
\hline INV & $.7135^{* *}$ & $.4009^{* *}$ & $.1951^{* *}$ & $.3080^{* *}$ & $.5073^{* *}$ \\
COM & & $.1771^{* *}$ & $.2752^{* *}$ & $.4897^{* *}$ & $.5605^{* *}$ \\
DEL & & & .0237 & .0428 & $.2519^{* *}$ \\
TEV & & & & $.4745^{* *}$ & $.1699^{* *}$ \\
KH & & & & & $.2721^{* *}$ \\
\hline
\end{tabular}

$\mathrm{n}=468 ; * *: \mathrm{p}<.001$

Ook bij haarshampoo blijken de bewustheid van de keuze voor een merk $(r=.41)$ en de moeilijkheid om van merk te wisselen $(r=.60)$, positief samen te hangen met de samengestelde maat van de mate van ware merktrouw. De overige afzonderlijke aspecten van de mate van ware merktrouw blijken niet samen te hangen met de samengestelde maat voor de mate van ware merktrouw (zie Tabel 7.8).

Tabel 7.8: Correlaties (Pearson corr) tussen de mate van merktrouw en de afzonderlijke aspecten van mate van ware merktrouw

\begin{tabular}{ll}
\hline Correlatie: & MT (10f)* \\
\hline toeval-bewuste keuze (10a) & $.4135^{* *}$ \\
automatisch-denkt na over keuze (10b) & -.0146 \\
belangrijk-niet belangrijk (10c) & -.1038 \\
wel gehecht-niet gehecht $(10 \mathrm{~d})$ & -.1920 \\
gemakkelijk-moeilijk veranderen (10e) & $.6020^{* *}$ \\
\hline
\end{tabular}

*: nummer van de oorspronkelijke vraag; $n=468 ; * *$ : $p<.001$ 
Schema 7.3: Overzicht van de relatie tussen merktrouw en de mate van tevredenheid bij tevreden respondenten die niet voortdurend van merk wisselen (correlatie-coëfficiënten)

\begin{tabular}{lll}
\hline & Cassettebandjes & Haarshampoo \\
\hline kans op een herhalingsaankoop en mate van tevredenheid & $.42^{* *}$ & $.47^{* *}$ \\
mate van ware merktrouw en mate van tevredenheid & $.18^{* *}$ & $.17^{* *}$ \\
mate van ware merktrouw en commitment & $.58^{* *}$ & $.56^{* *}$ \\
commitment en mate van tevredenheid & $.28^{* *}$ & $.28^{* *}$ \\
merkkeuze-involvement en mate van tevredenheid & $.19^{* *}$ & $.20^{* *}$ \\
deliberatie en mate van tevredenheid & .08 & .02 \\
$\mathrm{n}:$ & 316 & 468 \\
\hline
\end{tabular}

**: $p<.001$

In Schema 7.3. wordt een overzicht gegeven van de tot nu toe gevonden resultaten, waarbij tevens een vergelijking wordt gemaakt tussen cassettebandjes en haarshampoo. Meest opvallend is dat de correlatie-coëfficiënten tussen tevredenheid en de overige variabelen laag zijn (de relatie tussen de kans op een herhalingsaankoop en de mate van tevredenheid enigszins uitgezonderd). Dit betekent dat er na de tot nu toe verrichte bivariate analyses geen duidelijke verbanden zijn geconstateerd tussen tevredenheid en de overige in het onderzoeksmodel opgenomen variabelen. En dat de tot nu toe veronderstelde effecten met de nodige voorzichtigheid moeten worden geïnterpreteerd.

De correlatie-coëfficiënt tussen de mate van tevredenheid en de mate van ware merktrouw is zeer laag; de gedeelde variantie bedraagt slechts ongeveer $3 \%$. Voorlopig kan dus geconcludeerd worden dat voor de gehele steekproef de mate van tevredenheid en de mate van ware merktrouw niet direct iets met elkaar te maken lijken te hebben. Daarmee wordt hypothese 1 bevestigd.

De gedeelde variantie tussen de mate van tevredenheid en de kans op een herhalingsaankoop is ongeveer $20 \%$. Op grond hiervan kan verondersteld worden dat tevredenheid directer van invloed is op de kans op een herhalingsaankoop dan op de mate van ware merktrouw.

Onze bevindingen komen overeen met bevindingen uit andere onderzoeken naar de relatie tussen de mate van tevredenheid en merktrouw waarbij geen onderscheid werd gemaakt tussen ware merktrouw en herhalingsaankopen enerzijds en manifeste en latente tevredenheid anderzijds. In deze onderzoeken wordt steeds een positieve maar niet perfecte relatie tussen de mate van tevredenheid en merktrouw gevonden (zie paragraaf 3.6).

Commitment en de mate van ware merktrouw hangen duidelijk positief met elkaar samen. Dit, tezamen met door ons veronderstelde causaliteit, is een indicatie dat hypothese $5 \mathrm{kan}$ worden geaccepteerd. Hierin wordt gesteld dat commitment leidt tot ware merktrouw. De relatie tussen beide variabelen is echter niet perfect. Bovendien blijken de kans op een herhalingsaankoop en commitment nagenoeg in dezelfde mate met elkaar samen te hangen als de mate van ware merktrouw en commitment. 
Tevredenheid en commitment hangen marginaal positief met elkaar samen. Dit wil zeggen dat wanneer de mate van tevredenheid groter is, de commitment aan het merk eveneens groter is (maar niet veel). Hypothese 2 wordt hierdoor, hoewel geenszins overtuigend, bevestigd. Merkkeuze-involvement en tevredenheid hangen ook met elkaar samen, maar het verband is minder sterk dan tussen commitment en tevredenheid. Deliberatie en tevredenheid blijken niet met elkaar samen te hangen.

In aansluiting bij onze assumptie worden merkkeuze-involvement en deliberatie opgevat als de indicatoren van manifeste tevredenheid. Er is door ons geen verband verondersteld tussen de mate van tevredenheid en de mate van merkkeuze-involvement of deliberatie, elk afzonderlijk.

Onze bevindingen sluiten voorlopig aan bij hypothese 1 en hypothese 2 (hoewel zeker voor wat betreft deze laatste hypothese niet overtuigend), die betrekking hebben op de mate van tevredenheid. Tevens sluiten onze bevindingen aan bij hypothese 5 . In het volgende hoofdstuk zal de betekenis van de soort tevredenheid (manifest of latent) bij de verklaring van ware merktrouw nader worden bestudeerd. Aan de overeenkomst in de sterkte van de relatie tussen commitment en ware merktrouw en de relatie tussen commitment en de kans op een herhalingsaankoop zal in het volgende hoofdstuk eveneens nader aandacht worden besteed.

\subsection{Conclusie}

Voor zowel cassettebandjes als haarshampoo geldt dat ruim negentig procent van de respondenten tevreden is met het laatst gekochte merk. Eén-derde is zelfs voor $100 \%$ tevreden. Tenminste $30 \%$ van het totaal aantal respondenten is voor $100 \%$ zeker dat ze hetzelfde merk opnieuw zullen gaan kopen. Ruim één-derde vindt zijn/haar koopgedrag het best omschreven als een ware merktrouw.

Wanneer cassettebandjes en haarshampoo nauwkeurig met elkaar worden vergeleken blijkt echter dat respondenten iets meer gecommitteerd zijn aan en iets meer geïnvolveerd zijn bij haarshampoo dan bij cassettebandjes. Ook delibereren respondenten meer over de merkkeuze van haarshampoo dan van cassettebandjes. Respondenten zullen vaker met $100 \%$ zekerheid weer hetzelfde merk haarshampoo kopen en geven vaker aan waarlijk merktrouw te zijn aan een bepaald merk haarshampoo, in vergelijking met cassettebandjes. Daarentegen nemen de respondenten bij haarshampoo vaker een ander merk in overweging (maar kopen het klaarblijkelijk toch niet).

Op grond van de frequentie-verdelingen wordt geconcludeerd dat er voldoende spreiding in de data aanwezig is om de relatie tussen merktrouw en tevredenheid nader te kunnen onderzoeken op een verantwoorde manier.

Vervolgens zijn een aantal bivariate relaties vastgesteld tussen tevredenheid en de overige in het model opgenomen variabelen: wanneer de tevredenheid toeneemt, nemen de kans op een herhalingsaankoop, de mate van ware merktrouw, commitment en merkkeu- 
ze-involvement toe, wordt vaker steeds opnieuw hetzelfde merk gekocht en wordt minder vaak een ander merk in overweging genomen. Belangrijke conclusies zijn verder dat er geen curvilineaire verbanden tussen de variabelen vastgesteld kunnen worden en er geen duidelijke verschillen in de sterkte van de bivariate relaties geconstateerd worden tussen de twee produkten.

Uit de vergelijking van deze bevindingen over de twee produkten zou afgeleid kunnen worden, dat de verklaring van ware merktrouw en de rol van tevredenheid daarbij, niet zozeer produktspecifiek zal zijn, maar eerder afhankelijk van de respondent zal zijn.

Tevens is vastgesteld dat hypothese 1, hypothese 2 en hypothese 5, voorlopig in meer of mindere mate, kunnen worden bevestigd. Tussen de mate van tevredenheid en ware merktrouw blijkt geen directe relatie te bestaan; tussen de mate van tevredenheid en commitment blijkt een positieve relatie te bestaan en tussen de commitment en ware merktrouw blijkt een duidelijk positieve relatie te bestaan. De positieve relatie tussen de mate van tevredenheid en commitment blijkt marginaal. De overige relaties zijn echter ook niet sterk.

In aansluiting bij ons onderzoeksmodel kan verondersteld worden dat de relatie merktrouw en tevredenheid complexer is dan een simpele directe relatie. Wij menen bovendien dat het onderscheid tussen manifeste en latente tevredenheid het inzicht in de relatie tussen merktrouw en tevredenheid zal verbeteren. Hieraan zal in hoofdstuk 8 meer aandacht worden besteed. 


\section{$8 \quad$ Nadere resultaten van het empirisch onderzoek: ware merktrouw en de soort tevredenheid}

\subsection{Inleiding}

Bij de eerste analyses van de resultaten van dit onderzoek heeft de relatie tussen ware merktrouw en de mate van tevredenheid centraal gestaan. Hypothese 1 en hypothese 2 kunnen volgens ons worden bevestigd. Dit betekent dat tussen de mate van tevredenheid en ware merktrouw geen directe relatie bestaat. Tussen de mate van tevredenheid en commitment bestaat wel een directe relatie (hoewel marginaal). Tevens kan hypothese 5 worden bevestigd. Er is een duidelijk positieve relatie tussen commitment en ware merktrouw geconstateerd. De mate van tevredenheid blijkt voorlopig nauwelijks van invloed op ware merktrouw.

In dit hoofdstuk willen wij ons concentreren op de rol van de soort tevredenheid bij de verklaring van ware merktrouw (het herhaald aankopen van een merk gebaseerd op commitment bij het merk): manifeste tevredenheid of latente tevredenheid.

Manifeste tevredenheid is in onze opvatting een tevredenheidsoordeel dat gebaseerd is op het uitgebreid doorlopen van het evaluatieproces van een merk. Hiervoor is het noodzakelijk dat de consument over voldoende motivatie en capaciteit beschikt om dit proces uitgebreid te doorlopen. Consumenten die niet beschikken over voldoende motivatie en/of capaciteit, zullen een merk niet uitgebreid evalueren en geen manifest, maar een latent tevredenheidsoordeel hebben. Dit latente tevredenheidsoordeel houdt niet meer in dan de impliciete acceptatie van het merk. Merkkeuze-involvement en deliberatie kunnen volgens ons in aansluiting bij onze assumptie worden gebruikt als indicatoren van de soort tevredenheid.

Hypothese 3 en hypothese 4 staan in dit hoofdstuk in eerste instantie centraal. Dit wil zeggen dat getoetst moet worden of er geen directe relatie tussen manifeste tevredenheid en ware merktrouw bestaat en of manifeste tevredenheid tot commitment leidt. Om deze hypothesen zinvol te toetsen moet een vergelijking worden gemaakt tussen de rol van manifeste tevredenheid en latente tevredenheid.

In het vervolg van de beschrijving van de resultaten van ons onderzoek staan in aansluiting op de centrale probleemstelling en de hypothesen de mate van ware merktrouw (als operationalisatie van het concept ware merktrouw), de soort tevredenheid en de mate van commitment centraal. 


\subsubsection{Ware merktrouw}

Hypothese 3 en hypothese 4 kunnen worden getoetst door na te gaan of de sterkte van de relatie tussen de mate van tevredenheid en commitment en de mate van tevredenheid en de mate van ware merktrouw afhankelijk is van de soort tevredenheid. (Dit wil zeggen dat wordt nagegaan of er een moderator-effect is van de soort tevredenheid op de relatie tussen de mate van tevredenheid en commitment en de mate van tevredenheid en de mate van ware merktrouw.)

Hiertoe wordt de totale groep respondenten in twee subgroepen ingedeeld. De ene groep wordt gekenmerkt door manifeste tevredenheid, de andere groep wordt gekenmerkt door latente tevredenheid. De soort tevredenheid is - zoals gezegd - afhankelijk van de uitgebreidheid waarmee de consument het evaluatieproces doorloopt (de mate van elaboratie). Een consument dient over voldoende motivatie en capaciteit te beschikken om het evaluatie-proces van een merk uitgebreid te doorlopen. Merkkeuze-involvement en deliberatie worden als indicatoren voor de motivatie en capaciteit gebruikt en dus als indicatoren voor de soort tevredenheid (zie tevens paragraaf 3.3). Hierbij wordt ervan uitgegaan dat zowel motivatie als capaciteit van belang zijn bij het bepalen van de soort tevredenheid.

De concrete indeling in de twee subgroepen, de één met manifest tevreden respondenten en de ander met latent tevreden respondenten verloopt als volgt: de totale steekproef, uiteraard per produkt, wordt eerst voor zowel merkkeuze-involvement als deliberatie gesplitst in drie nagenoeg even grote groepen. Dat wil zeggen dat voor bijvoorbeeld merkkeuze-involvement één derde van de respondenten, met de laagste score, een subgroep vormen en dat één derde van de respondenten, met de hoogste score, een subgroep vormen. Zo ontstaan drie subgroepen merkkeuze-involvement. Eén met een gemiddeld lage score, één met een gemiddeld medium score en één met een gemiddeld hoge score voor merkkeuze-involvement. Hetzelfde is voor de deliberatiescores gedaan. Vervolgens worden die respondenten die een hoge merkkeuze-involvementscore en een hoge deliberatiescore, of een hoge score op éen van beide variabelen en medium score op de andere variabele, ingedeeld bij de groep veel elaboratie en dus manifeste tevredenheid. De respondenten die een lage merkkeuze-involvementscore en een lage deliberatiescore, of een lage score op één van de variabelen en een mediumscore op de andere variabelen hebben, worden ingedeeld bij de groep weinig elaboratie en dus latente tevredenheid.

Voor beide subgroepen wordt de correlatie-coëfficiënt berekend tussen de mate van tevredenheid en commitment en de mate van tevredenheid en de mate van ware merktrouw. Of er een statistisch significant verschil bestaat tussen de correlatie-coëfficiënt van de groep met manifeste tevredenheid en de groep met latente tevredenheid, wordt getoetst met een Fisher Z-toets. De resultaten van deze analyse staan vermeld in Tabel $8.1 \mathrm{a} / \mathrm{b}$. 

ware merktrouw (MT) bij latente en manifeste tevredenheid voor cassettebandjes.

Cassettebandjes

\begin{tabular}{llll}
\hline Respondenten & T-C & T-MT & $n$ \\
latente tevredenheid & .15 & .18 & 113 \\
manifeste tevredenheid & $.34^{* *}$ & .05 & 134 \\
Fisher Z & 1.53 & 1.00 & \\
\hline
\end{tabular}

**: $p<.001$

Tabel 8.1b: Correlatie tussen tevredenheid $(T)$ en commitment $(C)$ en tevredenheid en de mate van ware merktrouw (MT) bij bij latente en manifeste tevredenheid voor haarshampoo.

\begin{tabular}{llll}
\hline Haarshampoo & & & \\
\hline Respondenten & T-C & T-MT & $\mathrm{n}$ \\
& & & \\
latente tevredenheid & $.20^{*}$ & $.19^{*}$ & 182 \\
manifeste tevredenheid & $.28^{* *}$ & .05 & 179 \\
Fisher Z & .81 & .91 & \\
\hline
\end{tabular}

*: $\mathrm{p}<.01 ; * * \mathrm{p}<.001$

Uit Tabel $8.1 \mathrm{a} / \mathrm{b}$ blijkt dat de relatie tussen de mate van tevredenheid en commitment en de mate van tevredenheid en de mate van ware merktrouw niet afhankelijk is van de soort tevredenheid (Fisher $\mathrm{Z}$ is niet statistisch significant).

Dit wil zeggen dat het geen verschil maakt of respondenten manifest of latent tevreden zijn voor wat betreft de relatie tussen de mate van tevredenheid en commitment en de mate van tevredenheid en de mate van ware merktrouw. Bij manifest tevreden respondenten is de directe relatie tussen de mate van tevredenheid en commitment en de directe relatie tussen de mate van tevredenheid en de mate van ware merktrouw niet (statistisch significant) sterker dan bij latent tevreden respondenten.

Hiervoor is aangetoond dat er bij de gehanteerde indeling van de respondenten naar soort tevredenheid (latent of manifest) geen moderator-effect bestaat. Het is echter mogelijk dat dit veroorzaakt wordt door de gehanteerde indeling en dat een andere indeling tot andere resultaten leidt. Daarom wordt het moderator-effect van de soort tevredenheid nader onderzocht. Dit gebeurt met behulp van hiërarchische regressieanalyse.

Hiërarchische regressie-analyse is een methode om het moderator-effect van een variabele op de relatie tussen twee of meer andere variabelen te identificeren. Cohen en Cohen (1983) tonen aan dat het moderator-effect van $\mathrm{Z}$ op de relatie tussen $\mathrm{X}$ en $\mathrm{Y}$ kan worden aangetoond in twee stappen. Tijdens de eerste stap wordt $Y$ geregresseerd op X en $Z$. Tijdens de tweede stap wordt $Y$ geregresseerd op $X, Z$ en XZ (het produkt van X en $Z$ ). Als het percentage verklaarde variantie van $Y$, van stap 1 naar stap 2 , statistisch 
significant toeneemt, mag geconcludeerd worden dat $\mathrm{Z}$ een moderator is van de relatie tussen X en Y. Cronbach (1986) stelt dat multicollineariteit geen afbreuk doet aan de kracht ('power') van de significantie toets voor het verschil in percentages verklaarde variantie. Wel raadt Cronbach (1986) aan gebruik te maken van afwijkingsscores (ruwe score - gemiddelde) voor de voorspellende variabelen.

Het correct toepassen van (hiërarchische) regressie analyse is gebaseerd op een aantal vooronderstellingen. Er moet daarom gecontroleerd worden in hoeverre aan de vooronderstellingen wordt voldaan. De meest gebruikelijke en voor dit onderzoek relevante vooronderstellingen zijn:

- veronderstelde causaliteit in de relatie tussen variabelen;

- opnemen van alle relevante variabelen;

- variabelen geschaald op tenminste interval-niveau;

- een lineaire relatie tussen onafhankelijke(n) en afhankelijke(n) variabelen;

- een homogene variantie in de storingstermen;

- een normale verdeling van de storingstermen;

- geen multicollineariteit tussen variabelen.

Daarnaast is gecontroleerd op zgn. 'outliers'. Dit zijn respondenten die de schatting van het model kunnen verstoren vanwege het feit dat de gestandaardiseerde waarde van de storingsterm groter is dan 3 .

Uiteraard wordt er een causale relatie verondersteld tussen de variabelen in het te toetsen model. Voor zover mogelijk zijn alle relevante variabelen in het model opgenomen. Reeds eerder is al geconstateerd, dat de relatie tussen onafhankelijke en afhankelijke variabele(n) lineair kan worden verondersteld (zie paragraaf 7.2.1 en 7.2.2.). Er zijn geen problemen geconstateerd voor wat betreft de homogene variantie en de normale verdeling van de storingstermen. Het zeer beperkte aantal outliers (in geen geval meer dan 6 bij de schatting van de algemene modellen) is, vanwege hun geringe aantal en invloed, niet uit de analyse verwijderd.

Om te bepalen of de relatie tussen de mate van tevredenheid en commitment afhankelijk is van de soort tevredenheid (welke bepaald wordt door de mate van elaboratie) moeten twee modellen worden geschat: Model 8.1 en Model 8.2. Merkkeuze-involvement en deliberatie worden hierin als indicatoren van de soort tevredenheid opgenomen. Hierbij wordt ervan uitgegaan dat merkkeuze-involvement en deliberatie interacteren: enerzijds zal indien één van beiden afwezig is kan er geen sprake zijn van enige elaboratie; anderzijds zal het effect van beide gezamenlijk groter zijn dan de som der delen.

Wanneer Model 8.2 een statistisch significant hogere verklaarde variantie heeft dan Model 8.1 betekent dit dat de relatie tussen de mate van tevredenheid en commitment afhankelijk is van de soort tevredenheid. Dat wil zeggen dat er een moderator-effect is van elaboratie. Indien Model 8.2 geen statistisch significant hogere verklaarde variantie heeft dan Model 8.1 moet geconcludeerd worden dat het effect van de mate van tevredenheid op commitment niet afhankelijk is van de soort tevredenheid. 


$$
C=b_{0}+b_{1}(T)+b_{2}(I)+b_{3}(D)+b_{4}(T x I x D)
$$

Hierbij geldt: C: commitment; T: tevredenheid; I: merkkeuze-involvement; D: deliberatie

Wanneer een moderator-effect wordt geconstateerd op grond van een statistisch significant verschil in percentage verklaarde variantie, moet voor de interpretatie dit effect nader worden onderzocht. Het meest voor de hand liggend is hierbij gebruik te maken van partiële correlaties (zie o.a. Nie et al., 1975). Partiële correlatie geven het verband aan tussen een specifieke onafhankelijke variabele (in dit geval de moderator; de soort tevredenheid) en de afhankelijke variabele terwijl, de invloed van andere onafhankelijke variabelen op de specifieke onafhankelijke en afhankelijke variabele wordt uitgeschakeld.

Op analoge wijze kan het moderator-effect van de soort tevredenheid op de relatie tussen de mate van tevredenheid en de mate van ware merktrouw worden nagegaan. Hiervoor moeten Model 8.3 en 8.4 worden geschat en met elkaar worden vergeleken.

[8.3] $M T=b_{0}+b_{1}(T)+b_{2}(I)+b_{3}(D)$

[8.4] $M T=b_{0}+b_{1}(T)+b_{2}(I)+b_{3}(D)+b_{4}(T x I x D)$

Hierbij geldt: MT: mate van ware merktrouw; T: tevredenheid; I: merkkeuze-involvement; D: deliberatie

De resultaten van deze analyses staan weergegeven in Tabel $8.2 \mathrm{a} / \mathrm{b}$. 
Tabel 8.2a: Resultaten van de hiërarchische regressie-analyse: het effect van de soort tevredenheid op de relatie tussen de mate van tevredenheid en de afhankelijke variabele commitment en ware merktrouw bij cassettebandjes

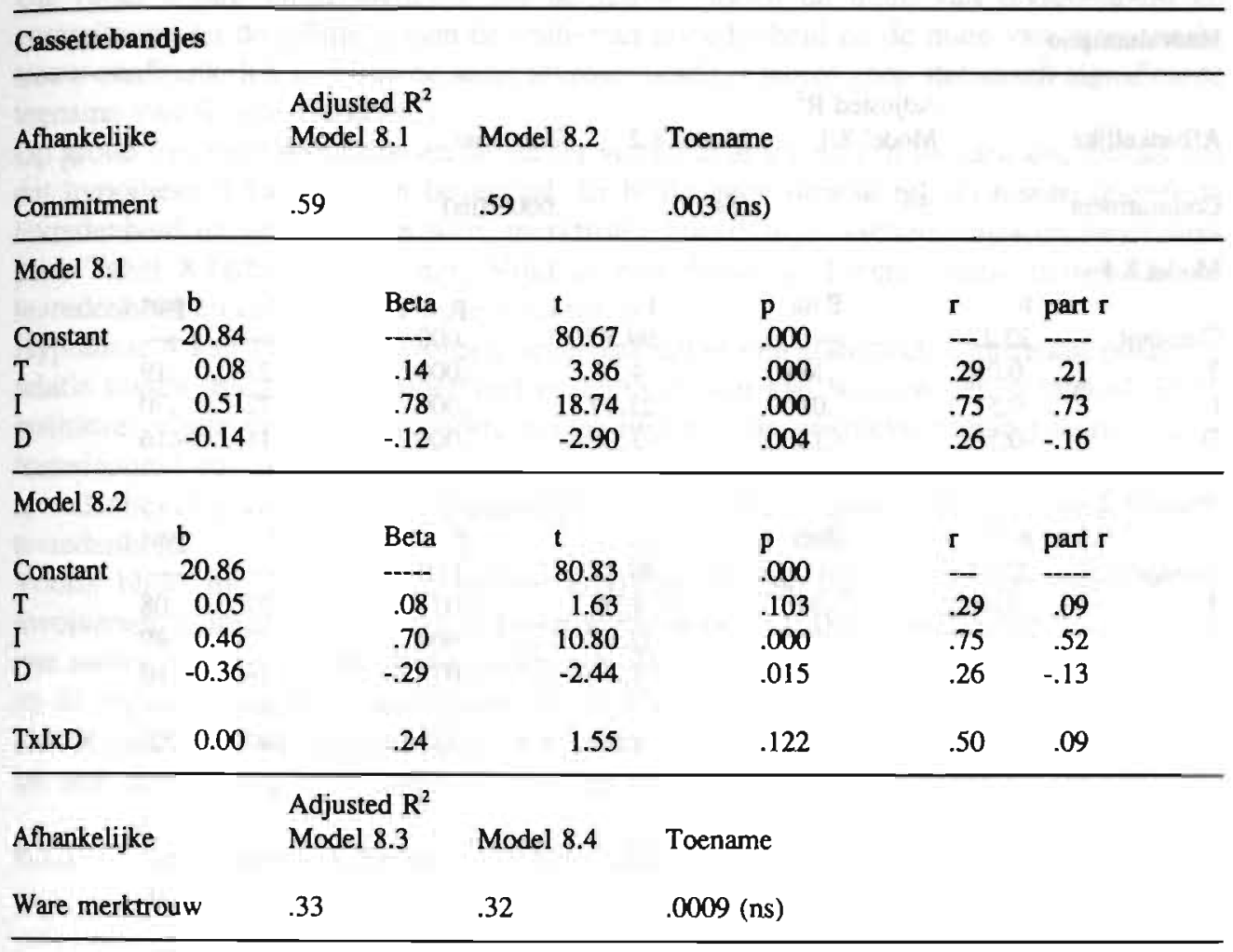

Model 8.3

\begin{tabular}{lllllll} 
& $\mathrm{b}$ & $\mathrm{B}$ & $\mathrm{t}$ & $\mathrm{p}$ & $\mathrm{r}$ & part $\mathrm{r}$ \\
Constant & 3.66 &.-- & 41.27 & .000 &.-- &.-- \\
$\mathrm{T}$ & 0.01 & .07 & 1.42 & .156 & .18 & .08 \\
$\mathrm{I}$ & 0.09 & .53 & 9.85 & .000 & .56 & .48 \\
$\mathrm{D}$ & 0.02 & .05 & 0.93 & .354 & .31 & .05 \\
\hline
\end{tabular}

\section{Model 8.4}

b

Constant

I

$\begin{array}{rr} & 0.08 \\ \text { D } & -0.02\end{array}$

3.66

0.00

$-0.02$

\begin{tabular}{rr} 
Beta & \multicolumn{1}{c}{$\mathrm{t}$} \\
-.03 & 41.25 \\
.48 & 0.48 \\
-.06 & 5.88 \\
\hline & -0.38
\end{tabular}

$\begin{array}{lll}\mathrm{p} & \mathrm{r} & \text { part } \mathrm{r} \\ .000 & -. & - \\ .625 & .18 & .03 \\ .000 & .56 & .31 \\ .703 & .31 & -.02\end{array}$

TxIxD

0.00

.15

0.74

.457

$.45 \quad .04$

\section{Legenda:}

b: partiële regressie coëfficiënt; Beta: gestandaardiseerde partiële regressie coëfficiënt; $t: t$ waarde voor $\mathrm{B}$; $\mathrm{p}$ : significantie niveau $\mathrm{t}$; $\mathrm{r}$ : Pearson correlatie coêfficiënt; part $\mathrm{r}$ : partiële correlatie coëfficiënt; $\mathrm{C}$ : commitment; MT: ware merktrouw; T: tevredenheid; I: merkkeuze-involvement; D: deliberatie; TxIxD: soort tevredenheid. 
Tabel 8.2b: Resultaten van de hiërarchische regressie-analyse: het effect van de soort tevredenheid op de relatie tussen de mate van tevredenheid en de afhankelijke variabele commitment en ware merktrouw bij haarshampoo

\section{Hearshampoo}

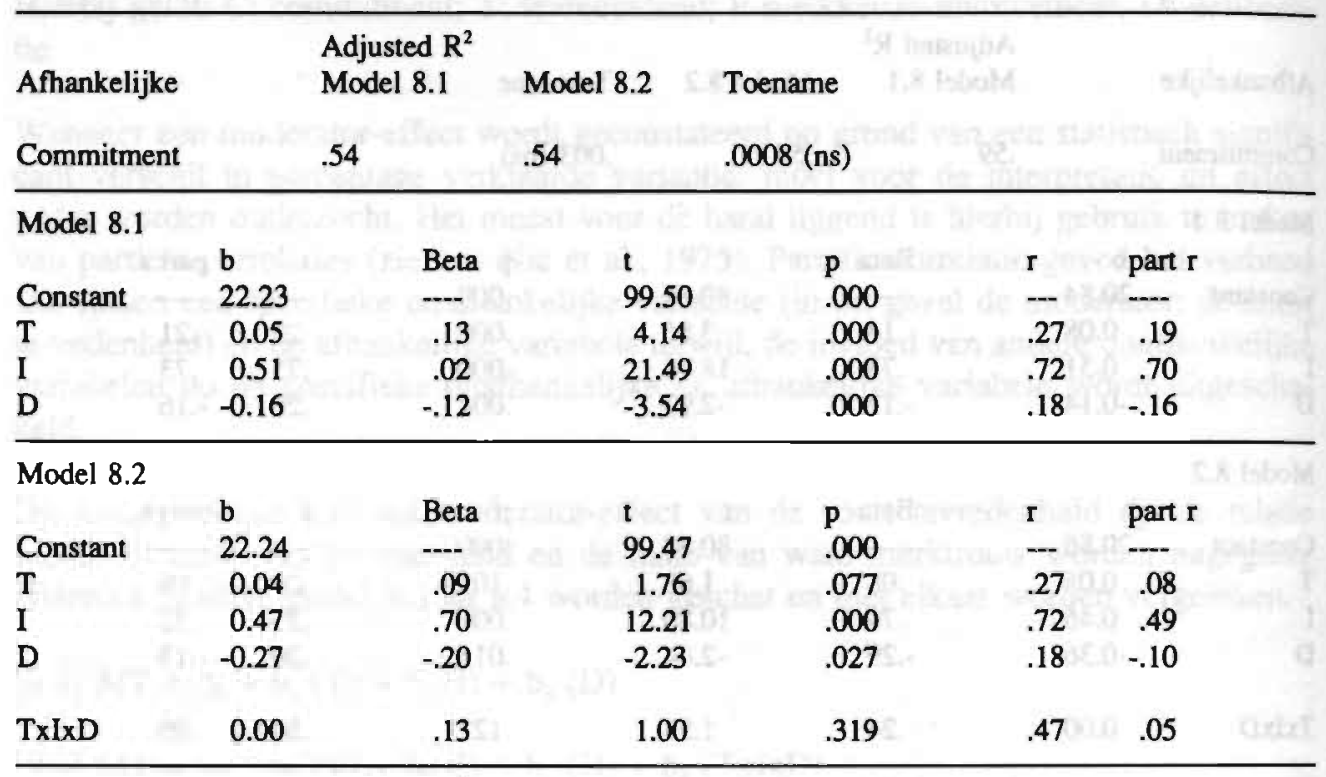

$\begin{array}{llll}\text { Afhankelijke } & \begin{array}{l}\text { Adjusted } \mathrm{R}^{2} \\ \text { Model 8.3 }\end{array} & \text { Model 8.4 } & \text { Toename } \\ \text { Ware merktrouw } & .26 & .26 & .003 \text { (ns) }\end{array}$

\begin{tabular}{|c|c|c|c|c|c|c|c|}
\hline \\
\hline Model 8.3 & b & Beta & $\mathrm{t}$ & $\mathrm{p}$ & $r$ & part $r$ & \\
\hline Constant & 4.03 & $\ldots$ & 50.66 & .000 & $\cdots$ & 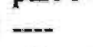 & \\
\hline $\mathrm{T}$ & 0.01 & .08 & 2.05 & .040 & .17 & .09 & $10=0$ \\
\hline 1 & 0.09 & .47 & 11.06 & .000 & .51 & .45 & \\
\hline D & 0.02 & .05 & 1.09 & .276 & .24 & .05 & \\
\hline \multicolumn{8}{|l|}{ Model 8.4} \\
\hline & $b$ & Beta & $t$ & $p$ & $\mathrm{r}$ & part $\mathbf{r}$ & $41+20.34$ \\
\hline Constant & 4.02 & - & 50.60 & .000 & $\ldots$ & - & \\
\hline $\mathrm{T}$ & 0.02 & .16 & 2.41 & .016 & .17 & .11 & inas: \\
\hline I & 0.11 & .56 & 7.84 & .000 & .51 & .33 & \\
\hline D & 0.09 & .20 & 1.76 & .078 & .24 & .08 & \\
\hline TxIxD & 0.00 & -.23 & -1.47 & .142 & .38 & -.06 & \\
\hline
\end{tabular}

Legenda:

b: partiële regressie coëfficiënt; Beta: gestandaardiseerde partiële regressie coëfficiënt; $t: t$ waarde voor B; p: significantie niveau t; r: Pearson correlatie coëfficiënt; part r: partiële correlatie coëfficiënt; $C$ : commitment; MT: ware merktrouw; T: tevredenheid; I: merkkeuze-involvement; D: deliberatie; TxIxD: soort tevredenheid. 
(Bij de schatting van de parameters is gebruik gemaakt van afwijkingsscores van de voorspellende variabelen.)

Uit Tabel $8.2 \mathrm{a} / \mathrm{b}$ blijkt duidelijk dat de relatie tussen de mate van tevredenheid en commitment en de relatie tussen de mate van tevredenheid en de mate van ware merktrouw onafhankelijk zijn van de soort tevredenheid (er wordt geen statistisch significante toename van $\mathbf{R}^{2}$ geconstateerd).

Op grond van deze resultaten en de eerder verrichte analyses kan worden geconcludeerd dat hypothese $3 \mathrm{kan}$ worden bevestigd. Er blijkt geen directe relatie tussen manifeste tevredenheid en de mate van ware merktrouw ( $r=.05$ bij cassettebandjes en haarshampoo; Tabel $8.1 \mathrm{a} / \mathrm{b}$ ). Net zo min blijkt er een duidelijk directe relatie tussen latente tevredenheid en de mate van ware merktrouw.

Hypothese 4 kan in zoverre worden bevestigd dat er een statistisch significant positieve relatie tussen manifeste tevredenheid en commitment kan worden geconstateerd. Deze positieve relatie verschilt in sterkte echter niet van de positieve relatie tussen latente tevredenheid en commitment. Hieruit moet geconcludeerd worden dat de mate waarin tevredenheid bijdraagt aan de verklaring van commitment onafhankelijk is van de soort tevredenheid.

Voorts blijkt uit Tabel $8.2 \mathrm{a} / \mathrm{b}$ dat de motivatie (geoperationaliseerd als merkkeuzeinvolvement) om de merkkeuze te beoordelen de belangrijkste verklarende variabele is van zowel commitment als ware merktrouw. De bijdrage van de mate van tevredenheid en de capaciteit (geoperationaliseerd als deliberatie) om de merkkeuze te beoordelen, aan de verklaring van commitment en ware merktrouw, is relatief gering. In het vervolg zal ook hieraan nog nader aandacht worden besteed.

\subsubsection{Alternatieve definitie en operationalisatie van ware merktrouw: loyaliteit (Model II)}

In het vorige hoofdstuk is reeds geconcludeerd dat het positieve verband tussen de mate van tevredenheid en commitment marginaal is. Tevens is vastgesteld dat commitment en de mate van ware merktrouw positief met elkaar samenhangen, al is het verband tussen beide variabelen niet volledig. Hieruit concluderen wij dat de mate van tevredenheid op zich nauwelijks van belang is bij de verklaring van ware merktrouw. De mate van tevredenheid draagt zoals verwacht niet direct bij aan de verklaring van ware merktrouw maar de mate van tevredenheid draagt, tegen de verwachting in, ook niet indirect via commitment bij aan de verklaring van ware merktrouw. Ook wanneer verschillende soorten tevredenheid worden onderscheiden verandert dit niets aan de bijdrage van tevredenheid aan de verklaring van ware merktrouw.

Uit de bivariate analyses in het vorige hoofdstuk is verder naar voren gekomen dat tevredenheid sterker samenhangt met de kans op een herhalingsaankoop dan met de mate van ware merktrouw. Ook blijkt commitment niet alleen duidelijk positief samen te hangen met de mate van ware merktrouw maar blijkt commitment nagenoeg in dezelfde mate positief samen te hangen met de kans op een herhalingsaankoop.

Omdat deze bevindingen niet overeenkomstig onze verwachtingen zijn, willen wij nader aandacht besteden aan onze definitie van ware merktrouw, het onderzoeksmodel met de bijbehorende definities en de operationalisatie van ware merktrouw. 
Ware merktrouw is tot nu toe gedefinieerd als 'the biased behavioral response etc.' Commitment is hierbij opgevat als een noodzakelijke voorwaarde voor ware merktrouw. Commitment maakt geen deel uit van de definitie van ware merktrouw. Onze bevindingen tot nu toe, nopen ons, onze oorspronkelijke definitie aan te passen en commitment in de definitie op te nemen. Commitment is hierdoor niet langer een onafhankelijke variabele die bijdraagt aan de verklaring van ware merktrouw. Commitment gaat hierdoor deel uit maken van de afhankelijke variabele (ware merktrouw). Ware merktrouw wordt hierdoor, meer dan voorheen, een concept dat is opgebouwd uit zowel gedragsals psychologische aspecten. Bovendien wordt het psychologische aspect, zijnde commitment, nadrukkelijk ingevuld.

Wij stellen voor onze oorspronkelijke defintie van ware merktrouw aan te passen. Ware merktrouw wordt nu gedefiniëerd als:

The biased (i.e.) nonrandom, behavioral response (i.e. purchase), expressed over time, by some decision making unit, with respect to one or more alternative brands out of a set of such brands, and is a function of brand commitment, which, in turn, is a result of psychological (decision making, evaluative) processes.

Ons onderzoeksmodel moet hierdoor worden aangepast (zie Figuur 8.1a t/m c). Commitment is niet langer een interveniërende variabele in de relatie tussen tevredenheid en de afhankelijke variabele (ware merktrouw). Bij de verklaring van ware merktrouw maakt commitment deel uit van de afhankelijke variabele zodat een directe relatie tussen tevredenheid en de mate van ware merktrouw wordt gespecificeerd. Wij verwachten dat de mate waarin tevredenheid direct bijdraagt aan de verklaring van ware merktrouw afhankelijk is van de soort tevredenheid: manifeste tevredenheid zal sterker gerelateerd zijn aan ware merktrouw dan latente tevredenheid.

Figuur 8.1a: Aangepast algemeen Model (II) van de relatie tussen merktrouw en tevredenheid

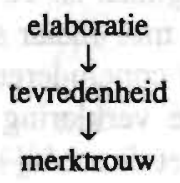

Figuur 8.1a wordt vervolgens nader gespecificeerd voor ware merktrouw (Figuur 8.1b) en voor herhalingsaankopen (Figuur 8.1c).

Figuur 8.1b: Model II van de relatie tussen ware merktrouw en tevredenheid

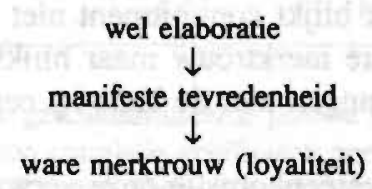


Figuur 8.1c: Model II van de relatie tussen herhalingsaankopen en tevredenheid

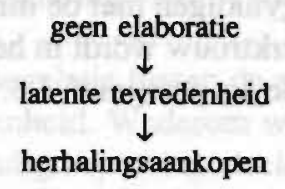

Onze oorspronkelijke hypothesen moeten hierdoor eveneens worden aangepast c.q aangevuld en luiden nu (hierbij is zoveel mogelijk de oorspronkelijke nummering gehandhaafd; aanpassingen zijn vet):

1 Tussen de mate van tevredenheid en ware merktrouw bestaat wel een directe relatie.

3 Tussen manifeste tevredenheid en ware merktrouw bestaat wel een directe relatie.

4 Manifeste tevredenheid leidt tot ware merktrouw.

Bovendien wordt een hypothese toegevoegd:

6 De positieve directe relatie tussen manifeste tevredenheid en ware merktrouw is sterker dan de positieve directe relatie tussen latente tevredenheid en ware merktrouw.

Bij deze hypothesen wordt de volgende assumptie gehanteerd:

Naarmate de mate van elaboratie toeneemt (dat wil zeggen naarmate merkeuze-involvement en deliberatie groter zijn), is de tevredenheid meer manifest.

(Hypothese 2 en hypothese 5 zijn als gevolg van de aanpassing van de operationalisatie van de afhankelijke variabele vervallen.)

Door deze aanpassing van de definitie van ware merktrouw en het mede op deze definitie gebaseerde onderzoeksmodel met bijbehorende hypothesen moet ook de operationalisatie van ware merktrouw en het onderzoeksmodel worden aangepast.

In aansluiting op de oorspronkelijke definitie en het bijbehorende onderzoeksmodel is ware merktrouw geoperationaliseerd als de manier waarop een merk opnieuw wordt gekocht. Deze maat houdt niet nadrukkelijk rekening met de commitment van een consument omdat commitment geen deel uitmaakte van de oorspronkelijke definitie van ware merktrouw. Bovendien werd er bij deze maat impliciet vanuit gegaan dat een consument een produkt opnieuw zal kopen. Dat wil zeggen dat er niet nadrukkelijk rekening wordt gehouden met de mogelijkheid dat een consument een ander merk koopt.

Wij stellen daarom een nieuwe operationalisatie van ware merktrouw voor. Een gecombineerde maat (vergelijk paragraaf 1.3.2) waarin zowel het aan ware merktrouw ten grondslag liggende psychologische construct van commitment is vertegenwoordigd als het gedragsaspect van het al dan niet opnieuw kopen van hetzelfde merk. 
De gecombineerde maat van ware merktrouw wordt geoperationaliseerd door de kans op een herhalingsaankoop te vermenigvuldigen met de mate van commitment. Deze alternatieve operationalisatie van ware merktrouw wordt in het vervolg aangeduid met loyaliteit (deze maat staat geheel los van de in paragraaf 1.3.2 genoemde loyaliteits-index van Day (1969)).

De aangepaste hypothesen zullen getoetst worden met behulp van het bestaande datamateriaal. Wij realiseren ons dat er - onderzoeks-technisch gezien - mogelijk een gevaar bestaat dat de hypothesen onterecht worden geaccepteerd. Derhalve zullen de resultaten van de volgende analyses met enige voorzichtigheid moeten worden geïnterpreteerd.

Wij willen met deze toetsing desalniettemin nagaan of de nieuwe inzichten, die verkregen zijn na een eerste grondige analyse van het data materiaal, bevestigd kunnen worden omdat hieruit toch een indicatie omtrent de geldigheid van de nieuwe opzet kan worden verkregen.

De voorlopige resultaten van een nieuwe 'derde' case studie (interne notitie) geven echter aan dat de 'nieuwe opzet' tot verantwoorde conclusies leidt. Dit maakt onze reserves ten aanzien van de nu volgende conclusies minder groot.

In het vervolg van dit hoofdstuk zal de operationalisatie van ware merktrouw in termen van loyaliteit centraal staan. Loyaliteit wordt geoperationaliseerd als het produkt van de kans op een herhalingsaankoop vermenigvuldigd met de mate van commitment per respondent. (Dit omdat een interactie-effect tussen de kans op een herhalingsaankoop en commitment wordt verondersteld.) Tabel 8.3 geeft een overzicht van de gemiddelde loyaliteitsscores voor de twee produkten. (De minimale loyaliteitsscore bedraagt theoretisch 6 bij minimale commitment en geen kans op herhalingsaankoop; de maximale loyaliteitsscore bedraagt theoretisch 330 bij maximale commitment en $100 \%$ kans op een herhalingsaankoop.)

Tabel 8.3: Overzicht gemiddelden en standaarddeviatie van loyaliteit bij cassettebandjes en haarshampoo

\begin{tabular}{lll}
\hline & Gemiddelde & Standaarddeviatie \\
\hline & loyaliteit & \\
cassettebandjes & 189 & 99 \\
haarshampoo & 204 & 100 \\
\hline
\end{tabular}

Om na te gaan of er een directe relatie bestaat tussen de mate van tevredenheid en loyaliteit wordt allereerst de correlatie-coëfficiënt tussen beide variabelen berekend. (Alle tevreden respondenten worden in de analyse opgenomen; dus worden respondenten die te kennen hebben gegeven 'voortdurend van merk te wisselen' niet langer buiten beschouwing gelaten.) De correlatie-coëfficiënt de mate van tevredenheid en loyaliteit bedraagt .37 bij cassettebandjes en .42 bij haarshampoo (voor beide geldt $p<.001$ ). Er blijkt dus een direct verband te bestaan tussen de mate van tevredenheid en de mate van gecombineerde ware merktrouw, hoewel dit verband verre van perfect is. Onze aange- 
paste hypothese 1 wordt hierdoor ondersteund. Dit duidt erop dat mogelijk nog andere factoren van invloed zijn op de verklaring van loyaliteit.

Vervolgens wordt onderzocht of de relatie tussen de mate van tevredenheid en loyaliteit afhankelijk is van de soort tevredenheid. Wederom wordt de totale groep respondenten, zoals in paragraaf 8.2.1 in twee subgroepen ingedeeld. Voor beide subgroepen worden de correlatie-coëfficiënt tussen de mate van tevredenheid en loyaliteit berekend. Of er een statistisch significant verschil tussen de coëfficiënten van de subgroepen bestaat, wordt getoetst met de Fisher Z-toets. De resultaten van deze analyse staan vermeld in Tabel $8.4 \mathrm{a} / \mathrm{b}$.

Tabel 8.4a: Correlatie tussen tevredenheid (T) en loyaliteit (LOY) bij latente en manifeste tevredenheid voor cassettebandjes

Cassettebandjes

Respondenten

latente tevredenheid

manifeste tevredenheid

Fisher Z

$*: p<.05 ; * *: p<.001$

Tabel 8.4b: Correlatie tussen tevredenheid (T) en loyaliteit (LOY) bij latente en manifeste tevredenheid voor haarshampoo

Haarshampoo

Respondenten

latente tevredenheid

manifeste tevredenheid

Fisher Z

$*: p<.05 ; * * ; p<.001$

Uit Tabel $8.4 \mathrm{a} / \mathrm{b}$ blijkt dat de relatie tussen de mate van tevredenheid en loyaliteit afhankelijk is van de soort tevredenheid (Fisher $\mathrm{Z}$ is statistisch significant). Dit betekent dat het verschil maakt of respondenten manifest of latent tevreden zijn voor wat betreft de relatie tussen de mate van tevredenheid en loyaliteit. Bij manifest tevreden respondenten blijkt de relatie tussen de mate van tevredenheid en loyaliteit (statistisch significant) sterker dan bij latent tevreden respondenten.

Omdat bij de indeling van de respondenten naar soort tevredenheid (latent of manifest) gebruik is gemaakt van een min of meer 'willekeurige' indeling, wordt het moderatoreffect van de soort tevredenheid nader onderzocht. Dit gebeurt wederom met behulp van hiërarchische regressie-analyse, zoals reeds beschreven in paragraaf 8.2.1. De volgende modellen moeten geschat worden: 
[8.5] LOY $=b_{0}+b_{1}(T)+b_{2}(I)+b_{3}$ (D)

[8.6] LOY $=b_{0}+b_{1}(T)+b_{2}(I)+b_{3}(D)+b_{4}(T x I x D)$

Hierbij geldt: LOY: loyaliteit; T: tevredenheid; I: merkeuze-involvement; D: deliberatie

De resultaten van deze analyse staan weergegeven in Tabel $8.5 \mathrm{a} / \mathrm{b}$.

Tabel 8.5a: Resultaten van de hiërarchische regressie-analyse: het effect van de soort tevredenheid op de relatie tussen de mate van tevredenheid en de afhankelijke variabele loyaliteit bij cassettebandjes

\section{Cassettebandjes}

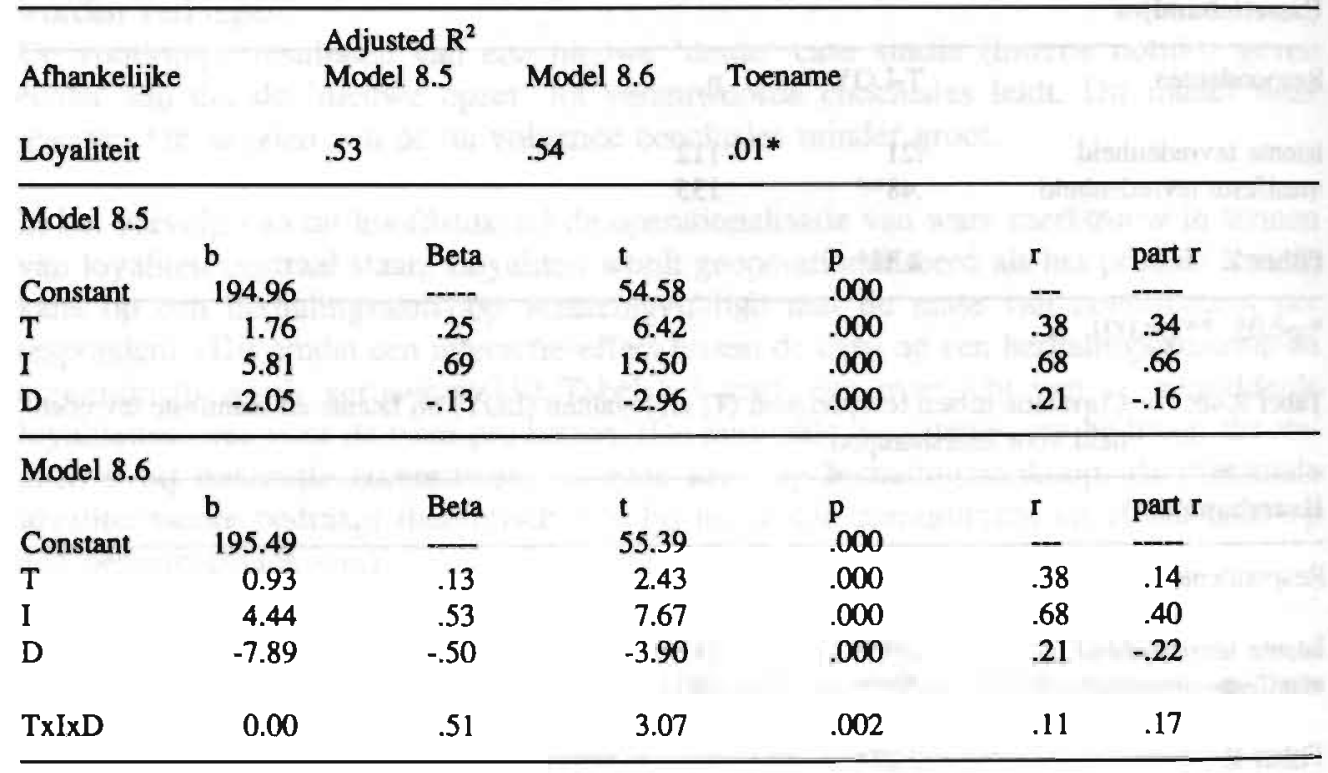

Legenda:

B: partiěle regressie coëfficiënt; Beta: gestandaardiseerde partiële regressie coëfficiënt; $t: t$ waarde voor B; p: significantie niveau $t$; r: Pearson correlatie coëfficiënt; part r: partiële correlatie coëfficiënt; LOY: loyaliteit; T: tevredenheid; I: merkeuze-involvement; D: deliberatie; TxIxD: soort tevredenheid. 
Tabel 8.5b: Resultaten van de hiërarchische regressie-analyse: het effect van de soort tevredenheid op de relatie tussen de mate van tevredenheid en de afhankelijke variabele loyaliteit bij haarshampoo

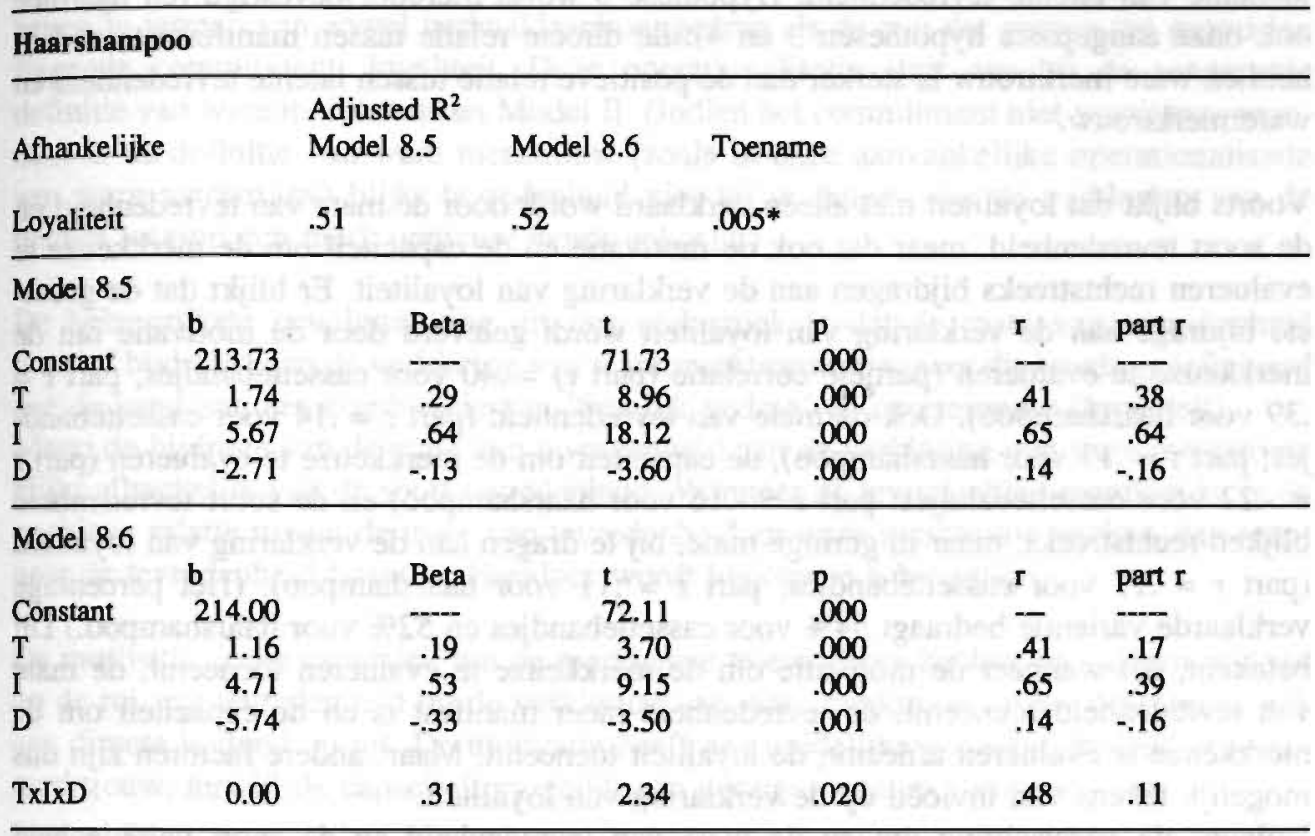

Legenda:

B: partiële regressie coëfficiënt; Beta: gestandaardiseerde partiële regressie coëfficiënt; $t: t$ waarde voor B; p: significantie niveau t; r: Pearson correlatie coëfficiënt; part r: partiële correlatie coëfficiënt; LOY: loyaliteit; T: tevredenheid; I: merkeuze-involvement; D: deliberatie; TxIxD: soort tevredenheid.

Uit Tabel $8.5 \mathrm{a} / \mathrm{b}$ blijkt duidelijk dat de relatie tussen de mate van tevredenheid en loyaliteit afhankelijk is van de soort tevredenheid (er wordt een statistisch significante toename van $\mathbf{R}^{2}$ geconstateerd).

Hoewel nu geconstateerd is dat er een statistisch significant moderator-effect aanwezig is van de soort tevredenheid op de relatie tussen de mate van tevredenheid en loyaliteit, blijkt eveneens dat de omvang van dit effect klein is. Daarnaast is er echter nog geen inzicht in de richting en de sterkte van dit effect. In het vervolg wordt hieraan aandacht besteed.

Om inzicht te krijgen in de sterkte en de richting van de geconstateerde moderatoreffecten, worden eveneens in Tabel $8.5 \mathrm{a} / \mathrm{b}$ de parameters van de variabelen in de hiërarchische regressie gepresenteerd.

Het moderator-effect van de soort tevredenheid op de relatie tussen de mate van tevredenheid en loyaliteit blijkt zowel voor cassettebandjes als haarshampoo positief te zijn; de partiële correlaties van de moderator-effecten variëren bedragen respectievelijk .17 en .11 (voor beide geldt $p<.05$ ) voor cassettebandjes en haarshampoo.

Hieruit moet geconcludeerd worden dat de relatie tussen de mate van tevredenheid en loyaliteit sterker is wanneer de consument manifest tevreden is, dan wanneer de consu- 
ment latent tevreden is. Met andere woorden: de invloed van een toename van manifeste tevredenheid op de mate van ware merktrouw is groter dan de invloed van een zelfde toename van latente tevredenheid. Hypothese 6 wordt hierdoor bevestigd (en daarmee ook onze aangepaste hypothesen 3 en 4): de directe relatie tussen manifeste tevredenheid en ware merktrouw is sterker dan de positieve relatie tussen latente tevredenheid en ware merktrouw.

Voorts blijkt dat loyaliteit niet alleen verklaard wordt door de mate van tevredenheid en de soort tevredenheid, maar dat ook de motivatie en de capaciteit om de merkkeuze te evalueren rechtstreeks bijdragen aan de verklaring van loyaliteit. Er blijkt dat de grootste bijdrage aan de verklaring van loyaliteit wordt geleverd door de motivatie om de merkkeuze te evalueren (partiële correlatie (part $r$ ) $=.40$ voor cassettebandjes; part $r=$ .39 voor haarshampoo). Ook de mate van tevredenheid ( $p a r t r=.14$ voor cassettebandjes; part $r=.17$ voor haarshampoo), de capaciteit om de merkkeuze te evalueren (part $r$ $=-.22$ voor cassettebandjes; part $r=-.16$ voor haarshampoo) en de soort tevredenheid blijken rechtstreeks, maar in geringe mate, bij te dragen aan de verklaring van loyaliteit (part $\mathrm{r}=.17$ voor cassettebandjes; part $\mathrm{r}=.11$ voor haarshampoo). (Het percentage verklaarde variantie bedraagt $54 \%$ voor cassettebandjes en $52 \%$ voor haarshampoo.) Dit betekent, dat wanneer de motivatie om de merkkeuze te evalueren toeneemt, de mate van tevredenheid toeneemt, de tevredenheid meer manifest is en de capaciteit om de merkkeuze te evalueren afneemt, de loyaliteit toeneemt. Maar: andere factoren zijn dus mogelijk tevens van invloed op de verklaring van loyaliteit.

Volgens de verwachting dragen de mate van tevredenheid en de soort tevredenheid direct en positief bij aan de verklaring van loyaliteit. Al moet gecnstateerd worden dat de bijdrage van zowel de mate van tevredenheid als de soort tevredenheid gering is. Desalniettemin blijkt dat merkkeuze-gedrag waarover een consument meer tevreden is, wordt gemakkelijker herhaald dan merkkeuze-gedrag waarover een consument minder tevreden is. En des te uitgebreider de merkkeuze is geëvalueerd en/of des te manifester het tevredenheidsoordeel en/of des te duidelijker de invloed van dit oordeel op het (koop)gedrag van de consument in de toekomst; des te groter de loyaliteit.

Ook de motivatie om de merkkeuze te evalueren blijkt direct en positief bij te dragen aan de verklaring van loyaliteit. Consumenten die gemotiveerd zijn om de merkkeuze te evalueren, zullen ook gemotiveerd zijn een 'juiste' merkkeuze te maken. Des te zorgvuldiger de merkkeuze tot stand is gekomen, des te groter is ook de kans dat de oorspronkelijke keuze gehandhaafd zal blijven in de toekomst.

Het niet verwachte negatieve effect van deliberatie zou echter kunnen worden geïnterpreteerd door te vooronderstellen dat hoe groter de capaciteit van consumenten is om over de merkkeuze na te denken, hoe gemakkelijker zij daarbij ook andere merken in overweging zullen nemen. Dit zal leiden tot een daling van de loyaliteit. Het effect van deliberatie op loyaliteit verdient evenwel een nadere analyse voordat definitieve conclusies kunnen worden getrokken. 


\subsection{Conclusie}

De conclusies in deze paragraaf zijn gebaseerd op een operationalisatie van ware merktrouw in termen van zowel herhaaldaankoopgedrag als de aan dat gedrag ten grondslag liggende commitment: loyaliteit. Deze operationalisatie sluit aan bij de aangepaste definitie van ware merktrouw en Model II. (Indien het commitment niet wordt meegenomen in de definitie van ware merktrouw (zoals in onze aanvankelijke operationalisatie van ware merktrouw) blijkt tevredenheid niet bij te dragen aan de verklaring van de manier waarop een merk opnieuw wordt gekocht.)

De belangrijkste gevolgtrekking uit ons onderzoek is dat de mate van tevredenheid positief bijdraagt aan de verklaring van ware merktrouw, wanneer dit wordt gedefinieerd aan de hand van een combinatie van 'feitelijk gedrag' en commitment (loyaliteit). Maar: de bijdrage van de mate van tevredenheid aan de verklaring van ware merktrouw blijkt afhankelijk van de soort tevredenheid. Wanneer de tevredenheid manifest is, is de positieve relatie tussen de mate van tevredenheid en ware merktrouw sterker, dan wanneer de tevredenheid latent is. Hierdoor wordt hypothese 6 bevestigd.

De motivatie en de capaciteit om de merkkeuze te evalueren hebben niet alleen invloed op de rol van tevredenheid bij de verklaring van ware merktrouw, maar oefenen er ook een directe invloed op uit. De motivatie heeft een duidelijke positieve invloed op ware merktrouw, terwijl de capaciteit mogelijk een geringe negatieve invloed heeft. 


\section{Conclusies en implicaties van het onderzoek}

\subsection{Conclusies}

\subsubsection{Definities, modellen en operationalisatie}

Bij de analyse van de resultaten van ons onderzoek naar de rol die tevredenheid speelt bij de verklaring van ware merktrouw, is gebleken dat er een onderscheid moet worden gemaakt tussen twee verschillende definities van ware merktrouw (met bijbehorende onderzoeksmodellen en operationalisaties).

Ware merktrouw is aanvankelijk door ons gedefinieerd als: "the biased behavioral response, expressed over time, by some decision making unit, with respect to one or more alternative brands out of a set of such brands, and is a function of psychological processes".

In aansluiting op deze definitie is Model I geformuleerd, waarin commitment een onafhankelijke variabele is. Commitment wordt beschouwd als een noodzakelijke voorwaarde voor ware merktrouw, maar maakt geen deel uit van ware merktrouw. Ware merktrouw is aanvankelijk geoperationaliseerd als een beschrijving van de manier waarop een merk opnieuw wordt gekocht, ervan uitgaande dat het merk opnieuw wordt gekocht (de mate van ware merktrouw).

Tevredenheid en ware merktrouw blijken, uitgaande van deze definitie, tegen de verwachting in, nauwelijks aan elkaar gerelateerd te zijn. Dit heeft ons doen besluiten onze aanvankelijke definitie van ware merktrouw te heroverwegen. Commitment kan ook worden opgevat als een onderdeel van ware merktrouw. Dit betekent dat commitment in de definitie van ware merktrouw wordt opgenomen en niet langer een interveniërende variabele is in de relatie tussen tevredenheid en ware merktrouw. Ware merktrouw wordt dan gedefinieerd als: "the biased behavioral response, expressed over time, by some decision making unit, with respect to one or more alternative brands out of a set of such brands, and is a function of brand commitment, which is, in turn, a result of psychological processes".

In aansluiting op deze definitie is Model II geformuleerd en getoetst. Ware merktrouw is geoperationaliseerd in termen van zowel commitment als feitelijk (koop)gedrag. Deze altematieve operationalisatie van ware merktrouw hebben wij loyaliteit genoemd. Tevredenheid en loyaliteit blijken nu, meer overeenkomstig onze inzichten aan elkaar gerelateerd te zijn. De soort tevredenheid (manifest of latent) blijkt, eveneens overeenkomstig onze eerdere verwachtingen, een rol bij de verklaring van loyaliteit te spelen. 
Met name deze bevindingen zijn voor ons aanleiding te concluderen, dat onze aanvankelijke definitie van ware merktrouw te beperkt is geweest. Het is achteraf beter gebleken ware merktrouw zowel in termen van gedrag als in termen van commitment te definieren. Wanneer de resultaten van ons onderzoek in het vervolg van dit hoofdstuk nader worden besproken, zal daarom uitgegaan worden van de aangepaste definitie van ware merktrouw. Hierbij is ware merktrouw geoperationaliseerd als loyaliteit.

\subsubsection{Hypothesen}

Omdat ware merktrouw in tweede instantie wordt gedefinieerd in termen van zowel gedrag als commitment kan niet langer een onderscheid worden gemaakt tussen commitment en ware merktrouw. Onze aanvankelijke hypothesen zijn daarom aangepast en luiden nu:

1 Tussen de mate van tevredenheid en ware merktrouw bestaat wel een directe relatie.

3 Tussen manifeste tevredenheid en ware merktrouw bestaat een wel directe relatie.

4 Manifeste tevredenheid leidt tot ware merktrouw.

Bovendien wordt een hypothese toegevoegd:

6 De positieve directe relatie tussen manifeste tevredenheid en ware merktrouw is sterker dan de positieve directe relatie tussen latente tevredenheid en ware merktrouw.

Bij deze hypothesen wordt de volgende assumptie gehanteerd:

Naarmate de mate van elaboratie toeneemt (dat wil zeggen naarmate involvement en deliberatie groter zijn), is de tevredenheid meer manifest.

(Hypothese 2 en hypothese 5 zijn als gevolg van de aanpassing van de operationalisatie van de afhankelijke variabele vervallen.)

Hypothese 1 wordt bevestigd door de positieve correlatie tussen de mate van tevredenheid en loyaliteit. Hypothese 3 en hypothese 4 worden bevestigd door de positieve correlatie tussen manifeste tevredenheid en loyaliteit. Hypothese 6 wordt bevestigd doordat met behulp van hiërarchische regressie wordt aangetoond dat de relatie tussen de mate van tevredenheid en loyaliteit afhankelijk is van de soort tevredenheid. De positieve relatie tussen manifeste tevredenheid en loyaliteit is sterker dan de positieve relatie tussen latente tevredenheid en loyaliteit.

\subsubsection{Terug naar de probleemstelling en de doelstelling}

De door ons in de inleiding, geformuleerde probleemstelling luidde: "Welke rol speelt tevredenheid bij de verklaring van ware merktrouw?" 
Uit ons onderzoek is gebleken dat deze probleemstelling alleen duidelijk beantwoord kan worden wanneer deze toegespitst wordt op onze aangepaste definiëring van ware merktrouw, welke vervolgens is geoperationaliseerd als loyaliteit: bij een toename van de tevredenheid, neemt de ware merktrouw van de consument toe. Deze toename is des te sterker wanneer de tevredenheid meer manifest is, doordat een uitgebreide evaluatie van het merk heeft plaatsgevonden. Latente tevredenheid daarentegen, houdt (meestal) niet meer in dan simpele acceptatie van het merk. Toename van latente tevredenheid is dan ook minder sterk gerelateerd aan ware merktrouw dan toename van manifeste tevredenheid. Met andere woorden: de invloed van de toename van manifeste tevredenheid op ware merktrouw is groter dan de invloed van een zelfde toename van latente tevredenheid.

Maar ons onderzoek toont ook aan, dat ware merktrouw niet alleén gerelateerd is aan de mate en de soort tevredenheid. Dat brengt ons terug bij de doelstelling van ons onderzoek die wij in de inleiding nader formuleerden als "inzicht te verkrijgen in de verklaring van ware merktrouw en daarbij vast te stellen welke rol tevredenheid en eventuele andere factoren spelen bij die verklaring". Deze doelstelling is dus breder dan uit de hiervoor, zeer kort geformuleerde probleemstelling zou kunnen worden afgeleid.

Wij tonen in het kader van deze doelstelling aan dat de motivatie en de capaciteit van de consument om de merkkeuze te evalueren ook direct gerelateerd zijn aan ware merktrouw. Naarmate de motivatie van de consument groter is om de merkkeuze te evalueren blijkt ware merktrouw duidelijk toe te nemen. Deze ware merktrouw lijkt daarentegen iets af te nemen, naarmate de consument over een grotere capaciteit beschikt om de merkkeuze te evalueren.

Samengevat kan gesteld worden dat de ware merktrouw (geoperationaliseerd als loyaliteit) van een consument aan een merk in positieve zin samenhangt met:

1 de motivatie van de consument de merkkeuze te evalueren;

2 de mate van tevredenheid van die consument met de merkkeuze; en waarschijnlijk in negatieve zin samenhangt met:

3 de capaciteit van de consument om de merkkeuze te evalueren.

Hierbij moet worden aangetekend dat de positieve bijdrage van de mate van tevredenheid van de consument met de merkkeuze groter is wanneer de tevredenheid manifest is, dan wanneer de tevredenheid latent is.

Anders geformuleerd: De ware merktrouw zal groter zijn des te gemotiveerder de tevreden consument om de merkkeuze te evalueren en/of des te groter de mate van tevredenheid en/of des te uitgebreider het merk is geëvalueerd en/of des te geringer de capaciteit om de merkkeuze te evalueren. (Wanneer de motivatie van de tevreden consument om de merkkeuze te evalueren daalt en/of de mate van tevredenheid daalt en/of het merk minder uitgebreid wordt geëvalueerd en/of de capaciteit om de merkkeuze te evalueren toeneemt, daalt de ware merktrouw.) Van de vier genoemde factoren blijkt de motivatie 
van de consument om de merkkeuze te evalueren, het sterkst gerelateerd te zijn aan ware merktrouw. De soort tevredenheid en de capaciteit om de merkkeuze te evalueren zijn het minst sterk gerelateerd aan ware merktrouw.

\subsection{Aanbevelingen}

\subsubsection{Theoretische aanbevelingen}

In paragraaf 3.2 is op basis van de theorie een continuüm geconstrueerd voor de mate van merktrouw. De extreme posities op dit continuüm waren herhalingsaankopen en ware merktrouw. Er werd van uitgegaan dat het gedrag een 'gegeven' was: het herhaald kopen van een merk en dat commitment een noodzakelijke voorwaarde is voor ware merktrouw. Het continuüm is geconstrueerd om de twee soorten merktrouw duidelijker in kaart te kunnen brengen.

Het onderzoek heeft aangetoond dat het continuüm een goed uitgangspunt is bij de bestudering van de relatie tussen tevredenheid en ware merktrouw. Er is echter gebleken dat ware merktrouw het beste kan worden gedefinieerd in termen van zowel gedrag als commitment. Dit betekent dat commitment niet langer een onafhankelijke variabele is in de relatie tussen tevredenheid en ware merktrouw, maar deel uitmaakt van de afhankelijke variabele (ware merktrouw). Visueel kan dit als volgt worden weergegeven (Figuur 9.1):

Figuur 9.1: Aangepast continuüm van herhalingsaankopen tot ware merktrouw

$\begin{array}{cc}\text { geen commitment (inertia) } & \text { volledige commitment } \\ \text { én herhaalde aankoop } & \text { en herhaalde aankoop } \\ = & = \\ \text { herhalingsaankopen } & \text { ware merktrouw } \\ (=\text { loyaliteit })\end{array}$

Tevens heeft ons onderzoek aangetoond dat het belangrijk is een onderscheid te maken tussen twee soorten tevredenheid: manifeste tevredenheid en latente tevredenheid. Immers, de sterkte van de relatie tussen manifeste tevredenheid en ware merktrouw verschilt van de sterkte van de relatie tussen latente tevredenheid en ware merktrouw.

Tot nu toe wordt in de theorie over tevredenheid met name aandacht besteed aan de mate van tevredenheid. Slechts sporadisch wordt gewezen op het belang van het onderscheid tussen verschillende soorten tevredenheid (bijvoorbeeld Oliver, 1989). Het onderscheid tussen manifeste- en latente tevredenheid wordt in de literatuur nog niet aangetroffen. Het door ons aangebrachte onderscheid zal naar verwachting niet alleen implicaties hebben voor de theorie betreffende de relatie tussen ware merktrouw en tevredenheid. Bij de hele verdere theorie ontwikkeling omtrent tevredenheid zal er rekening mee moeten worden gehouden. 


\subsubsection{Management aanbevelingen}

ledere aanbieder van een merk is geïnteresseerd in ware merktrouw omdat ware merktrouw, meer nog dan herhalingsaankopen, één van de garanties is voor de continuitteit van de onderneming van de aanbieder.

Zowel de mate als de soort van tevredenheid blijken belangrijk te zijn bij het bewerkstelligen van ware merktrouw. De motivatie en de capaciteit om de merkkeuze te evalueren dragen tevens bij aan het ontstaan van ware merktrouw.

Iedere aanbieder die streeft naar ware merktrouw probeert dus te bereiken dat de consument:

- zo gemotiveerd mogelijk is;

- optimaal tevreden is, en

- het merk zo uitgebreid mogelijk evalueert.

Met elk van deze factoren moet een aanbieder dus rekening houden om zijn doel te verwezenlijken.

Allereerst zal worden besproken welke instrumenten een aanbieder kan aanwenden om de motivatie van een consument om de merkkeuze te evalueren, te beïnvloeden. Vervolgens zal worden geïnventariseerd hoe de mate van tevredenheid van een consument met een merk kan worden beïnvloed en daama zal worden aangeven hoe de mate van evaluatie van een merk kan worden gestuurd, waardoor de tevredenheid meer manifest wordt.

(Uit het onderzoek is gebleken dat naarmate de capaciteit van de consument om de merkkeuze te evalueren afneemt, de ware merktrouw iets stijgt. Dit zou betekenen dat een aanbieder er naar moet streven dat de capaciteit van de consument om de merkkeuze te evalueren gering is. Dit is ons inziens geen reële optie. In de eerste plaats omdat dit het uitgebreid evalueren van een merk is de weg staat en dus het ontstaan van manifeste tevredenheid. In de tweede plaats omdat dit zou kunnen leiden tot 'een consument is des te tevredener naarmate deze minder weet' (vergelijk Olander, 1977).

\section{Motivatie}

De motivatie van een consument om de merkkeuze te evalueren neemt toe, indien de algemene interesse of de betrokkenheid van die consument bij de merkkeuze toeneemt. De volgende strategieën kunnen leiden tot een vergroting van de motivatie om de merkkeuze te evalueren (Assael, 1992).

\section{Verbinden van het merk met een voor de doelgroep belangrijk onderwerp}

Deze strategie richt zich op het vergroten van de 'latitude of rejection' van concurrerende merken (Rothschild en Houston, 1986), waardoor deze concurrerende merken minder of onacceptabel worden voor de consument. Dit kan door het eigen merk in verband te brengen met een belangrijk onderwerp waarmee het merk van de concurrent niet in 
verband wordt gebracht. Bijvoorbeeld het gebruik van een zekere haarshampoo draagt bij aan een beter milieu; deze margarine is lekker én werkt cholesterolverlagend.

\section{Verbinden van het merk met een voor de consument belangrijke persoonlijke situatie}

Een andere manier om de motivatie van een consument te beïnvloeden is het merk in verband brengen met een persoonlijk relevante situatie of een activiteit waar de consument bijzonder in geïnteresseerd is (Tyebee, 1979). Voorbeelden zijn de commercial van 'het moment voor koffie' die s'ochtends op precies het goede tijdstip wordt uitgezonden en de reclame voor aspirine die net voor de komst van het bezoek op de consument met hoofdpijn wordt losgelaten. Ook behoort in deze categorie de reclame voor antiroosshampoo die aantoont dat bij een eerste 'afspraakje' de schouders niet vol roos mogen liggen. Maar ook de mogelijkheid om aandeelhouder te worden bij een supermarkt en om te kunnen beleggen bij een benzinemaatschappij zijn voorbeelden van hoe de motivatie van de consument om de merkkeuze te evalueren, verhoogd kan worden.

\section{Verbinden van het merk met een onderwerp waarbij de consument betrokken is}

De motivatie van de consument om de merkkeuze te evalueren kan toenemen wanneer het merk in de reclame in verband wordt gebracht een onderwerp waarbij de consument zich betrokken voelt. De verwachting is dat de betrokkenheid bij het onderwerp zal overgaan op de betrokkenheid bij het merk. Voorbeelden hiervan zijn de campagnes waarin een Cola-merk appelleert aan waarden als vrede, gelijkheid, vrijheid en geluk die voor elke consument belangrijk zijn. In reclame voor sigaretten wordt het roken vaak op soortgelijke wijze gekoppeld aan mannelijkheid en onafhankelijkheid.

\section{Benadrukken van het belang van de sterke punten van het merk}

Deze strategie van het versterken van het belang van de sterke punten van het merk bij de consument is moeilijker dan de vorige strategieën, omdat van de consument gevraagd wordt dat hij/zij een wijziging aanbrengt in het gewicht dat wordt toegekend aan de verschillende attributen van een merk. Het sterkste punt van de aanbieder, 'moet' het belangrijkste attribuut worden voor de consument. Hierdoor wordt de consument 'gedwongen' een merk opnieuw te evalueren. Een voorbeeld zijn de koeriersbedrijven: in plaats van zich te profileren op basis van snelheid, profileren zij zich op betrouwbaarheid. Een ander voorbeeld zijn de haarshampoos; alle shampoos wassen het haar schoon, maar slechts een aantal voorkomen het splijten van de haarpunten. Deze strategie helpt in feite ook bij het verminderen van het gepercipieerde risico van consumenten.

\section{Introduceren van een belangrijk nieuw attribuut}

Het introduceren van een belangrijk nieuw attribuut van een merk kan de motivatie van consumenten om het merk te evalueren eveneens doen toenemen. Ook hierdoor wordt de consument min of meer 'gedwongen' een merk opnieuw te evalueren omdat het nieuwe attribuut bij de evaluatie wordt betrokken. Voorbeelden van deze strategie zijn het toevoegen van conditioner aan haarshampoo, de introductie van het automatische 
terugspoelen van het filmpje in een fotocamera en het cassettebandje dat geen ruis produceert.

Uiteraard zorgen de vijf gepresenteerde strategieën er niet voor dat een consument die voorheen in het geheel niet gemotiveerd is om de merkkeuze te evalueren, nu opeens zeer gemotiveerd is. De strategieën kunnen er echter wel toe bijdragen dat de bestaande motivatie om de merkkeuze te evalueren, wordt verhoogd.

\section{Tevredenheid}

Tevredenheid ontstaat wanneer een merk de prestatie levert die een consument ervan verwacht, of indien de verwachtingen overtroffen worden. Om de mate van tevredenheid te vergroten kunnen we de volgende aanbevelingen doen. Deze zijn afhankelijk van het vergelijkingsproces dat plaatsvindt bij de beoordeling van de prestatie (zie paragraaf 2.4.1). Onze aanbevelingen om de tevredenheid van de consument met een merk te vergroten gaan er van uit, dat de assimilatie- en/of de assimilatie-contrasttheorie dit vergelijkingsproces het beste verklaren.

\section{Voldoen aan de verwachtingen of deze overtreffen}

In principe dient iedere aanbieder van ieder merk die streeft naar tevreden consumenten er voor te zorgen dat aan de verwachtingen van de consument over de feitelijke produktprestatie wordt voldaan of dat deze verwachtingen eventueel worden overtroffen. Forse overdrijving in de communicatie over een merk waardoor het verschil tussen verwachtingen en prestatie voor de consument niet langer acceptabel is, leidt tot een negatief effect: de consument is niet tevreden met het merk. Maar:

\section{Lichte overdrijving mag}

De communicatie rondom het merk kan er echter ook op gericht zijn, dat de verwachtingen van de consument net iets hoger komen te liggen dan de feitelijke produktprestatie. Dit kan worden bereikt door gebruik te maken van een lichte overdrijving in de communicatie over de voordelen van het merk. Aangezien het verschil tussen verwachting en prestatie zal worden geassimileerd, zolang het acceptabel is, is de consument meer tevreden dan wanneer de gewekte verwachtingen niet licht overdreven zijn. Dit laatste omdat de perceptie van de prestatie wordt aangepast aan licht overdreven verwachtingen. En lichte overdrijving is, zelfs volgens de Reclame Code Commissie, toegestaan.

\section{'Alle' produktattributen zijn belangrijk}

De aanbieder van een merk dient er van uit te gaan dat alle produktattributen belangrijk zijn voor consumenten. Alle produktattributen moeten daarom tenminste aan de verwachtingen voldoen en acceptabel zijn. Vaak is immers niet exact duidelijk is wat de belangrijkste attributen van een merk voor een individuele consument zijn. 
Een aanbieder kan alleen dan optimaal inspelen op de wensen en de behoeften van de consument (en zo zorgen voor optimale tevredenheid), indien de aanbieder voortdurend de veranderingen daarin in kaart brengt. Bij het constateren van verschuivingen in de mate van tevredenheid, kunnen daardoor de noodzakelijke correcties op het beleid of de communicatie-uitingen worden doorgevoerd.

\section{Evaluatie}

Een aanbieder van een merk beschikt over een aantal instrumenten om te bevorderen dat consumenten zijn merk uitgebreid zullen evalueren (en niet alleen maar accepteren):

\section{Verstrekken van duidelijke en begrijpelijke informatie over de produkt attributen}

Om de consument in staat te stellen een merk uitgebreid te evalueren, dient duidelijke en begrijpelijke informatie over het merk aan deze consument te worden verstrekt. Dit betekent bijvoorbeeld dat de relevante produktattributen duidelijk op de verpakking staan, zoals bijvoorbeeld de voedingswaardenwijzer op levensmiddelen. Consumententijdschriften zijn eveneens een goed medium om de verschillende produktattributen te communiceren; daarnaast bieden ze de mogelijkheid aan de consument om op relatief eenvoudige wijze een merk uitgebreid te evalueren.

\section{Aansluiting zoeken bij de waarden van de consument}

De communicatie over een merk dient direct en duidelijk aan te sluiten bij de waarden (eindwaarden of instrumentele waarden) van de consument. Sommige auto's laten hun berijder nooit in de steek en zijn daarom betrouwbaar; een creditcard biedt de vrijheid om op ieder moment en op elke plaats geld te besteden.

\section{Aansluiting zoeken bij de manier waarop de consument een merk evalueert}

De communicatie over een merk dient tevens zoveel mogelijk aan te sluiten bij de manier waarop een merk door de consument wordt geëvalueerd. Evalueert de consument de verschillende attributen afzonderlijk en wordt het oordeel over deze afzonderlijke attributen vervolgens gecombineerd of evalueert de consument het merk in zijn totaliteit. Wanneer de consument een merk op verschillende attributen afzonderlijk evalueert, is het belangrijk dat de communicatie over het merk informatief is en dat die produktattributen worden benadrukt die de consument eenvoudig kan evalueren. Bijvoorbeeld een gedetailleerde produktbeschrijving op de verpakking van een cassettebandje, waardoor het voor de consument gemakkelijk wordt gemaakt de verschillende attributen van het bandje te evalueren. Wanneer de consument het merk niet op de afzonderlijke attributen maar in z'n geheel evalueert, ligt het voor de hand gebruik te maken van image-achtige transformationele communicatie. Een voorbeeld is de communicatie over parfum, likeuren, koffie en haarshampoo. 
Een nadrukkelijke positieve bevestiging van de keuze van de consument door de aanbieder, kan bewerkstelligen dat de consument een merk uitgebreid evalueert. Dit kan door middel van het sturen van een brief waarin de juistheid van de aankoop nog eens wordt onderstreept. Een ander middel is het opbouwen van een relatie met de consument door middel van een 'sponsored magazine'. Een ander voorbeeld betreft de auto-importeurs die, een maand na aankoop van een nieuwe auto, de keuze bevestigen en een consument met een enquête 'dwingen' de auto en de service van door de autodealer uitgebreid te evalueren.

\section{Duidelijk maken dat er verschillen bestaan tussen merken}

De belangrijkste produktattributen moeten worden benadrukt evenals de verschillen die deze attributen van verschillende merken vertonen om de bewuste evaluatie van het merk door de consument te stimuleren. Er kan bijvoorbeeld duidelijk worden gemaakt, dat - ook al wassen alle wasmiddelen goed schoon - niet alle wasmiddelen een ingebouwde wasverzachter hebben. Deze vorm van informatie stimuleert de consument de merkkeuze uitgebreid te evalueren omdat de consument meer en duidelijker verschillen tussen merken percipieert.

Samenvattend betekent dit dat een aanbieder, die de ware merktrouw van zijn consumenten wil vergroten, de volgende punten in acht moet nemen:

- zorg dat de consument optimaal tevreden is met het merk;

- breng het merk in verband met - een belangrijk onderwerp en/of een belangrijke persoonlijke situatie en/of - belangrijke waarden;

- zorg voor onderscheid met concurrerende merken;

- zorg voor duidelijke en begrijpelijke communicatie over het merk; en

- zorg voor het opbouwen van een relatie met de consument.

\subsection{Beperkingen van het onderzoek}

Ieder (wetenschappelijk) onderzoek kent beperkingen. Het erkennen daarvan is voor een deel de kracht van een onderzoek. De beperkingen vormen daarnaast een belangrijke voedingsbodem voor nader onderzoek.

Oók aan dit onderzoek naar de rol van tevredenheid bij de verklaring van ware merktrouw zijn een aantal beperkingen verbonden. Deze zullen achtereenvolgens worden besproken. Op grond daarvan komen wij tot een aantal suggesties en aanbevelingen voor nader onderzoek.

Wellicht de belangrijkste beperking van het onderzoek is het gevolg van de keuze voor een economisch-psychologische benadering van het vraagstuk. Hierdoor is deels voorbij gegaan aan een meer economische invalshoek. De nadruk in het onderzoek heeft gele- 
gen op de (economisch-)psychologische variabelen die van invloed zijn op de verklaring van ware merktrouw.

Daarnaast hebben wij merktrouw en tevredenheid als uitgangspunt genomen en zijn niet nadrukkelijk ingegaan op ontevredenheid en merkontrouw. Er is dus slechts een deel van de werkelijkheid bestudeerd. De werkelijkheid van tevreden consumenten die niet voortdurend veranderen van merk.

In het onderzoeksmodel is niet expliciet rekening gehouden met situationele verschillen. De situatie waarvoor een bepaald merk is aangeschaft c.q. wordt gebruikt, kan van invloed zijn op de relatie tussen ware merktrouw en tevredenheid. Ook is er geen rekening gehouden met een mogelijke domeinspecifieke relatie tussen ware merktrouw en tevredenheid. Hoewel in het onderzoek een vraag was opgenomen naar het kopen van cassettebandjes en shampoo voor een speciale gelegenheid of voor een speciaal gebruik, zijn toch geen verschillende segmenten in de steekproef onderscheiden. Dit heeft te maken met de achteraf, voor ons, onbevredigende antwoorden op deze open-vraag, waardoor een verantwoorde segmentatie onmogelijk werd (met name te algemene antwoorden en te geringe spreiding in de antwoorden).

Daarnaast wordt in het model geen rekening gehouden met het fenomeen van multimerkentrouw: consumenten zijn immers vaak trouw aan meerdere merken tegelijkertijd. Multimerkentrouw is in het onderzoek buiten beschouwing gelaten omdat dit de opzet van het empirisch te zeer complex zou hebben gemaakt.

Andere beperkingen van het empirisch onderzoek betreffen de onderzoekspopulatie, de gekozen produkten en de operationalisatie van de concepten.

Als onderzoekspopulatie is gekozen voor een doorsnede van de Nederlandse bevolking in het jaar 1992. Culturele- en maatschappelijke achtergrond en economische welstand spelen mogelijk een rol bij de gevonden onderzoeksresultaten. In tijden van economische welstand is zoals bekend de merktrouw vaak groter dan in tijden van recessie. De gevonden resultaten kunnen dus tijd gebonden zijn.

In het onderzoek zijn slechts twee produkten betrokken: (onbespeelde) cassettebandjes en haarshampoo. Wij moeten hierbij het voorbehoud maken dat voor andere en met name meer of juist minder duurzame produkten, een andere relatie tussen ware merktrouw en tevredenheid kan bestaan of dat de gevonden verbanden sterker of juist zwakker kunnen zijn omdat bijvoorbeeld de rol van de motivatie per produkt zou kunnen verschillen.

De beperkingen van de operationalisatie van de concepten worden hieronder per concept toegelicht:

\section{Tevredenheid}

De respondenten in het onderzoek zijn bijna allemaal tevreden en de meesten daarvan zijn voor $75 \%$ of meer tevreden. (Dit is overeenkomstig andere tevredenheidsonderzoe- 
ken.) Een eenduidige verklaring voor dit verschijnsel is moeilijk te geven. Het kan zijn dat tevredenheid scheef verdeeld is binnen de populatie, maar het plafond-effect, een response bias, de sociale wenselijkheid, de accuraatheid, de formulering en de context van de vraag kunnen ook een rol hebben gespeeld. Dit betekent dat rekening moet worden gehouden met een zekere mate van onnauwkeurigheid van de operationalisatie van het tevredenheidsconcept. De geconstateerde correlatie-coëfficiënten kunnen hierdoor mogelijk enigszins onderschat zijn.

\section{Ware merktrouw}

De manier waarop wij ware merktrouw uiteindelijk in hoofdstuk 8 hebben geoperationaliseerd (loyaliteit) is - voor zover ons bekend - 'nieuw': de kans op een herhalingsaankoop waarbij rekening wordt gehouden met de mate van commitment. Over de betrouwbaarheid van deze maat kan, in het kader van het onderzoek, slechts indirect een uitspraak worden gedaan. In het onderzoek is namelijk vastgesteld dat commitment voldoende betrouwbaar is gemeten. Daamaast veronderstellen wij dat de kans op een herhalingsaankoop, een maat die veelvuldig in onderzoek wordt gebruikt, tevens betrouwbaar is. De validiteit kan afgaande op het oordeel van enkele 'experts' en de in het onderzoek vastgestelde relatie tussen loyaliteit en tevredenheid, vooralsnog als voldoende worden beschouwd. Desalniettemin is de betrouwbaarheid en de validiteit van de maat nog niet afdoende onderzocht. Onze aanvankelijke maat van ware merktrouw beschouwen wij achteraf als minder valide.

\section{Commitment, merkkeuze-involvement en elaboratie}

De schalen voor het meten van commitment, merkkeuze-involvement en elaboratie zijn betrouwbaar en valide bevonden binnen het kader van het onderzoek en voor de in het onderzoek gebruikte produkten.

\section{$9.4 \quad$ Suggesties voor nader onderzoek}

De suggesties voor nader onderzoek sluiten nauw aan bij de beperkingen van het onderzoek. De belangrijkste suggesties leiden tot een opheffing of een vermindering van de vastgestelde beperkingen. Daamaast kunnen een aantal suggesties voor nader onderzoek worden geformuleerd waardoor het onderzoek naar de relatie tussen ware merktrouw en tevredenheid in een breder kader wordt geplaatst doordat een aantal van de randvoorwaarden wordt losgelaten.

Uit het literatuuroverzicht in hoofdstuk 1 en 2 is gebleken dat in het onderzoek naar merktrouw de invloed van veel factoren reeds onderzocht is, maar dat de rol van tevredenheid daar niet expliciet in aan de orde is geweest. In ons onderzoek is expliciet aandacht besteed aan de invloed van tevredenheid en geen aandacht aan de andere factoren. $\mathrm{Nu}$ is gebleken dat tevredenheid een rol speelt bij de verklaring van ware merktrouw en op welke wijze, moet geconcludeerd worden dat in toekomstig onderzoek zowel de reeds bekende factoren als tevredenheid (manifest of latent) simultaan aan de orde moeten komen. 
Naast de door ons in het onderzoeksmodel opgenomen variabelen zouden met name meer economische variabelen of marketing-variabelen moeten worden opgenomen. Reclame is zo'n marketing-variabele. Reclame speelt ons inziens niet alleen een directe rol bij ware merktrouw, maar speelt tevens een directe rol bij tevredenheid. Deze effecten van reclame op ware merktrouw, moeten aan nader onderzoek worden onderworpen. Ook zou de rol van de verschillende produktattributen, prijs, personeel en distributie op de relatie tussen ware merktrouw en tevredenheid nader dienen te worden onderzocht.

Daamaast dient er nader aandacht te worden besteed aan de produkt-, de domein- en de situatie-specificiteit van ware merktrouw. Op dit moment is er onvoldoende inzicht om vast te kunnen stellen of en zo ja, in welke mate ware merktrouw afhankelijk is van het produkt (of eventueel het merk), het domein waarop of de situatie waarin het produkt wordt gebruikt. De door ons gehanteerde vraagstelling dient te worden verbeterd omdat deze niet goed bruikbaar bleek.

Uiteraard zal er onderzoek moeten worden gedaan met andere produkten: meer duurzame of juist minder duurzame produkten dan cassettebandjes en haarshampoo. Belangrijker is nog, indien mogelijk, produkten (zowel goederen als diensten) te selecteren die duidelijk verschillen ten aanzien van hoe uitgebreid zij worden geëvalueerd door consumenten, of consumenten te selecteren die verschillende produkten in verschillende mate evalueren.

Een andere suggestie betreft het feit dat in het onderzoek alleen intenties zijn gemeten en dat in de toekomst nadere aandacht zal moeten worden besteed aan het feitelijk gedrag van de consument. Door het gebruik van onder andere scanning data, zal het steeds eenvoudiger worden om het feitelijk gedrag in het onderzoek naar ware merktrouw te betrekken.

Bovendien dient het onverwachte negatieve effect van deliberatie op ware merktrouw nader te worden onderzocht.

Uit ons empirisch onderzoek waarbij verschillende, theoretisch verantwoorde operationalisaties van ware merktrouw zijn gehanteerd, is gebleken dat de operationalisatie van ware merktrouw geen betrekking moet hebben op de manier waarop een merk opnieuw gekocht wordt. In de operationalisatie dienen zowel de gedragscomponent van ware merktrouw (het feitelijk koopgedrag) als de mate van commitment bij het merk naar voren te komen. 


\section{Literatuur}

Aaker, D.A., "A measure of brand acceptance", Journal of Marketing Research, 9 (1972), p. 160-167.

Aaker, D.A., Managing brand equity, New York, The Free Press, 1991.

Adams, J.S., "Towards an understanding of inequity", Journal of Abnormal and Social Psychology, 67 (1963), p. 422-436.

Advertising Research Foundation, "Are there consumer types?", New York, Advertising Research Foundation, 1964.

Anderson, E.E., "The measurement of buyer brand preference and indifference under changing terms of trade", American Journal of Agricultural Economics, 56 (1974), p. 122-128.

Anderson, L.K., J.R. Taylor en R.J. Holloway, "The consumer and his alternatives; an experimental approach", Journal of Marketing Research, 3 (1966), p. 62-67.

Anderson, N.H., Information integration theory: a case history in experimental science, vol. 1, New York, Academic Press, Inc., 1981.

Anderson, R.E., "Consumer dissatisfaction: The effect of disconfirmed expectancy on perceived product performance", Journal of Marketing Research, 10 (1973), p. 38-44.

Andreasen, A.R., "A taxonomy of consumer satisfaction/dissatisfaction measures", in: H.K. Hunt (ed.), Conceptualization and measurement of consumer satisfaction and dissatisfaction, Cambridge, MA, Marketing Science Institute, 1977, p. 11-35.

Andreasen, A.R., "Consumer responses to dissatisfaction in loose monopolies", Journal of Consumer Research, 12 (1985), p. 135-140.

Andrews, C.J., S. Durvasula en S. Akhter, "A framework for conceptualization and measuring the involvement construct in advertising research", Journal of Advertising, 19 (1990), p. 27-40.

Antil, J.H., "Conceptualization and operationalization of involvement", Advances in Consumer Research, 11 (1984), p. 203-209.

Aronson, E. en J.M. Carlsmith, "Experimentation in social psychology", in: G. Lindzey and E. Aronson (eds.), Handbook of Social Psychology, vol. 2 Reading, Massachusetts; Addison-Wesley, 1968.

Assael, H., Consumer Behavior and Marketing Action, Boston, Kent Publishing Company, 1987, third edition.

Assael, H., Consumer Behavior and Marketing Action, Boston, Kent Publishing Company, 1992, fourth edition.

Batra, R. en M.L. Ray, "Operationalization of involvement as depth and quality of cognitive response", Advances in Consumer Research, 10 (1983), p. 309-313.

Bearden, W.O. en J.E. Teel, "Selected determinants of consumer satisfaction and complaint reports", Journal of Marketing Research, 20 (1983), p. 21-28.

Beatry, S.E., P. Homer en L.R. Kahle, "The involvement - commitment model: theory and implications", Journal of Business Research, 16 (1988), p. 149-167.

Beatty, S.E. en L.R. Kahle, "Alternative hierarchies of the attitude-behavior relationship; the impact of brand commitment and habit", Journal of the Academy of Marketing Science, 16 (1988), p. 1-10.

Beatty, S.E. en S.M. Smith, "External search effort; an investigation across several product categories", Journal of Consumer Research, 14 (1987), p. 83-95.

Belk, R.W.. "Effects of gift-giving involvement on gift selection strategies", Advances in Consumer Research, 9 (1982), p. 408-411.

Bellenger, D.N., E. Steinberg en W.W. Stanton, "The congruence of store image and self image; as it relates to store loyalty". Journal of Retailing, 52 (1976), p. 17-32.

Belonax, J.J. en R.G. Javalgi, "The influence of involvement and product class quality on consumer choise sets", Journal of the Academy of Marketing Science, 17 (1989), p. 209-216.

Bennett, P.D. en H.H. Kassarjian, Consumer Behavior, Englewood Cliffs, New Jersey, Prentice-Hall, 1972. 
Bettman, J.B., An information processing theory of consumer choice, Phillippines, Addison-Wesley Publishing Company, 1979.

Beukenkamp, P.A. en P. Th. Gründemann, Behandeling van klachten van levensmiddelenconsumenten, Rotterdam, Erasmus Universiteit, Centrum voor Bedrijfstechnisch Onderzoek, rapport nr. 7920M, 1979.

Bloch, P.H., "An exploration into the scaling of consumers' involvement with a product class", Advances in Consumer Research, 8 (1981), p. 61-65.

Bloch, P.H., "Involvement beyond the purchase process issues and empirical investigation", Advances in Consumer Research, 9 (1983), p. 413-417.

Bloch, P.H. en M.L. Richins, "A theoretical model of the study of product importance perceptions", Journal of Marketing, 47 (1983), p. 69-81.

Bloemer, J.M.M., J.D.P. Kasper en J.G.A.M. Lemmink, "The relationship between overall dealer satisfaction, satisfaction with the attributes of dealer service, intended dealer loyalty and intended brand loyalty: a Dutch automobile case", Journal of Consumer Satisfaction, Dissatisfaction and Complaining Behavior, 3 (1990), p. 42-47.

Bloemer, J.M.M. en J.G.A.M. Lemmink, "The importance of customer satisfaction in explaining brand and dealer loyalty", Proceedings of the 20ih European Marketing Academy Conference, Dublin, vol. 4, 1991, p. 1340-1355.

Bloemer, J.M.M. en J.G.A.M. Lemmink, "The importance of customer satisfaction in explaining brand and dealer loyalty", Journal of Marketing Management, 8 (1992), p. 351-364.

Bloemer, J.M.M. en Th.B.C. Poiesz, "The illusion of consumer satisfaction", Journal of Consumer Satisfaction, Dissatisfaction and Complaining Behavior, 2 (1989), p. 43-48.

Brown, G.H., "Brand loyalty - fact or fiction?", Advertising Age, 23 (1952), p. 53-55/45-47/54-56/46-48/56-5-8/76-79.

Bubb, P.L. en D.J. van Rest, "Loyalty as a component of industrial buying decision", Industrial Marketing Management, 3 (1973), p. 25-32.

Burford, R.L., B.M. Enis en G.W. Paul, "An index for the measurement of consumer loyalty", Decision Sciences, 2 (1971), p. 17-24.

Burmann, Ch., "Konsumentenzufriedenheit als Determinante der Marken- und Händlerloyalität", Zeitschrift für Forschung und Praxis, 13 (1991), p. 249-258.

Cacioppo, J.T. en R.E. Petty, "The need for cognition", Journal of Personality and Social Psychology, 42 (1982), p. 116-131.

Cadotte, E.R., R.B. Woodruff en R.L. Jenkins, "Expectations and norms in models of consumer satisfaction", Journal of Marketing Research, 24 (1987), p. 305-314.

Cardozo, R.N., "An experimental study of customer effort, expectation and satisfaction", Journal of Marketing Research, 2 (1965), p. 244-249.

Carlsmith, J.M. en E. Aronson, "Some hedonic consequences of the confirmation and disconfirmation of expectancies", Journal of Abnormal and Social Psychology, 66 (1963), p. 151-156.

Carman, J.M., "Brand switching and linear learning models", Journal of Advertising Research, 6 (1966), p. 23-31.

Carman, J.M., "Correlates of brand loyalty; some positive results", Journal of Marketing Research, 7 (1970), p. 67-76.

Carpenter, G.S. en D.R. Lehman, "A model of marketingmix, brand switching and competition", Journal of Marketing Research, 22 (1985), p. 318-329.

Celsi, R.L. en J. Olson, "The effects of felt involvement on consumers' attitude and comprehension process", Working paper: Marketing Science Institute, Cambridge, 1989, Report No. 89-111.

Chaiken, S., "Heuristic versus systematic information processing and the use of source versus message cues in persuasion", Journal of Personality and Social Psychology, 39 (1980), p. 752-756.

Charlton, P. en D.S.C. Ehrenberg, "An experiment in brand choice", Journal of Marketing Research, 13 (1976), p. 152-160.

Churchill, G.A., "A paradigm for developing better measures of marketing constructs", Journal of Marketing Research, 16 (1979), p. 64-73.

Churchill, G.A. en C. Suprenant, "An investigation into the determinants of consumer satisfaction", Journal of Marketing Research, 19 (1982), p. 491-504.

Churchill, H., "How to measure brand loyalty", Advertising and Selling, 35 (1942), p. 24.

Clarke, $\mathrm{K}$. en R. Belk, "The effects of product involvement and task definition on anticipated consumer effort", Advances in Consumer Research, 5 (1978), p. 315-318. 
Cohen, J.B., "Involvement and You: 1000 great ideas", Advances in Consumer Research, 10 (1983), p. 325. 328.

Cohen, J.B. en P. Cohen, Applied multiple regression / Correlation analysis for the behavioral sciences, Hillsdale, NJ, Lawrence Erlbaum, 1983.

Cohen, J.B. en M.E. Goldberg, "The dissonance model in post-decision product evaluation", Journal of Marketing Research, 7 (1970), p. 315-321.

Cohen, J.B. en M.J. Houston, "Cognitive consequences of brand loyalty", Journal of Marketing Research, 9 (1982), p. 97-99.

Comrey, A.L., A first course in factor analysis, New York, Academic Press, 1973.

Copeland, M.T., "Relation of consumer's buying habits to marketing methods", Harvard Business Review, 1 (1923), p. 282-289.

Costley, C.L., "Meta-analysis of involvement research", Advances in Consumer Research, 15 (1988), p. 554-562.

Coulson, J.S., "Buying decisions within the family", in: J. Newman (ed.), On knowing the consumer, New York, John Wiley and Sons, 1966, p. 66.

Cronbach, L., "Statistical tests for moderator variables: flaws in analyses recently proposed", Psychological Bulletin, 102 (1986), p. 414-417.

Crosby, L.A. en J.R. Taylor, "Psychological commitment and its effects on post decision evaluations and preference stability among voters", Journal of Consumer Research, 9 (1983), p. 413-431.

Cullen, C.W. en S.J. Edget, "The cognitive and affective dimensions of involvement in service organization selection", Proceedings of the 20th European Marketing Academy Conference, Dublin, 3 (1991), p. 634 650.

Cunningham, R.M., "Brand loyalty - what, where, how much?", Harvard Business Review, 34 (1956), p. 116-128.

Cunningham, R.M., "Customer loyalty to store and brand", Havard Business Review, 39 (1961), p. 127-128.

Cunningham, S.M., "Perceived risk and brand loyalty", in: D.F. Cox (ed.), Risk taking and information handling in consumer behavior, Boston: Harvard University Press, 1967, p. 507-523.

Dawes, R.M., D. Singer en F. Lemans, "An experimental analysis of constrast effects and its implications for intergroup communication and the indirect assessment of attitude". Journal of Personality and Social Psychology, 21 (1972), p. 281-295.

Day, G.S., "A two-dimensional concept of brand loyalty", Journal of Advertising Research, 9 (1969), p. 29-35.

Day, R.L., "Toward a process model of consumer satisfaction", in: H.K. Hunt (ed.), Conceptualization and measurement of consumer satisfaction and dissatisfaction, Cambridge. MA, Marketing Science Institute, 1977, p. 153-183.

Day, R.L., "The next step: Commonly accepted constructs for satisfaction research", in: R.L. Day en H.K. Hunt (eds.), International fare in consumer satisfaction and complaining behavior, Bloomington, $\mathbb{N}$, Indiana University Press, 1983, p. 113-117.

Day, R.L. en M. Bodur, "A comprehensive study of satisfaction with consumer services", in: R.L. Day (ed.), Consumer satisfaction. dissatisfaction and complaining behavior, Bloomington, IN, Indiana University Press, 1977, p. 64-74.

Day, R.L. en E.L. Landon, "Towand a theory of consumer complaining behavior", in: Woodwick, A.G., J.N. Sheth en P.D. Bennet (eds.), Consumer and industrial buying behavior, North Holland, 1977, p. 425-437.

Deighton, J., "The interaction of advertising and evidence", Jowrnal of Consumer Research, 11 (1984), p. 763-770.

Dommermuth, W.P., "Shopping matrix and marketing strategy", Journal of Marketing Research, 2 (1965), p. $128-132$.

Dröge, C. en D. Halstead, "Postpurchase hierarchies of effects: the antecedents and consequences of satisfaction for complainers versus non-complainers", International Journal of Research in Marketing. 8 (1991), p. 315-328.

Dube, L. en B. Schmitt, "The processing of emotional and cognitive aspects of product use in satisfaction judgements", Advances in Consumer Research, 18 (1991), p. 52-55.

Duhaime, C. en S.B. Ash, "Satisfaction, dissatisfaction and complaining behavior: A comparison of male and female consumer", in: H.K. Hunt en R.L. Day (eds.), Refining concepts and measures of consumer satisfaction and complaining behavior, Bloomington, IN, Indiana University Press, 1980, p. 102-111. 
Dupuy, G.M., "The institutional loyalty of new residents; the bank selection decision", Dissertation abstracts 35, 4784a, 1975.

Dwyer, F.R., P.H. Shurr en S. Oh, "Developing buyer-seller relationships", Journal of Marketing, 51 (1987), p. 11-21.

Earl, P.E., "Economics and psychology: a survey", The Economic Journal, 100 (1990), p. 718-755.

Ehrenberg, A.S.C. (ed.), "Repeat Buying; theorie and application", American Elsevier, New York, 1972.

Ehrenberg, A.S.C. en P. Charlton, "An analysis of simulated brand choice", Journal of Advertising Research, 13 (1973), p. 21-33.

Engel, J.F. en R.D. Blackwell, "Brand loyalty and repeat purchase behavior", in: Consumer Behavior, The Dryden Press, Chicago, 1982, fourth edition.

Engel, J.F., R.D. Blackwell en P.W. Miniard, Consumer Behavior, Chicago, The Dryden Press, 1986, fifth edition.

Engel, J.F., R.D. Blackwell en P.W. Miniard, Consumer Behavior, Chicago, The Dryden Press, 1990, sixth edition.

Engel, J.F. en M.L. Light, "The role of psychological commitment in consumer behavior: an evaluation of the theory of cognitive dissonance", in: F.M. Boss (ed.), Application of the sciences in Marketing Management, New York, Wiley, 1986, p. 39-68.

Farley, J.U., "Why does brand loyalty vary over products?", Journal of Marketing Research, 1 (1964), p. 9-14.

Festinger, L., A theory of cognitive dissonance, New York, Harper and Row, 1957.

Fisk, R.P. en C.E. Young, "Disconfirmation of equity expectations: effects on consumer satisfaction with services", in: E. Hirschman en H. Holbrook (ed.), Advances in Consumer Research, 1985, p. 340-345.

Folkes, V.S., "Consumer reactions to product failure: an attributional approach", Journal of Consumer Research, 10 (1984), p. 398-409.

Ford, D. (ed.), Understanding Business Markets: Interaction, Relationship and Networks, London, Academic Press, 1990.

Fornell, C., "A national customer satisfaction barometer: the Swedish experience", Journal of Marketing, 56 (1992), p. 6-21.

Fornell, C. en W.T. Robinson, "Industrial organization and consumer satisfaction/dissatisfaction", Journal of Consumer Research, 9 (1983), p. 403-412.

Francken, D.A. en W.F. van Raaij, "Socio-economic and demographic determinants of consumer problem perception", Journal of Consumer Policy, 8 (1985), p. 303-313.

Frank, R.E., "Brand choice as probability process", Journal of Business, 35 (1962), p. 43-56.

Frank, R.E., "Is loyalty a usefull basis for marketsegmentation", Journal of Advertising Research, 7 (1967), p. 27-33.

Frank, R.E. en H. Boyd Jr., "Are private-brand-prone grocery customers really different?", Journal of Advertising Research. 5 (1965), p. 27-35.

Frank, R.E., W.F. Massy en T.M. Lodahl, "Purchasing behavior and personal attributes", Journal of Advertising Research, 9 (1969), p. 15-24.

Frank, R.E., W.F. Massy en D.G. Morrison, "The determinants of household innovative behavior for a branded, frequently purchased food product", Proceedings of the American Marketing Association, 1964.

Francken, D.A., "Postpurchase consumer evaluations, complaint actions and repurchase behavior", Journal of Economic Psychology, 4 (1983), p. 273-290.

Franzen, G. en F. Holzhauer, Het merk deel I $t / m$ VIII, Deventer, Kluwer Bedrijfswetenschappen, 1987.

Freedman, J.L., "Involvement, discrepancy and change", Journal of Abnormal and Social Psychology, 69 (1964), p. 290-295.

Fry, J.N., D.C. Shaw, C. Haehling von Lansenauer and C.R. Dipchand, "Customer loyalty to banks; a longitudinal study", The Journal of Business, 46 (1973), p. 517-525.

Garfein, R., "Evaluating the impact of customer service delivery systems", Marketing Review, 42 (1987). p. 11-15.

Goldsmith, R.E., J. Emmert en C. Hofacker, "A causal model of consumer involvement: replication and extension", Proceedings Winter Educators' Conference, 1991, p. 330-338.

Green, P.E., D.S. Tull en G. Albaum, Research for Marketing Decisions, New Jersey, Englewood Cliffs, 1988, fifth edition.

Greenwald, A.G. en C. Leavitt, "Audience involvement in advertising: four levels", Journal of Consumer Research, 11 (1984), p. 581-592. 
Grönhaug, K., "Exploring consumer complaining behavior: A model and some empirical results", in: W.D. Perreault (ed.), Advances in Consumer Research, 4 (1977), p. 159-165.

Grönhaug, K. en M.C. Gilly, "A transaction cost approach to consumer dissatisfaction and complaint behavior", Journal of Economic Psychology, 12 (1991), p. 165-183.

Guest, L.P., "Last vs. usual purchase questions", Journal of Applied Psychology, 26 (1942), p. 180-186.

Guest, L.P., "Brand loyalty - twelve years later", Journal of Applied Psychology, 39 (1955), p. 405-408.

Guest, L.P., "Brand loyalty revisited: a twenty year report", Journal of Applied Psychology, 48 (1964), p. 93-97.

Hakansson, H., International Marketing and Purchasing of Industrial Goods; an Interaction Approach, Chichester, John Wiley, 1982.

Halstead, D. en Th.J. Page Jr., "The effects of satisfaction and complaining behavior on consumer repurchase intentions", Journal of Consumer Satisfaction/Dissatisfaction and Complaining Behavior, 5 (1992), p. 1-11.

Handy, C.R., "Applications of the index of consumer satisfaction for public policy pertaining to market performance", in: M. Venkatesan (ed.), Proceedings of the Third Annual Conference of the Association of Consumer Research, 1972, p. 738-741.

Hansen, F., "Hemispheral lateralization: implications for understanding consumer behavior", Journal of Consumer Research, 8 (1981), p. 23-36.

Hansen, F., "Involvement of interest or what?", Advances in Consumer Research, 12 (1985).

Harary, F. en B. Lipstein, "The dynamics of brand loyalty; a Markov approach", Operations Research, 10 (1962), p. 19-40.

Hauser, J.R. en P. Simmi, "Profit maximizing perceptual positions; an integrated theory for the selection of product features and price", Management Science, 27 (1981), p. 33-56.

Hausknecht, D.R., "Measurement scales in consumer satisfaction/dissatisfaction", Journal of Consumer Satisfaction/Dissatisfaction and Complaining Behavior, 3 (1990), p. 1-11.

Heider, F., The psychology of interpersonal relations, New York, John Wiley, 1958.

Helsen, K. en D.C. Schmittlein, "Understanding the nature of price responsiveness for new brand introductions", Proceedings of the 21th European Marketing Academy Conference, Aarhus, 1992, p. $563-580$.

Helson, H., Adaptation-level theory, New York, Harper and Row, 1964.

Herzberg, F., B. Mausner en B.B. Synderman, The motivation to work, New York, John Wiley \& Sons, 1959, second edition.

Hirschman, A.O., Exit, voice, loyalty: responses to decline in firms, organizations and states, Cambridge, Harvard University Press, 1970.

Hoch, S.J. en Y.W. Ha, "Consumer learning: advertising and the ambiguity of product experience", Journal of Consumer Research, 13 (1986), p. 221-233.

Holbrook, M.B., "Situation-specific ideal points and usage of multiple dissimilar brands", in: J.N. Sheth (ed.), Research in Marketing, 7 (1984), p. 93-131.

Holbrook, M.B. en E.C. Hirschman, "The experiental aspects of consumption: consumer fantasies, feelings and fun", Journal of Consumer Research, 9 (1982), p. 132-140.

Hollenbeck, J.R., A.M. O'Leary, H.J. Klein and P.M. Wright, "Investigation of the construct validity of a self-report measure of goal commitment", Journal of Applied Psychology, 74 (1989), p. 951-956.

Houston, M.J. en M.L. Rothschild, "Conceptual and methodological perspectives in involvement", in: S.C. Jain (ed.), Educators' Proceedings, Chicago: American Marketing Association, 1978, p. 184-187.

Hovland, C.I., OJ. Harvey en M. Sherif, "Assimilation and contrast effects in reactions to communication and attitude change", Journal of Abnormal and Social Psychology, 55 (1957), p. 244 -250.

Howard, J.A. en J.N. Sheth, The theory of buyer behavior, New York, John Wiley, 1969.

Hunt, H.K., "CS/D - Overview and future research directions", in: H.K. Hunt (ed.), Conceptualization and measurement of consumer satisfaction and dissatisfaction, Cambridge, MA, Marketing Science Institute. 1977 , p. $455-488$.

Hunt, J.M., "Consumer responses to inequitable economic exchanges: an attribution theoretical analysis", in: H.K. Hunt en R.L. Day (eds.), Refining concepts and measures of consumer satisfaction and complaining behavior, Bloomington, IN, Indiana University Press, 1980, p. 23-28.

Hunt, S.D., V.R. Wood en L.B. Chonko, "Corporate ethical values and organizational commitment in marketing", Journal of Marketing, 53 (1989), p. 79-90. 
Hupfer, N.T. en D.M. Gardner, "Differential involvement with products and issues: An exploratory study", in: D.M. Gardner (ed.), Proceedings of the Assaciation for Consumer Research, 2nd Conference, College Park, M.D., 1971, p. 262-270.

I.P.M. / Interview Consumentisme, Schiedam, IPM, Interview, Amsterdam, 1974/1981.

Ilgen, D.R., "Satisfaction with performance as a function of the initial level of expected performance and the deviation from expectation", Organizational behavior and human performance, 6 (1971), p. 345-361. Jacoby, J., "Toward a multi-brand model of brand loyalty", Purdue Papers in Consumer Psychology, Paper no. $105,1969$.

Jacoby, J., "Brand loyalty; a conceptual definition", Proceedings American Psychological Association, 6, (1971a), p. 655-656.

Jacoby, J., "A model of multi-brand loyalty", Journal of Advertising Research, 11 (1971b), p. 25-31. Jacoby, J. en R.W. Chesnut, Brand loyalty measurement and management, New York, John Wiley and Sons, 1978.

Jacoby, J., W. Jones en R.W. Chesnut, "Intent to purchase and the regions of brand acceptance", Purdue Papers in Consumer Psychology, 1979.

Jacoby, J. en D. B. Kyner, "Brand Loyalty versus repeat purchase behavior", Journal of Marketing Research, 10 (1973), p. 1-9.

Jacoby, J. en J.C. Olson, "An attitudinal model of brand loyalty; conceptual underpinnings and instrumentation research", Paper presented at the University of Illinoic Conference on Attitude Research and Consumer Behavior, Urbana, Illiois, December 1970.

Jarvis, L.P. en J.B. Wilcox, "Repeat pruchasing behavior and attitudinal brand loyalty; additional evidence", in: K.L. Bernhardt (ed.), Marketing: 1976 and beyond, American Marketing Association, 1976, p. 151-152.

Jensen, Th.D., L. Carlson en C. Tripp, "The dimensionality of involvement", Advances in Consumer Research, 16 (1989), p. 680-689.

Jeuland, A.P., "Brand choice inertia as one aspect of the notion of brand loyalty", Management Science, 25 (1979), p. 671-682.

Johnson, M.D. en C. Fornell, "A framework for comparing customer satisfaction across individuals and product categories", Journal of Economic Psychology, 12 (1991), p. 267-286.

Kahn, B.E., M.U. Kalwani en D.G. Morrison, "Measuring variety-seeking and reinforcement behavior using panel data", Journal of Marketing Research, 23 (1986), p. 89-100.

Kapferer, J.N. en G. Laurent, "Consumer involvement profiles: a new practical approach to consumer involvement", Journal of Advertising Research, 25 (1985-1986), p. 48-56.

Kasper, J.D.P., Marketing en consumentensoevereiniteit, een onderzoek naar de invloed van consumentenklachten op de strategie van de onderneming, Amsterdam, VU Boekhandel/Uitgeverij, 1982.

Kasper, J.D.P., "On problem perception, dissatisfaction and brand loyalty", Journal of Economic Psychology, 9 (1988), p. 387-397.

Katona, G. en E. Mueller, "A study of puchase decisions", in: L.H. Clarck (ed.), Consumer Behavior, The dynamics of consumer reaction, New York, New York University Press, 1954.

Kiesler, C.A., "Commitment", in: R.P. Abelson et al. (eds.), Theories of cognitive consistency: a sourcebook, Chicago, Rand McNally, 1968, p. 448-455.

Kraft, F.B., D.H. Granbois en J.O. Summers, "Brand evaluation and brand choice: a longitudinal study", Journal of Markering Research, 10 (1973), p. 235-241.

Krishnamurthi, L. en S.P. Raj, "An empirical analysis of the relationship between brand loyalty and consumer price elasticity", Marketing Science, 10 (1991), p. 172-183.

Krugman, H.E., "The impact of television advertising: leaming without involvement", Public opinion Quaterly, 29 (1965), p. 349-356.

Krugman, H.E., "The measurement of advertising involvement", Public Opinion Quaterly, 30 (1966), p. 583-596.

Kuehn, A.A., "Consumer brand choice as a leaming process", Journal of Advertising Research, 2 (1962), p. 10-17.

LaBarbera, P.A. en D. Mazursky, "A longitudinal assesment of consumer satisfaction/dissatisfaction", Journal of Marketing Research, 20 (1983), p. 393-404.

Lamont, L.M. en J.T. Rothe, "The impact of unit pricing on channel systems", Proceedings American Marketing Association, 1971, p. 653-658.

Lancaster, K., Consumer Demand, A New Approach, New York, Columbia University Press, 1971. 
Landon, E.L., "A model of consumer complaint behavior", in: R.L. Day (ed.), Consumer Satisfaction, Dissatisfaction and Complaining Behavior, Bloomington, IN, Indiana University Press, 1977, p. 31-35.

Lastovicka, J.L. en E.H. Bonfield, "Do consumers have brand attitudes?", Journal of Economic Psychology, 2 (1982), p. 57-70.

Lastovicka, J.L. en D.M. Gardner, "Components of involvement", in: J.C. Maloney en B. Silverman (eds.), Attitude Research Plays for High Stokes, American Marketing Association, 1977, p, 53-73.

Lastovicka, J.L. en D.M. Gardner, "Low involvement versus high involvement cognitive structures", Advances in Consumer Research, 5 (1978), p. 87-92.

LaTour, S.A. en N.C. Peat, "Conceptual and methodological issues in consumer satisfaction", in: W. Wilkie (ed.), Advances in Consumer Research, 6 (1979), p. 31-37.

Laurent, G. en J.N. Kapferer, "Measuring consumer involvement profiles", Journal of Marketing Research, 22 (1985), p. 41-53.

Leavith, C., "Consumer satisfaction and dissatisfaction: bipolar and independent", in: H.K. Hunt (ed.), Conceptualization and measurement of consumer satisfaction and dissatisfaction, Cambridge, MA, Marketing Science Institute, 1977, p. 132-152.

Lee, B.A. en Z.A. Zeiss, "Behavioral commitment to the role of sport consumer: an exploratory analysis", Sociology and Social Research, 64 (1980), p. 405-415.

Lemmink, J.G.A.M., Kwaliteitsconcurrentie tussen ondernemingen, Datawyse, Maastricht, 1991.

Leichty, M. en G.A. Churchill, "Conceptual insight into consumer satisfaction with services", in: N. Beckwith et al. (eds.), Educators' Conference Proceedings, Series 94, Chicago, American Marketing Association, 1979, p. 509-515.

Lingoes, J.C. en M. Pfaff, "The index of consumer satisfaction: methodology", in: M. Venkatesan (ed.), Advances in Consumer Research, 1972, p. 689-712.

Livesy, F., "Brand loyalty and the television rental market", European Journal of Marketing, 7 (1973/74), p. 218-231.

Locke, E.A., "The nature and causes of job satisfaction", in: M.D. Dunette (ed.), Handbook of Industrial and Organizational Psychology, Chicago, Rand McNally College Publishing Company, 1977, p. 1297 1350.

Lutz, RJ. en P.W. Winn, "Developing a Bayesian measure of brand loyalty; a preliminary report", in: R.C. Corhan (ed.), 1974 Combined Proceedings, Chicago; American Marketing Association, 1975, p. 104-108.

Maddox, R., "Two factor theory and consumer satisfaction: replication and extention", Journal of Consumer Research, 8 (1981), p. 97-102.

Maheswaran, D. en J. Meyers-Levy, "The influence of message framing and involvement", Journal of Marketing Research, 27 (1990), p. 361-367.

Massy, W.F. en R.E. Frank, "Short term price and dealing effects in selected market segments", Journal of Marketing Research, 2 (1965), p. 171-185.

Massy, W.F., R.E. Frank en T.M. Lodahl, Purchasing behavior and personal attributes, Philadelphia; University of Pennsylvania Press, 1968.

Massy, W.F., D.B. Montgomery en D.G. Morrison, Stochastic models of buying behavior, Cambridge, Mass.: M.I.T. Press, 1970.

McCann, J.M., "Market segment response to the marketing decision variables", Journal of Marketing Research, 11 (1974), p. 399-412.

McConnell, J.D., "The effect of pricing in an experimental setting", Journal of Applied Psychology, 52 (1968), p. 331-334.

McHale, H.P., "Correlates of brand loyalty in the automobile industry", Dissertation abstracts, 31, 6221-A (1971).

McQuarrie, E.F. en J. Munson, "The Zaichowsky Personal Involvement Inventory: modification and extension", Advances in Consumer Research, 14 (1987), p. 36-40.

Miller, J.A., "Store satisfaction and aspiration theory: A conceptual basis for studying consumer discontent", Journal of Retailing. 52 (1976), p. 65-83.

Miller, J.A., "Studying satisfaction, modifying models, eliciting expectations, posing problems and making meaningful measurements", in: H.K. Hunt (ed.), Conceptualization and measurement of consumer satisfaction and dissatisfaction, Cambridge, MA, Marketing Science Institute, 1977, p. 72-91.

Mitchell, A.A., "Involvement: a potentially important mediator of consumer behavior", Advances in Consumer Behavior, 6 (1979), p. 191-196. 
Mittal, B., "The role of affective choise made in consumer purchase of expressive products", Journal of Economic Psychology, 9 (1988), p. 499-524.

Mittal, B., "Must consumer involvement always imply more information search?", Advances in Consumer Research, 16 (1989a), p. 167-172.

Mittal, B., "A theoretical analysis of two recent measures of involvement", Advances of Consumer Research, 16 (1989b), p. 672-702.

Mittal, B., "Measuring purchase-decision involvement", Psychology and Marketing, 6 (1989c), p. 147-162.

Mittal, B. en M.S. Lee, "Seperating brand choise involvement from producer involvement via consumer involvement profiles", Advances in Consumer Research, 15 (1988), p. 36-40.

Mittal B. en M.S. Lee, "A causal model of consumer involvement", Journal of Economic Psychology, 10 (1989), p. 363-389.

Mittelstaedt, R., "A dissonance approach to repeat purchasing behavior", Journal of Marketing Research, 6 (1969), p. 444-461.

Monro, K.B. en J.P. Guiltinan, "A path analytic exploration of retail patronage influences", Journal of Consumer Research, 2 (1975), p. 19-28.

Morris, E.W., "A normative deficit approach to consumer satisfaction", in: H.K. Hunt (ed.), Conceptualization and measurement of consumer satisfaction and dissatisfaction, Cambrigde, MA, Marketing Science Institute, 1977, p. 240-274.

Morrison, D.G., "Interpurchase time and brand loyalty", Journal of Marketing Research, 3 (1966), p. 289-291.

Muncy, J.A. en S.D. Hunt, "Consumer involvement: definitional issues and research directions", Advances in Consumer Research, 11 (1984), p. 193-196.

Newman, J.W. en R.A. Werbel, "Multivariate analysis of brand loyalty for majorhousehold appliances", Journal of Marketing Research, 10 (1973), p. 404-409.

Nie, N.H., C.H. Hull, J.G. Jenkins, K. Steinbrenner en D.H. Bent, Statistical package for the Social Sciences, New York, McGraw-Hill, 1975.

Nordstrom, R.D. en J.E. Swan, "Does a change in customer loyalty occur when a new car agency is sold", Journal of Marketing Research, 13 (1976), p. 173-177.

Nunnally, J.C., Psychometric Theory, New York, McGraw-Hill, 1978, second edition.

Ölander, F., "Can consumer dissatisfaction and complaints guide public policy?", Journal of Consumer Policy, 1 (1977), p. 124-137.

Oliver, R.L., "Hedonic reactions to the disconfirmation of product performance expectations: some moderating conditions", Journal of Applied Psychology, 61 (1976), p. 246-250.

Oliver, R.L., "A theoretical reinterpretation of exceptation and disconfirnation effects on posterior product evaluations : Experiences in the field", in: R.L. Day (ed.), Consumer satisfaction, dissatisfaction and complaining behavior, Bloomington, IN, Indiana University Press, 1977, p. 2-9.

Oliver, R.L., "Product sarisfaction as a function of prior expectation and subsequent disconfirmation: New evidence". in: R. Day en K. Hunt (eds.), New dimensions of consumer satisfaction and complaining behavior, Bloomington, IN, Indiana University Press, 1979, p. 77-71.

Oliver, R.L., "A cognitive model of the antecedents and consequences of satisfaction decisions", Journal of Marketing, 17 (1980), p. $460-469$.

Oliver, R.L., "Measurement and evaluation of satisfaction processes in retail settings", Journal of Retailing, 57 (1981), p. 25-48.

Oliver, R.L., "Processing of the satisfaction response in consumption. A suggested framework and research propositions", Journal of Consumer Satisfaction/Dissatisfaction and Complaining Behavior, 2 (1989), p. $1-16$.

Oliver, R.L. en W.O. Bearden, "The role of involvement in satisfaction processes", Advances in Consumer Research, 10 (1983), p. 250-255.

Oliver, R.L. en W.S. Desarbo, "Response determinants in satisfaction judgements", Journal of Consumer Research, 14 (1988), p. 495-508.

Oliver, R.L. en G. Linda, "Effect of satisfaction and its antecedents on consumer preference and intention". Advances in Consumer Research, 8 (1981), p. 88-93.

Oliver, R.L. en J.E. Swan, "Consumer perceptions of interpersonal equity and satisfaction in transactions: a field survey approach", Journal of Marketing. 53 (1989a), p. 21-35.

Oliver, R.L. en J.E. Swan. "Equity and disconfirmation perceptions and influences on merchant and product satisfaction", Journal of Consumer Research. 16 (1989b), p. 372-383. 
Oliver, R.L. en R.A. Westbrook, "A factor structure of satisfaction and related post-purchase measures", in: R.L. Day en H.K. Hunt (eds.), New findings on consumer satisfaction and complaining behavior, Bloomington, IN, Indiana University Press, 1980, p. 11-14.

Olshavsky, R.W. en J.A. Miller, "Consumer expectations, product performance and perceived product quality", Journal of Marketing Research, 9 (1972), p. 19-21.

Olshavsky, R.W. en R.A. Spreng, "A 'desires as standard' model of consumer satisfaction", Journal of Consumer Satisfaction/Dissatisfaction and Complaining Behavior, 2 (1989), p. 49-54

Olson, J.C. en P. Dover, "Effects of expectations, product performance and disconfirmation on belief elements of cognitive structures", Advances in Consumer Research, 6 (1979), p. 179-189.

Olson, J.C. en J. Jacoby, "A construct validation study of brand loyalty", Proceedings of the American Psychological Association, 6 (1971), p. 657-658.

Oshiwaka, S., "The theory of cognitive dissonance and experimental research", Journal of Marketing Research, 15 (1968), p. 429-430.

Park, C.W. en B. Mittal, "A theory of involvement in consumer behavior: problems and issues", Research in Consumer Behavior, 1985, p. 201-229.

Park, C.W. en S.M. Young, "Types and levels of involvement and brand attitude formation", in: R.P. Bagozzi en A.M. Tybout (eds.), Advances in Consumer Research, 10 (1983), p. 320-324.

Pessemier, E.A., "A new way to determine buying decisions", Journal of Marketing, 24 (1959), p. 41-46.

Peter, J.P., "Reliability: a review of psychometric basics and recent marketing practices", Journal of Marketing Research, 16 (1979), p. 6-17.

Peter, J.P. en J.C. Olson, Consumer Behavior-Marketing Strategy Perspectives, Homewood, III: Richard D. Irwin, 1987.

Peterson, R.A. en W.R. Wilson, "Measuring customer satisfaction: fact and artifact", Journal of the Academy of Marketing Science, 20 (1992), p. 61-71.

Petty, R.E. en J.T. Cacioppo, Attitudes and persuasion: classic and contemporary approaches, Dubuque, IA: William C.Brown, 1981.

Petty, R.E. en J.T. Cacioppo, Communication and persuasion: Central and peripheral routes to attitude change, New York, Springer Verlag, 1986.

Petty, R.E., J.T. Cacioppo en D. Schumann, "Central and peripheral routes to advertising effectiveness: the moderating role of involvement", Journal of Consumer Research, 10 (1983), p. 135-146.

Pfaff, A.B., "An index of consumer satisfaction", in: M. Venkatesan (ed.), Proceedings of the Third Annual Conference of the Association for Consumer Research, 1972, p. 713-737.

Pfaff, M. en S. Blivice, "Socio-economic correlates of consumer and citizen dissatisfaction and activism", in: R.L. Day (ed.), Consumer satisfaction, dissatisfaction and complaining behavior, Bloomington, IN, Indiana University Press, 1977, p. 115- 123.

Pieters, R.G.M., B. Verplanken en J.M. Modde, "Neiging tot nadenken: Samenhang met beredeneerd gedrag", Nederlands Tijdschrift voor de Psychologie, 42 (1987), p. 62-70.

Pieters, R.G.M., Attitudes and behavior in a source-seperation program: a garbology approach, Delft, Eburon, 1989.

Poiesz, Th.B.C., "De transformatie van een karikatuur (over de ontwikkeling van het consumentbeeld in de psychologie van de reclame)", Rede ter gelegenheid van de aanvaarding van het ambt van hoogleraar, Tilburg. 1989.

Poiesz, Th.B.C. en R.G.M. Pieters, "Consumer involvement, theoretical illusion or practical act", in: P. Leeflang en M. Rice (eds.), Proceedings of the 16th Annual Conference of the European Marketing Academy. Toronto, 1987, p. wc20-wc37.

Rajaniemi, P. en M. Laaksonen, "The role of profile analysis in the conceptual development of involvement", Proceedings of the 15th Annual EMAC Conference, Helsinki, june 1986.

Raju, J.S., V. Srinivasan en R. Lal, "The effects of brand loyalty on competitive price promotional strategies", Management Science, 36 (1990), p. 276-304.

Ratchford, B.T., "New economic theory of consumer behavior: an interpretive essay", Journal of Consumer Research, 2 (1975), p. 65-78.

Ratchford, B.T., "The value of information for selected appliances", Journal of Marketing Research, 17 (1980), p. 14-25.

Ratchford, B.T., "New insight about the FCB-Grid", Journal of Advertising Research, 1987, p. 24-38.

Ratz, D.R. en D.L. Moore, "Product class involvement and purchase intent", Psychology and Marketing, 6 (1989), p. 113-127. 
Ray, S.P., "Striking a balance between brand 'popularity' and brand loyalty", Journal of Marketing, 49 (1985), p. 53-59.

Reynolds, R.D., W.R. Darden en W.S. Martin, "Developing an image of the store-loyal customer; a life style analysis to probe a neglected market", Journal of Retailing. 50 (1974/75), p. 73-84.

Reynolds, R.D. en W. D. Wells, Consumer Behavior, New York, McGraw-Hill, 1977.

Richins, M.L., "Negative word of mouth by dissatisfied consumers", Journal of Marketing. 47 (1983). p. 68-78.

Richins, M.L. en P.H. Bloch, "After the new wears off; the temporal context of productinvolvement", Journal of Consumer Research, 13 (1986), p. 280-285.

Robertson, T.S., "Low-commitment consumer behavior", Journal of AdvertisingResearch, 16 (1976), p. 19 24.

Rossiter, J.R. en L. Percey, Advertising and Promotion Management, Singapore, McGraw Hill, 1987.

Rothschild, M.L., "Perspectives on involvement: current problems and future directions", Advances in Consumer Research, 11 (1984), p. 216-217.

Rothschild, M.L. en M.J. Houston, "The consumer involvement matrix: a strategic marketing tool", Singapore Marketing Review, 1 (1986), p. 20-30.

Sherif, M. en H. Cantril, The psychology of ego-involvement, New York, Wiley, 1947.

Sherif, M. en C.J. Hovland, Social judgement; assimilation and contrast effects in communication and attitude change, New Haven, Conn., Yale University Press, 1961.

Sherif, M. en C.W. Sherif, Attitude, ego involvement and change, New York, Wiley, 1967.

Sherif, C.W., M. Sherif en R.E. Nebergall, "Attitude and attitude change", The social judgement involvement approach, New Haven: Yale University Press, 1965.

Sheth, J.N., "A factor analytic model of brand loyalty", Journal of Marketing Research, 5 (1968), p. 395-404.

Sheth, J.N., Models of buyer behovior, New York, Harper and Row, 1974.

Sheth, J.N. en M. Venkatesan, "Risk reduction process in repetitive consumer behavior", Journal of Marketing Research, 5 (1968), p. 307-310.

Sirgy, MJ., "Self-Concept in consumer behavior: a critical review", Journal of Consumer Research, 9 (1982), p. 287-300.

Sirgy, M.J., "A social cognition model of consumer satisfaction / dissatisfaction: an experiment", Psychology and Marketing, 1 (1984), p. 27-44.

Slama, M.E. en A. Tashian, "Selected socio-economic and demographic characteristics associated with purchasing involvement", Journal of Marketing, 49 (1985), p. 72-82.

Stafford, J.E., "Effect of group influences on consumer brand preferences", Journal of Marketing Research, 3 (1966), p. 68-75.

Stearns, J.M., L.S. Unger en J.A. Lesser, "Intervening variables between satisfaction/dissatisfaction and retail patronage intention", Educators Winter Conference, American Marketing Association, 1982, p. 179-182.

Sujan, M., "Consumer Knowledge: effects on evaluation strategies mediating consumer judgements", Journal of Consumer Research, 12 (1985), p. 31-46.

Swan, J.E. en S. Combs, "Product performance and consumer satisfaction: A new concept", Journal of Marketing, 40 (1976), p. 25-33.

Swan, J.E. en W.S. Martin, "Testing comparison level and predictive expectations model of satisfaction", in: B. Kent (ed.), Advances in Consumer Research, 8 (1981), p. 77-82.

Swan, J.E. en A.A. Mercer, "Consumer satisfaction as a function of equity and disconfirmation", in: H.K. Hunt en R.L. Day (eds.), Conceptual and empirical contributions to consumer satisfaction and complaining behavior, Bloomington, IN, Indiana University Press, 1982, p. 2-8.

Swan, J.E. en R.L. Oliver, "Automobile buyer satisfaction with the salesperson related to equity and disconfirmation", H.K. Hunt en R.L. Day (eds.), Consumer satisfaction, dissatisfaction and complaining behavior, Bloomington, IN, Indiana University Press, 1985, p. 10-16.

Swan, J.E. en I.F. Trawick, "Testing an extended concept of consumer satisfaction", in: R.L. Day en H.K. Hunt (eds.), New dimensions of consumer satisfaction and complaining behavior, Bloomington, $\mathbb{N}$, Indiana University Press, 1979, p. 56-61.

Swan, J.E. en I.F. Trawick, "Satisfaction related to predictive versus desired expectations", in: H.K. Hunt en R.L. Day (eds.), Refining concepts and measures of consumer satisfaction and complaining behavior, Bloomington, IN, Indiana University Press, 1980a, p. 7-13. 
Swan, J.E. en I.F. Trawick, "Inferred and percieved disconfirmation in consumer satisfaction", in: Marketing in the 80s', Proceedings of the AMA Educatiors' Conference, Chicago, 1980b, p. 97-101.

Swan, J.E. en I.F. Trawick, "Satisfaction explained by desired versus predictive expectations", Advances in Consumer Research, 8 (1981), p. 170-173.

Swan, J.D. en I.F. Trawick, "Satisfaction, disconfirmation and comparison of alternatives", in: H.K. Hunt en R.L. Day (eds.), Conceptual and empirical contributions to consumer satisfaction and complaining behavior, Bloomington, IN, Indiana University Press, 1982, p. 17-24.

Swan, J.E., I.F. Trawick en M.G. Carroll, "Effect of participation in marketing research on consumer attitudes toward research and satisfaction with a service", Journal of Marketing Research, 18 (1981), p. 356-363.

Swan, J.E., I.F. Trawick en M.G. Carroll, "Satisfaction related to predictive, desired expectations: a field study", in: R.L. Day en H.K. Hunt (eds.), New findings on consumer sarisfaction and complaining, Bloomington, IN, Indiana University Press, 1982, p. 15-22.

Tabachnik, B.G. en L.S. Fidell, Using multivariate statistics, New York, Harper and Row Publishers, 1989, second edition.

TARP: Technical Assistance Research Programs Inc., Consumer Complaint handling in America: final report, Washington D.C.: U.S. Office of Consumer Affairs, 1979.

TARP: Technical Assistance Research PTograms Inc., Consumer Complaint handling in America: An update study, Washington D.C.: U.S. Office of Consumer Affairs, contract HHS-100-84-0065, 1986.

Tellis, G.J., "Advertising exposure, loyalty and brand purchase; a two stage model of choice", Journal of Marketing Research, 25 (1988), p. 134-144.

Thibaut, J.W. en H.H. Kelly, The social psychology of groups, New York, John Wiley and Sons, 1959.

Thompson, J.W., "Brand loyalty beats price in some product categories", Marketing News, 28 (1980), p. 1.

Tolman, E.C., Purposive behavior in animals and men, New York, Appleton-Century, 1932.

Towle, J.G. en C.R. Martin Jr., "The elderly consumer; one segment or many?", in: B.B. Anderson (ed.), Advances in Consumer Research, 3 (1976), p. 463-468.

Tranberg, $H$. en F. Hansen, "Parterns of brand loyalty: their determinants and their role for leading brands", European Journal of Marketing, 30 (1986), p. 81-109.

Traylor, M.B., "Product involvement and brand commitment", Journal of Advertising Research, 21 (1981), p. 51-56.

Tse, D.K., "Attributing performance discrepance: dimensions, causes and effects", Journal of Consumer Satisfaction/Dissatisfaction and Complaining Behavior, 3 (1990), p. 105-111.

Tse, D.K. en P.C. Wilton, "Models of consumer satisfaction formation: an extension", Journal of Marketing Research. 25 (1988), p. 204-212.

Tucker, W.T., "The development of brand loyalty", Journal of Marketing Research, 1 (1964), p. 32-35.

Ulrich. D., "Tie the corporate knot: gaining complete customer commitment", Sloan Management Review, 30 (1989), p. 19-27.

Vadopivec, B., "Motivational antecedents of enduring involvement (an exploratory study)", Proceedings of the 20th European Marketing Academy Conference, Dublin, 2 (1991), p. 550-574.

Van Raaij, W.F. en Th.M.M. Verhallen, "Domein-specifieke marktsegmentatie", Tijdschrift voor Marketing. april 1990, p. 6-15.

Vaugn, R., "The consumer mind: how to tailor ad strategies", Advertising Age, 9 (1980), p. 45-46.

Veldhoven, van, G.M. "De integratie van economie en psychologie: mogelijkheden en onmogelijkheden', Economie. Sociologie en Psychologie, visies op integratie, van Assen, van Gorcum, 1987, p. 50-65.

Verplanken, B., "Involvement and need for cognition as moderators of beliefs - attitude - intention consistency", Britisch Journal of Social Psychology, 28 (1989), p. 115-122.

Verplanken, B., "Persuasive communication of risk information: a test of cue versus message processing effects in a field experiment", Personality and Social Psychology Bulletin. 17 (1991), p. 188-193.

Vezina, R. en F.M. Nicosia, "Investigations of the social determinants of consumer satisfaction en dissatisfaction", Journal of Consumer Satisfaction/Dissatisfaction and Complaining Behavior, 3 (1990), p. 36-41.

Vries, de, H.H., "Patièntentevredenheidsonderzoek en kwaliteitszorg in het Nederlandse ziekenhuis", Onderzoeksrapport 116, Instituut voor Consumentenonderzoek, Den Haag, SWOKA, 1991.

Walster, W.E., E. Bersheid en G.W. Walster, "New directions in equity research", Journal of Personality and Social Psychology, 25 (1973), p. 151-176. 
Weaver, D. en Ph. Brichman, "Expectancy, feedback and disconfirmation as independent factors in outcome satisfaction", Journal of Personality and Social Psychology, 30 (1974), p. 420-428.

Webster, F.E. (ed.), New Directions in Marketing, Chicago: American Marketing Association, 1965. p. $186-189$.

Weinberg, C.B., "The decay of brand segments", Journal of Advertising Research, 13 (1973), p. 44-47.

Weiner, B., "An attributional theory of achievement motivation and emotion", Psychological Review, 92 (1985), p. 548-573.

Weiner, B., I. Frieze, A. KukJa, L. Reed, S. Rest en R.M. Rosenbaum, Perceiving the causes of success and failure, Morristown, NJ: General Leaming Press, 1971.

Westbrook, R.A., "Correlates of post purchase satisfaction with major household appliances", in: R. Day (ed.), Consumer Satisfaction, Dissatisfaction and Complaining Behavior, Bloomington, IN, Indiana University Press, 1977, p. 85-90.

Westbrook, R.A., "Sources of consumer satisfaction with retail outlets", Journal of Retailing, 57 (1981), p. 68-85.

Westbrook, R.A., "Product/Consumption-based affective responses and postpurchase processes", Journal of Marketing Research, 24 (1987), p. 258-270.

Westbrook, R.A. en R.L. Oliver, "Developing better measures of consumer satisfaction", in: J.C. Olson (ed.), Advances in Consumer Research, 7 (1980), p. 94-99.

Westbrook, R.A. en R.L. Oliver, "The dimensionality of consumption emotion patterns and consumer satisfaction", Journal of Consumer Research, 18 (1991), p. 84-91.

Westbrook, R.A. en M.D. Reilly, "Value-percept disparity: An alternative to the disconfirmation of expectations theory of consumer satisfaction", Advances in Consumer Research, 10 (1983), p. 256-261.

Wierenga, B. en W.F. Van Raaij, Consumentengedrag; theorie, analyse en toepassingen, Leiden, Stenfert Kroese, 1987.

Williamson, O.E., "Transaction cost economics", in: R. Schmalensee en R. Willig (eds.), Handbook of industrial organizations, vol. 1. New York: Elsevier, 1989, p. 135-182.

Wilton, P.C. en D.K. Tse, "A model of consumer response to communication and product experiences", in: A. Woodside en L. Percy (eds.), Advertising and consumer psychology Lexington, Lexington Books, 1983, p. 325-332.

Winter, M. en E.W. Morris, "Satisfaction as an interviening variable", in: R.L. Day en H.K. Hunt (eds.), New dimensions of consumer satisfaction and complaining behavior, Bloomington, IN, Indiana University Press, 1979, p. 15-25.

Witteloostuijn, van, A., "Maximizing and satisficing opposite or equivalent concepts?", Journal of Economic Psychology, 9 (1988), p. 289-313.

Witteloostuijn, van, A., "Economic psychology and socio-economics; an essay on discourse strategies and research potentials", in: G.W. Antonides en W.F. Van Raaij (eds.). The consumption of time and the timing of consumption: toward a new behavioral and social economics, Amsterdam, North Holland, 1991, p. 232-242

Woodruff, R.B., E.R. Cadotte en R.L. Jenkins, "Modelling consumer satisfaction processes using experience-based norms", Journal of Marketing Research, 20 (1983), p. 296-304.

Woodside, A.G., "Positive disconfirmation of expectation and the effect of effort of evaluation", Proceedings of the 80th Annual Convention of the American Psychological Association, H.H. Kassarijan (ed.), Washington: American Psychological Association, 1972, p. 743-744.

Woodside, A.G., L.L. Frey en R.T. Daly, "Linking service quality, customer satisfaction and behavioral intention", Journal of Health Care Marketing (1989), p. 5-17.

Wright, P., "The cognitive process mediating acceptance of advertising", Journal of Marketing Research, 10 (1973), p. 53-62.

Yi, Y., "A critical review of customer satisfaction", in: V.A. Zeithaml (ed.), Review of Marketing, Chicago: American Marketing Association, 1990, p. 68-123.

Zaichowsky, J.L., "Measuring the involvement construct", Journal of Consumer Research, 12 (1985), p. 341-352.

Zaichowsky, J.L., "Conceptualization involvement", Journal of Advertising, 15 (1986), p. 4-14.

Zaltman, G. en M. Wallendorf, Consumer Behavior - basic findings and management implications, New York, John Wiley and Sons, 1983. 


\section{BIJLAGEN}

\section{BLJLAGE 1: Definities tevredenheid}

De volgende definities van tevredenheid kunnen, chronologisch gezien, in de marketingliteratuur worden aangetroffen:

'Satisfaction is the cognitive state of being adequately or inadequately rewarded in a buying situation for the sacrifices he has undergone' (Howard en Sheth, 1969 en Cardozo, 1965).

'Satisfaction is the confirmation or disconfirmation of prior expectations' (Anderson, 1973).

'The consumer is seen as a rational decision maker who seeks to maximize his total utility or overall satisfaction' (Day en Landon, 1977; Index of Consumer Satisfaction).

'Satisfaction is an evaluation rendered that the (product ownership and usage) experience was at least as good as it is supposed to be' (Hunt, 1977).

'Satisfaction is a general evaluative response to a product, perhaps not discernably different from the well-studied concept of attitude' (LaTour en Peat 1979).

'Consumer satisfaction/dissatisfaction is the outcome of a consumers' subjective comparison of expected and received product attribute levels' (Oliver, 1981).

'The surprise of finding one's pre-purchase product-specific expectations disconfirmed by postpurchase experiences with the product, and one's pre-purchase feelings toward product related experiences. A dynamic phenomenon, arising after expectancy disconfirmation and decaying over time in overall attitude' (Oliver, 1981).

'Satisfaction is an outcome of purchase and use resulting from the buyers' comparison of the rewards and costs of the purchase in relation to the anticipated consequences' (Churchill en Surprenant, 1982).

'Satisfaction is an evaluation that the chosen alternative is consistent with prior beliefs with respect to that altemative' (Engel en Blackwell, 1982).

'Satisfaction is a two dimensional construct composed of 1) the disconfirmation cognition of the product being better/worse than expected, 2) the equity cognition of a fair/unfair purchase' (Woodruff et al., 1983).

'Consumer satisfaction is the pleasurable emotional state resulting from the appraisal of a product, service, retail outlet or consumer action (a complaint, shopping trip, purchase decision etc.) as leading to or achieving one's values' (Westbrook en Reilly, 1983). 
'The consumer's response to the evaluation of the perceived discrepancy between prior expectations (or some other norm of performance) and the actual performance of the product as perceived after its consumption' (Tse en Wilton, 1988).

'Satisfaction is defined as a postconsumption evaluation that a chosen alternative at least meets or exceeds expectations' (Engel, Blackwell en Miniard, 1990).

'We see consumer satisfaction/dissatisfaction as a subjective rather than an objective process rather than a state of experiencing the purchased goods and services, through time, and within a given social environment' (Vezina en Nicosia, 1990). 


\section{BLJLAGE 2: Definities van involvement}

De volgende definities van involvement kunnen, chronologisch gezien, in de marketingliteratuur worden aangetroffen:

'The number of concious bridging experiences, connections or personal references per minute that the viewer makes between his own life and the stimulus' (Krugman, 1965).

'An internal state variable that indicates the amount or arousal, interest, or drive evoked by a particular stimulus or situation' (Mitchell, 1979 en 1981, te vergelijken met Bloch, 1983).

'Involvement is the variation in the extent to which individuals are more or less motivated toward specific information, product/service or the alike' (Hansen, 1981).

'Involvement is perceived product importance' (Traylor, 1981; Lastovicka en Bonfield, 1982).

'Involvement is said to reflect the extent of personal relevance of the decision to the individual in terms of her basic values, goals and self concept' (Engel en Blackwell, 1982; te vergelijken met Celsi en Olson, 1989).

'Involvement may be thought of as te motivational state that results from the stimulus or product importance perceptions' (Bloch en Richins, 1983).

'A person's activation level at a particular moment of time' (Cohen, 1983).

'There is a consensus that high involvement means (approximately) personal relevance or importance' (Greenwald en Leavitt, 1984).

'Involvement is the level of perceived personal importance and/or interest evoked by a stimulus (or stimuli) within a specific stituation' (Antil, 1984).

'Involvement is an unobservable state of motivation, arousal or interest. It is evoked by a particular stimulus of situation and has drive properties. Its consequences are types of searching, information processing and decisionmaking' (Rothshild, 1984).

'Involvement is the interest in the product category' (Hansen, 1985).

'A goal directed arousal capacity' (Park en Mittal, 1985).

'Involvement is a person's perceived relevance of the object, based on inherent needs, values and interests' (Zaichowsky, 1985).

'The motivational state of a consumer in a brand choice task, reflecting how motivated (or aroused) the consumer is to make a good choice' (Mittal, 1988).

'Involvement is the perceived value of a 'goal-object' that manifests as interest in that 'goalobject'. This goal-object can be the product itself (as in product involvement) or the purchase decision (as in brand decision involvement)' (Mittal en Lee, 1989).

'Involvement, then, is a reflection of strong motivation in the form of high perceived personal relevance of a product or service in a particular context' (Engel, Blackwell en Miniard, 1990). 
BLJLAGE 3: Items Likert-schaal voor het meten van commitment

Onderstaand wordt een overzicht gegeven van de oorspronkelijke commitment-items. Tevens worden de vertaling ervan in het Nederlands en de herkomst van het item aangegeven.

1* I consider myself to be highly loyal to one brand of soft drink

Ik vind mezelf zeer trouw ten opzichte van een bepaald merk frisdrank.

(Beatty et al., 1988)

2* When another brand is on sale, I will generally purchase it, rather than my usual brand Wanneer een ander merk frisdrank in de aanbieding is, koop ik dat eerder dan mijn gebruikelijke merk.

(Beatty et al., 1988)

3* If my preferred brand or type of soft drink were not available at the store, it would make little difference to me if I had to choose another brand

Wanneer het merk frisdrank waaraan ik de voorkeur geef niet verkrijgbaar is in de winkel dan koop ik een willekeurig ander merk dat wel verkrijgbaar is.

(Beatty et al., 1988 vgl. Lastovicka en Gardner, 1977 en Mittal en Lee, 1989)

4* If my preferred brand of soft drink is not available in the store, I will buy another favorite brand

Wanneer het merk frisdrank waaraan ik de voorkeur geef niet verkrijgbaar is in de winkel dan koop ik een ander merk dat ik net zo goed vind.

(Mittal en Lee, 1989)

5* If my preferred brand of soft drink is not available in the store, I will go to another store Wanneer het merk frisdrank waaraan ik de voorkeur geef niet verkrijgbaar is in de winkel dan ga ik naar een andere winkel om het daar te kopen.

(Mittal en Lee, 1989)

6* If I had made a brand choice in this product class before actually making the purchase, I might easily change my intended choice upon receiving discrepant information

Als ik van plan ben een bepaald merk frisdrank te kopen, is het nog gemakkelijk om mij van gedachten te doen veranderen en feitelijk een ander merk te kopen.

(Lastovicka en Gardner, 1977)

7 If I received information that was contrary to my choice in this product class, I would at all costs keep my choice

Wanneer ik informatie krijg die mijn aanvankelijke keuze voor een bepaald merk niet ondersteund, doe ik alles om toch bij mijn oorspronkelijke keuze te blijven.

(Lastovicka en Gardner, 1977)

*: item is opgenomen in de definitieve schaal 
Per item wordt zo nauwkeurig mogelijk aangegeven waar dit vandaan komt en wat de vraag wordt verondersteld te meten. Indien dit laatste niet staat vermeld, betekent dit dat de vraag algemene, cognitieve merkkeuze involvement verondersteld wordt te meten.

1* Choosing a beer is an important decision for me

De keuze van een bepaald merk frisdrank is voor mij niet belangrijk.

(Mittal en Lee, 1988; perceived importance)

2* Feeling involved in the matter

Ik voel me niet betrokken bij de merkkeuze van frisdrank.

(Verplanken, 1991; affectief)

3 A lot to lose if you choose the wrong brand - little to lose if you choose the wrong brand Ik heb niet veel te verliezen wanneer ik het verkeerde merk frisdrank kies.

(Ratchford, 1987; perceived risk)

4 Thinking about the issue

Ik denk goed na voor ik een bepaald merk frisdrank kies.

(Verplanken, 1991)

5* I have a strong interest in.......

Ik ben erg geînteresseerd in het kiezen van het juiste merk frisdrank.

(Laurent en Kapferer, 1985; interest)

6* I choose my beer very carefully

Ik kies zorgvuldig een bepaald merk frisdrank uit.

(Mittal en Lee, 1988; perceived importance)

7* For me, ...... do not matter

Het kan me niet schelen welk merk frisdrank ik kies.

(Mittal, 1989c; Mittal en Lee, 1989)

8* I would not care at all as to which one I buy - I would care a great deal as to which one I buy

Ik neem de keuze van een merk frisdrank serieus.

(Mittal, 1989)

9* It was important to my choice that the university campus 'felt' right when I walked around it

Het is voor mij niet belangrijk dat ik me tevreden voel bij de keuze van een bepaald merk frisdrank.

(Cullen en Edgett, 1991; affectief)

10 It was important to my choice that the university campus 'felt' right when I walked around it

Het is belangrijk voor mij dat ik wanneer ik een bepaald merk frisdrank kies, ik het gevoel heb dat ik een juiste keuze heb gemaakt.

(Cullen en Edgett, 1991; affectief) 
11 I picked this university because it seemed to fit with my personality Ik kies altijd het merk frisdrank dat het best bij mijn persoonlijkheid past.

(Cullen en Edgett, 1991; affectief)

12* They are all alike - they are all different

Het maakt geen verschil welk bepaald merk frisdrank je kiest.

(Mittal, 1989c)

13 Judging someone by the beer he/she drinks would be a mistake

Iemand beoordelen aan de hand van het merk frisdrank dat hij/zij kiest, zou een vergissing zijn.

(Mittal en Lee, 1988; sign value)

14 The academic reputations of the university was important in deciding which university to go to

De reputatie van een merk is belangrijk voor mij bij de keuze van een bepaald merk frisdrank.

(Cullen en Edgett, 1991; cognitief)

15 There are many different factors to consider when deciding which university to attend

Er zijn veel verschillende factoren die ik in overweging neem wanneer ik een bepaald merk frisdrank kies.

(Cullen en Edgett, 1991; cognitief)

16 The 'prestige' of the university was very important to me in making a choice of universities

Het 'prestige' van een merk is niet belangrijk voor mij bij de keuze van een specifiek merk frisdrank.

(Cullen en Edgett, 1991; cognitief)

17* Personal relevance of .......

Persoonlijk is voor mij de keuze van een bepaald merk frisdrank niet relevant.

(Verplanken, 1991)

18 Which beer I drink matter to me a lot

Welk merk frisdrank ik kies, betekent veel voor me.

(Mittal en Lee, 1988; perceived importance)

19 When you buy a beer, it is not a big deal if you buy a wrong brand by mistake

Wanneer ik een bepaald merk frisdrank kies, is het belangrijk dat ik het juiste merk frisdrank heb gekozen.

(Mittal en Lee, 1988; perceived risk)

20* A bad buy of beer could bring you grief

Van de keuze van een verkeerd merk frisdrank, heb ik spijt.

(Mittal en Lee, 1988; perceived risk)

21 When you buy a beer, it is hard to make a bad choice

Wanneer je een merk frisdrank koopt, is het moeilijk om een verkeerd merk te kiezen.

(Mittal en Lee, 1988; perceived risk) 
22 You can really tell about a person by the beer he or she picks

Je kunt veel over een persoon zeggen, wanneer je weet welk merk frisdrank hij/zij kiest.

(Mittal en Lee, 1988; sign value)

23* Not at all concerned - very much concerned

Ik maak me niet druk over welk merk frisdrank ik kies.

(Mittal, 1989)

24 You are what beer you drink

Je bent het merk frisdrank dat je kiest, zoals kleren de man maken.

(Mittal en Lee, 1988; sign value)

25 The beer I usually drink is the most enjoyable of all

Het merk frisdrank dat ik kies, is het merk waar je het meest van kunt genieten.

(Mittal en Lee, 1988; hedonic value)

26 I just couldn't indulge myself as much with other beers as with the brand I drink often Ik zou mezelf met een ander merk frisdrank lang niet zo'n plezier doen als met dit merk.

(Mittal en Lee, 1988; hedonic value)

27 When I purchase a ....., I am never sure of my choice

Wanneer ik een blikje frisdrank kies, ben ik eigenlijk nooit zeker van mijn keuze.

(Laurent en Kapferer, 1985; risk probability)

28 When I face a shell of ...., I always feel a bit at a loss to make my choice

Wanneer ik naar het aanbod van frisdrank kijk, vind ik het moeilijk om een keuze te maken.

(Laurent en Kapferer, 1985; risk probability)

*: item is opgenomen in de definitieve schaal 
Onderstaand wordt een overzicht gegeven van de oorspronkelijke involvement-items. Tevens worden de vertaling ervan naar het Nederlands, de herkomst van het item en voor zover bekend de door het item vertegenwoordigde dimensie van involvement, genoemd.

1 important - unimportant

belangrijk - onbelangrijk

(Zaichowsky, 1985; importance)

2 of no concern - of concern to me

gewichtig - niet gewichtig

(Zaichowsky, 1985; importance)

3 irrelevant - relevant

irrelevant - relevant

(Zaichowsky, 1985; importance)

4 means a lot to me - means nothing to me betekent veel voor me - betekent niets voor me (Zaichowsky, 1985; importance)

5 useless - useful niet nuttig - nuttig

(Zaichowsky, 1985; attitude?)

6 valuable - worthless waardevol - waardeloos (Zaichowsky, 1985; attitude?)

7 trivial - fundamental oppervlakkig - diepgaand (Zaichowsky, 1985; attitude?)

8 beneficial - not benificial kent voordelen - kent nadelen (Zaichowsky, 1985; attitude?)

9 matters to me - doesn't matter doet me iets - doet me niets (Zaichowsky, 1985; importance)

10 uninterested - interested oninteressant - interessant (Zaichowsky, 1985; attitude?)

11 significant - insignificant betekenisvol - zonder betekenis (Zaichowsky, 1985; attitude?) 
12 vital - superfluous

essentieel - overbodig

(Zaichowsky, 1985; attitude?)

13 boring - interesting vervelend - interessant

(Zaichowsky, 1985; pleasure)

14 unexiting - exiting

niet opwindend - opwindend

(Zaichowsky, 1985; pleasure; affectief)

15 appealing - unappealing

aantrekkelijk - onaantrekkelijk

(Zaichowsky, 1985; affectief; pleasure)

16 mudane - fascinating

saai - fascinerend

(Zaichowsky, 1985; attitude?; affectief)

17 essential - nonessential

wezenlijk - niet wezenlijk

(Zaichowsky, 1985; attitude?)

18 wanted - unwanted

onontbeerlijk - ontbeerlijk

(Zaichowsky, 1985; attitude?)

19 undesirable - desirable

gewenst - ongewenst

(Zaichowsky, 1985; attitude?)

20 not needed - needed

niet noodzakelijk - noodzakelijk

(Zaichowsky, 1985; attitude?)

21 no risk - risky

risicovol - zonder risico

(McQuarrie en Munson, 1987; risk)

22 easy to go wrong - hard to go wrong

moeilijk - makkelijk

(McQuarrie en Munson, 1987; risk)

23 hard to pick - easy to choose

eenvoudig - ingewikkeld

(McQuarrie en Munson; 1987; risk)

24 fun - no fun

plezierig - onplezierig

(McQuarrie en Munson, 1987; pleasure) 
25 says something about me - says nothing about me zegt iets over mezelf - zegt niets over mezelf

(McQuarrie en Munson, 1987: sign value)

26 tells me about a person - shows nothing zegt niets over een persoon - zegt iets over een persoon (McQuarrie en Munson, 1987; sign value)

27 heeds owner's wishes - choose whatever I want verraadt wensen - verraadt niets

(McQuarrie en Munson, 1987; sign value)

28 my own business - important to others belangrijk voor anderen - alleen voor mij van belang (McQuarrie en Munson, 1987, sign value) 
BLJLAGE 6: Correlatie-analyse van commitment-, merkkeuze-involvement- en deliberatieitems (vooronderzoek)

\section{Cassettebandjes}

Merkkeuze-involvement $(01201 \mathrm{t} / \mathrm{m}$ 01223) x Commitment $(01401 \mathrm{t} / \mathrm{m} 01406)$

(laatste twee cijfers komen overeen met itemnr. in tabel van de schaal in hoofdstuk 5)

\begin{tabular}{|c|c|c|c|c|c|c|}
\hline Correlatie: & 01401 & 01402 & 01403 & 01404 & 01405 & 01406 \\
\hline $\begin{array}{l}01201 \\
01202 \\
01205 \\
01206 \\
01207 \\
01208 \\
01209 \\
01212 \\
01217 \\
01220 \\
01223\end{array}$ & $\begin{array}{l}.3458 * \star \\
.3744^{\star} \star \\
.3283^{\star} \\
.3261 * \\
.5014^{*} \\
.3565 * \\
.3023^{\star} \\
.3459 * \\
.2471 \\
.2877 \star \\
.3407 *\end{array}$ & 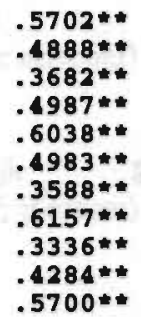 & 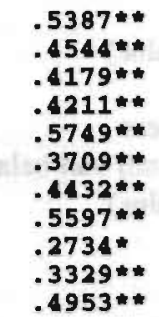 & $\begin{array}{l}.3316^{\star} \\
.3020^{*} \\
.2982^{*} \\
.3301 * \\
.3421 * \\
.3570^{*} \\
.1801 \\
.2391 \\
.1948 \\
.2676 * \\
.3653 *\end{array}$ & $\begin{array}{l}.4659 * \star \\
.3825 * \star \\
.4293^{*} \\
.4191 * \\
.5161 * \star \\
.4505 * * \\
.4101 * \star \\
.4472 * * \\
.3946 * \\
.3870 * \\
.5068 *\end{array}$ & $\begin{array}{l}.5492 * \star \\
.4855 * * \\
.4839 * * \\
.5707 * \star \\
.5892 * * \\
.5967 * \star \\
.3419 * * \\
.4813 * * \\
.3593 * \star \\
.3308 * \\
.4419 * *\end{array}$ \\
\hline
\end{tabular}

$\mathrm{n}=87 ;{ }^{*} \mathrm{p}<.01 ;{ }^{* *} \mathrm{p}<.001$

Merkkeuze-involvement $(01201 \mathrm{t} / \mathrm{m}$ 01223) x Deliberatie (01408 t/m 01413)

(laatste twee cijfers komen overeen met itemnr. in tabel van de schaal in hoofdstuk 5 ,

met uitzondering van deliberatie; hiervoor geld 08=itemnr 1, 09=itemnr 2 enz.)

\begin{tabular}{lcccccc}
\hline Correlat1e: & 01408 & 01409 & 01410 & 01411 & 01412 & 01413 \\
\hline 01201 & .1137 & .0344 & .0104 & -.0346 & .1477 & .0950 \\
01202 & -.0098 & -.0504 & .0287 & -.0872 & .1200 & .0867 \\
01205 & .2091 & .1577 & .1567 & .1099 & .1833 & .0823 \\
01206 & .1333 & .1751 & .1691 & .1972 & .1986 & .1146 \\
01207 & .1719 & .0328 & .0574 & .0673 & .0805 & -.0361 \\
01208 & .0897 & .1601 & .1355 & .0834 & .1721 & .1573 \\
01209 & .0870 & .0939 & .2029 & .1789 & .1752 & .2408 \\
01212 & -.0492 & -.0232 & .0387 & -.0802 & .0638 & .0660 \\
01217 & .0593 & .2041 & $.2641 *$ & .2029 & -.0189 & .0338 \\
01220 & -.0352 & .1342 & .0547 & .0137 & .1134 & .0460 \\
01223 & .0167 & .0203 & .0203 & .0194 & .1422 & .0147 \\
\hline
\end{tabular}

$\mathrm{n}=84 ;{ }^{*}: \mathrm{p}<.01 ; * *$ p $<.001$

Commitment $(01401 \mathrm{t} / \mathrm{m}$ 01406) $\times$ Deliberatie $(01408 \mathrm{t} / \mathrm{m}$ 01413)

(laatste twee cijfers komen overeen met itemnr. in tabel van de schaal in hoofdstuk 5 . met uitzondering van deliberatie; hiervoor geld $08=$ itemnr 1,09=itemn 2 enz.)

\begin{tabular}{lcccccc}
\hline Correlat1e: & 01408 & 01409 & 01410 & 01411 & 01412 & 01413 \\
\hline 01401 & -.0852 & -.1080 & -.0565 & -.0961 & -.0401 & -.0335 \\
01402 & -.1089 & -.1055 & -.0299 & -.1112 & .0273 & .0320 \\
01403 & .0855 & .0584 & .0721 & .0755 & .1863 & .2677 \\
01404 & .1039 & -.0132 & -.0730 & .0002 & .0749 & .0629 \\
01405 & .0627 & .1101 & .0249 & .0949 & .1235 & .1296 \\
01406 & .0660 & .0771 & .0339 & .0392 & .2361 & .1926 \\
\hline
\end{tabular}

$\mathbf{n}=88 ;{ }^{*}$ p<.01; **: p<.001 
Merkkeuze-involvement (02201 t/m 01223) x Commitment (02401 t/m 02406) (laaste twee cijfers komen overeen met itemnr. in tabel van de schaal in hoofdstuk 5)

\begin{tabular}{|c|c|c|c|c|c|c|}
\hline Correlatte: & 02401 & 02402 & 02403 & 02404 & 02405 & 02406 \\
\hline $\begin{array}{l}02201 \\
02202 \\
02205 \\
02206 \\
02207 \\
02208 \\
02209 \\
02212 \\
02217 \\
02220 \\
02223\end{array}$ & $\begin{array}{l}.3748 * \\
.3432 * \star \\
.3452 * \\
.5285 * \\
.4668 * \\
.4430 * \\
.2044 \\
.4261 * \\
.3686 * \\
.3639 * \\
.4304 * *\end{array}$ & 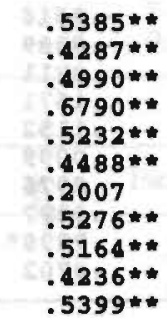 & $\begin{array}{l}.2770^{\star} \\
.1928 \\
.2348 \\
.4963^{*} \\
.3167 * \\
.2952^{\star} \\
.1375 \\
.3525 * \\
.4137^{*} \\
.1639 \\
.2995^{*}\end{array}$ & $\begin{array}{l}.1712 \\
.1280 \\
.3545 * \\
.3884 \\
.2326 \\
.2103 \\
.0843 \\
.2376 \\
.2607 \\
.1042 \\
.2322\end{array}$ & $\begin{array}{l}.4650^{* *} \\
.3717^{*} \\
.3844^{*} \\
.5854^{*} \\
.5087^{*} \\
.4872^{*} \\
.3254^{*} \\
.5134^{*} \\
.5013^{*} \\
.2909^{*} \\
.4278^{*}\end{array}$ & $\begin{array}{l}.4907 * \star \\
.3599 * * \\
.4754 * \star \\
.5712 * \star \\
.4825 * * \\
.4571 * \star \\
.0489 \\
.5022 * \star \\
.4584 * \\
.3666 * \\
.4340 *\end{array}$ \\
\hline
\end{tabular}

$\mathrm{n}=87 ; *: \mathrm{p}<.01 ; * *: \mathrm{p}<.001$

Merkkeuze-involvement (02201 t/m 02223) x Deliberatie (02408 t/m 02413)

(laatste twee cijfers komen overeen met itemnr. in tabel van de schaal in hoofdstuk 5 , met uitzondering van deliberatie; hiervoor geld $08=$ itemnr 1, 09=itemnr 2 enz.)

\begin{tabular}{|c|c|c|c|c|c|c|}
\hline Correlatie: & 02408 & 02409 & 02410 & 02411 & 02412 & 02413 \\
\hline $\begin{array}{l}02201 \\
02202 \\
02205 \\
02206 \\
02207 \\
02208 \\
02209 \\
02212 \\
02217 \\
02220 \\
02223\end{array}$ & $\begin{array}{l}.2819 * \\
.2121 \\
.3132 * \\
.3975 * \\
.3505 * \\
.4206 * \\
.2022 \\
.4155 * \\
.4717 * \\
.2784 \\
.3670 *\end{array}$ & $\begin{array}{c}.1759 \\
.1661 \\
.2136 \\
.2104 \\
.2426 \\
.1517 \\
-.0864 \\
.3233 * \\
.2882 \\
.1578 \\
.2106\end{array}$ & $\begin{array}{l}.2643^{\star} \\
.2021 \\
.3159^{\star} \\
.1679 \\
.2654 * \\
.2773^{\star} \\
.0955 \\
.2636 * \\
.3577 * \\
.2153 \\
.1768\end{array}$ & $\begin{array}{r}.0858 \\
.0706 \\
.1379 \\
.0994 \\
.1535 \\
.0904 \\
-.0112 \\
.1782 \\
.2357 \\
.2058 \\
.0851\end{array}$ & $\begin{array}{r}-.0653 \\
-.0640 \\
.0147 \\
-.0613 \\
-.0121 \\
-.0495 \\
-.1632 \\
.1658 \\
.1242 \\
-.0479 \\
.1473\end{array}$ & $\begin{array}{r}-.0085 \\
-.0114 \\
.1273 \\
.1529 \\
.0910 \\
.0472 \\
.1474 \\
.0909 \\
.1952 \\
.1965 \\
.1318\end{array}$ \\
\hline
\end{tabular}

$\mathrm{n}=85 ;{ }^{*}: \mathrm{p}<.01 ; * *: \mathrm{p}<.001$

Commitment $(02401 \mathrm{t} / \mathrm{m}$ 02406) x Deliberatie (02408 t/m 02413)

(laatste twee cijfers komen overeen met itemnr. in tabel van de schaal in hoofdstuk 5 . met uitzondering van deliberatie; hiervoor geld $08=$ itemnr 1, 09=itemnr 2 enz.)

\begin{tabular}{llllllr}
\hline Correlatie: & 02408 & 02409 & 02410 & 02411 & 02412 & \multicolumn{1}{c}{02413} \\
\hline 02401 & $.2884 *$ & $.2559 *$ & -.0394 & -.0460 & .0629 & -.0310 \\
02402 & $.4078 *$ & $.2913 *$ & .2105 & .0214 & .1785 & .1736 \\
02403 & $.374 * *$ & .1788 & .0401 & .1593 & .1194 & .1583 \\
02404 & .1904 & .2206 & .0164 & -.0321 & .1441 & -.0247 \\
02405 & $.3431^{*}$ & $.2695 *$ & .0322 & .0497 & .0628 & .1781 \\
02406 & $.2939 *$ & .2068 & .2331 & .1574 & .1113 & .1876 \\
\hline
\end{tabular}

$\mathrm{n}=86 ;{ }^{*} \mathrm{p}<.01 ; * * \mathrm{p}<.001$ 
Frisdrank

Merkkeuze-involvement (03201 t/m 03223) x Commitment (03401 t/m 03406)

(laatste twee cijfers komen overeen met itemnr. in tabel van de schaal in hoofdstuk 5)

\begin{tabular}{|c|c|c|c|c|c|c|}
\hline Correlat1e: & 03401 & 03402 & 03403 & 03404 & 03405 & 03406 \\
\hline $\begin{array}{l}03201 \\
03202 \\
03205 \\
03206 \\
03207 \\
03208 \\
03209 \\
03212 \\
03217 \\
03220 \\
03223\end{array}$ & $\begin{array}{l}.4546 * \\
.4194 * \\
.1976 \\
.2967 * \\
.4105 * * \\
.3467 * \\
.1947 \\
.2452 * \\
.2906 * \\
.1452 \\
.4027\end{array}$ & 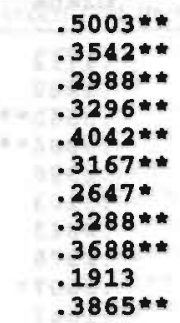 & $\begin{array}{l}.4236 * \\
.3660^{*} \\
.2385 \\
.3060^{*} \\
.3149^{*} \\
.3209^{*} \\
.2765 * \\
.2364 \\
.1755 \\
.2660^{*} \\
.2942^{\star}\end{array}$ & $\begin{array}{l}.1287 \\
-.0516 \\
-.0389 \\
.0211 \\
.1671 \\
.1152 \\
.0099 \\
.0976 \\
.0377 \\
.2299 \\
.0702\end{array}$ & $\begin{array}{l}.1980 \\
.1196 \\
.1649 \\
.0622 \\
.1558 \\
.1228 \\
.2656 \\
.1879 \\
.0443 \\
.2430 \\
.1939\end{array}$ & $\begin{array}{l}.4020 * * \\
.2811^{*} \\
.2943^{\star} \\
.3621 \\
.4061 * \\
.3028 * \\
.2986 * \\
.2663^{*} \\
.2338^{\star} \\
.2193^{*} \\
.2517 *\end{array}$ \\
\hline
\end{tabular}

$\mathrm{n}=127 ; * \mathrm{p}<.01 ; * *: \mathrm{p}<.001$

Merkkeuze-involvement $(03201 \mathrm{t} / \mathrm{m}$ 03223) x Deliberatie (03408 t/m 03413)

(laatste twee cijfers komen overeen met itemnr. in tabel van de schaal in hoofdstuk 5 , met uitzondering van deliberatie; hiervoor geld 08=itemnr 1, 09=itemnr 2 enz.)

\begin{tabular}{lllllll}
\hline Correlatiet & 03408 & 03409 & 03410 & 03411 & 03412 & 03413 \\
\hline 03201 & .0568 & -.0220 & -.0876 & -.0055 & .0414 & -.0502 \\
03202 & $.2397 *$ & .1023 & .1973 & .1579 & .1615 & .1216 \\
03205 & $.2874 *$ & .2044 & $.2756 *$ & .2097 & .1900 & .1613 \\
03206 & $.2353 *$ & .1189 & .1812 & .1193 & .1521 & .0880 \\
03207 & .0204 & .0103 & .0835 & -.0328 & .0358 & -.0427 \\
03208 & $.2508 *$ & .1925 & .1775 & .1822 & .1410 & .1086 \\
03209 & .2083 & .1018 & .1088 & .0588 & .1213 & .0897 \\
03212 & .1199 & .0690 & .0672 & .0431 & .0695 & .1065 \\
03217 & .1233 & .0607 & .1550 & .1648 & .0915 & .1701 \\
03220 & $.2832 * *$ & .1625 & .1810 & $.2232 *$ & .1814 & $.3147 *$ \\
03223 & .2084 & .1909 & .1439 & .2004 & $.2177 *$ & $.2362 *$ \\
\hline
\end{tabular}

$n=122 ; *: p<.011^{* *}: p<.001$

Commitment $(03401 \mathrm{t} / \mathrm{m}$ 03406) $\times$ Deliberatie (03408 $\mathrm{t} / \mathrm{m}$ 03413)

(laatste twee cijfers komen overeen met itemnr. in tabel van de schaal in hoofdstuk 5 , met uitzondering van deliberatie; hiervoor geld 08=itemnr 1,09=itemnr 2 enz.)

\begin{tabular}{lcccccc}
\hline Correlat1e: & 03408 & 03409 & 03410 & 03411 & 03412 & 03413 \\
\hline 03401 & .0654 & .0760 & .0624 & .0097 & .1244 & -.0089 \\
03402 & .1297 & -.0287 & -.0021 & .0651 & .0616 & -.0202 \\
03403 & .1063 & -.0178 & -.0070 & -.0243 & .0426 & -.0248 \\
03404 & .1822 & .0885 & -.2004 & .1053 & .1667 & .0918 \\
03405 & $.3760 *$ & .1690 & .0228 & $.2687 *$ & $.2185 \star$ & $.2456 \star$ \\
03406 & .1319 & .0698 & .0704 & .0487 & .1757 & .0290 \\
\hline
\end{tabular}

n $=124 ; *: p<.01 ; * *: p<.001$ 
BIJLAGE 7: Factoranalyse merkkeuze-involvement (Likertschaal); PCA; varimax rotatie

\section{BIJLAGE 7.1: $\quad$ Cassettebandjes}

\begin{tabular}{llll}
\hline Factor & Eigenwaarde & Perc Var & Cum Perc \\
\hline 1 & 5.39 & 49.0 & 49.0 \\
2 & 1.05 & 9.5 & 58.5 \\
3 & 1.02 & 9.3 & 67.8 \\
\hline Geroteerde Factor Matrix: & & \\
\hline Item & Factor 1 & Factor 2 & Factor 3 \\
\hline 1 & .84 & .21 & .19 \\
2 & .74 & .17 & .11 \\
5 & .12 & .78 & .20 \\
6 & .39 & .77 & .10 \\
7 & .72 & .42 & .14 \\
8 & .19 & .76 & .25 \\
9 & .20 & .13 & .88 \\
12 & .75 & .17 & .34 \\
17 & .44 & .52 & .09 \\
20 & .22 & .28 & .80 \\
23 & .49 & .31 & .40 \\
\hline
\end{tabular}

\section{BIJLAGE 7.2: Jeans}

\begin{tabular}{llll}
\hline Factor & Eigenwaarde & Perc Var & Cum Perc \\
\hline 1 & 7.11 & 64.6 & 64.6 \\
\hline
\end{tabular}

Geroteerde Factor Matrix:

\begin{tabular}{ll}
\hline Item & Factor 1 \\
\hline 1 & .80 \\
2 & .77 \\
5 & .83 \\
6 & .84 \\
7 & .89 \\
8 & .84 \\
9 & .52 \\
12 & .83 \\
17 & .88 \\
20 & .74 \\
23 & .83 \\
\hline
\end{tabular}


Frisdrank

\begin{tabular}{llll}
\hline Factor & Eigenwaarde & Perc Var & Cum Perc \\
\hline 1 & 5.36 & 48.7 & 48.7 \\
2 & 1.22 & 11.1 & 59.8 \\
\hline Geroteerde & Factor Matrix: & & \\
\hline Item & Factor 1 & Factor 2 & \\
\hline 1 & .78 & .19 & \\
2 & .62 & .46 & \\
5 & .82 & .16 & \\
6 & .83 & .14 & \\
7 & .69 & .40 & \\
8 & .67 & .39 & \\
9 & .24 & .60 & \\
12 & .40 & .67 & \\
17 & .26 & .66 & \\
20 & .01 & .76 & \\
23 & .32 & .70 & \\
\hline
\end{tabular}


BLJLAGE 8: Factoranalyse merkkeuze-involvement (semantische differentiaal); PCA; varimax rotatie

BIJLAGE 8.1: Cassettebandjes

\begin{tabular}{llll}
\hline Factor & Eigenwaarde & Perc Var & Cum Perc \\
\hline 1 & 7.75 & 36.9 & 36.9 \\
2 & 2.54 & 12.1 & 49.0 \\
3 & 1.49 & 7.1 & 56.1 \\
4 & 1.12 & 5.3 & 61.5 \\
5 & 1.10 & 5.2 & 66.7 \\
\hline
\end{tabular}

Geroteerde Factor Matrix:

\begin{tabular}{llllll}
\hline Item & Factor 1 & Factor 2 & Factor 3 & Factor 4 & Factor 5 \\
\hline 1 & .69 & .24 & .06 & .44 & .03 \\
2 & .50 & .36 & -.03 & .50 & .11 \\
3 & .75 & .04 & -.04 & .33 & .08 \\
4 & .57 & .39 & .10 & .48 & .04 \\
5 & .73 & .10 & .22 & .14 & .10 \\
7 & .11 & -.02 & .33 & .75 & .10 \\
9 & .21 & .48 & .15 & .36 & .22 \\
10 & .04 & .18 & .55 & .61 & .25 \\
11 & .19 & .44 & .41 & .35 & .21 \\
12 & .81 & .08 & .25 & -.12 & .08 \\
13 & .19 & .14 & .81 & .11 & -.05 \\
14 & .16 & .41 & .37 & .31 & .51 \\
15 & -.06 & .17 & .30 & .02 & .76 \\
16 & .26 & .16 & .66 & .21 & .35 \\
17 & .41 & .07 & -.06 & .18 & .73 \\
19 & .66 & .01 & .47 & -.09 & .01 \\
20 & .70 & .03 & .04 & .03 & .07 \\
24 & .04 & .27 & .66 & .22 & .24 \\
25 & .13 & .78 & .15 & .17 & .22 \\
26 & -.01 & .86 & .06 & -.06 & .11 \\
27 & .11 & .61 & .26 & .24 & -.12 \\
\hline
\end{tabular}


BLJLAGE 8.2: Jeans

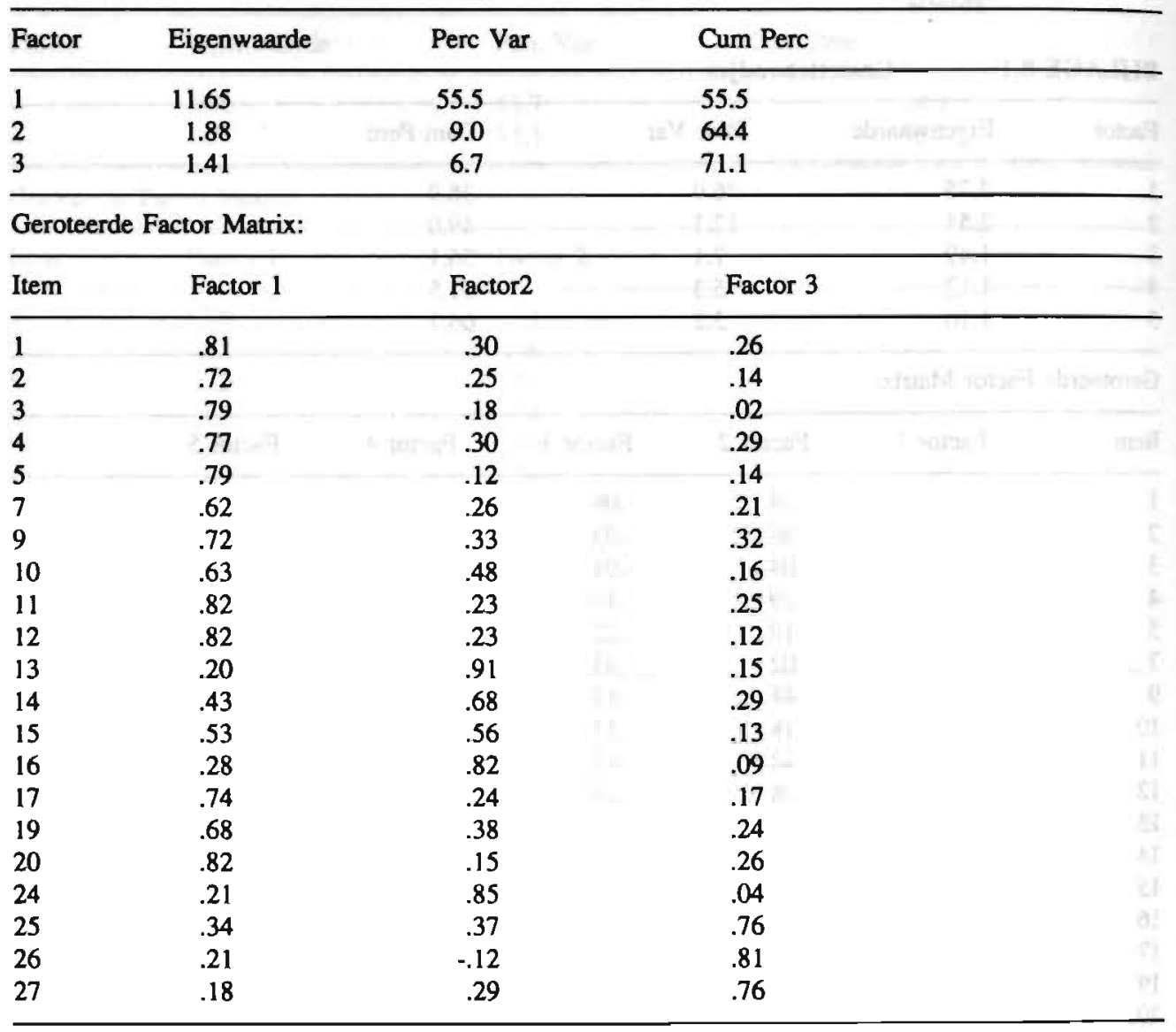


BIJLAGE 8.3: Frisdrank

\begin{tabular}{llll}
\hline Factor & Eigenwaarde & Perc Var & Cum Perc \\
\hline 1 & 10.67 & 50.8 & 50.8 \\
2 & 1.79 & 8.5 & 59.4 \\
3 & 1.45 & 6.9 & 66.2 \\
\hline
\end{tabular}

Geroteerde Factor Matrix:

\begin{tabular}{llll}
\hline Item & Factor 1 & Factor 2 & Factor 3 \\
\hline 1 & .24 & .77 & .26 \\
2 & .46 & .50 & .35 \\
3 & .24 & .78 & .15 \\
4 & .46 & .52 & .45 \\
5 & .08 & .78 & .15 \\
7 & .63 & .42 & .18 \\
9 & .67 & .33 & .35 \\
10 & .78 & .34 & .19 \\
11 & .51 & .49 & .28 \\
12 & .40 & .73 & .11 \\
13 & .79 & .27 & .13 \\
14 & .74 & .28 & .32 \\
15 & .83 & .21 & .18 \\
16 & .84 & .15 & .15 \\
17 & .48 & .63 & .79 \\
19 & .25 & .74 &. .05 \\
20 & .33 & .56 & .15 \\
24 & .62 & .28 & .17 \\
25 & .29 & .17 & .83 \\
26 & .17 & .13 & .81 \\
27 & .18 & .11 & .76 \\
\hline
\end{tabular}


BLJLAGE 9: Factoranalyse alle items (Likertschalen); PCA; varimax rotatie; $\max 3$ factoren BIJLAGE 9.1: Cassettebandjes

\begin{tabular}{llll}
\hline Factor & Eigenwaarde & Perc Var & Cum Perc \\
\hline 1 & 9.00 & 39.1 & 39.1 \\
2 & 3.35 & 14.5 & 53.7 \\
3 & 1.49 & 6.5 & 60.2 \\
\hline
\end{tabular}

Geroteerde Factor Matrix:

\begin{tabular}{llll}
\hline Item & Factor 1 & Factor 2 & Factor 3
\end{tabular}

\section{merkkeuze-involvement}

$\begin{array}{llll}1 & .75 & .31 & -.02 \\ 2 & .68 & .20 & -.01 \\ 5 & .53 & .42 & .11 \\ 6 & .70 & .23 & .27 \\ 7 & .75 & .42 & -.06 \\ 8 & .62 & .32 & .17 \\ 9 & .59 & .13 & .17 \\ 12 & .76 & .21 & -.07 \\ 17 & .76 & .14 & .22 \\ 20 & .70 & .03 & .20 \\ 23 & .65 & .36 & .05\end{array}$

$\begin{array}{llll}\text { commitment } & & & \\ 1 & .31 & .69 & -.08 \\ 2 & .53 & .66 & -.12 \\ 3 & .46 & .68 & .17 \\ 4 & .07 & .77 & .09 \\ 5 & .36 & .77 & .14 \\ 6 & .50 & .64 & .12\end{array}$

\section{deliberatie}

$1 \quad .10$

.26

.66

.07

$-.08$

.73

$3 \quad .18$

$4 \quad .04$

5

.09

$-.15$

.69

.03

.12

.76

.05

.12

.78

.83 
BIJLAGE 9.2: Jeans

\begin{tabular}{|c|c|c|c|c|}
\hline Factor & Eigenwaarde & Perc Var & Cum Perc & \\
\hline 1 & 9.62 & 41.8 & 41.8 & \\
\hline 2 & 2.86 & 12.4 & 54.3 & \\
\hline 3 & 1.79 & 7.8 & 62.0 & \\
\hline \multicolumn{5}{|c|}{ Geroteerde Factor Matrix } \\
\hline Item & Factor 1 & Factor 2 & Factor 3 & \\
\hline \multicolumn{5}{|c|}{ merkkeuze-involvement } \\
\hline 1 & .74 & .25 & .09 & \\
\hline 2 & .75 & .13 & .00 & \\
\hline 5 & .79 & .35 & .18 & \\
\hline 6 & .79 & .42 & .10 & \\
\hline 7 & .79 & .36 & .05 & \\
\hline 8 & .80 & .28 & -.00 & \\
\hline 9 & .60 & -.15 & -.15 & \\
\hline 12 & .63 & .46 & .20 & \\
\hline 17 & .77 & .38 & .21 & \\
\hline 20 & .74 & -.04 & .21 & \\
\hline 23 & .68 & .40 & .10 & \\
\hline \multicolumn{5}{|c|}{ commitment } \\
\hline 1 & .40 & .64 & -.12 & \\
\hline 2 & .39 & .63 & .30 & \\
\hline 3 & .31 & .64 & .10 & \\
\hline 4 & .02 & .79 & -.08 & \\
\hline 5 & .54 & .50 & .12 & \\
\hline 6 & .37 & .58 & .19 & \\
\hline \multicolumn{5}{|c|}{ deliberatie } \\
\hline 1 & .26 & .39 & .65 & \\
\hline 2 & .01 & .41 & .62 & \\
\hline 3 & .20 & -.00 & .64 & \\
\hline 4 & .00 & -.08 & .79 & \\
\hline 5 & -.24 & .35 & .60 & \\
\hline 6 & .13 & -.18 & .79 & \\
\hline
\end{tabular}


BLJLAGE 9.3: Frisdrank

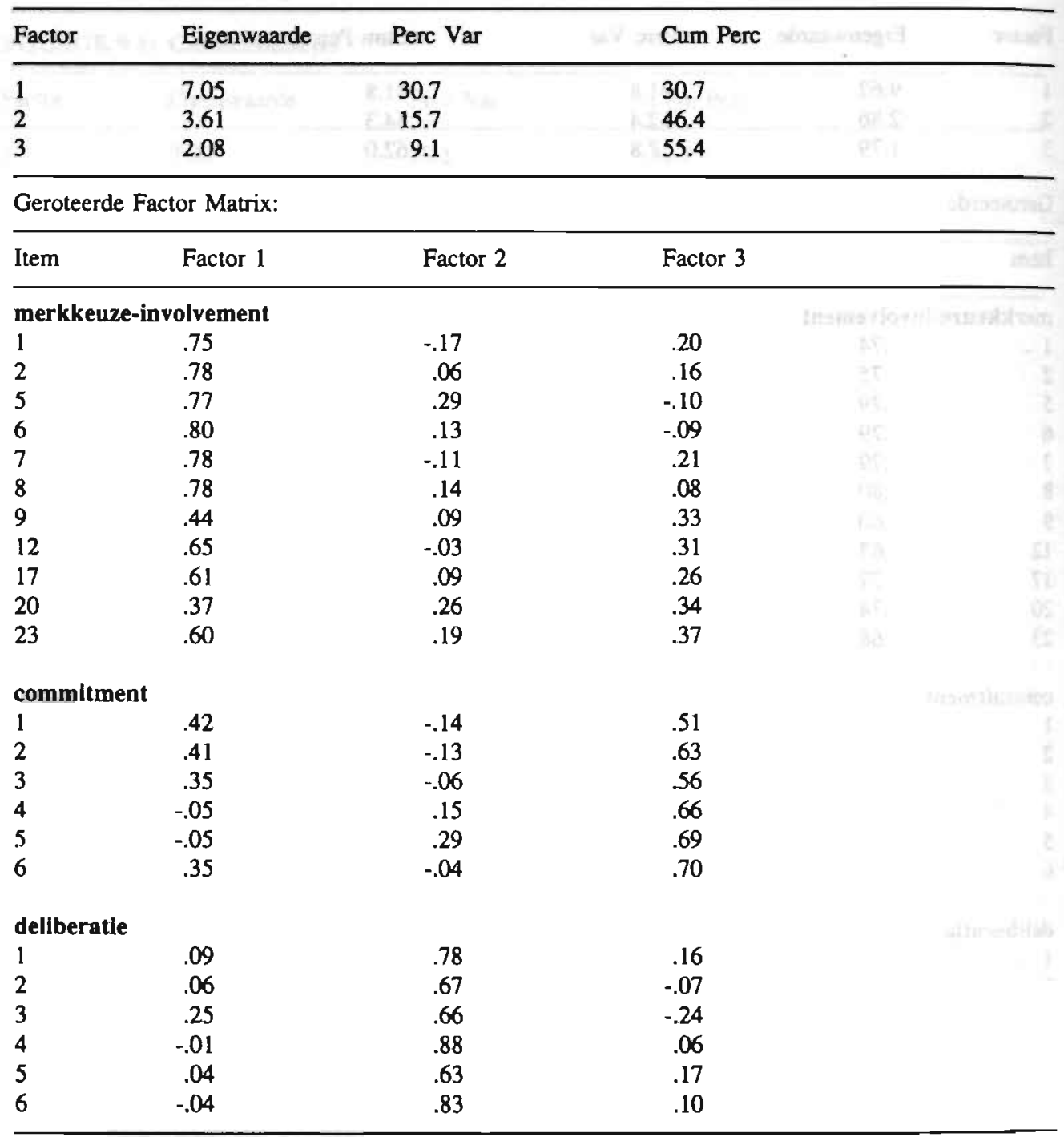




\section{Onderdeel I}

\section{ONBESPEELDE CASSETTEBANDJES}

Alle vragen in dit onderdeel hebben betrekking op onbespeelde cassettebandjes. Voor de eenvoud staat echter cassettebandje(s) vermeld. Wilt u per vraag het antwoord aankruisen dat volgens $u$ het best van toepassing is?

1. Heeft $\mathrm{u}$ in de afgelopen 6 maanden een onbespeeld cassettebandje gekocht?

\begin{tabular}{lllrr}
\hline & ja & & 589 & $70.8 \%$ \\
n & nee & (wilt u doorgaan naar onderdeel II) & 242 & $29.1 \%$ \\
b & weet niet & (wilt u doorgaan naar onderdeel II) & 1 & $0.1 \%$
\end{tabular}

2. Van welk merk was het cassettebandje dat $u$ het meest recent heeft gekocht?
口 Zie bijvoegsel. (één merk invullen) weet niet

3. Heeft u dit cassettebandje voor een speciale gelegenheid of een speciaal gebruik gekocht?
口 ja, nl. Zie bijvoegsel. (zelf invullen) nee

4. Bent $u$ in het algemeen tevreden of ontevreden over het door u gekochte cassettebandje?
a tevreden
(wilt u doorgaan naar vraag 5a van dit onderdeel) $55293.9 \%$
ontevreden
(wilt u doorgaan naar vraag 6a van dit onderdeel) 10
$1.7 \%$
weet niet/geen mening (wilt u doorgaan naar vraag 7 van dit onderdeel) $26 \quad 4.4 \%$

5a. Wilt $\mathrm{u}$ aangeven hoe tevreden $\mathrm{u}$ bent met het door $\mathrm{u}$ gekochte cassettebandje? (slechts €́n hokje aankruisen).

$\begin{array}{lllllllll}\text { enigszins } & 3 & 3 & 10 & 42 & 104 & 189 & 201 & \text { zer } \\ \text { tevreden } & \square & \square & \square & \square & \square & \square & \square & \text { tevreden } \\ & 1 & 2 & 3 & 4 & 5 & 6 & 7 & \\ & 0.5 & 0.5 & 1.8 & 7.6 & 18.8 & 34.2 & 36.4 \text { (in \%) } \\ & \text { Gemiddelde: } & 5.9 & \text { Std. } & \text { dev.: } & 1.1 & \end{array}$

5b. Voor hoeveel procent bent u tevreden met het door u gekochte cassettebandje?

Wilt u hierbij een percentage noemen op de schaal van $0 \mathrm{t} / \mathrm{m} \mathrm{100,} \mathrm{waarbij} \mathrm{geldt:} 0 \%=$ enigszins tevreden en $100 \%$ = zeer tevreden.

Ik ben voor .... procent tevreden. (Wilt u doorgaan naar vraag 7) Zie bijvoegsel

6a. Wilt $u$ aangeven hoe ontevreden $u$ bent met het door u gekochte cassettebandje? (slechts éen hokje aankruisen).

$\begin{array}{lllllllll}\text { enigszins } & 1 & 2 & 3 & 2 & 1 & - & 1 & \text { zeer } \\ \text { ontevreden } & \square & \square & \square & \square & \square & \square & \square & \text { ontevreden } \\ & 1 & 2 & 3 & 4 & 5 & 6 & 7 & \\ & 10.0 & 20.0 & 30.0 & 20.0 & 10.0 & - & 10.0 & \text { (in\%) } \\ & \text { Gemiddelde: } & 3.4 & \text { Std. } & \text { dev.: } & 1.7 & & \end{array}$


6b. Voor hoeveel procent bent u ontevreden met het door u gekochte cassettebandje?

Wilt u hierbij een percentage noemen op de schaal van $0 \mathrm{t} / \mathrm{m} 100$, waarbij geldt: $0 \%=$ enigzins ontevreden en $100 \%=$ zeer ontevreden.

Ik ben voor .... procent ontevreden. Zie bijvoegsel

7. Stel dat $\mathrm{u}$ in de toekomst weer een cassettebandje koopt, hoe groot is dan de kans dat $\mathrm{u}$ hetzelfde merk koopt als bij uw meest recente aankoop?

Wilt $u$ hierbij cen percentage noemen op de aangegeven schaal, waarbij geldt:

$0 \%$ = geen enkele kans dat ik hetzelfde merk koop;

$50 \%=$ kans dat ik hetzelfde merk koop is evengroot als de kans dat ik een ander merk koop; $100 \%$ = zeker dat ik hetzelfde merk weer koop.
$\begin{array}{llllllll}4 & 5 & 4 & 3 & 3 & 158 & 24\end{array}$
$\begin{array}{llll}38 & 80 & 93 & 176\end{array}$
$\mathbf{4} \quad \mathbf{5}$

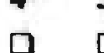
$158-24$
$\begin{array}{lllllllllll}0 \% & 10 \% & 20 \% & 30 \% & 40 \% & 50 \% & 60 \% & 70 \% & 80 \% & 90 \% & 100 \%\end{array}$
$\begin{array}{llllllllllll}0.7 & 0.9 & 0.7 & 0.5 & 0.5 & 26.9 & 4.1 & 6.5 & 13.6 & 15.8 & 29.9\end{array}$

Gemiddelde: $8.6 \quad$ Std. dev.: 2.3

8. Kunt u kort de belangrijkste reden aangeven waarom die kans zo groot is als u bij vraag 7 heeft aangegeven?

Zie bijvoegsel.

9. Consumenten kunnen steeds opnieuw een bepaald merk cassettebandje kopen, maar zij kunnen ook veranderen van merk.

Wanneer u nu uw eigen koopgedrag bij de aanschaf van cassettebandjes moet weergeven, vindt u dan dat u hoofdzakelijk steeds opnieuw hetzelfde merk koopt of dat u af en toe of voortdurend verandert van merk.

$\begin{array}{lllrr}\square & \text { steeds opnieuw hetzelfde merk } & \text { (wilt u doorgaan naar vraag 10) } & \mathbf{2 2 0} & \mathbf{3 7 . 5 \%} \\ \square & \text { af en toe veranderen van merk } & \text { (wilt u doorgaan naar vraag 10) } & \mathbf{3 1 8} & 54.3 \% \\ \square & \text { voortdurend veranderen van merk } & \text { (wilt u doorgaan naar vraag 11) } & \mathbf{4 8} & \mathbf{8 . 2 \%}\end{array}$

10. Wanneer u steeds opnieuw hetzelfde merk cassettebandje koopt of af en toe van merk verandert, kan dit verschillende redenen hebben.

10a.Bent $u$, toen u dit merk cassettebandje voor het eerst kocht, min of meer toevallig met het merk in aanraking gekomen of heeft $u$ bewust een keuze gemaakt voor het merk?

(slechts é́n hokje aankruisen).

$\begin{array}{lllllllll} & 122 & 37 & 43 & 47 & 46 & 62 & 184 & \\ \text { toeval } & \square & \square & \square & \square & \square & \square & \square & \text { bewuste keuze } \\ & 1 & 2 & 3 & 4 & 5 & 6 & 7 & \\ & 22.6 & 6.8 & 7.9 & 8.7 & 8.5 & 11.5 & 34.0 & \text { (in \%) }\end{array}$

Gemiddelde: 4.4 Std. dev.: 2.4 
10b.Koopt u het merk cassettebandje automatisch opnieuw of denkt u nog iedere keer na over uw keuze? (slechts én hokje aankruisen).

$\begin{array}{lllllllll} & 182 & 65 & 27 & 65 & 58 & 47 & 96 & \\ \text { automatisch } & \square & \square & \square & \square & \square & \square & \square & \text { denk na over keuze } \\ & 1 & 2 & 3 & 4 & 5 & 6 & 7 & \\ & 33.7 & 12.0 & 5.0 & 12.0 & 10.7 & 8.7 & 17.8 \text { (in \%) }\end{array}$

$\begin{array}{llllllll}33.7 & 12.0 & 5.0 & 12.0 & 10.7 & 8.7 & 17.8 & \text { (in \%) }\end{array}$

Gemiddelde: 3.5 Std. dev.: 2.3

10c.Vindt u het belangrijk dat u elke keer opnieuw hetzelfde merk cassettebandje koopt?

(slechts één hokje aankruisen).

$\begin{array}{llllllllll} & 266 & 125 & 42 & - & 44 & 62 & - & & \\ \text { belangrijk } & \square & \square & \square & \square & \square & \square & \square & & \text { niet belangrijk } \\ & 1 & 2 & 3 & 4 & 5 & 6 & 7 & & \\ & 49.4 & 23.2 & 7.8 & - & 8.2 & 11.5 & * & \text { (in \%) } \\ & \text { Gemiddelde: } & 2.3 & \text { Std.dev.: } & 1.8 & & \end{array}$

10d.Bent $u$ gehecht aan uw merk cassettebandje?

$\begin{array}{lllllllll} & 267 & 124 & 37 & - & 46 & 65 & - & \text { niet gehecht } \\ \text { wel gehecht } & \square & \square & \square & \square & \square & \square & \square & \\ & 1 & 2 & 3 & 4 & 5 & 6 & 7 & \end{array}$

Gemiddelde: 2.3 Std. dev.: 1.8

10 .Is het gemakkelijk of moeilijk voor $u$ om van merk cassettebandje te veranderen?

$\begin{array}{lllllllll}\text { gemakkelijk } & 179 & 62 & 50 & 78 & 49 & 46 & 73 & \\ & \square & \square & \square & \square & \square & \square & \square & \text { moeilijk } \\ & 1 & 2 & 3 & 4 & 5 & 6 & 7 & \\ & 33.3 & 11.5 & 9.3 & 14.5 & 9.1 & 8.6 & 13.6 \text { (in \%) } \\ & \text { Gemiddelde: } & 3.3 & \text { Std. } & \text { dev.: } & 2.2 & & \end{array}$

Situatie 1 en situatie 2 geven een beschrijving van twee manieren waarop u opnieuw een cassettebandje kunt kopen.

\section{Situatie 1:}

U bent indertijd min of meer toevallig met het merk van uw keuze in aanraking gekomen toen u voor het eerst dit merk cassettebandje kocht. U koopt het automatisch weer, zonder er echt over na te denken. Het is erg gemakkelijk voor $u$ om van merk te veranderen.

Situatie 2:

$\mathrm{U}$ heeft bij de eerste aankoop indertijd heel bewust voor dit merk gekozen. $U$ heeft goed over uw keuze nagedacht. Het is voor u belangrijk om steeds dit merk te kopen. Het is zeer moeilijk voor u om van merk te veranderen.

10f.Kunt $u$ aangeven in hoeverre u naar situatie 1 of naar situatie 2 neigt?

(slechts Eén hokje aankruisen).

$\begin{array}{lllllllll} & 99 & 100 & 52 & 104 & 52 & 61 & 67 & \\ \text { situatie } 1 & \square & \square & \square & \square & \square & \square & \square & \text { situatie 2 } \\ & 1 & 2 & 3 & 4 & 5 & 6 & 7 & \\ & 18.5 & 18.7 & 9.7 & 19.4 & 9.7 & 11.4 & 12.5 \text { (in \%) } \\ & \text { Gemiddelde: } & 3.7 & \text { Std. } & \text { dev.: } & 2.0 & & \end{array}$


De volgende vragen gaan over een aantal beweringen waarop $u$ kunt reageren door het aankruisen van een hokje. $U$ dient aan te geven in hoeverre $u$ het met de bewering eens of oneens bent. Bijvoorbeeld:

$\begin{array}{llllll}\square & \square & \square & \square & \square & \square \\ \begin{array}{l}\text { volledig } \\ \text { oneens }\end{array} & \begin{array}{l}\text { mee } \\ \text { oneens }\end{array} & \text { neutraal } & \text { mee eens } & \begin{array}{l}\text { volledig } \\ \text { eens }\end{array} & \begin{array}{l}\text { weet niet } \\ \text { geen mening }\end{array}\end{array}$

Bent $u$ het volledig oneens met de bewering dan kruist $u$ het meest linkse hokje aan. Als $u$ een bewering echt niet van toepassing acht, of geen mening hebt vult $u$ de kolom 'weet niet/geen mening' in. Wanneer onderstaand wordt gesproken over een merk cassettebandje, wordt bedoeld het merk van het onbespeelde cassettebandje dat $u$ hebt aangegeven bij vraag 2, dus het merk dat $u$ het laatst heeft gekocht.

11. De keuze van een bepaald merk cassettebandje is voor mij niet belangrijk.

Gemiddelde: 3.3 Std.dev.: 1.5

12. Ik vind mezelf zeer trouw ten opzichte van een bepaald merk cassettebandje.

Gemiddelde: $3.2 \quad$ Std.dev.: 1.6

13. Na de aankoop van een cassettebandje heb ik de positieve en de negatieve aspecten van mijn keuze nog eens op een rij gezet.

Gemiddelde: 2.6 Std.dev.: 1.5

14. Als ik van plan ben een bepaald merk cassettebandje te kopen, is het nogal gemakkelijk om mij van gedachten te doen veranderen en feitelijk een ander merk te kopen.

Gemiddelde: 3.4 Std.dev.: 1.6

15. Het kan me niet schelen welk merk cassettebandje ik kies.

Gemiddelde: $3.8 \quad$ Std.dev.: 1.5

16. Ik neem de keuze van een bepaald merk cassettebandje serieus.

Gemiddelde: $3.6 \quad$ Std.dev.: 1.5

17. Het is voor mij niet belangrijk dat ik me tevreden voel bij de keuze van een bepaald merk cassettebandje.

Gemiddelde: $4.0 \quad$ Std.dev.: 1.4

18. Na de aankoop van een cassettebandje heb ik het door mij gekochte merk vergeleken met andere merken.

Gemiddelde: $2.6 \quad$ Std.dev.: 1.6

$\begin{array}{lll} & \text { weet } \\ \text { volledig } & \text { volledig } & \text { niet/ } \\ \text { geen }\end{array}$

$\begin{array}{llllll}111 & 88 & 81 & 124 & 169 & 11 \\ \square & \square & \square & \square & \square & \square\end{array}$

$\begin{array}{llllll}137 & 63 & 74 & 128 & 167 & 18\end{array}$

$\begin{array}{llllll}1 & \square & \square & \square & \square & \square\end{array}$

$\begin{array}{lllll}24.1 & 11.1 & 13.0 & 22.5 & 29.3\end{array}$ $\begin{array}{llllll}118 & 69 & 65 & 118 & 199 & 18\end{array}$

$\begin{array}{llllll}20.7 & 12.1 & 11.4 & 20.7 & 35.0\end{array}$

$\begin{array}{lllll}98 & 44 & 49 & 98 & 288 \\ \square & \square & \square & \square & \square \\ 17.0 & 7.6 & 8.5 & 17.0 & 49.9\end{array}$

$\begin{array}{llllll}87 & 56 & 71 & 122 & 234 & 13\end{array}$

$\begin{array}{lllll}15.3 & 9.8 & 12.5 & 21.4 & 41.1\end{array}$

$\begin{array}{llllll}64 & 31 & 46 & 111 & 305 & 26\end{array}$

$\begin{array}{llllll}0 & \square & \square & \square & \square & \square\end{array}$

$\begin{array}{lllll}11.5 & 5.6 & 8.3 & 19.9 & 54.8\end{array}$

$\begin{array}{llllll}221 & 74 & 52 & 96 & 106 & 36\end{array}$ 
19. I $\mathrm{k}$ ben erg geïnteresseerd in het kiezen van het juiste merk cassettebandje.

Gemiddelde: $3.2 \quad$ Std.dev.: 1.6 $\begin{array}{lllll}134 & 72 & 81 & 116 & 173\end{array}$

10

$\begin{array}{lllll}23.3 & 12.5 & 14.1 & 20.1 & 30.0\end{array}$

20. Wanneer het merk cassettebandje waaraan ik de voorkeur geef niet verkrijgbaar is in de winkel, dan ga ik naar een andere winkel om het daar te kopen. Gemiddelde: 3.1 Std.dev.: 1.7

$\begin{array}{llllll}176 & 68 & 39 & 71 & 214 & 16\end{array}$

$\begin{array}{lllll}\square 1.0 & 12.0 & 6.9 & \square & \square \\ 12.5 & 37.7\end{array}$

21. Ik maak me er niet druk over welk merk cassettebandje ik kies.

Gemiddelde: 3.6 Std.dev.: 1.5

$\begin{array}{llllll}95 & 59 & 76 & 97 & 254 & 3\end{array}$

$\begin{array}{llllll}16.4 & 10.2 & 13.1 & 16.7 & 43.7\end{array}$

22. Ik voel me niet betrokken bij de merkkeuze van cassettebandjes.

Gemiddelde: $3.5 \quad$ Std.dev.: 1.5

$\begin{array}{llllll}105 & 68 & 51 & 117 & 234 & 10\end{array}$

$\begin{array}{lllll}\square & \square & \square & \square & \square \\ 18.3 & 11.8 & 8.9 & 20.3 & 40.7\end{array}$

23. Wanneer een ander merk cassettebandje in de aanbieding is, koop ik dat eerder dan mijn gebruikelijke merk.

Gemiddelde: $3.2 \quad$ Std.dev.: 1.6

$\begin{array}{llllll}147 & 84 & 62 & 90 & 194 & 7 \\ \square & \square & \square & \square & \square & \square \\ 25.5 & 14.6 & 10.7 & 15.6 & 33.6 & \end{array}$

24. Na de aankoop van een cassettebandje heb ik nog vaak nagedacht over de voor- en nadelen van de door mij gemaakte keuze.

Gemiddelde: 2.0 Std.dev.: 1.3

$\begin{array}{llllll}288 & 94 & 93 & 39 & 39 & 27 \\ \square & \square & \square & \square & \square & \square \\ 52.1 & 17.0 & 16.8 & 7.1 & 7.1 & \end{array}$

25. Wanneer het merk cassettebandje waaraan ik de voorkeur geef niet verkrijgbaar is in de winkel, dan koop ik een ander merk dat ik net zo goed vind in die winkel.

Gemiddelde: $2.9 \quad$ Std.dev.: 1.7

$\begin{array}{llllll}183 & 101 & 35 & 78 & 172 & 15\end{array}$

$\begin{array}{lllll}32.2 & 17.8 & 6.2 & 13.7 & 30.2\end{array}$

26. Van de keuze van een verkeerd merk cassettebandje heb ik spijt.

Gemiddelde: $3.7 \quad$ Std.dev.: 1.5

$\begin{array}{llllll}95 & 47 & 54 & 97 & 247 & 46\end{array}$

$\square \quad \square \quad \square \quad \square \quad \square \quad \square$

$\begin{array}{lllll}17.6 & 8.7 & 10.0 & 18.0 & 45.7\end{array}$

27. Ik kies zorgvuldig een bepaald merk cassettebandje uit.

Gemiddelde: 3.4 Std.dev.: 1.5

$\begin{array}{llllll}106 & 60 & 85 & 124 & 197 & 10\end{array}$

$\begin{array}{lllll}18.5 & 10.5 & 14.9 & 21.7 & 34.4\end{array}$

28. Na de aankoop van een cassettebandje, praat ik nog vaak over het door mij gekochte merk met familie, vrienden of bekenden.

Gemiddelde: 1.9 Std.dev.: 1.3

$\begin{array}{llllll}331 & 72 & 73 & 40 & 36 & 34 \\ \square & \square & \square & \square & \square & \square \\ 60.0 & 13.0 & 13.2 & 7.2 & 6.5 & \end{array}$

29. Na de aankoop van een cassettebandje heb ik verschillende advertenties over cassettebandjes bekeken.

Gemiddelde: $1.8 \quad$ Std.dev.: 1.2

$\begin{array}{lllll}348 & 81 & 52 & 35 & 33 \\ \square & \square & \square & \square & \square \\ 63.4 & 14.8 & 9.5 & 6.4 & 6.0\end{array}$ 
30. Het maakt voor mij een verschil welk merk cassettebandje ik kies.

Gemiddelde: 3.5 Std.dev.: 1.5

$\begin{array}{llllll}111 & 56 & 68 & 131 & 208 & 10 \\ \square & \square & \square & \square & \square & \square \\ 19.3 & 9.8 & 11.8 & 22.8 & 36.2 & \end{array}$

$\begin{array}{lllll}110 & 45 & 35 & 109 & 275\end{array}$ 10

$\begin{array}{lllll}19.2 & 7.8 & 6.1 & 19.0 & 47.9\end{array}$

32. Na de aankoop van een cassettebandje heb ik nog naar de beoordeling van cassettebandjes in bijv. de Consumentengids gekeken.

Gemiddelde: 2.1 Std.dev.: 1.5

$\begin{array}{llllll}305 & 60 & 55 & 59 & 69 & 36 \\ \square & \square & \square & \square & \square & \square \\ 55.7 & 10.9 & 10.0 & 10.8 & 12.6 & \end{array}$

33. Voor mij is de keuze van cen bepaald merk cassettebandje niet relevant.

Gemiddelde: $3.6 \quad$ Std.dev.: 1.5

$\begin{array}{lllll}100 & 58 & 68 & 107 & 232 \\ \square & \square & \square & \square & \square \\ 17.7 & 10.3 & 12.0 & 18.9 & 41.1\end{array}$

34. Aan welk merk cassettebandje geeft u de voorkeur wanneer u opnieuw een cassettebandje gaat kopen?

.Zie bijvoegsel.

(zelf invullen)

35. Neemt $u$ andere merken cassettebandjes in overweging wanneer u opnieuw een cassettebandje gaat kopen?

口 ja, ik overweeg

Zie bijvoegsel.

nee

(zelf merken invullen)

36a.Stel dat het merk waaraan u de voorkeur geeft niet verkrijgbaar is in de winkel die u bezoekt, koopt $\mathrm{u}$ dan een ander merk in die winkel?

ja, dan koop ik

Zie bijvoegsel

(zelf invullen)

nee

36b.Stel dat het merk waaraan u de voorkeur geeft fors in prijs verhoogd is, koopt u dan een ander merk?

ja, dan koop ik

Zie bijroegsel.

(zelf invullen)

36c.Stel dat sen ander merk fors in prijs verlaagd is, koopt u dan dat andere merk?

a ja, dan koop ik

Zie bijvoegsel (zelf invullen)

nee 
Graag willen we enkele algemene gegevens van $u$ vernemen.
1. Geslacht : $\square$ man
$29337.6 \%$
vrouw
$48762.4 \%$

2. Leeftijd $\quad: \ldots . .$. jaar

\section{Zie bijroegsel}

3. Beroep

Zie bijvoegsel.

4. Uit hoeveel personen bestaat uw huishouden, uzelf meegerekend? Zie bijvoegsel

personen

5. Hoe hoog is ongeveer het netto inkomen van uw huishouden per maand?

(dus alle gezinsleden die inkomen inbrengen meegerekend)

Rekent u dan alstublieft inkomsten als vakantietoeslag, tantième of $13 \mathrm{e}$ maand, kinderbijslag en huursubsidie niet mee.

$\begin{array}{rrrr}\square & \text { minder dan } f 1.000 & 34 & 4.6 \% \\ \square & f 1.000 \text { tot } f 1.500 & 57 & 7.8 \% \\ \square & f 1.500 \text { tot } f 2.000 & 73 & 9.9 \% \\ \square & f 2.000 \text { tot } f 2.500 & 116 & 15.8 \% \\ \square & f 2.500 \text { tot } f 3.000 & 115 & 15.7 \% \\ \square & f 3.000 \text { tot } f 4.000 & 169 & 23.0 \% \\ \square & f 4.000 \text { tot } f 5.000 & 97 & 13.2 \% \\ \square & f 5.000 \text { of meer } & 73 & 9.9 \%\end{array}$

\section{Gemiddelde: 5.0 Std.dev.: 1.9}

6. Naam

Adres

Plaats

Telefoon

7. Ik wil graag geïnformeerd worden over de resultaten van dit onderzoek.
a ja
630
82.2\%
口 nee
136
$17.8 \%$

8. Ik wil in de toekomst best nog eens meewerken aan het invullen van een vergelijkbare vragenlijst.

$\begin{array}{llrr}\square & \text { ja } & 724 & 93.9 \% \\ \square & \text { nee } & 47 & 6.1 \%\end{array}$

Ruimte voor opmerkingen

Hartelijk dank voor uw medewerking aan dit onderdeel. Wilt u doorgaan met onderdeel II over haarshampoo? 


\section{Onderdeel II}

\section{HAARSHAMPOO}

\section{Wilt u per vraag het antwoord aankruisen dat volgens $u$ het best van toepassing is?}

1. Heeft $\mathrm{u}$ in de afgelopen 3 maanden haarshampoo gekocht?

$\begin{array}{lllrr} & \text { ja } & 809 & 96.8 \% \\ \text { 口 } & \text { nee } & \text { (wilt u doorgaan naar de algemene gegevens bij dit onderdeel) } & 26 & 3.1 \% \\ \square & \text { weet niet } & \text { (wilt u doorgaan naar de algemene gegevens bij dit onderdeel) } & 1 & 0.1 \%\end{array}$

2. Van welk merk was de haarshampoo die u het meest recent heeft gekocht?

(Met merk wordt bedoeld Elsève, Andrelon, Schwarzkopf, Etos etc. en niet anti-roos, iederedag, zijde shampoo etc.)

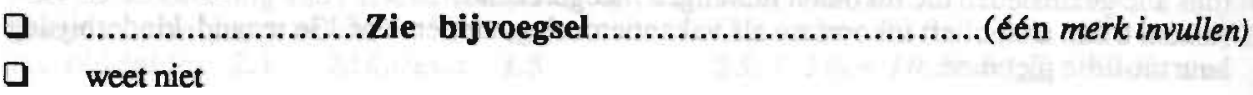

3. Heeft u deze haarshampoo voor een speciaal gebruik gekocht?
a ja, nl.
Zie bijvoegsel.
(zelf invullen)

4. Bent $\mathrm{u}$ in het algemeen tevreden of ontevreden over de door u gekochte haarshampoo?

\begin{tabular}{lllrl}
\hline & tevreden & (wilt u doorgaan naar vraag 5a van dit onderdeel) & $\mathbf{7 7 3} 95.7 \%$ \\
ontevreden & (wilt u doorgaan naar vraag 6a van dit onderdeel) & $19.4 \%$ \\
weet nie/geen mening & (wilt u doorgaan naar vraag 7 van dit onderdeel) & 16 & $2.0 \%$
\end{tabular}

5a. Wilt u aangeven hoe tevreden u bent met de door u gekochte haarshampoo? (slechts één hokje aankruisen).

enigszins

$\begin{array}{lllllll}5 & 9 & 19 & 62 & 143 & 250 & 281 \\ \square & 0 & \square & \square & \square & \square & \square \\ 1 & 2 & 3 & 4 & 5 & 6 & 7 \\ 0.7 & 1.2 & 2.5 & 8.1 & 18.6 & 32.5 & 36.5 \text { (in \%) } \\ \text { Gemiddelde: } & 5.9 & \text { Stdd.dev.: } 1.2\end{array}$

zeer tevreden tevreden

5b. Voor hoeveel procent bent u tevreden met de door u gekochte haarshampoo?

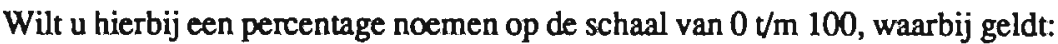
$0 \%=$ enigszins tevreden en $100 \%=$ zeer tevreden. Ik ben voor ..... procent tevreden. (Wilt u nu doorgaan naar vraag 7) Zie bijvoegsel

6a. Wilt u aangeven hoe ontevreden u bent met de door u gekochte haarshampoo? (slechts én hokje aankruisen).

enigszins

ontevreden

\begin{tabular}{llllllll}
1 & - & 2 & 4 & 5 & 2 & 5 \\
9 & $\square$ & $\square$ & $\square$ & $\square$ & $\square$ & $\square$ \\
1 & 2 & 3 & 4 & 5 & 6 & 7 \\
5.3 & - & 10.5 & 21.1 & 26.3 & 10.5 & 26.3 & (in\%) \\
Gemiddelde: & 5.0 & \multicolumn{5}{l}{ Std.dev.: } & 1.7
\end{tabular}

zeer ontevreden 
6b. Voor hoeveel procent bent u ontevreden met de door u gekochte haarshampoo? Wilt u hierbij een percentage noemen op de schaal van $0 \mathrm{t} / \mathrm{m} \mathrm{100,} \mathrm{waarbij} \mathrm{geldt:}$ $0 \%=$ enigzins ontevreden en $100 \%=$ zeer ontevreden.

Ik ben voor .... procent ontevreden. Zie bijvoegsel

7. Stel dat $\mathrm{u}$ in de toekomst weer haarshampoo koopt, hoe groot is dan de kans dat $\mathrm{u}$ hetzelfde merk koopt als bij uw meest recente aankoop?

Wilt $u$ hierbij een percentage noemen op de aangegeven schaal, waarbij geldt:

$0 \%$ = geen enkele kans dat ik hetzelfde merk koop;

$50 \%=$ kans dat ik hetzelfde merk koop is evengroot als de kans dat ik een ander merk koop; $100 \%$ = zeker dat ik hetzelfde merk weer koop.
135
$7 \quad 7$
16
16927
40
89
$123 \quad 311$
$\begin{array}{llll}0 \% & 10 \% & 20 \% & 30 \%\end{array}$
$\begin{array}{lllllll}40 \% & 50 \% & 60 \% & 70 \% & 80 \% & 90 \% & 100 \%\end{array}$
$\begin{array}{llll}1.6 & 0.6 & 0.9 & 0.9\end{array}$
$\begin{array}{llll}2.0 & 20.9 & 3.3 & 5.0\end{array}$
11.015 .238 .5 (in \%)
Gemiddelde: 8.8
Std.dev.: 2.4

8. Kunt $u$ kort de belangrijkste reden aangeven waarom die kans zo groot is als u bij vraag 7 heeft aangegeven?

Zie bij voegsel.

9. Consumenten kunnen steeds opnieuw een bepaald merk haarshampoo kopen, maar zij kunnen ook veranderen van merk.

Wanneer u nu uw eigen koopgedrag bij de aanschaf van haarshampoo moet weergeven, vindt $u$ dan dat u hoofdzakelijk steeds opnieuw hetzelfde merk koopt of dat u af en toe of voortdurend verandert van merk.

\begin{tabular}{lllrr}
\hline & steeds opnieuw hetzelfde merk & (wilt u doorgaan naar vraag 10) & 337 & $42.0 \%$ \\
\hline & af en toe veranderen van merk & (wilt u doorgaan naar vraag 10) & 406 & $50.6 \%$ \\
$\square$ & voortdurend veranderen van merk & (wilt u doorgaan naar vraag 11) & 59 & $7.4 \%$
\end{tabular}

10. Wanneer u steeds opnieuw hetzelfde merk haarshampoo koopt of af en toe van merk verandert, kan dit verschillende redenen hebben.

10a.Bent $\mathrm{u}$, toen $\mathrm{u}$ dit haarshampoo voor het eerst kocht, min of meer toevallig met het merk in aanraking gekomen of heeft $\mathrm{u}$ bewust een keuze gemaakt voor het merk?

(slechts é́n hokje aankruisen).

$\begin{array}{lllllllll} & 207 & 47 & 48 & 55 & 44 & 111 & 236 & \\ \text { toeval } & \square & \square & \square & \square & \square & \square & \square & \text { bewuste keuze } \\ & 1 & 2 & 3 & 4 & 5 & 6 & 7 & \\ & 27.7 & 6.3 & 6.4 & 7.4 & 5.9 & 14.8 & 31.6 \text { (in \%) } \\ & \text { Gemiddelde: } & 4.3 & \text { Std.dev.: } & 2.5 & & \end{array}$


10b.Koopt $\mathrm{u}$ het merk haarshampoo automatisch opnieuw of denkt u nog iedere keer na over uw keuze? (slechts én hokje aankruisen).

$\begin{array}{lllllllll} & 297 & 80 & 31 & 52 & 50 & 87 & 150 & \text { denk na over keuze } \\ \text { automatisch } & \square & \square & \square & \square & \square & \square & \square & 7 \\ & 1 & 2 & 3 & 4 & 5 & 6 & 7 & \\ & 39.8 & 10.7 & 4.1 & 7.0 & 6.7 & 11.6 & 20.1 \text { (in \%) } \\ & \text { Gemiddelde: } & 3.5 & \text { Std.dev.: } & 2.5\end{array}$

10c. Vindt $\mathrm{u}$ het belangrijk dat $\mathrm{u}$ elke keer opnieuw hetzelfde merk haarshampoo koopt?

(slechts één hokje aankruisen).

$\begin{array}{lllllllll} & 387 & 166 & 53 & - & 42 & 99 & - & \text { niet belangrijk } \\ \text { belangrijk } & \square & \square & \square & \square & \square & \square & \square & \text { (in\%) } \\ & 1 & 2 & 3 & 4 & 5 & 6 & 7 & \\ & 51.8 & 22.2 & 7.1 & - & 5.6 & 13.3 & - & \text { (in } \\ & \text { Gemiddelde: } & 2.3 & \text { Std.dev.: } 1.8 & & \end{array}$

10d.Bent $u$ gehecht aan uw merk haarshampoo?

$\begin{array}{llllllllll} & & 380 & 152 & 58 & - & 77 & 81 & - & \text { nel gehecht } \\ & \square & \square & \square & \square & \square & \square & \square & \text { niet gehecht } \\ & 1 & 2 & 3 & 4 & 5 & 6 & 7 & \text { (in\%) } \\ & 50.8 & 20.3 & 7.8 & - & 10.3 & 10.8 & - & \text { (in }) \\ & \text { Gemiddelde: } & 2.3 & \text { Std.dev.: } 1.8 & & \end{array}$

10e.Is het gemakkelijk of moeilijk voor u om van merk haarshampoo te veranderen?

$\begin{array}{lllllllll} & 199 & 82 & 77 & 90 & 61 & 84 & 152 & \\ \text { gemakkelijk } & \square & \square & \square & \square & \square & \square & \square & \text { moeilijk } \\ & 1 & 2 & 3 & 4 & 5 & 6 & 7 & \\ & 26.7 & 11.0 & 10.3 & 12.1 & 8.2 & 11.3 & 20.4 & \text { (in\%) } \\ & \text { Gemiddelde: } & 3.8 & \text { Std.dev.: } & 2.3 & & \end{array}$

Situatie 1 en situatie 2 geven een beschrijving van twee manieren waarop u opnieuw haarshampoo kunt kopen.

Situatie 1:

$\mathrm{U}$ bent indertijd min of meer toevallig met het merk van uw keuze in aanraking gekomen toen u voor het eerst dit merk haarshampoo kocht. U koopt het automatisch weer, zonder er echt over na te denken. Het is erg gemakkelijk voor $u$ om van merk te veranderen.

Situatie 2:

U heeft bij de eerste aankoop indertijd heel bewust voor dit merk gekozen. U heeft goed over uw keuze nagedacht. Het is voor u belangrijk om steeds dit merk te kopen. Het is zeer moeilijk voor $u$ om van merk te veranderen.

10f.Kunt u aangeven in hoeverre u naar situatie 1 of naar situatie 2 neigt? (slechts één hokje aankruisen).

situatic 1

\begin{tabular}{llllllll}
119 & 110 & 90 & 106 & 92 & 89 & 133 & \\
$\square$ & $\square$ & $\square$ & $\square$ & $\square$ & $\square$ & $\square$ & situatie 2 \\
1 & 2 & 3 & 4 & 5 & 6 & 7 & \\
16.1 & 14.9 & 12.2 & 14.3 & 12.4 & 12.0 & 18.0 & (in\%) \\
Gemiddelde: & 4.0 & \multicolumn{5}{c}{ Std.dev.: } & 2.1
\end{tabular}


De volgende vragen gaan over een aantal beweringen waarop $u$ kunt reageren door het aankruisen van een hokje. U dient aan te geven in hoeverre $u$ het met de bewering eens of oneens bent.

Bijvoorbeeld:

$\begin{array}{llllll}\square & \square & \square & \square & \square & \square \\ \text { volledig } & \begin{array}{l}\text { mee } \\ \text { oneens }\end{array} & \text { neutraal } & \text { mee eens } & \begin{array}{l}\text { volledig } \\ \text { cens }\end{array} & \begin{array}{l}\text { weet niet/ } \\ \text { geen mening }\end{array}\end{array}$

Bent $u$ het volledig oneens met de bewering dan kruist $u$ het meest linkse hokje aan. Als $u$ een bewering echt niet van toepassing acht, of geen mening hebt vult $u$ de kolom 'weet niet/geen mening' in. Wanneer onderstaand words gesproken over een merk haarshampoo, wordt bedoeld het merk haarshampoo dat $u$ hebt aangegeven bij vraag 2 , dus het merk dat $u$ het laatst heeft gekocht.

$\begin{array}{lll}\text { volledig } & \text { volledig } & \text { niet/ } \\ \text { oneens } & \text { eens } & \text { mening }\end{array}$
11. De keuze van cen bepaald merk haarshampoo is $\begin{array}{lllll}136 & 100 & 98 & 158 & 301 \\ \square & \square & \square & \square & \square\end{array}$ voor mij niet belangrijk. Gemiddelde: 3.5 Std.dev.: 1.5 $\begin{array}{lll}17.2 & 12.612 .419 .9 \quad 38.0\end{array}$

12. Ik vind mezelf zeer trouw ten opzichte van een bepaald merk haarshampoo.

Gemiddelde: 3.5 Std.dev.: 1.6

$\begin{array}{llllll}152 & 77 & 101 & 143 & 319 & 11 \\ \square & \square & \square & \square & \square & \square \\ 19.2 & 9.7 & 12.8 & 18.1 & 40.3 & \end{array}$

13. Na de aankoop van haarshampoo heb ik de positieve en de negatieve aspecten van mijn keuze nog eens op een rij gezet.
Gemiddelde: 2.9
Std.dev.: 1.5

\begin{tabular}{lllll|}
205 & 91 & 129 & 121 & 171 \\
$\square$ & $\square$ & $\square$ & $\square$ & $\square$ \\
28.6 & 12.718 .0 & 16.9 & 23.8
\end{tabular}

14. Als ik van plan ben een bepaald merk haarshampoo te kopen, is het nogal gemakkelijk om mij van gedachten te doen veranderen en feitelijk een ander merk te kopen.

Gemiddelde: 3.5 Std.dev.: 1.5

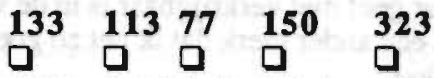

$\begin{array}{llll}16.7 & 14.29 .7 & 18.8 & 40.6\end{array}$

15. Het kan me niet schelen welk merk haarshampoo ik kies.

Gemiddelde: 4.0 Std.dev.: 1.4

$\begin{array}{llllll}85 & 69 & 57 & 140 & 444 & 8 \\ \square & \square & \square & \square & \square & \square \\ 10.7 & 8.7 & 7.2 & 17.6 & 55.8 & \end{array}$

16. Ik neem de keuze van een bepaald merk haarshampoo serieus.

Gemiddelde: $3.8 \quad$ Std.dev.: 1.4

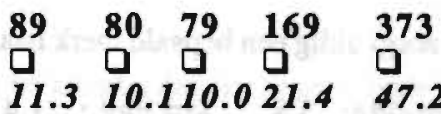

10

17. Het is voor mij niet belangrijk dat ik me tevreden 66 voel bij de keuze van een bepaald merk haarshampoo.

Gemiddelde: 4.3 Std.dev.: 1.2

$\begin{array}{lllll}8.4 & 3.2 & 5.3 & 15.2 & 67.9\end{array}$

18. Na de aankoop van haarshampoo heb ik het door mij gekochte merk vergeleken met andere merken.

Gemiddelde: $3.1 \quad$ Std.dev.: 1.6

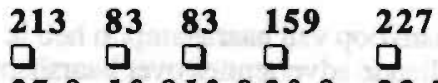


19. Ik ben erg geïnteresseerd in het kiezen van het

$\begin{array}{llll}117 & 76 & 124 & 161\end{array}$ juiste merk haarshampoo. Gemiddelde: 3.6 Std.dev.: 1.5

$\begin{array}{lllll}\square & \square & \square & \square & \square \\ 14.9 & 15.8 & 20.6 & 39.0\end{array}$

20. Wanneer het merk haarshampoo waaraan ik de voorkeur geef niet verkrijgbaar is in de winkel, dan Gemiddelde: 3.4 Std.dev.: 1.7

$\begin{array}{lllll}214 & 76 & 43 & 102 & 51\end{array}$

$\begin{array}{lllll}27.2 & 9.7 & 5.5 & 13.0 & 44.7\end{array}$

21. Ik maak me er niet druk over welk merk haarshampoo ik kies.

Gemiddelde: 3.8 Std.dev.: 1.5

$\begin{array}{llllll}102 & 77 & 75 & 134 & 407 & 7\end{array}$

$\begin{array}{lllllll}1 & \square & \square & \square & \square & \square\end{array}$

22. Ik voel me niet betrokken bij de merkkeuze van haarshampoo.

Gemiddelde: 3.8 Std.dev.: 1.5

$\begin{array}{lllll}12.8 & 9.7 & 9.4 & 16.9 & 51.2\end{array}$

$\begin{array}{llllll}102 & 82 & 78 & 143 & 381 & 16\end{array}$

$\begin{array}{llllll}1 & \square & \square & \square & \square & \square\end{array}$

23. Wanneer een ander merk haarshampoo in de aanbieding is, koop ik dat eerder dan mijn gebruikelijke merk.

Gemiddelde: $3.7 \quad$ Std.dev.: 1.5

$\begin{array}{llll}13.0 & 10.49 .9 & 18.2 & 48.5\end{array}$

$\begin{array}{llllll}123 & 100 & 73 & 109 & 381 & 14\end{array}$

$\begin{array}{llll}15.6 & 12.79 .3 & 13.9 & 48.5\end{array}$

24. Na de aankoop van haarshampoo heb ik nog vaak nagedacht over de voor-en nadelen van de door mij gemaakte keuze.

Gemiddelde: $2.4 \quad$ Std.dev.: 1.4

$\begin{array}{lllll}300 & 129 & 138 & 103 & 89\end{array}$

45

$\begin{array}{lllll}\square & \square & \square & \square & \square \\ 39.5 & 17.018 .2 & 13.6 & 11.7\end{array}$

25. Wanneer het merk haarshampoo waaraan ik de voorkeur geef niet verkrijgbaar is in de winkel, dan koop ik een ander merk dat ik net zo goed vind in die winkel.

Gemiddelde: $3.3 \quad$ Std.dev.: 1.7

$\begin{array}{llllll}202 & 123 & 55 & 75 & 334 & 17\end{array}$

$\begin{array}{llllll} & \square & \square & \square & \square & \square\end{array}$

$\begin{array}{llll}25.6 & 15.67 .0 & 9.5 & 42.3\end{array}$

26. Van de keuze van een verkeerd merk haarshampoo heb ik spijt.

Gemiddelde: 4.0 Std.dev.: 1.4

$\begin{array}{llllll}85 & 47 & 62 & 148 & 414 & 46\end{array}$

$\begin{array}{lllll}\square & \square & \square & \square & \square \\ 11.2 & 6.2 & 8.2 & 19.6 & 54.8\end{array}$

27. Ik kies zorgvuldig een bepaald merk haarshampoo uit.

Gemiddelde: $3.8 \quad$ Std.dev.: 1.4

$\begin{array}{llllll}105 & 77 & 87 & 167 & 360 & 9\end{array}$

$\begin{array}{lllll}13.2 & 9.7 & 10.9 & 21.0 & 45.2\end{array}$

28. Na de aankoop van haarshampoo, praat ik nog vaak over het door mij gekochte merk met familie, vrienden of bekenden.

Gemiddelde: 1.8 Std.dev.: 1.2

$\begin{array}{llllll}460 & 93 & 121 & 41 & 41 & 50\end{array}$

$\begin{array}{lllll}90.8 & 12.3 & 16.0 & 5.4 & 5.4\end{array}$

29. Na de aankoop van haarshampoo heb ik verschillende advertenties over haarshampoo bekeken.

Gemiddelde: 1.9 Std.dev.: 1.3

$\begin{array}{llll}464 & 11177 \quad 63\end{array}$

30. Het maakt voor mij een verschil welk merk haarshampoo ik kies.

Gemiddelde: 3.7 Std.dev.: 1.5

$\begin{array}{llllll}108 & 87 & 73 & 162 & 365 & 8\end{array}$

$\begin{array}{lllll}\square & \square & \square & \square & \square \\ 13.6 & 10.99 .2 & 20.4 & 45.9\end{array}$ 
31. Wanneer het merk haarshampoo waaraan ik de voorkeur geef niet verkrijgbaar is in de winkel, dan koop ik een willekeurig ander merk dat wel verkrijgbaar is in die winkel.

Gemiddelde: 3.9 Std.dev.: 1.5

volledig

woet

niet/

oneens

volledig geen

eens mening

$\begin{array}{llllll}111 & 64 & 59 & 110 & 441 & 17\end{array}$

$\square \quad \square \quad \square \quad \square \quad \square$

$\begin{array}{lllll}14.1 & 8.2 & 7.5 & 14.0 & 56.2\end{array}$

32. Na de aankoop van haarshampoo heb ik nog naar de beoordeling van haarshampoo in bijv. de Consumentengids gekeken.

Gemiddelde: 1.8 Std.dev.: 1.2

$\begin{array}{llllll}496 & 101 & 54 & 53 & 51 & 46\end{array}$

$\begin{array}{llll}65.7 & 13.47 .2 & 7.0 & 6.8\end{array}$

33. Voor mij is de keuze van een bepaald merk haarshampoo niet relevant.

Gemiddelde: 3.8 Std.dev.: 1.5

$\begin{array}{llllll}111 & 74 & 75 & 149 & 363 & 28\end{array}$

$\begin{array}{lllll}\square & \square & \square & \square & \square \\ 14.4 & 9.6 & 9.7 & 19.3 & 47.0\end{array}$

34. Aan welk merk haarshampoo geeft u de voorkeur wanneer u opnieuw een haarshampoo gaat kopen?

Zie bijvoegsel.

(zelfinvullen)

35. Neemt $u$ andere merken haarshampoo in overweging wanneer u opnieuw een haarshampoo gaat kopen?

a ja, ik overweeg

................. Zie bijvoegsel.

(zelf merken invullen)

36a.Stel dat het merk waaraan u de voorkeur geeft niet verkrijgbaar is in de winkel die u bezoekt, koopt $\mathrm{u}$ dan een ander merk in die winkel?

b ja, dan koop ik

$\square$ nee

Zie bijvoegsel.

(zelf invullen)

36b.Stel dat het merk waaraan u de voorkeur geeft fors in prijs verhoogd is, koopt u dan een ander merk?

- ja, dan koop ik

...................Zie bijvoegsel

(zelf invullen)

nee

36 . Stel dat een ander merk fors in prijs verlaagd is, koopt u dan dat andere merk?

ja, dan koop ik

Zie bijvoegsel.

(zelf invullen)

nee 


\section{ALGEMENE GEGEVENS}

Graag willen we enkele algemene gegevens van $u$ vernemen.

1. Geslacht : $\square$ man $16220.4 \% \quad \square$ vrouw $63479.6 \%$

2. Leeftijd :........ jaar Zie bijvoegsel

3. Beroep :....................Zie bijvoegsel

4. Uit hoeveel personen bestaat uw huishouden, uzelf meegerekend? Zie bijvoegsel

5. Hoe hoog is ongeveer het netto inkomen van uw huishouden per maand?

(dus alle gezinsleden die inkomen inbrengen meegerekend)

Rekent u dan alstublieft inkomsten als vakantietoeslag, tantieme of $13 \mathrm{e}$ maand, kinderbijslag en huursubsidie niet mee.

\begin{tabular}{rlrr}
$\square$ & minder dan $f 1.000$ & $\mathbf{3 2}$ & $\mathbf{4 . 2 \%}$ \\
\hline & $f 1.000$ tot $f 1.500$ & $\mathbf{5 8}$ & $\mathbf{7 . 7 \%}$ \\
\hline & $f 1.500$ tot $f 2.000$ & $\mathbf{7 3}$ & $9.7 \%$ \\
\hline & $f 2.000$ tot $f 2.500$ & $\mathbf{1 2 2}$ & $\mathbf{1 6 . 2 \%}$ \\
\hline & $f 2.500$ tot $f 3.000$ & $\mathbf{1 2 5}$ & $\mathbf{1 6 . 6 \%}$ \\
\hline & $f 3.000$ tot $f 4.000$ & $\mathbf{1 6 7}$ & $\mathbf{2 2 . 1} \%$ \\
$\square$ & $f 4.000$ tot $f 5.000$ & $\mathbf{1 0 0}$ & $\mathbf{1 3 . 3 \%}$ \\
\hline & $f 5.000$ of meer & $\mathbf{7 7}$ & $\mathbf{1 0 . 2 \%}$
\end{tabular}

Gemiddelde: 5.0 Std.dev.: 1.9

6. Naam

Adres

Plaats

Telefoon

7. Ik wil graag geïnformeerd worden over de resultaten van dit onderzoek.

$\begin{array}{llll}\square & \text { ja } & 643 & 82 \% \\ \text { nee } & 141 & 18 \%\end{array}$

8. Ik wil in de toekomst best nog eens meewerken aan het invullen van een vergelijkbare vragenlijst.
口 ja
745
$94.4 \%$
口 nee
$44 \quad 5.6 \%$

Ruimte voor opmerkingen 
Bijvoegsel Cassettebandjes

Vraag 2 Van welk merk was het cassettebandje dat $u$ het meest recent heeft gekocht?

$\begin{array}{lcc}\text { Merk } & \text { Frequentic } & \text { Percentage } \\ & & \\ \text { TDK } & 331 & 56.2 \% \\ \text { Maxell } & 80 & 13.6 \% \\ \text { Sony } & 75 & 12.7 \% \\ \text { Philips } & 26 & 4.4 \% \\ \text { BASF } & 22 & 3.7 \% \\ \text { Hema } & 17 & 2.9 \% \\ \text { That's } & 10 & 1.7 \% \\ \text { Anders } & 16 & 2.7 \% \\ \text { Weet niet } & 12 & 2.0 \%\end{array}$

Vraag 3 Heeft u dit cassettebandje voor een speciale gelegenheid of een speciaal gebruik gekocht?

Merk Frequentic Percentage

$\begin{array}{lrr}\text { Nee } & 250 & 42.5 \% \\ \text { Opnemen } & 234 & 39.8 \% \\ \text { Cadeau } & 33 & 5.6 \% \\ \text { Gebeurtenis } & 22 & 3.7 \% \\ \text { Gebruik in auto } & 18 & 3.1 \% \\ \text { Studie } & 9 & 1.5 \% \\ \text { Walkman } & 6 & 1.0 \% \\ \text { - } & 1 & 0.2 \% \\ \text { Anders } & 15 & 2.6 \%\end{array}$

Vraag 5b Voor hoeveel \% bent u tevreden met het door u gekochte cassettebandje?

\% Tevreden Frequentic Percentage

$\begin{array}{lrl}40 \% & 4 & 0.7 \% \\ 45 \% & 1 & 0.2 \% \\ 50 \% & 13 & 2.4 \% \\ 55 \% & 1 & 0.2 \% \\ 60 \% & 18 & 3.3 \% \\ 65 \% & 7 & 1.3 \% \\ 70 \% & 53 & 9.7 \%\end{array}$




$\begin{array}{lrr}\text { \% Tevreden } & \text { Frequentie } & \text { Percentage } \\ 71 \% & 1 & 0.2 \% \\ 75 \% & 35 & 6.4 \% \\ 80 \% & 101 & 18.5 \% \\ 83 \% & 1 & 0.2 \% \\ 85 \% & 30 & 5.5 \% \\ 86 \% & 2 & 0.4 \% \\ 90 \% & 77 & 14.1 \% \\ 92 \% & 1 & 0.2 \% \\ 95 \% & 11 & 2.0 \% \\ 98 \% & 1 & 0.2 \% \\ 99 \% & 5 & 0.9 \% \\ 100 \% & 184 & 33.7 \% \\ \text { Gemiddelde: } & 85.7 & \\ \text { Std. dev.: } & 13.8 & \end{array}$

Vraag 6b Voor hoeveel \% bent u ontevreden met het door u gekochte cassettebandje? \% Tevreden Frequentie Percentage

$\begin{array}{lll}5 \% & 1 & 10 \% \\ 40 \% & 2 & 20 \% \\ 50 \% & 4 & 40 \% \\ 60 \% & 1 & 10 \% \\ 75 \% & 1 & 10 \% \\ 100 \% & 1 & 10 \%\end{array}$

Gemiddelde: $\quad 52.0$

Std. dev.: $\quad 24.5$

Vraag 8 Kunt u kort de belangrijkste reden aangeven waarom die kans zo groot is als u bij vraag 7 heeft aangegeven.

$\begin{array}{lll}\text { Reden } & \text { Frequentie } & \text { Percentage } \\ \text { Kwaliteit } & 162 & 28.0 \% \\ \text { Tevredenheid } & 111 & 19.2 \% \\ \text { Prijs } & 75 & 13.0 \% \\ \text { Prijs/ Kwaliteit } & 67 & 11.6 \% \\ \text { Trouw/Herhalingsaankopen } & 43 & 7.4 \% \\ \text { Merk } & 28 & 4.8 \% \\ \text { Indifferent } & 27 & 4.7 \% \\ \text { Overig } & 23 & 4.0 \% \\ \text { Verkrijgbaarheid } & 15 & 2.6 \% \\ \text { Switchen } & 15 & 2.6 \% \\ \text { Product } & 12 & 2.1 \%\end{array}$


Vraag 34 Aan welk merk cassettebandje geeft u de voorkeur wanneer u opnieuw een cassettebandje gaat kopen?

$\begin{array}{lrr}\text { Merk } & \text { Frequentic } & \text { Percentage } \\ \text { TDK } & 304 & 53.1 \% \\ \text { Sony } & 66 & 11.5 \% \\ \text { Maxell } & 65 & 11.3 \% \\ \text { Philips } & 31 & 5.4 \% \\ \text { BASF } & 16 & 2.8 \% \\ \text { Hema } & 9 & 1.6 \% \\ \text { That's } & 7 & 1.2 \% \\ \text { - } & 1 & 0.2 \% \\ \text { Anders } & 17 & 3.0 \% \\ \text { Weet niet } & 57 & 9.9 \%\end{array}$

Vraag 35 Neemt $u$ andere merken cassettebandjes in overweging wanneer u opnieuw een cassettebandje gaat kopen?

Merk Frequentie Percentage

$\begin{array}{lrr}\text { Nee } & 292 & 50 \% \\ \text { TDK } & 60 & 10.3 \% \\ \text { Ja, maar geen ander } & & \\ \text { merk genoemd } & 63 & 10.7 \% \\ \text { Sony } & 51 & 8.7 \% \\ \text { Maxell } & 30 & 5.1 \% \\ \text { Philips } & 23 & 3.9 \% \\ \text { BASF } & 22 & 3.8 \% \\ \text { That's } & 5 & 0.9 \% \\ \text { Hema } & 1 & 0.2 \% \\ \text { Anders } & 8 & 1.4 \% \\ \text { Weet niet } & 29 & 5.0 \%\end{array}$


Vraag 36a Stel dat het merk waaraan u de voorkeur geeft niet verkrijgbaar is in de winkel die $u$ bezoekt, koopt $u$ dan een ander merk in die winkel?

Merk/Reden

Nee

$\mathrm{Ja}$, maar geen ander

merk genoemd

Sony

TDK

Philips

Maxell

BASF

Anders

Weet niet
Frequentie Percentage

296

$51.1 \%$

$73 \quad 12.5 \%$

$44 \quad 7.6 \%$

$37 \quad 6.4 \%$

$25 \quad 4.3 \%$

$24 \quad 4.1 \%$

$20 \quad 3.5 \%$

$9 \quad 1.6 \%$

$51 \quad 8.8 \%$

Vraag 36b Stel dat het merk waaraan u de voorkeur geeft fors in prijs verhoogd is, koopt $u$ dan een ander merk?

Merk/Reden Frequentie Percentage

Nee $\quad 189 \quad 32.7 \%$

$\mathrm{Ja}$, maar geen ander

merk genoemd

121

TDK

52

$20.9 \%$

Sony

49

$9.0 \%$

Maxell

27

$8.5 \%$

Philips

24

$4.7 \%$

Basf

21

$4.2 \%$

That's

6

$3.6 \%$

Hema

6

$1.0 \%$

Anders

11

$1.0 \%$

Weet niet

72

$1.9 \%$

$12.5 \%$

Vraag 36c Stel dat een ander merk fors in prijs verlaagd is, koopt u dan dat andere merk?

Reden/Merk Frequentie Percentage

Nee $\quad 273 \quad 47.3 \%$

Ja, maar geen merk

genoemd

Sony 


$\begin{array}{lcc}\text { Merk/ Reden } & \text { Frequentie } & \text { Percentage } \\ \text { TDK } & 28 & 4.9 \% \\ \text { Maxell } & 17 & 2.9 \% \\ \text { Philips } & 12 & 2.1 \% \\ \text { Basf } & 10 & 1.7 \% \\ \text { That's } & 4 & 0.7 \% \\ \text { Hema } & 3 & 0.5 \% \\ \text { Anders } & 10 & 1.7 \% \\ \text { Weet niet } & 69 & 12.0 \%\end{array}$

\section{Involvement}

Waarden (min. score 11; max. score 55) Frequentie Percentage

$\begin{array}{rrr}11-19 & 41 & 8.7 \% \\ 20-28 & 58 & 12.7 \% \\ 29-37 & 76 & 16.3 \% \\ 38-46 & 116 & 25.1 \% \\ 47-55 & 172 & 37.2 \%\end{array}$

Gemiddelde: $\quad 39.7$

Std.dev.: $\quad 12.4$

\section{Commitment}

Waarden (min. score 6; max. score 30) Frequentie Percentage

6-10

11-15

$16-20$

21-25

26-30

Gemiddelde: $\quad 19.8$

Std.dev.: $\quad 7.8$

\section{Deliberatie}

Waarden (min. score 6; max. score 30)

6-10

11-15

16-20

21-25

26-30
87

88

75

113

159
$16.6 \%$

$16.7 \%$

$14.5 \%$

$21.6 \%$

$30.4 \%$

Gemiddelde: $\quad 12.9$

Std.dev.: $\quad 5.8$

Frequentie Percentage

197

113

$42.8 \%$

$24.5 \%$

$20.5 \%$

$\begin{array}{ll}46 & 10.0 \% \\ 11 & 2.5 \%\end{array}$ 


\section{Vraag 2 Leeftijd}

$\begin{array}{lrcc}\text { Leeftijd } & \text { Frequentie } & \text { Percentage } & \text { AGB 1991 } \\ 0-9 & 1 & 0.1 \% & 12.2 \% \\ 10-19 & 21 & 2.7 \% & 13.0 \% \\ 20-29 & 214 & 27.5 \% & 17.1 \% \\ 30-39 & 207 & 26.7 \% & 15.9 \% \\ 40-49 & 159 & 20.4 \% & 14.2 \% \\ 50-59 & 105 & 13.6 \% & 10.2 \% \\ 60-69 & 58 & 7.5 \% & 8.7 \% \\ 70-79 & 12 & 1.5 \% & 5.8 \% \\ 80+ & 2 & 0.2 \% & 3.0 \% \\ \text { Gemiddelde: } 38.7 & \text { Std.dev.: } 13.8 & \end{array}$

\section{Vraag 3 Beroepen}

$\begin{array}{lccr}\text { Beroepen } & \text { Frequentie } & \text { Percentage } & \text { AGB 19 } \\ \text { Bedrijfshoofden en Vrije Beroepen } & 19 & 2.5 \% & 8.3 \% \\ \text { Hogere Employees } & 90 & 11.9 \% & 5.1 \% \\ \text { Middelbare Employees } & 182 & 24.1 \% & 18.2 \% \\ \text { Lagere Employees } & 79 & 10.5 \% & 9.0 \% \\ \text { Geschoolde Arbeiders } & 23 & 3.0 \% & 11.3 \% \\ \text { Ongeschoolde Arbeiders } & 21 & 2.8 \% & 7.0 \% \\ \text { Werkloos } & 12 & 1.6 \% & 6.3 \% \\ \text { Arbeidsongeschikt/WAO } & 17 & 2.3 \% & 4.9 \% \\ \text { Gepensioneerd/ Vut } & 45 & 6.0 \% & 23.4 \% \\ \text { Studerend } & 81 & 10.7 \% & 4.7 \% \\ \text { Huisvrouw/ Zonder werk } & 186 & 24.6 \% & 1.6 \%\end{array}$

Vraag 4 Uit hoeveel personen bestaat uw huishouden, uzelf meegerekend?

Personen Huishouden Frequentie Percentage AGB 1991

$\begin{array}{rrrr}1 & 157 & 20.6 \% & 30 \% \\ 2 & 254 & 33.4 \% & 32 \% \\ 3 & 131 & 17.2 \% & 15 \% \\ 4 & 160 & 21.0 \% & 17 \% \\ 5 & 52 & 6.8 \% & 5 \% \\ 6 & 7 & 0.9 \% & 1 \%\end{array}$

Gemiddelde: $2.6 \quad$ Std.dev.: 1.3 
Vraag 2 Van welk merk was de haarshampoo dat u het meest recent heeft gekocht?

Merk

Andrelon

Palmolive

Elseve

Schwarzkopf

Head en Shoulders

Thimotei

Kruitvat

Vidal Sassoon

Anders

weet niet
Frequentie

154

62

62

54

46

39

37

34

315

1
Percentage

$19.2 \%$

$7.7 \%$

$7.7 \%$

$6.7 \%$

$5.7 \%$

$4.9 \%$

$4.6 \%$

$4.2 \%$

$39.2 \%$

$0.1 \%$

Vraag 3 Heeft u de haarshampoo voor een speciale gelegenheid of een speciaal gebruik gekocht?

Gelegenheid

Nee

Volume/ Anti- roos

Voor wassen

Allergie

Kindershampoo

Haaruitval

Onder de douche

Anders
Frequentie

368

245

145

5

5

3

2

29
Percentage

$45.9 \%$

$30.5 \%$

$18.1 \%$

$0.6 \%$

$0.6 \%$

$0.4 \%$

$0.2 \%$

$3.6 \%$

Vraag 5b Voor hoeveel \% bent u tevreden met de door u gekochte haarshampoo?

\% Frequentie Percentage

$\begin{array}{lll}0 & 1 & 0.1 \% \\ 10 & 1 & 0.1 \% \\ 11 & 1 & 0.1 \% \\ 25 & 1 & 0.1 \% \\ 30 & 3 & 0.4 \% \\ 38 & 1 & 0.1 \% \\ 40 & 5 & 0.7 \%\end{array}$




$\begin{array}{lrr}45 & 4 & 0.5 \% \\ 50 & 23 & 3.0 \% \\ 55 & 4 & 0.5 \% \\ 60 & 32 & 4.2 \% \\ 65 & 6 & 0.8 \% \\ 70 & 71 & 9.3 \% \\ 72 & 1 & 0.1 \% \\ 75 & 58 & 7.6 \% \\ 80 & 146 & 19.1 \% \\ 85 & 28 & 3.7 \% \\ 86 & 1 & 0.1 \% \\ 89 & 1 & 0.1 \% \\ 90 & 94 & 12.3 \% \\ 95 & 22 & 2.9 \% \\ 98 & 1 & 0.1 \% \\ 99 & 12 & 1.6 \% \\ 100 & 249 & 32.5 \% \\ \text { Gemiddelde: } & 84.3 \\ \text { Std.dev.: } & 15.9\end{array}$

Vraag 6b Voor hoeveel \% bent u ontevreden met de door u gekochte haarshampoo?

\% Frequentic Percentage

$\begin{array}{llr}40 & 2 & 10.5 \% \\ 50 & 3 & 15.8 \% \\ 60 & 4 & 21.1 \% \\ 65 & 1 & 5.3 \% \\ 70 & 1 & 5.3 \% \\ 75 & 1 & 5.3 \% \\ 90 & 2 & 10.5 \% \\ 95 & 1 & 5.3 \% \\ 99 & 1 & 5.3 \% \\ 100 & 3 & 15.8 \% \\ \text { Gemiddelde: } & 71.3 \\ \text { Std.dev.: } & 21.6\end{array}$


Vraag 8 Kunt u kort de belangrijkste reden aangeven waarom die kans zo groot is als u bij vraag 7 heeft aangegeven.

$\begin{array}{lcr}\text { Reden } & \text { Frequentie } & \text { Percentage } \\ & & \\ \text { Tevredenheid } & 318 & 40.1 \% \\ \text { Prijs/ Kwaliteit } & 102 & 12.9 \% \\ \text { Prijs } & 75 & 9.5 \% \\ \text { Trouw/ } & & \\ \text { Herhalingsaankopen } & 62 & 7.8 \% \\ \text { Product } & 55 & 6.9 \% \\ \text { Kwaliteit } & 49 & 6.2 \% \\ \text { Switchen } & 44 & 5.5 \% \\ \text { Indifferent } & 24 & 3.0 \% \\ \text { Verkrijgbaarheid } & 18 & 2.3 \% \\ \text { Merk } & 11 & 1.4 \% \\ \text { Overig } & 35 & 4.4 \%\end{array}$

Vraag 34 Aan welk merk haarshampoo geeft u de voorkeur wanneer u opnieuw haarshampoo gaat kopen?

Merk Frequentie Percentage

$\begin{array}{lrr}\text { Andrelon } & 127 & 16.3 \% \\ \text { Elseve } & 64 & 8.2 \% \\ \text { Palmolive } & 54 & 6.9 \% \\ \text { Schwarzkopf } & 41 & 5.2 \% \\ \text { Head en Shoulders } & 41 & 5.2 \% \\ \text { Thimotei } & 28 & 3.6 \% \\ \text { Vidal Sassoon } & 28 & 3.6 \% \\ \text { Kruitvat } & 27 & 3.5 \% \\ \text { Anders } & 297 & 38.0 \% \\ \text { weet niet } & 74 & 9.5 \%\end{array}$


Vraag 35 Neemt $u$ andere merken haarshampoo in overweging wanneer $u$ opnieuw haarshampoo gaat kopen?

$\begin{array}{lcr}\text { Redenen/merken } & \text { Frequentie } & \text { Percent } \\ \text { Nee } & 481 & 59.8 \% \\ \text { Ja, maar geen ander } & & \\ \text { merk genoemd } & 56 & 7.0 \% \\ \text { Andrelon } & 43 & 5.3 \% \\ \text { Elseve } & 36 & 4.5 \% \\ \text { Schwarzkopf } & 11 & 1.4 \% \\ \text { Palmolive } & 9 & 1.1 \% \\ \text { Thimotei } & 9 & 1.1 \% \\ \text { Vidal Sassoon } & 8 & 1.0 \% \\ \text { Kruitvat } & 8 & 1.0 \% \\ \text { Head en Shoulders } & 7 & 0.9 \% \\ \text { Anders } & 92 & 11.4 \% \\ \text { weet niet } & 45 & 5.6 \%\end{array}$

Vraag 36a Stel dat het merk waaraan u de voorkeur geeft niet verkrijgbaar is in de winkel die $u$ bezoekt, koopt $u$ dan een ander merk in die winkel?

Redenen/merken Frequentie Percentage

$\begin{array}{lrr}\text { Nee } & 486 & 60.5 \% \\ \text { Ja, maar geen ander } & & \\ \text { merk genoemd } & 99 & 11.3 \% \\ \text { Andrelon } & 37 & 4.6 \% \\ \text { Elseve } & 22 & 2.7 \% \\ \text { Schwarzkopf } & 10 & 1.2 \% \\ \text { Thimotei } & 8 & 1.0 \% \\ \text { Palmolive } & 7 & 0.9 \% \\ \text { Head en Shoulders } & 5 & 0.6 \% \\ \text { Kruitvat } & 5 & 0.6 \% \\ \text { Vidal Sassoon } & 4 & 0.5 \% \\ \text { Anders } & 53 & 6.6 \% \\ \text { weet niet } & 74 & 9.2 \%\end{array}$


Vraag 36b Stel dat het merk waaraan u de voorkeur geeft, fors in prijs verhoogd is, koopt $u$ dan een ander merk?

$\begin{array}{lrr}\text { Redenen/merken } & \text { Frequentie } & \text { Percentage } \\ \text { Nee } & 359 & 44.7 \% \\ \text { Ja, maar geen ander } & & \\ \text { merk genoemd } & 143 & 17.7 \% \\ \text { Andrelon } & 43 & 5.4 \% \\ \text { Elseve } & 18 & 2.2 \% \\ \text { Schwarzkopf } & 13 & 1.6 \% \\ \text { Kruitvat } & 13 & 1.6 \% \\ \text { Palmolive } & 11 & 1.4 \% \\ \text { Thimotei } & 5 & 0.6 \% \\ \text { Vidal Sassoon } & 4 & 0.5 \% \\ \text { Head en Shoulders } & 2 & 0.2 \% \\ \text { Anders } & 70 & 8.7 \% \\ \text { weet niet } & 122 & 15.2 \%\end{array}$

Vraag 36c Stel dat een ander merk fors in prijs verlaagd is, koopt u dan dat andere merk?

$\begin{array}{lrr}\text { Redenen/merken } & \text { Frequentie } & \text { Percent } \\ \text { Nee } & 519 & 64.6 \% \\ \text { Ja, maar geen ander } & & \\ \text { merk genoemd } & 113 & 14.1 \% \\ \text { Andrelon } & 18 & 2.2 \% \\ \text { Elseve } & 11 & 1.4 \% \\ \text { Palmolive } & 7 & 0.9 \% \\ \text { Schwarzkopf } & 6 & 0.7 \% \\ \text { Vidal Sassoon } & 3 & 0.4 \% \\ \text { Kritvat } & 1 & 0.1 \% \\ \text { Thimotei } & 1 & 0.1 \% \\ \text { Anders } & 40 & 5.0 \% \\ \text { weet niet } & 84 & 10.5 \%\end{array}$




\section{Involvement}

Waarden (min. score 11; max. score 55)

11-19

20-28

29-37

38-46

47-55

Gemiddelde: $\quad 42.4$

Std.dev.: $\quad 11.4$

\section{Commitment}

Waarden ( min.score 6; max. score 30)

6-10

11-15

16-20

21-25

26-30

Gemiddelde: $\quad 21.3$

Std.dev.:

7.8

\section{Deliberatie}

Waarden (min. score 6; max. score 30)

6-10

11-15

16-20

21-25

26-30

Gemiddelde: $\quad 13.8$

Std.dev.: $\quad 5.5$

5.5

Frequentic Percentage

33

$4.7 \%$

$47 \quad 6.9 \%$

$102 \quad 15.0 \%$

$158 \quad 23.4 \%$

$314 \quad 46.8 \%$
Frequentie Percentage

$96 \quad 13.3 \%$

$103 \quad 14.2 \%$

$112 \quad 15.4 \%$

$114 \quad 15.6 \%$

$304 \quad 41.7 \%$

$\begin{array}{ll}\text { Frequentie } & \text { Percentage } \\ 203 & 32.1 \% \\ 187 & 29.6 \% \\ 162 & 25.6 \% \\ 64 & 10.1 \% \\ 15 & 2.4 \%\end{array}$




\section{Algemene Gegevens}

\section{Vraag 2 Leeftijd}

Leeftijd Frequentie Percentage

\section{AGB1991}

0- 9

$10-19$

13

201

20-29

30-39

225

40-49

154

119

67

13

2

$1.6 \%$

$25.2 \%$

$28.3 \%$

$19.6 \%$

$14.9 \%$

$8.4 \%$

$1.9 \%$

$0.2 \%$
$12.2 \%$

$13 \%$

$17.1 \%$

$15.9 \%$

$14.2 \%$

$10.2 \%$

$8.7 \%$

$5.8 \%$

$3 \%$

Gemiddelde: $39.8 \quad$ Std.dev.: 13.9

\section{Vraag 3 Beroepen}

$\begin{array}{lrrr}\text { Beroepen } & \text { Frequentie } & \text { Percentage } & \text { AGB1 } \\ \text { Bedrijfshoofden en Vrije Beroepen } & 21 & 2.7 \% & 8.3 \% \\ \text { Hogere Employees } & 65 & 8.5 \% & 5.1 \% \\ \text { Middelbare Employees } & 182 & 23.8 \% & 18.2 \% \\ \text { Lagere Employees } & 81 & 10.6 \% & 9.0 \% \\ \text { Geschoolde Arbeiders } & 16 & 2.1 \% & 11.3 \% \\ \text { Ongeschoolde Arbeiders } & 22 & 2.9 \% & 7.0 \% \\ \text { Werkloos } & 9 & 1.2 \% & 6.3 \% \\ \text { Arbeidsongeschikt/WAO } & 17 & 2.2 \% & 4.9 \% \\ \text { Gepensioneerd/ Vut } & 39 & 5.1 \% & 23.4 \% \\ \text { Studerend } & 66 & 8.6 \% & 4.7 \% \\ \text { Huisvrouw/ Zonder werk } & 247 & 32.3 \% & 1.6 \%\end{array}$

Vraag 4 Uit hoeveel personen bestaat uw huishouden, uzelf meegerekend?

$\begin{array}{lcrc}\text { Personen } & \text { Frequentie } & \text { Percentage } & \text { AGB } 1991 \\ \text { Huishouden } & & & \\ 1 & 160 & 20.8 \% & 30 \% \\ 2 & 260 & 33.8 \% & 32 \% \\ 3 & 132 & 17.1 \% & 15 \% \\ 4 & 160 & 20.8 \% & 17 \% \\ 5 & 51 & 6.6 \% & 5 \% \\ 6 & 7 & 0.9 \% & 1 \%\end{array}$

Gemiddelde: $2.6 \quad$ Std.dev.: 1.3 


\section{BULLAGE 11.1: De advertentie}

\section{GEZOCHT: CONSUMENTEN}

De Economische Faculteit van de Rijksuniversiteit Limburg is op zoek naar consumenten (18 jaar en ouder) die mee willen werken aan een onderzoek naar het herhaald kopen van alledaagse produkten.

Uw medewerking bestaat uit het thuis invullen van een vragenlijst. De vragen gaan over de manier waarop u bepaalde produkten koopt (o.m. zeep, koffie, shampoo, cassettebandjes, kleding).

Het invullen van de lijst vergt circa 25 minuten. Uw antwoorden worden strikt vertrouwelijk behandeld.

\section{Wilt u meedoen?}

Meldt $\mathrm{u}$ dan aan met onderstaande bon die $\mathrm{U}$ in een ongefrankeerde enveloppe kunt zenden aan:

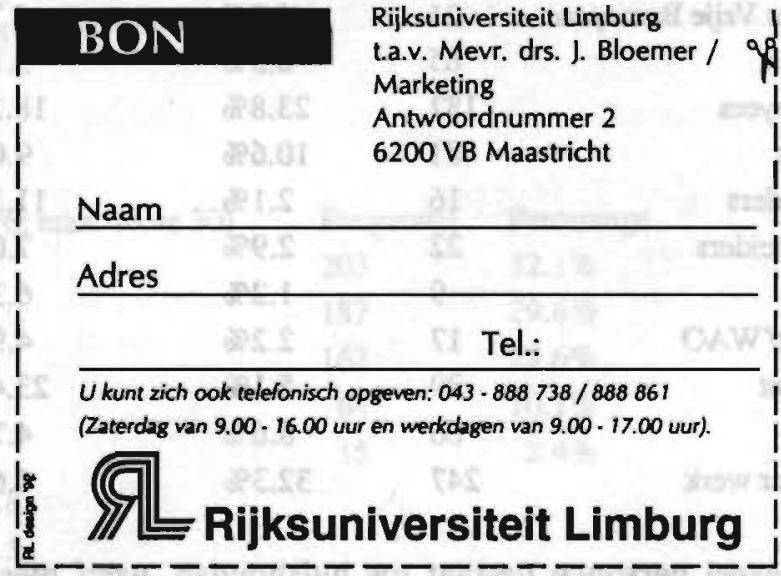


Van onze verslaggever Wie ontevreden is over de koffie die $\mathrm{xij} / \mathrm{hij}$ gekocht heeft, zal het betreffende merk bij een volgende aanmerk bij een volgende aan schaplijstje schrijven. schappenlijstje schrijven. Dat betekent echter niet dat een tevreden hlant een volgende keer wel automatisch

Drs. José Bloemer, docente marketing aan de Rijksuniversiteit limburg neemt in een onderzoek juist die laatste groep de teuredenen. onder de loep $\mathrm{Zij}$ wil de redenen blootleggen die een redenten consument trour maakt of hem juist overhalen om toch over stappen op en ander merk.

\section{Open deur}

„Het lijkt op het intrappen van een open deur", zegt José Bloemer, om te verouderstellen dat tevredenheid een rol speelt bij het cnt staan en voortbestaan van merkentrouw. Maar dat is nooit wetenschappelijk aangetoond. Er zijn vele onderzoeken geweest naar de klachten die ontevreden klanten hebben en hoe ze daar mee omgaan. Maar naar de consument die niets te klagen heeft is nog nooit omgekeken."

Bloemer blijven lang niet alle tevreden consumenten hun merk trouw en zijn de ontevredenen evenmin per definitie on trouw. "Er kunnen allerle redenen zijn voor een tevreden consument om toch over te stappen op een ander merk: een aanbieding
"Merkentrouw maakt het leven gemakkelijker"

Universiteit zoekt tevreden consumenten

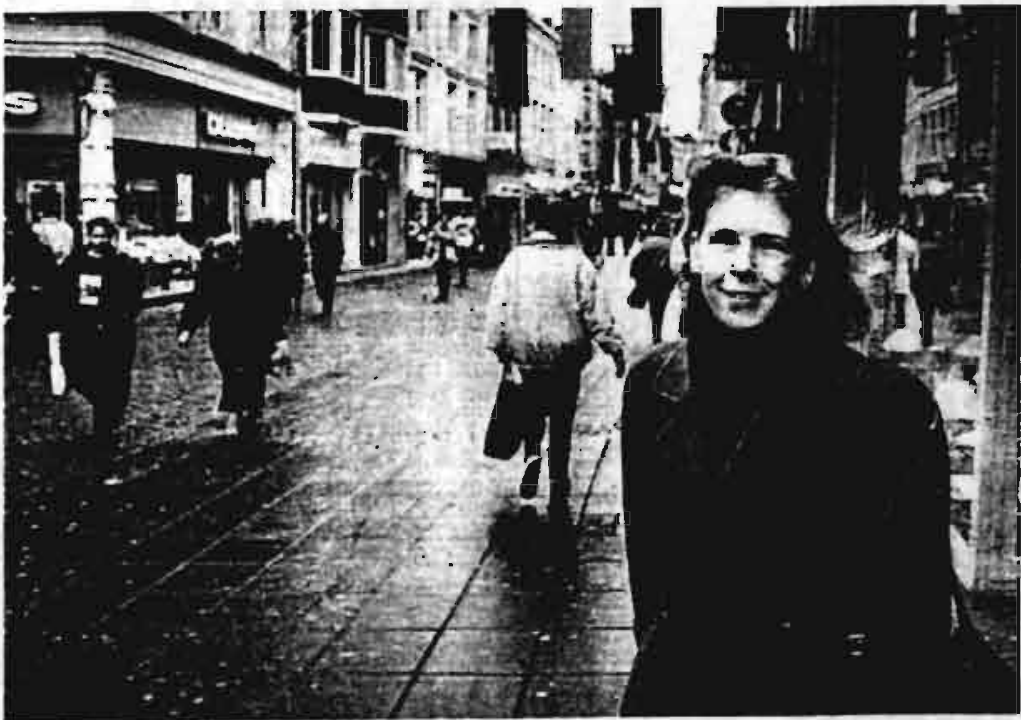

- Drs. José Bloemer is op zoek naar tevreden consumenten. „Merkentrouw maakt het leven een stuk gemakkelijker."

FO:O FRANS WELTERS

bijvoorbeeld, of de betere verkrijgbaarheid van een ander artikel. Maar wie oorzaken aan te geven. Dat moet uit het onderzoek blij-

Omgekeerd kan een onte- vreden klant ook zijn redenen hebben om niet over te van de concurrent. Jose
Bloemer: „Het kan teveel moeite of geld kosten of een alternatief kan zelfs helemaal niet voorhanden zijn - kijk maar naar gas en elektriciteit. Maar er is nog iets: als je over wilt stappen op een ander merk, moet je daar weer over gaan nadenken en alle mogelijkheden opnieuw met elkaar vergelijken. Mensen zijn vaak gemakzuchtig en blijven dan maar liever bij hun oude merk."

\section{Makkelijker}

Hierin schuilt volgens Bloe mer ook het belang van haar onderzoek. "Merkentrou makt het leven een stuk gemakkelijker. Je hoeft niet lelkens opnieuw keuzes te maken. Bovendien voel een consument zich een stuk prettiger als hij tevreden is. De producent moet er dus in het belang van zichzelf en van de consument voor zorgen dat die situatie bereik wordt.

Tot op heden heef: Bloemer zich, in samenwerking met haar promotor prof.dr. Kasper, beziggehouden met lingonderzoek en een peiten $\mathrm{Nu}$ is zij op zoek naar ten. Nu is zijop zoek naa profpersonen die op een proefpersonen die op een redrag in kart wi bre gedrag in kaart willen brengen en omschrijven. Geinte resseerden kunnen zich melden bi de marketing sectie van de economisch laculceit van de RL. Zoda me er uiteindelijk achterkoje koffie (niet) koopt. 


\section{Consumentenonderzoek door Universiteit}

Koopt u steeds opnieuw hetzelfde merk koffie, thee, waspoeder etc. of wisselt $u$ voortdurend van merk? Waarom koopt u van sommige produkten steeds hetzelfde merk en wisselt bij andere produkten vaak van merk? Speelt uw tevredenheid met het merk een rol bij de beslissing om een merk opnieuw te kopen? Dit zijn vragen waarop mevr. J. Bloemer, docente marketing aan de Rijksuniversiteit Limburg, graag een antwoord zou willen hebben. Wanneer $u$ ontevreden bent over een produkt zult u het produkt niet snel opnieuw gaan kopen. Toch zijn er ontevreden consumenten die, om wat voor reden dan ook, niet overstappen naar de concurrent. Maar wat doet $u$ als $u$ tevreden bent met het produkt. Het ene produkt koop u misschien opnieuw, het andere toch maar niet. Dat kan zijn omdat een ander merk in de aanbieding is, of omdat men eens wat anders wil proberen. In het eerste geval bent u merkentrouw, in het tweede geval niet. Via een onderzoek is het de bedoeling na te gaan welke redenen consumenten hebben om merkentrouw te zijn, of die hem/ haar juist overhalen om een ander merk te kopen.

Inmiddels zijn al enige studenten ondervraagd over hun koopgedrag. De RL wil het onderzoek echter uitbei- den en zoekt darom 1000 tot 1500 consumenten die bereid zijn een vragenlijst in te vullen. Wie wil meewerken aan het onderzoek kan contact opnemen met de sectie Marketing van de Economische Faculteit van de Rijksuniversiteit Limburg onder tel:043-888738 043-888861. 


\section{Cassettebandjes}

Merkkeuze-involvement (verticaal) x Commitment (horizontaal)

(laaste twee cijfers komen overeen met vraagnummer in de vragenlijst)

\begin{tabular}{|c|c|c|c|c|c|c|c|c|c|c|}
\hline Correlatie: & : & 0112 & 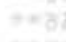 & 0114 & & 0120 & $*+$ & 0123 & 0125 & 0131 \\
\hline $\begin{array}{l}0111 \\
0115 \\
0116 \\
0117 \\
0119 \\
0121 \\
0122 \\
0126 \\
0127 \\
0130 \\
0133\end{array}$ & 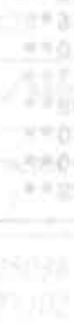 & 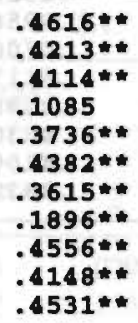 & 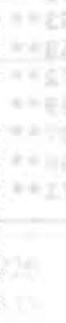 & 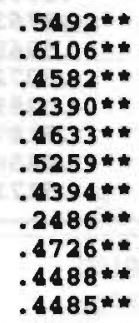 & 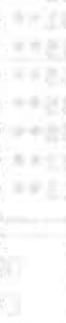 & 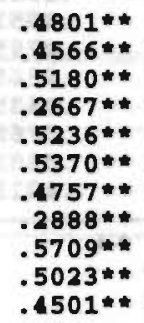 & . & 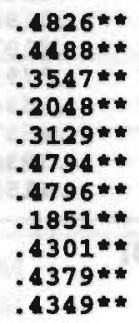 & $\begin{array}{l}.4402 * * \\
.3744 * \\
.3355 * * \\
.1438 * \\
.3272 * * \\
.5089 * * \\
.4038 * * \\
.2622 * \\
.4141 * * \\
.3967 * * \\
.4594 * *\end{array}$ & $\begin{array}{l}.5202 * * \\
.5512 * * \\
.5500 * * \\
.3224 * * \\
.4688 * * \\
.5352 * * \\
.5561 * * \\
.3071 * * \\
.5700 * * \\
.5425 * * \\
.6122 * *\end{array}$ \\
\hline
\end{tabular}

$\mathrm{n}=356 ;{ }^{*}: \mathrm{p}<.01 ;{ }^{* *}: \mathrm{p}<.001$

Merkkeuze-involvement (verticaal) x Deliberatie (horizontaal)

(laatste twee cijfers komen overeen met vraagnummer in de vragenlijst)

\begin{tabular}{|c|c|c|c|c|c|c|}
\hline Correlatie: & 0113 & 0118 & 0124 & 0128 & 0129 & 0132 \\
\hline $\begin{array}{l}0111 \\
0115 \\
0116 \\
0117 \\
0119 \\
0121 \\
0122 \\
0126 \\
0127 \\
0130 \\
0133\end{array}$ & $\begin{array}{l}.2258 * * \\
.1274 \\
.2376 * * \\
.2518^{*} \\
.3424 * \\
.2012 * * \\
.1531 * \\
.2162 * * \\
.2364^{*} \\
.1410^{*} \\
.1522 *\end{array}$ & $\begin{array}{l}.1767 * * \\
.1560^{*} \\
.2895 * * \\
.1890^{* *} \\
.3905 * * \\
.1969 * * \\
.1466 * \\
.2371 * * \\
.3116 * * \\
.1549 * \\
.1938 *\end{array}$ & $\begin{array}{l}.2724 * * \\
.2346 * \star \\
.3163 * * \\
.2137 * \\
.3770^{*} \\
.2772 * \\
.2134^{*} \\
.1999 * \\
.2981 * \\
.2295 * \\
.1687\end{array}$ & $\begin{array}{l}.3527 * \star \\
.2261 * \star \\
.3345 * * \\
.2758 * * \\
.3591 * \\
.2984 * \\
.2991 * \\
.2434 * \\
.3709 * \\
.3023 * \\
.2934 *\end{array}$ & $\begin{array}{l}.1970 * \\
.2037 * * \\
.3489 * \\
.2211 * \\
.3392 * \\
.1902 * * \\
.1841 * * \\
.1088 \\
.2775 * \\
.1941 * \\
.1412\end{array}$ & 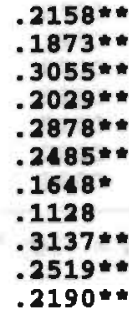 \\
\hline
\end{tabular}

$\mathrm{n}=322 ; *$ :p<.01; ${ }^{* *}: \mathrm{p}<.001$

Commitment (verticaal) x Deliberatie (horizontaal)

(laatste twee cijfers komen overeen met vraagnummer in de vragenlijst)

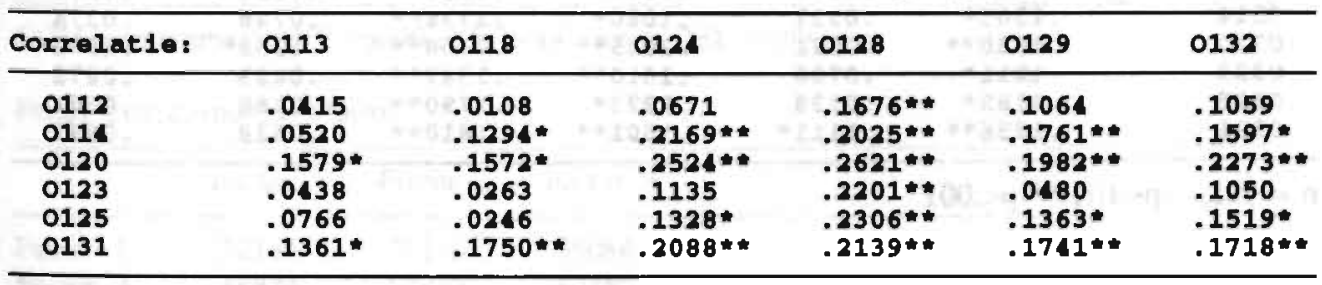

$\mathrm{n}=370 ; *: \mathrm{p}<.01 ; * * \mathrm{p}<.001$ 
Merkkeuze-involvement (verticaal) x Commitment (horizontaal)

(laatste twee cijfers komen overeen met vraagnummer in de vragenlijst)

\begin{tabular}{|c|c|c|c|c|c|c|}
\hline Correlatie: & 0312 & 0314 & 0320 & 0323 & 0325 & 0331 \\
\hline $\begin{array}{l}0311 \\
0315 \\
0316 \\
0317 \\
0319 \\
0321 \\
0322 \\
0326 \\
0327 \\
0330 \\
0333\end{array}$ & $\begin{array}{l}.3249 * * \\
.4117 * * \\
.4315 * * \\
.1437 * * \\
.3132 * * \\
.4088 * * \\
.3385 * * \\
.2307 * * \\
.4302 * * \\
.3490 * * \\
.3407 * *\end{array}$ & $\begin{array}{l}.4017 * * \\
.5218 * * \\
.4335 * * \\
.2241 * * \\
.3190 * * \\
.4107 * * \\
.3791 * \\
.2684 * \\
.4537 * * \\
.3938 * * \\
.4155 * *\end{array}$ & $\begin{array}{l}.4152 * * \\
.4865 * \\
.5310^{*} \\
.2550 * \\
.4551 * \\
.4795 * \\
.4365 * \\
.3485 * \\
.5768 * \\
.4303^{*} \\
.4213^{*}\end{array}$ & $\begin{array}{l}.4883^{*} * \\
.6490^{*} \\
.4866^{*} \\
.2985 * \\
.3763 * \\
.5968 * \\
.5072 * \\
.3299 * \\
.5187 * \\
.4456 * \\
.5171 *\end{array}$ & 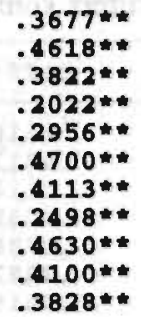 & $\begin{array}{l}.4225 * * \\
.5646 * * \\
.4872 * * \\
.2868 * * \\
.3385 * * \\
.5094 * \\
.4554 * \\
.3617 * \\
.5197 * * \\
.4768 * \star \\
.5217 * *\end{array}$ \\
\hline
\end{tabular}

$\mathrm{n}=496 ;{ }^{*}: \mathrm{p}<.01 ; * *: \mathrm{p}<.001$

Merkkeuze-involvement (verticaal) x Deliberatie (horizontaal)

(laatste twee cijfers komen overeen met vraagnummer in de vragenlijst)

\begin{tabular}{|c|c|c|c|c|c|c|}
\hline Correlatie: & 0313 & 0318 & 0324 & 0328 & 0329 & 0332 \\
\hline $\begin{array}{l}0311 \\
0315 \\
0316 \\
0317 \\
0319 \\
0321 \\
0322 \\
0326 \\
0327 \\
0330 \\
0333\end{array}$ & $\begin{array}{l}.1112 \star \\
.1772 * \star \\
.2681 * \\
.1790 * \\
.3457 * \\
.1543 * \star \\
.1292 \star \\
.2097 \star \star \\
.2946 \star \\
.2129 * \\
.1801 *\end{array}$ & 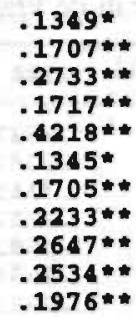 & 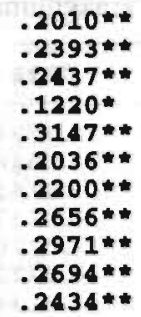 & $\begin{array}{l}.2702 * * \\
.2505 * * \\
.2033 * * \\
.1129 * \\
.3055 * \\
.2248 * \\
.2211 * \\
.1765 * \\
.2767 * \\
.2368 * \\
.2755 *\end{array}$ & $\begin{array}{l}.1529 * \\
.1788^{*} \\
.1862 * \\
.0982 \\
.2778 * \\
.1049 \\
.1567 * \\
.1547 * \\
.2286 * \\
.1613 * \\
.1391\end{array}$ & $\begin{array}{l}.0259 \\
.0877 \\
.1344^{*} \\
.0561 \\
.1401 \\
.0938 \\
.0804 \\
.0828 \\
.1392 \\
.0367 \\
.0600\end{array}$ \\
\hline
\end{tabular}

n $=480 ; *: p<.01 ; * *$ p $<.001$

Commitment (verticaal) $\times$ Deliberatie (horizontaal)

(laatste twee cijfers komen overeen met vraagnummer in de vragenlijst)

\begin{tabular}{|c|c|c|c|c|c|c|}
\hline Corralatie: & 0313 & 0318 & 0324 & 0328 & 0329 & 0332 \\
\hline $\begin{array}{l}0312 \\
0314 \\
0320 \\
0323 \\
0325 \\
0331\end{array}$ & $\begin{array}{l}.0267 \\
.1305 \\
.1830 * \\
.1211 \\
.1182 \\
.1756\end{array}$ & $\begin{array}{l}.0128 \\
.0237 \\
.0911 \\
.0780 \\
.0138 \\
.1111\end{array}$ & $\begin{array}{l}.0549 \\
.1060 * \\
.2089 * \\
.1610 * \\
.1273 * \\
.1501 *\end{array}$ & $\begin{array}{l}.0856 \\
.1734 \\
.2358 \\
.1587 \\
.179 \\
.1810\end{array}$ & $\begin{array}{c}-.0628 \\
.0728 \\
.1256 \\
.0483 \\
.0368 \\
.0528\end{array}$ & $\begin{array}{l}.0236 \\
.0374 \\
.1573 \\
.0275 \\
.0502 \\
.0893\end{array}$ \\
\hline
\end{tabular}

$\mathrm{n}=523{ }^{*}: \mathrm{p}<.01 ;{ }^{* *}: \mathrm{p}<.001$ 
Tabel 13.1: Factoranalyse alle items (PCA: varimax rotatie, max. 3 factoren)

\section{Cassettebandjes}

\begin{tabular}{llll}
\hline Factor & Eigenwaarde & Perc Var & Cum Perc \\
\hline 1 & 9.15067 & 39.8 & 39.8 \\
2 & 2.54966 & 11.1 & 50.9 \\
3 & 1.18428 & 5.1 & 56.0 \\
\hline
\end{tabular}

Rotated Factor Matrix:

\begin{tabular}{|c|c|c|c|c|c|c|}
\hline Vraag & $\begin{array}{c}\text { Factor } \\
1\end{array}$ & 2 & 3 & Schaal & Communaliteit & \\
\hline 12 & .76038 & .07926 & .00130 & COM & .58446 & \\
\hline 14 & .77102 & .17535 & .12913 & COM & .64190 & \\
\hline 20 & .73416 & .21154 & .22988 & $\mathrm{COM}$ & .63659 & \\
\hline 23 & .70882 & .19952 & -.02032 & COM & .54265 & \\
\hline 25 & .77918 & .05347 & .09415 & $\mathrm{COM}$ & .61885 & \\
\hline 31 & .64078 & .43519 & .10443 & COM & .61089 & \\
\hline 11 & .36892 & .58305 & .21672 & INV & .52303 & \\
\hline 15 & .54679 & .49026 & .11259 & INV & .55201 & \\
\hline 16 & .47403 & .45189 & .36602 & INV & .56288 & \\
\hline 17 & .02118 & .71140 & .19537 & INV & .54471 & \\
\hline 19 & .41065 & .43584 & .45838 & INV & .56870 & \\
\hline 21 & .55515 & .55639 & .15856 & INV & .64289 & \\
\hline 22 & .46198 & .65129 & .07909 & INV & .64385 & \\
\hline 26 & .09208 & 57146 & .16323 & INV & .36169 & \\
\hline 27 & .50480 & .53529 & .31863 & INV & .64288 & \\
\hline 30 & .47692 & .61652 & .13546 & INV & .62590 & \\
\hline 33 & .52741 & 57906 & .08069 & INV & .61998 & \\
\hline 13 & -.04154 & .14938 & .72927 & DEL & .55587 & \\
\hline 18 & -.06304 & .24095 & .65548 & DEL & .49168 & \\
\hline 24 & .09081 & .13257 & .72529 & $\overline{\mathrm{DEL}}$ & .55187 & \\
\hline 28 & .19521 & .19065 & .60148 & DEL & .43624 & \\
\hline 29 & .11713 & .02220 & .71317 & DEL & .52282 & \\
\hline 32 & .18613 & .03122 & .60553 & DEL & .40229 & \\
\hline
\end{tabular}

COM: commitment; INV: merkkeuze-involvement; DEL: deliberatie

Factor Transformation Matrix:

\begin{tabular}{llll}
\hline & Factor 1 & Factor 2 & Factor 3 \\
\hline Factor 1 & .72139 & .57170 & .39084 \\
Factor 2 & -.48823 & .01957 & .87250 \\
Factor 3 & .49116 & -.82023 & .29324 \\
\hline
\end{tabular}


Tabel 13.2: Factoranalyse alle items (PCA: varimax rotatie, max. 3 factoren)

\section{Haarshampoo}

\begin{tabular}{llll}
\hline Factor & Eigenwaarde & Perc Var & Cum Perc \\
\hline 1 & 8.74798 & 38.0 & 38.0 \\
2 & 2.49338 & 10.8 & 48.9 \\
3 & 1.21587 & 5.3 & 54.2 \\
\hline
\end{tabular}

Rotated Factor Matrix:

\begin{tabular}{|c|c|c|c|c|c|c|c|}
\hline Vraag & $\begin{array}{c}\text { Factor } \\
1\end{array}$ & 2 & 3 & Schaal & & Communaliteit & \\
\hline 11 & .60073 & .33879 & .06112 & INV & & .47939 & \\
\hline 15 & .70227 & .44617 & .08827 & INV & & .70004 & \\
\hline 16 & .61445 & .37329 & .24042 & INV & & .57469 & \\
\hline 17 & 56451 & .03018 & .06345 & INV & & .32361 & \\
\hline 19 & .63557 & .17299 & .39773 & INV & & .59206 & \\
\hline 21 & .65732 & .43004 & .04259 & INV & & .61882 & \\
\hline 22 & .69178 & .33037 & .06424 & INV & & .59182 & \\
\hline 26 & .44937 & .19734 & .23307 & INV & & .29520 & \\
\hline 27 & .58506 & .45126 & .29669 & INV & & .63396 & \\
\hline 30 & .60938 & .32429 & .17258 & INV & & .50629 & \\
\hline 33 & .66839 & .33436 & .11140 & INV & & .57095 & \\
\hline 12 & .23782 & .67148 & -.03710 & $\mathrm{COM}$ & & .50882 & \\
\hline 14 & .26882 & .70141 & .05824 & $\mathrm{COM}$ & & .56763 & \\
\hline 20 & .28601 & .74631 & .19968 & $\mathrm{COM}$ & & .67865 & \\
\hline 23 & .48012 & .64338 & .00456 & $\mathrm{COM}$ & & .64447 & \\
\hline 25 & .20109 & .80363 & .05447 & $\mathrm{COM}$ & & .68923 & \\
\hline 31 & .37777 & .70330 & .06904 & $\mathrm{COM}$ & & .64211 & \\
\hline 13 & .19929 & -.03162 & .70728 & DEL & & .54097 & \\
\hline 18 & .37223 & -.22334 & .60363 & DEL & & .55281 & \\
\hline 24 & .25082 & -.01419 & .69371 & DEL & & .54435 & \\
\hline 28 & .12114 & .18425 & 58307 & DEL & & .38859 & \\
\hline 29 & .05747 & .04543 & .64747 & $\mathrm{DEL}$ & & .42458 & \\
\hline 32 & -.18841 & .21534 & 55345 & DEL & & .38818 & \\
\hline
\end{tabular}

COM: commitment; INV: merkkeuze-involvement; DEL: deliberatie

Factor Transformation Matrix:

\begin{tabular}{llrl}
\hline & Factor 1 & Factor 2 & Factor 3 \\
\hline Factor 1 & .72205 & .62129 & .30436 \\
Factor 2 & .05069 & -.48626 & .87234 \\
Factor 3 & -.68998 & .61445 & .38260 \\
\hline
\end{tabular}


BLJLAGE 14: t-toetsen voor het verschil in gemiddelde scores voor de twee produkten

Tabel 14.1: t-toetsen met als basis de twee produkten

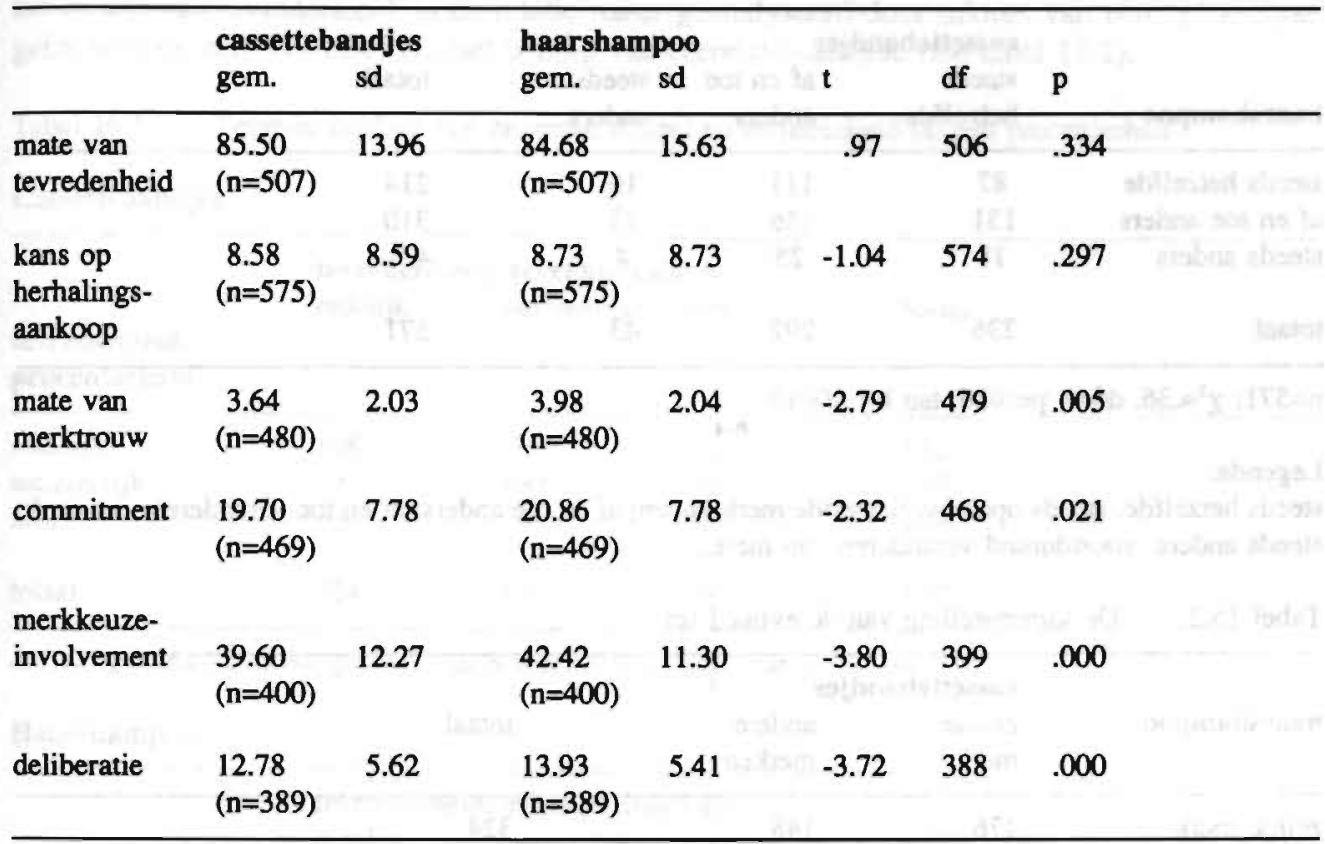

Het gemiddelde niveau van commitment, merkkeuze-involvement en deliberatie is hoger bij haarshampoo dan bij cassettebandjes. Wellicht dat dit veroorzaakt wordt door het persoonlijke karakter van haarshampoo in tegenstelling tot cassettebandjes. 
BLJLAGE 15: $\quad \chi^{2}$-toets voor het verschil voor wat betreft de samenstelling van de evoked set en de manier van heraankopen

Tabel 15.1: De manier van heraankopen

\begin{tabular}{lcccl}
\hline & \multicolumn{2}{l}{ cassettebandjes } & & \\
steeds & & $\begin{array}{l}\text { af en toe } \\
\text { anders }\end{array}$ & $\begin{array}{l}\text { steeds } \\
\text { anders }\end{array}$ & totaal \\
haarshampon & 87 & 111 & 16 & 214 \\
\hline steeds hetzelfde & 131 & 156 & 23 & 310 \\
af en toe anders & 18 & 25 & 4 & 47 \\
steeds anders & 236 & 292 & 43 & 571 \\
totaal & & & & \\
\hline
\end{tabular}

$\mathrm{n}=571 ; \chi^{2}=.36, \mathrm{df}=4, \mathrm{p}=.986 ;$ tau $\mathrm{b}=-.0010$

Legenda:

steeds hetzelfde: steeds opnieuw hetzelfde merk kopen; af en toe anders: af en toe veranderen van merk; steeds anders: voortdurend veranderen van merk.

Tabel 15.2: De samenstelling van de evoked set

\begin{tabular}{llll}
\hline \multirow{2}{*}{ haarshampoo } & \multicolumn{2}{l}{ cassettebandjes } \\
& $\begin{array}{l}\text { zelfde } \\
\text { merk }\end{array}$ & $\begin{array}{l}\text { andere } \\
\text { merken }\end{array}$ & totaal \\
\hline zelfde merk & 176 & 148 & 324 \\
andere merken & 109 & 139 & 248 \\
totaal & 285 & 287 & 572 \\
\hline
\end{tabular}

$\mathrm{n}=572 ; \chi^{2}=6.04, \mathrm{df}=1, \mathrm{p}=.014 ; \mathrm{phi}=.10278$

Legenda:

zelfde merk: evoked set bevat alleen het laatst gekochte merk; andere merken: evoked set bevat ook andere merken. 
Voor een nadere analyse van de relatie tussen de zevenpuntsschaal en de procentschaal voor het meten van tevredenheid, is de relatie nader geanalyseerd door middel van een $\chi^{2}$ analyse gebaseerd op een $3 \times 3$ tabel en met behulp van correlatie-analyse (zie tabel 17.1).

Tabel 16.1: Tevredenheid op een zevenpuntschaal en tevredenheid op een procentschaal

\section{Cassettebandjes}

\begin{tabular}{|c|c|c|c|c|}
\hline $\begin{array}{l}\text { tevredenheid: } \\
\text { procentschaal }\end{array}$ & $\begin{array}{l}\text { tevreder } \\
\text { redelijk }\end{array}$ & $\begin{array}{l}\text { : zevenpunt: } \\
\text { aanzienlijk }\end{array}$ & $\begin{array}{l}\text { haal } \\
\text { zeer }\end{array}$ & totaal \\
\hline redelijk & 108 & 23 & 1 & 132 \\
\hline aanzienlijk & 8 & 160 & 29 & 197 \\
\hline zeer & 8 & 5 & 170 & 183 \\
\hline totaal & 124 & 191 & 200 & 512 \\
\hline \multicolumn{5}{|c|}{$n=512 ; \chi^{2}=564,76, d f=4, p=.000 ;$ tau $b=.77275 ;$ pearson cor $=.77, p=.000$} \\
\hline \multicolumn{5}{|l|}{ Haarshampoo } \\
\hline $\begin{array}{l}\text { tevredenheid: } \\
\text { procentschaal }\end{array}$ & $\begin{array}{l}\text { tevreder } \\
\text { redelijk }\end{array}$ & $\begin{array}{l}\text { : zevenpunts } \\
\text { aanzienlijk }\end{array}$ & $\begin{array}{c}\text { chaal } \\
\text { zeer }\end{array}$ & totaal \\
\hline redelijk & 170 & 36 & 6 & 212 \\
\hline aanzienlijk & 58 & 204 & 43 & 305 \\
\hline zeer & 9 & 9 & 227 & 245 \\
\hline totaal & 237 & 249 & 276 & 762 \\
\hline
\end{tabular}

$\mathrm{n}=762 ; \chi^{2}=747.98, \mathrm{df}=4, \mathrm{p}=.000 ;$ tau $\mathrm{b}=.75493 ;$ pearson cor $=.76, \mathrm{p}=.000$

Legenda:

Zevenpuntsschaal redelijk tevreden: respondenten die $1 \mathrm{t} / \mathrm{m} 5$ scoorden op de zevenpuntsschaal ( $1=$ enigszins tevreden en $7=$ zeer tevreden); aanzienlijk tevreden: respondenten die 6 scoorden op de zevenpuntsschaal; zeer tevreden: respondenten die 7 scoorden op de zevenpuntsschaal.

Procentschaal

redelijk tevreden: al die respondenten die te kennen hebben gegeven voor $75 \%$ of minder tevreden te zijn;

aanzienlijk tevreden: respondenten die te kennen gaven voor $76 \% \mathrm{t} / \mathrm{m} 99 \%$ procent tevreden te zijn;

zeer tevreden: $\quad$ respondenten die voor $100 \%$ tevreden zijn. 
Slechts $15 \%(n=76)$ van de waamemingen inzake cassettebandjes en slechts $21 \%(n=161)$ van de waarnemingen voor haarshampoo bevinden zich buiten de diagonaal. Tau b en de Pearson correlatie-coëfficiënt kunnen worden geïnterpreteerd als een associatie- maat, die kan variëren tussen -1 en +1 , waarbij +1 perfecte associatie aangeeft. Deze maat is voor beide produkten groter dan .75 .

Voor beide produkten kan daarom worden aangenomen dat de zevenpuntsschaal en de procentschaal niet met exact dezelfde maat meten. De procentschaal bevat echter meer en gevoeliger informatie dan de zevenpuntsschaal, zodat in het vervolg bij de analyses gebruik zal worden gemaakt van de procentschaal. 


\section{BIJLAGE 17: $\quad$ Kruistabellen}

Legenda bij de kruistabellen.

De mate van tevredenheid wordt in drie categorieën onderscheiden: redelijk: respondenten die $75 \%$ of minder tevreden zijn; aanzienlijk: respondenten die tussen de $75 \%$ en $100 \%$ tevreden zijn;

zeer: respondenten die voor $100 \%$ tevreden zijn.

De kans op een herhalingsaankoop wordt in drie categorieën onderscheiden: redelijk: respondenten die de kans dat ze hetzelfde produkt opnieuw zullen kopen aangeven op $50 \%$ of minder;

groot: respondenten die de kans dat ze hetzelfde produkt opnieuw zullen kopen aangeven tussen de $50 \%$ en de $100 \%$;

zeer groot: respondenten die de kans dat ze hetzelfde produkt opnieuw zullen kopen aangeven op $100 \%$.

De mate van merktrouw wordt in drie categorieèn onderscheiden:

automatisme:

respondenten die 1 of 2 scoren op de oorspronkelijke schaal en dus sterk neigen naar een automatische herhalingsaankoop;

enigszins merktrouw: respondenten die 3 of 4 scoren op de oorspronkelijke schaal en dus tussen een automatische herhalingsaankoop en een weloverwogen keuze inzitten;

ware merktrouw: respondenten die 5, 6 of 7 scoren op de oorspronkelijk schaal en dus neigen naar een weloverwogen keuze.

Commitment, merkkeuze-involvement en deliberatie worden afhankelijk van de score per produkt ingedeeld in 3 categorieën die elk $33,3 \%$ van de respondenten bevatten:

klein: redelijk:

groot:

laag:

redelijk:

hoog:

weinig: redelijk:

veel: respondenten met de laagste scores voor commitment per produkt; respondenten met gemiddelde scores voor commitment per produkt; respondenten met de hoogste scores voor commitment per produkt.

respondenten met de laagste scores voor merkkeuze-involvement per produkt;

respondenten met gemiddelde scores voor merkkeuze-involvement per produkt:

respondenten met de hoogste scores voor merkkeuze-involvement per produkt.

respondenten met de laagste scores voor deliberatie per produkt; respondenten met gemiddelde scores voor deliberatie per produkt; respondenten met de hoogste scores voor deliberatie per produkt. 
BIJLAGE 17.1: Cassettebandjes

Tabel 17.1: Tevredenheid en de kans op een herhalingsaankoop

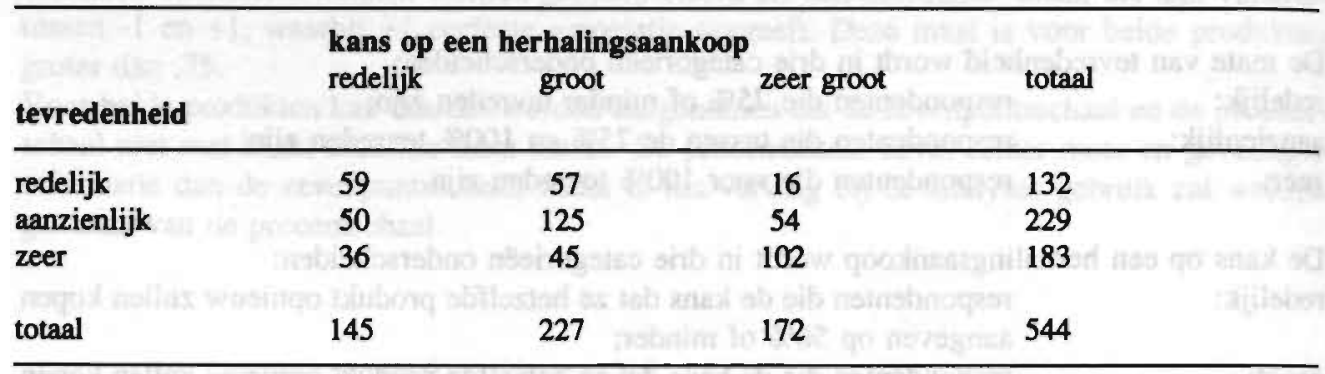

$\chi^{2}=97.70, \mathrm{df}=4, \mathrm{p}=.0000 ;$ tau $\mathrm{b}=.31424$

Tabel 17.2:

Tevredenheid en de manier van heraankopen

\begin{tabular}{llcll}
\hline & $\begin{array}{l}\text { manier van heraankopen } \\
\text { steeds } \\
\text { hetzelfde }\end{array}$ & $\begin{array}{l}\text { af en toe } \\
\text { anders }\end{array}$ & $\begin{array}{l}\text { steeds } \\
\text { anders }\end{array}$ & totaal \\
tevredenheid & 30 & 87 & 15 & 132 \\
\hline redelijk & 82 & 129 & 16 & 227 \\
aanzienlijk & 101 & 75 & 7 & 183 \\
zeer & 213 & 291 & 38 & 542 \\
\hline totaal & & & & \\
\hline
\end{tabular}

$\chi^{2}=37.37, \mathrm{df}=4, \mathrm{p}=.000 ;$ tau $b=-.23988$

Tabel 17.3: $\quad$ Tevredenheid en de mate van merktrouw

\begin{tabular}{llcll}
\hline & \multicolumn{2}{l}{ mate van merktrouw } & & \\
automatisme & enigszins & MT & ware MT & totaal \\
\hline redelijk & 53 & 34 & 29 & 116 \\
aanzienlijk & 66 & 65 & 81 & 212 \\
zeer & 58 & 50 & 65 & 173 \\
totaal & 177 & 149 & 175 & 501 \\
\hline
\end{tabular}

$\chi^{2}=9.12, d f=4, p=.58 ;$ tau $b=.08434$ 
Tevredenheid en de samenstelling van de evoked set

samenstelling evoked set

$\begin{array}{lll}\text { zelfde } & \text { andere } & \text { totaal } \\ \text { merk } & \text { merken } & \end{array}$

tevredenheid

\begin{tabular}{lccc}
\hline redelijk & 55 & 76 & 131 \\
aanzienlijk & 104 & 122 & 226 \\
zeer & 114 & 70 & 184
\end{tabular}

totaal

273

268

541

$\chi^{2}=15.28, \mathrm{df}=2, \mathrm{p}=.00048 ;$ lambda a-symmetrisch $=.14$ (evoked set $=$ dependent)

Tabel 17.5:

Tevredenheid en commitment

\begin{tabular}{llccc}
\hline & $\begin{array}{l}\text { commitment } \\
\text { klein }\end{array}$ & redelijk & groot & totaal \\
tevredenheid & 52 & 37 & 19 & 108 \\
\hline redelijk & 72 & 83 & 55 & 210 \\
aanzienlijk & 39 & 48 & 78 & 165 \\
zeer & 163 & 168 & 152 & 483 \\
totaal & & & & \\
\hline
\end{tabular}

$\chi^{2}=36.11, \mathrm{df}=4, p=.0000 ;$ tau $b=.22860$

Tabel 17.6:

Tevredenheid en merkkeuze-involvement

\begin{tabular}{lcccc}
\hline & \multicolumn{2}{l}{ merkkeuze-involvement } \\
laag & redelijk & hoog & totaal \\
\hline tevredenheid & 46 & 35 & 22 & 103 \\
redelijk & 57 & 73 & 63 & 193 \\
aanzienlijk & 38 & 36 & 66 & 140 \\
zeer & 141 & 144 & 151 & 436 \\
totaal & & & & \\
\hline
\end{tabular}

$\chi^{2}=21.90, \mathrm{df}=4, \mathrm{p}=.0002 ;$ tau $\mathrm{b}=.17403$ 


\begin{tabular}{lllll}
\hline & $\begin{array}{l}\text { deliberatie } \\
\text { weinig }\end{array}$ & redelijk & veel & totaal \\
tevredenheid & 45 & 32 & 31 & 108 \\
redelijk & 50 & 68 & 69 & 187 \\
aanzienlijk & 46 & 43 & 45 & 134 \\
zeer & 141 & 143 & 145 & 429 \\
totaal & & & \\
\hline
\end{tabular}

$\chi^{2}=7.15, d f=4, p=.1280 ;$ tau $b=.04089$ 
BLJLAGE 17.2: Haarshampoo

Tabel 17.8: $\quad$ Tevredenheid en de kans op een herhalingsaankoop

\begin{tabular}{|c|c|c|c|c|c|}
\hline tevredenheid & $\begin{array}{l}\text { kans op } \\
\text { redelijk }\end{array}$ & $\begin{array}{l}\text { erhaling } \\
\text { groot }\end{array}$ & zeer groot & totaal & 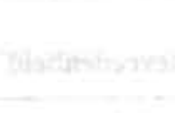 \\
\hline redelijk & 95 & 77 & 38 & 210 & ant \\
\hline aanzienlijk & 63 & 149 & 93 & 305 & \\
\hline zeer & 24 & 48 & 176 & 248 & \\
\hline totaal & 182 & 274 & 307 & 763 & \\
\hline
\end{tabular}

$\chi^{2}=186.64, \mathrm{df}=4, \mathrm{p}=.0000 ;$ tau $\mathrm{b}=.40645$

Tabel 17.9: Tevredenheid en de manier van heraankopen

\begin{tabular}{lllll}
\hline & $\begin{array}{l}\text { manier van heraankopen } \\
\text { steeds } \\
\text { hetzelfde }\end{array}$ & $\begin{array}{l}\text { af en toe } \\
\text { anders }\end{array}$ & $\begin{array}{l}\text { steeds } \\
\text { anders }\end{array}$ & totaal \\
tevredenheid & 43 & 138 & 27 & 208 \\
\hline redelijk & 129 & 159 & 16 & 304 \\
aanzienlijk & 158 & 82 & 6 & 246 \\
zeer & 330 & 379 & 49 & 758 \\
totaal & & & & \\
\hline
\end{tabular}

$\chi^{2}=94.86, d f=4, p=.000 ;$ tau $b=-.32306$

Tabel 17.10: $\quad$ Tevredenheid en de mate van merktrouw

\begin{tabular}{|c|c|c|c|c|}
\hline tevredenheid & $\begin{array}{l}\text { mate van mer } \\
\text { automatisme }\end{array}$ & $\begin{array}{l}\text { ktrouw } \\
\text { enigszins MT }\end{array}$ & ware MT & totaal \\
\hline redelijk & 69 & 65 & 49 & 183 \\
\hline aanzienlijk & 80 & 79 & 127 & 286 \\
\hline zeet & 65 & 43 & 129 & 237 \\
\hline totaal & 214 & 187 & 305 & 706 \\
\hline
\end{tabular}

$\chi^{2}=34.91, \mathrm{df}=4, \mathrm{p}=.0000 ;$ tau $\mathrm{b}=.15539$ 
Tabel 17.11: $\quad$ Tevredenheid en de samenstelling van de evoked set

\begin{tabular}{llll}
\hline & $\begin{array}{l}\text { samenstelling evoked set } \\
\text { zelfde } \\
\text { merk }\end{array}$ & $\begin{array}{l}\text { andere } \\
\text { merken }\end{array}$ & totaal \\
tevredenheid & 97 & 111 & 208 \\
\hline redelijk & 179 & 125 & 304 \\
aanzienlijk & 181 & 67 & 248 \\
zeer & 457 & 303 & 760 \\
\hline
\end{tabular}

$\chi^{2}=29.44, \mathrm{df}=2, \mathrm{p}=.000$; lambda a-symmetrisch=.007 (evoked set $=$ dependent)

Tabel 17.12: $\quad$ Tevredenheid en commitment

\begin{tabular}{lcccc}
\hline & $\begin{array}{l}\text { commitment } \\
\text { klein }\end{array}$ & redelijk & groot & totaal \\
tevredenheid & 98 & 65 & 28 & 191 \\
\hline redelijk & 82 & 100 & 93 & 275 \\
aanzienlijk & 42 & 81 & 103 & 226 \\
zeer & 222 & 246 & 224 & 692 \\
totaal & & & & \\
\hline
\end{tabular}

$\chi^{2}=66.32, \mathrm{df}=4, p=.0000 ;$ tau $b=.27001$

Tabel 17.13: $\quad$ Tevredenheid en merkkeuze-involvement

\begin{tabular}{|c|c|c|c|c|}
\hline tevredenheid & $\begin{array}{l}\text { merl } \\
\text { laag }\end{array}$ & $\begin{array}{l}\text { olvement } \\
\text { redelijk }\end{array}$ & hoog & totaal \\
\hline redelijk & 85 & 57 & 30 & 172 \\
\hline aanzienlijk & 83 & 105 & 76 & 264 \\
\hline zeer & 43 & 60 & 99 & 202 \\
\hline totaal & 211 & 222 & 205 & 638 \\
\hline
\end{tabular}

$\chi^{2}=56.49, \mathrm{df}=4, p=.0000 ;$ tau $b=.25429$ 
Tabel 17.14:

Tevredenheid en deliberatie

\begin{tabular}{llcll}
\hline & $\begin{array}{l}\text { deliberatie } \\
\text { weinig }\end{array}$ & redelijk & veel & totaal \\
\hline revredenheid & 58 & 55 & 52 & 165 \\
aanzienlijk & 75 & 93 & 81 & 249 \\
zeer & 57 & 68 & 56 & 181 \\
totaal & 190 & 216 & 189 & 595 \\
\hline
\end{tabular}

$\chi^{2}=1.45, \mathrm{df}=4, \mathrm{p}=.8361 ;$ tau $\mathrm{b}=.01202$ 


\section{Loyalty and Satisfaction}

\section{A study into the relationship between brand loyalty and consumer satisfaction}

This summary is structured along the various phases of our research. Firstly, the problem will be elucidated. Secondly, we will present the main hypotheses of this study. Thirdly, we will describe our empirical research project and we will present the major findings. Finally, we will draw some conclusions.

\section{Problem statement}

In the past, much research has been done on each of the two concepts of brand loyalty and consumer satisfaction separately. However, little attention has been given to the relationship between the two. Studies on brand loyalty concentrated on the conceptualization and measurement of brand loyalty and the (economic and psychological) antecedents of brand loyalty. Research on consumer satisfaction focused on the factors that cause satisfaction and dissatisfaction as well as on the ways to express (dis)satisfaction. The consequences of brand satisfaction, in terms of brand loyalty, did not receive much attention. Therefore the central problem statement is:

Does consumer satisfaction explain brand loyalty and if so, how?

Based on the literature, we claim it is necessary to distinguish between two types of brand loyalty: true brand loyalty and spurious brand loyalty. True brand loyalty can be defined as:

the biased (i.e. nonrandom), behavioral response (i.e. purchase), expressed over time, by some decision making unit, with respect to one or more alternative brands out of a set of such brands, and is a function of brand commitment, which, in turn, is a result of psychological (decision making; evaluative) processes.

whereas spurious brand loyalty can be defined as:

the biased (i.e. nonrandom), behavioral response (i.e. purchase), expressed over time, by some decision making unit, with respect to one or more alternative brands out of a set of such brands, and is a function of inertia.

The commitment concept makes the difference between the two definitions. Brand commitment is a necessary condition for true brand loyalty to occur. We define brand commitment as: 
As a result of explicit and extensive decision making processes, as well as evaluative processes, a consumer becomes committed to the brand (when the brand is positively evaluated): he or she is pledged or bound to his/her brand choice. By definition, such a committed consumer is truly brand loyal when he/she buys the particular brand again. (On the other hand the non-committed consumer might just rebuy the brand without being bound to that brand.)

Brand satisfaction can be defined as:

the outcome of the subjective evaluation that the chosen alternative (the brand) meets or exceeds the expectations.

This definition is in line with the many definitions of satisfaction based on the disconfirmation paradigm that can be found in the literature. The notion that stands out in almost every definition of satisfaction is the notion of comparison, meaning that a consumer is able to compare expectations and (product) performance. Consequently, a consumer must have the motivation and the capacity to evaluate the brand relative to his/her frame of reference. This means the consumer must be able to elaborate upon the evaluation to be consciously satisfied. This view is in line with the way of reasoning in the Elaboration Likelihood Model. In that model the concepts of motivation and capacity are central in the sense that they determine the degree of elaboration. The central route (high degree of elaboration) in this model leads to a permanent attitude change; the peripheral route (low degree of elaboration) in this model leads at most to a temporary attitude change.

Sometimes, it may be very hard for consumers to generate expectations, to evaluate performance, and to compare the two as if they were independent elements. To the extent that an explicit comparison can be made between expectations and performance, the consumer is likely to be aware of the outcome of his/her evaluation and his/her satisfaction. To the extent that no explicit comparisons can be made, because of a lack of motivation or ability of the consumer to evaluate his/her brand choice, the consumer is not likely to be fully aware of his/her satisfaction. For this reason, we consider it necessary to make a distinction between manifest and latent satisfaction.

Manifest satisfaction is the outcome of the explicit subjective evaluation of the brand, which the consumer is well aware of (a kind of central route). In the case of latent satisfaction, the consumer does not realize his/her satisfaction and merely accepts the brand (a kind of peripheral route).

Now that the central concepts of our research have been defined, hypotheses about the relationship between brand loyalty and consumer satisfaction, can be formulated. 


\section{Hypotheses}

Manifest satisfaction is the result of the explicit and extensive evaluation of the brand choice, an evaluation which is well elaborated upon and the consumer is fully aware of. We assume that manifest satisfaction will be clearly related to future buying behaviour. Latent satisfaction is the result of an implicit evaluation of the brand choice, which is not elaborated upon and the consumer is not fully aware of. We assume that latent satisfaction is not so unequivocally related to future buying behaviour.

This leads to the following hypotheses:

H1: The amount of satisfaction is positively related to true brand loyalty.

H2: Manifest satisfaction is positively related to true brand loyalty.

H3: The positive relation between manifest satisfaction and true brand loyalty is stronger than the positive relation between latent satisfaction and true brand loyalty.

The last two hypotheses are based on the following assumption:

A1: The greater the amount of elaboration, the more manifest the satisfaction.

Hypothesis 1 is based on the traditional opinion that satisfaction and brand loyalty are positively related. This has already been confirmed by a number of studies, although, it is not true that every satisfied consumer will be brand loyal. Therefore, our study explicitly focuses on true brand loyalty, while most studies carried out in the past did not make the crucial difference between true brand loyalty and spurious brand loyalty. Hypothesis 2 stresses the positive relation between one type of satisfaction and one type of brand loyalty. Especially, manifest satisfaction will lead to brand commitment, which is a necessary condition for true brand loyalty.

Hypothesis 3 points out that latent satisfaction can be related also to true brand loyalty. However, the positive relation between manifest satisfaction and true brand loyalty is expected to be much stronger than the positive relation between latent satisfaction and true brand loyalty.

The assumption makes clear that we assume that those consumers who evaluate their brand choice explicitly and extensively will be manifestly satisfied. Those consumers elaborate upon their choice extensively. As stated before, the amount of actual elaboration depends on the motivation and the capacity of the consumer to elaborate upon the brand choice. In line with the Elaboration Likelihood Model motivation can be operationalized by brand choice involvement and capacity can be operationalized by brand deliberation.

In our empirical research we concentrate on the degree of true brand loyalty and the difference between manifest and latent satisfaction in order to solve our general problem statement and to test the hypotheses. 
The empirical research is based on a mail survey among Dutch consumers. The sample (838 consumers) was found to be representative for the Dutch population and for the market shares of the two products used: blank audio cassettes and hair shampoo.

The measurement instrument is based on scales validated in other research projects, and some new questions. It was revised on the basis of various pilot tests.

In order to create the subgroups needed (one group manifestly satisfied and the other latently satisfied), the sample was split based on the degree of involvement (as an indicator of the motivation of the consumer to evaluate the brand) and the degree of deliberation (as an indicator of the capacity of the consumer to evaluate the brand).

\section{Findings}

Five hundred and eighty-nine respondents have bought at least one blank audio cassette during the last six months. Whereas 809 respondents have bought hair shampoo in the last three months. In both cases about ninety-five percent of them were satisfied with the brand they bought. Of these satisfied respondents, about one third are $100 \%$ satisfied about and one fourth are $75 \%$ or less satisfied. Only $2 \%$ of the respondents indicated that they were dissatisfied with the brand they bought and a more or less similar number did not know whether they were satisfied or dissatisfied.

Thirty (audio cassettes) to forty (hair shampoo) percent indicated that they were $100 \%$ sure to buy the same brand again, the next time they had to buy it. About $30 \%$ were not so sure they would do so. These respondents indicated only a $50 \%$ chance that they would buy the same brand again.

Concerning the relationship between true brand loyalty and consumer satisfaction, we find that a direct and positive relationship exists between the amount of consumer satisfaction and true brand loyalty in general (meaning no distinction has been made between manifest satisfaction and latent satisfaction). This confirms our first hypothesis. However, as expected, the correlation is not at all perfect. Additional analyses depicted a moderator effect of the type of satisfaction (manifest of latent) on the relationship between the amount of consumer satisfaction and brand loyalty. It can be concluded that the positive relationship between manifest satisfaction and true brand loyalty is stronger than the positive relationship between latent satisfaction and true brand loyalty. Therefore, hypothesis 2 and hypothesis 3 can be confirmed.

\section{Conclusions}

The answer to our problem statement, "Does consumer satisfaction explain brand loyalty and if so, how?" is affirmative: brand satisfaction does positively affect brand loyalty. However, it appeared that it is important to differentiate between the impact of manifest satisfaction on true brand loyalty and the impact of latent satisfaction on true brand loyalty. The impact of manifest satisfaction on true brand loyalty is larger than the impact of latent satisfaction. 
The major implications of this research are that future (academic and commercial) research on the relationship between consumer satisfaction and brand loyalty should explicitely take into account the difference between on the one hand true brand loyalty and spurious brand loyalty and on the other hand manifest satisfaction and latent satisfaction. 


\section{Curriculum Vitae}

José Bloemer werd op 11 april 1961 geboren te Haaksbergen. Na het behalen van het VWO-diploma aan de Haaksbergse Scholengemeenschap in 1979, studeerde zij van 1979 tot 1983 Psychologie aan de Rijksuniversiteit Utrecht. Van 1983 tot 1986 studeerde zij Economische Psychologie aan de Katholieke Universiteit Brabant. Van 1986 tot 1987 was zij als toegevoegd onderzoekster verbonden aan de sectie Economische Psychologie van de Katholieke Universiteit Brabant. Sinds 1987 is zij universitair docente Marketing en Marktonderzoek bij de vakgroep Bedrijfseconomie van de Rijksuniversiteit Limburg. Haar wetenschappelijke interesse richt zich met name op merktrouw en tevredenheid en daarnaast reclame, consumentengedrag, direct marketing en marktonderzoek. 
Maar al te vaak wordt impliciet verondersteld dat wanneer de tevredenheid van een consument met een merk toeneemt ook de merktrouw van die consument toeneemt. Deze redenering blijkt niet altijd op te gaan omdat een paar belangrijke aspecten over het hoofd worden gezien. Deze komen in dit boek ondermeer aan de orde.

Er wordt veelal geen onderscheid gemaakt tussen ware merktrouw en herhalingsaankopen. Ware merktrouw uit zich in het herhaald kopen van het merk, gebaseerd op de binding of de commitment van de consument met het merk. Herhalingsaankopen uiten zich eveneens in het herhaald kopen van het merk, echter zonder dat hieraan een zekere binding met het merk ten grondslag ligt.

Ook wordt geen onderscheid gemaakt tussen twee soorten tevredenheid: manifeste tevredenheid en latente tevredenheid. Manifeste tevredenheid komt voort uit een uitgebreide (bewuste) evaluatie van een merk. Latente tevredenheid daarentegen is niet meer dan een impliciete acceptatie van een merk die niet gebaseerd is op een uitgebreide evaluatie van een merk. Met behulp van empirisch onderzoek wordt aangetoond dat vooral manifeste tevredenheid tot ware merktrouw leidt en dat dat in veel mindere mate geldt voor latente tevredenheid. Dit betekent dat het niet verstandig is, om 'willekeurig' de mate van tevredenheid van een de consument te stimuleren, wanneer een aanbieder ware merktrouw wil bevorderen. Consumenten zullen immers veel minder snel geneigd zijn van merk te wisselen wanneer zij manifest tevreden zijn dan wanneer zij latent tevreden zijn. Aanbieders die streven naar ware merktrouw zullen er dus vooral voor moeten zorgen dat de consumenten van zowel produkten als diensten manifest tevreden zijn.

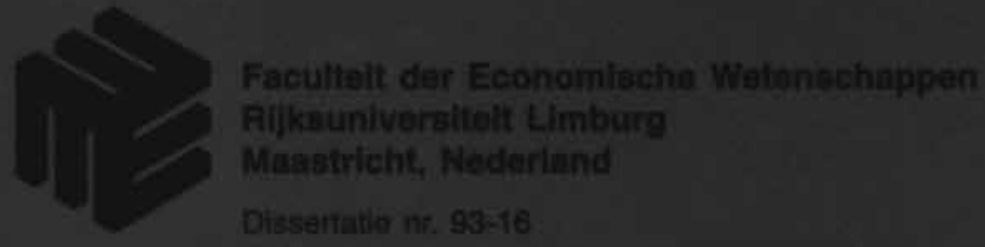

